Almir Teubl Sanches

\title{
A questão de terras no início da República: o Registro Torrens e sua (in)aplicação
}

\author{
Dissertação apresentada como \\ requisito parcial à obtenção do grau \\ de Mestre em Teoria Geral e \\ Filosofia do Direito da Faculdade \\ de Direito da Universidade de São \\ Paulo, sob a orientação do Prof. Dr. \\ José Reinaldo de Lima Lopes.
}

Faculdade de Direito

São Paulo 
“Ah, quem escreverá a história do que poderia ter sido? Será essa, se alguém escrever, A verdadeira história da humanidade." Álvaro de Campos 
Aos meus pais que, com muito amor e delicadeza, me incutiram a sede de saber.

A Melina que, com muito amore delicadeza, me ensinou a aplacar a dor que muitas vezes esta sede causa. 


\section{Índice.}

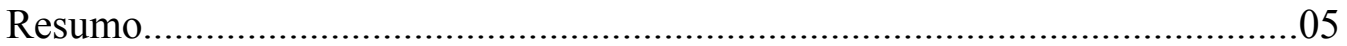

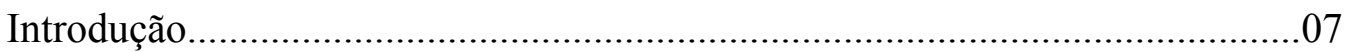

Dimensionamento do estado atual da questão.......................................................09

Cap. 1 - Um legado imperial - a questão de terras no Império.............................22

Cap. 2 - O problema do crédito agrícola na segunda metade do Império...........28

Cap. 3 - O Governo Provisório e a tentativa de reforma liberal..........................55

Cap. 4 - O Registro Torrens no direito brasileiro................................................68

Cap. 5 - A reforma econômica de Rui Barbosa....................................................89

Cap. 6 - A Constituição de 1891 e a questão de terras........................................106

Cap. 7 - Políticas estaduais de terras...............................................................132

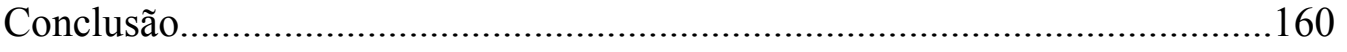

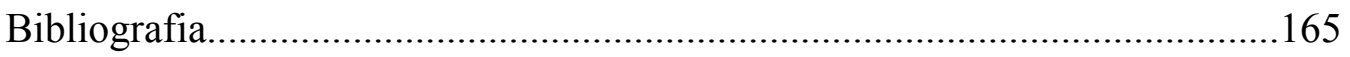




\section{Resumo.}

O presente trabalho teve como objetivo mostrar como o cenário socioeconômico brasileiro da segunda metade do séc. XIX clamava pela organização e modernização do sistema registral imobiliário, a fim de que a terra se inserisse definitivamente na esfera de circulação de capital, passando a ter valor de mercado e a substituir a propriedade escrava na garantia do financiamento agrícola.

Focando-se especificamente na questão de terras e na tentativa de instituição do Registro Torrens, esta pesquisa teve ainda por objetivo demonstrar como as tentativas progressistas de reforma, surgidas no início da Republica graças a um vácuo político ocasionado pela fragilidade da aliança republicana, foram barradas pelo processo constituinte de 1891, liderado por forças políticas federalistas.

Além disso, buscou-se aqui também demonstrar como o reaproveitamento e a distorção das normas da Lei de Terras pelos governos republicanos estaduais possibilitaram uma política de terras liberalizante, cujos beneficiários eram cuidadosamente selecionados, de acordo com seu status e com seu alinhamento com o poder regional. 


\begin{abstract}
.
The present work had the goal of showing in which manner the brazilian socialeconomic setting in the second half of the XIXth century clamored for the organization and modernization of the real-state registry system, in order to definitively insert land into the sphere of circulating assets, acquire market value, and replace slave property as guarantees in agricultural financing.

Focusing specifically in the matter of land an in the attempt to institute the Torrens Registry, this research also aimed to demonstrate how progressivist attempts of reform, born in the beginning of the Republic due to a political vacuum occasioned by the fragility of the Republican Alliance, were barred by the Constituent process of 1891, led by federalist political forces.

Furthermore, it was here sought to demonstrate as well how the availing and distortion of Lei de Terras' norms by republican state governments made possible a land liberalizing policy, whose beneficiaries were carefully selected, in accordance with their status and with their alignment with regional power.
\end{abstract}




\section{Introdução.}

A presente pesquisa pretende analisar a política de terras no nascimento do Brasil republicano, focando-se no registro da propriedade imobiliária e, especialmente, na utilização do Registro Torrens.

Para tanto, antes de adentrar no estudo do regime republicano, faz-se necessária uma breve contextualização da situação da questão de terras e de outras a ela relacionadas nos últimos anos do Império. A isso serão dedicados os dois primeiros capítulos.

O primeiro capítulo cuidará propriamente da questão de terras, esboçando o processo legislativo da Lei de Terras de 1850, bem como as causas a que se deveu a muito pequena efetividade de sua aplicação. Ainda no primeiro capítulo, veremos como se encontrava a situação da demarcação de terras nos anos finais do Império.

O segundo capítulo, por sua vez, cuidará de questões relacionadas à terra, especialmente do grave problema de escassez de crédito agrícola que perpassou a segunda metade do século XIX. Veremos como a pequena oferta de crédito agrícola deveu-se, notadamente, à crise de numerário decorrente da política econômica restritiva adotada pelo governo frente às crises financeiras dos anos 1860 e 1870 e ao acentuado endividamento público, causado especialmente pela Guerra do Paraguai.

Em seguida, e agora já adentrando no estudo do regime republicano, o terceiro capítulo se dedicará a entender a conjuntura em que se deu a ascensão da República. Como veremos, a fragilidade da aliança do movimento republicano, bem como a ausência de um projeto consensual de governo, possibilitou a formação de um vácuo político, no qual classes progressistas até então alijadas do poder viram a oportunidade de implementar suas reformas liberais.

É nesse contexto que se dará a tentativa de reforma liberal de Rui Barbosa, que também será ali estudada. Dentro dessa tentativa de reforma, Rui Barbosa reservou um papel todo especial ao crédito hipotecário, entendendo que seu aprimoramento e alargamento sanariam boa parte dos problemas herdados do Império. Era necessária, entretanto, uma profunda reforma do sistema registral brasileiro, para que a terra se inserisse definitivamente na esfera de circulação de capital e, assim, passasse a ser uma garantia adequada aos empréstimos agrícolas. E, no projeto de Rui Barbosa, essa reforma registral caberia ao Registro Torrens. 
O capítulo quarto se dedicará ao estudo do decreto $\mathrm{n}^{\circ}$ 451-B e de sua regulamentação, analisando a conformação jurídica que o Governo Provisório atribuiu ao sistema Torrens de registro e observando como este realmente se prestava, no plano jurídico, a garantir os ideais de segurança e certeza dos títulos de propriedade imobiliária, dos quais necessitava a tentativa de reforma de Rui Barbosa.

No capítulo quinto, veremos outro aspecto econômico da reforma de Rui Barbosa e como os excessos de sua política emissionista acabaram por fomentar o ambiente especulativo que vinha se desenvolvendo desde os últimos anos do Império. Ainda nesse capítulo, se cogitará da hipótese de o vertiginoso crescimento do crédito hipotecário ter influenciado na votação do Congresso Constituinte, por ter feito com que se relegasse a um segundo plano a reforma registral imobiliária.

O processo constituinte, aliás, será objeto de estudo do sexto capítulo, vendo-se como a tentativa de reforma do Governo Provisório foi em boa parte minada pela emenda que deu nova redação ao dispositivo que previa que a propriedade das terras devolutas seria da União, passando a atribuí-la aos Estados.

Por fim, veremos como, após a Constituição de 1891 e a passagem das terras devolutas aos Estados, as políticas de terra estaduais foram em boa parte responsáveis pela deterioração do patrimônio imobiliário público, com medidas liberalizantes que tinham destinatários cuidadosamente selecionados. 


\section{Dimensionamento do estado atual da questão.}

Neste primeiro momento será realizada uma breve análise historiográfica sobre a questão agrária no Brasil do final do oitocentos, valendo-se dos debates políticos produzidos a partir dos anos 60 do século XX no Brasil ${ }^{1}$. Cumpre destacar que, nesse tema, a bibliografia é bastante vasta ao tratar do Império, especialmente no que se refere à Lei de Terras de 1850, e não tão abundante ao tratar da República Velha. Há certa justificativa para isso: a lei de 1850 é considerada um verdadeiro marco de mudança, sendo a política de terras da República Velha considerada mera continuação desta lei. Acredito que tal entendimento seja apenas parcialmente acertado, como pretendo mostrar durante a pesquisa. Dito isto, passemos então à análise historiográfica.

Um dos primeiros autores a tratar detidamente da questão de terras no Brasil é Nelson Werneck Sodré. Inclusive, pode-se considerar Sodré um dos principais fundadores, senão o principal, de uma discussão que viria atravessar pelo menos por duas décadas os debates acadêmicos acerca da questão de terras. Esta discussão giraria em torno do caráter feudal do modo de produção brasileiro.

Com efeito, foi Sodré quem primeiramente defendeu que, durante o regime escravista e, mais do que isso, por meio deste regime, teria se implantado no Brasil um sistema de produção e de distribuição de terras que em muito se assemelhava ao feudalismo. Desde então, por não haver ocorrido uma Revolução Democrático-Burguesa como se verifica em outros países de herança feudal, o Brasil ainda seria vítima de seu passado feudal. Desta maneira, o autor buscava nessa herança feudal a explicação para toda a história do subdesenvolvimento do Brasil, sendo seus efeitos sentidos até os anos 1950, época em que escrevia.

Para Sodré, nem a abolição da escravidão, nem a proclamação da República, nem mesmo o surto industrial que ocorreu a partir dos anos 30, equivaleriam às revoluções burguesas ocorridas na Europa, o que de certa maneira deixava o Brasil às margens da história. A principal razão disso é que nenhuma dessas mudanças foi capaz de alterar

\footnotetext{
${ }^{1}$ Além dos livros aqui citados, foi de grande valia para a elaboração deste capítulo a consulta ao artigo de Ângela de Castro Gomes e Marieta de Moraes Ferreira intitulado Primeira República: um balanço historiográfico (1989).
} 
fundamentalmente aquilo que o autor considera um dos principais fatores de conformação sócio-econômica: a forma de apropriação da terra.

A extinção da escravidão teria, assim, aberto caminho para um outro tipo de exploração do trabalho, a semi-servidão. Geograficamente, o espaço de exploração do trabalho semi-servil coincide quase que completamente às antigas regiões escravocatas. É bem verdade, e isso o admite Sodré, que restava aos ex-escravos a opção dos espaços urbanos. Nestes espaços, porém, nada os esperava além de uma condição de marginalização, que acabaria por mantê-los excluídos e irrelevantes ao sistema produtivo.

Mesmo a imigração dos trabalhadores europeus não teria sido capaz de transformar as relações de trabalho, pois estes trabalhadores tiveram de se adequar a um sistema no qual a propriedade latifundiária ditava as regras de produção. Desta forma, é interessante notar que, para o autor, ao invés de constituir fator de transformação social, a vinda dos imigrantes serviu justamente para o contrário, a perpetuação do sistema feudal baseado no latifúndio.

Quanto às pequenas apropriações territoriais de espaços vazios, Sodré as julga como um agrupamento desordenado de ações que, encaradas como um todo, permaneceu inexpressível e irrelevante em relação ao mercado. Assim, não se tratava da expansão de uma fronteira móvel, mas antes de ações isoladas e que não chegavam a transformar o mercado produtivo e as relações de trabalho.

Outro aspecto interessante da obra de Sodré é a categoria de nação, associada a um caráter evolutivo e processual da etapa burguesa do processo revolucionário brasileiro. O historiador igualmente apontava para o papel do latifúndio e do imperialismo como obstáculos ao desenvolvimento econômico nacional. Daí as polêmicas provocadas dentro do Partido Comunista Brasileiro, ao qual ele era vinculado, ao advogar a tese de que frações da burguesia poderiam se situar no campo revolucionário de um cenário antiimperialista e democrático, na medida em que se projetava um desenvolvimento capitalista autônomo no Brasil.

A concepção teórica de Sodré do Brasil como um sistema semifeudal de produção lhe rendeu inúmeros adeptos. Dentre eles, talvez o que mais se destaque seja Alberto Passos 
Guimarães, que viria a aprofundar esta idéia, desenvolvendo-a de forma mais complexa e completa.

E o fez em seu livro Quatro séculos de latifúndio, obra que pretendia mostrar os efeitos perniciosos da concentração fundiária no país. Para tanto, buscava encontrar as origens históricas desta concentração. Isso tudo tendo como base a idéia legada por Sodré de feudalismo, ou melhor, semifeudalismo brasileiro.

É importante lembrar que quando Guimarães escreveu o livro, em 1963, havia uma onda de otimismo gerada pela promessa de Reforma Agrária do Governo João Goulart. Com efeito, o autor considerava que a única maneira de se estabelecer um capitalismo em bases nacionais que superasse o estado feudal brasileiro seria a realização de uma reforma agrária democrática, a qual teria um duplo poder de destruição: (i) acabar com "as relações semicoloniais de dependência ao imperalismo" e (ii) romper com "os vínculos semifeudais de subordinação ao poder extraeconômico, político e jurídico da classe latifundiária” (GUIMARÃES, 1977:38).

Apesar das semelhanças entre os trabalhos de Sodré e Guimarães, uma diferença metodológica fundamental se faz notar entre eles. Ainda que Guimarães valha-se da idéia de semifeudalismo brasileiro, ele não se contenta em analisar a relação escravo/senhor, como o faz Sodré, mas sim a desenvolve atentando mais aos setores sociais estranhos a esta relação, mostrando como, mesmo nestes setores, toda a produção seria tributária de um modelo feudal.

É neste sentido que Guimarães volta seus olhos ao pequeno posseiro, encarado como símbolo de resistência face ao poder dos senhores latifundiários. Considera, assim, a posse como "a arma estratégica de maior alcance e maior eficácia na batalha secular contra o monopólio da terra" (GUIMARÃES, 1977:113).

Frustradas as esperanças de reforma agrária com o golpe militar de 1964, os intelectuais viram a necessidade de rever seus pressupostos teóricos. Ao contrário do que tais pressupostos indicavam, o capitalismo no Brasil encontrava-se em plena expansão, não havendo amarras feudais que o impedisse de se desenvolver. Prova maior disso é que o Golpe havia sido apoiado pela burguesia, nacional e estrangeira, que há muito já se haviam aliado. 
Neste contexto que ganha força o pensamento de Caio Prado Júnior, que insistia em negar características feudais ou semifeudais no sistema de produção brasileiro. Em seu livro Revolução Brasileira, de 1966, o autor aponta alguns erros teóricos daqueles que entendiam o Brasil como um sistema feudal. Sua principal crítica seria que eles partiam de um conceito previamente formulado e depois olhavam para a realidade, buscando encaixála neste conceito prévio. No fundo, a crítica de Caio Prado, que por sinal ele dirigiu não só aos defensores da "tese feudal", mas também a boa parte da tradição intelectual marxista, seria que se havia caído em um idealismo, no qual a formulação de idéias antecede o exame da realidade e se sobrepõe a ele.

Assim, Caio Prado apontaria como um dos principais erros dos defensores da "tese feudal" o transplante descuidado de modelos clássicos de interpretação histórica para a reflexão sobre a sociedade brasileira. Caio Prado entendia que, no Brasil dos anos 60, eram relações econômicas capitalistas, que prendiam os trabalhadores à terra, e não relações feudais de poder de fatores extra econômicos.

Em suma, para Caio Prado a teoria da revolução brasileira deveria centrar-se na luta antiimperialista, sem esquecer a vinculação estreita entre os interesses das grandes potências e a burguesia nacional.

Mas, se o Brasil nunca havia sido um sistema feudal, como então o entendia Caio Prado? Ele entendia que, desde suas origens coloniais, o Brasil havia se desenvolvido dentro de relações capitalistas. Embora entendesse que, rigorosamente encarado, o termo capitalismo era inadequado, acreditava em contrapartida que, em comparação a um sistema feudal, o país apresentava bem mais fortemente características capitalistas. Já em 1942, com seu livro Formação do Brasil Contemporâneo, Caio Prado viu no sistema colonial adotado no Brasil uma empresa comercial, com fortes traços capitalistas, portanto, que visava a exploração territorial e econômica da colônia para o enriquecimento da metrópole européia. Desta forma, inserindo-a no plano internacional, indubitavelmente capitalista, também a colônia passaria a ser encarada como uma engrenagem no sistema capitalista.

Com efeito, a grande diferença metodológica existente entre os trabalhos de, de um lado, Caio Prado Júnior, e de outro, Sodré e Guimarães, é que enquanto estes últimos pareciam querer entender o Brasil isolando-o de todo o cenário internacional, Caio Prado 
preocupava-se justamente com o contrário, isto é, entendê-lo a partir de seus vínculos externos. Pode-se dizer que desta diferença metodológica decorre boa parte das outras diferenças teóricas desses trabalhos.

É justamente por se voltar para as relações externas brasileiras que Caio Prado consegue entender grandes empresas monocultoras, trabalhadas por escravos, como instrumentos que buscavam fazer com que o Brasil pudesse servir aos interesses comerciais europeus. Em última análise, tanto o trabalho escravo quanto o sistema latifundiário seriam instrumentos capitalistas a serviço da metrópole. O autor via na escravidão e no latifúndio obstáculos ao desenvolvimento socioeconômico do homem livre, obstáculos estes que se mostravam desejáveis aos interesses europeus Ambos atendiam duplamente a estes interesses, pois, não só sufocavam o surgimento de um mercado interno que fizesse frente às demandas européias como ainda focavam a produção numa monocultura que atendesse a essa demanda.

Formava-se, assim, um círculo vicioso no qual a propriedade latifundiária, ao invés de obstáculo à expansão capitalista, era fator de fortalecimento desse sistema econômico, ao mesmo tempo em que esse sistema, satisfeito com a dependência externa brasileira, protegia o latifúndio que gerava tal dependência, dificultando o acesso a terra àqueles que não fossem latifundiários.

Apesar de todas as diferenças até aqui colocadas, não se pode deixar de notar, entretanto, um ponto no qual os trabalhos de Caio Prado chegam a uma conclusão muito próxima daquela a que chegaram Guimarães e Sodré em suas pesquisas. Para todos eles, embora a crise do regime escravista tenha sido uma ameaça concreta ao poder dos grandes proprietários de terra, sua superação através do processo de imigração européia não foi suficiente para que o acesso à propriedade de terra deixasse de ser dificultado, o que fez com que os imigrantes se mantivessem muitas vezes em condições próximas ao regime servil.

No entanto, mesmo nesse ponto pode-se encontrar uma importante diferença entre os pensamentos de Caio Prado e dos outros dois autores. Caio Prado parece mais propenso a aceitar que, embora não tenha acabado totalmente com os obstáculos do acesso a terra, o 
processo imigracionista, ao permitir a expansão da pequena propriedade, rompeu com os “primitivos quadros econômicos e sociais do país” (PRADO JÚNIOR, 1972:249).

Aceitando e desenvolvendo a visão de Caio Prado de capitalismo na conformação histórica da sociedade brasileira Maria Sylvia de Carvalho Franco defende em 1964, sua tese de doutorado. Intitulada Homens Livres na Ordem Escravocata, a obra procuraria analisar a vida dos homens livres pobres durante o século XIX, com um enfoque específico na região de Guaratinguetá.

Alguns aspectos metodológicos da pesquisa de Carvalho Franco merecem ser destacados. Em primeiro lugar, este corte espacial realizado pela autora, enfocando a realidade histórica especifica de uma região antecipa, em certa medida, uma tendência que viria a se tornar dominante na historiografia nacional algumas décadas depois, entre a segunda metade dos anos 80 até os dias de hoje. Essa tendência é a opção dos historiadores pelos estudos regionais ou temáticos, em detrimento das explicações gerais. Acreditamos que, nesse sentido, Carvalho Franco foi uma das principais precursoras desta tendência.

No entanto, o caráter precursor dessa pesquisa deve ser relativizado, pois há uma diferença fundamental entre ela e os trabalhos realizados algumas décadas depois: enquanto estes buscavam mostrar as peculiaridades regionais, contrapondo-as às generalizações das grandes teorias explicativas, o trabalho de Carvalho Franco busca partir de um exemplo concreto, os homens livres da região de Guaratinguetá, para dar uma explicação mais ampla, mais geral da sociedade brasileira.

Um outro aspecto metodológico a ser ressaltado na pesquisa de Carvalho Franco é a utilização de uma fonte bastante original: os processos crimes. Em suas próprias palavras, com a utilização deste tipo de fonte a autora buscou entender "o papel da violência enquanto uma forma rotinizada de ajustamento nas relações de vizinhança” (FRANCO, 1983:28).

Por fim, mais um aspecto metodológico parece nos interessar. Valendo-se de Weber, a autora parte da construção de tipos ideais, buscando explicar as relações sociais a partir destes tipos. Assim, para reconstruir as bases em que se dava a dominação pessoal entre grandes e pequenos proprietários, vale-se das figuras do sitiante e do fazendeiro. A relação de compadrio entre eles marca-se pela ausência de conflitos significativos. Isto por 
que o sistema de controle era tão forte que impedia que as tensões rompessem o equilíbrio estabelecido. Assim, uma situação em que o conflito poderia surgir, como quando o sitiante via sua posse esbulhada pelo grande proprietário local, resolvia-se normalmente com a retirada pacífica do sitiante para novas áreas, ainda não alcançadas pela grande propriedade latifundiária.

É desta maneira que, para a autora, a grande propriedade mercantil impedia o homem livre pobre de qualquer atuação autônoma, destinando-o a acomodação ou a revolta individual infrutífera. Enfim, condenava este homem a uma existência sem razão.

Prosseguindo na análise do debate acadêmico, nota-se que, em fins da década de 70 e início da de 80 , este debate voltou-se fundamentalmente a temas relacionados à escravidão, deixando-se um pouco de lado a questão da propriedade da terra nos estudos então produzidos.

No entanto, a hegemonia do tema da escravidão não foi suficiente para impedir alguns autores de continuar debatendo sobre a questão da propriedade da terra. Como exemplo, vemos que, ainda na década de 70, em sua obra intitulada Da Senzala à Colônia, Emília Viotti da Costa analisava a "marcha avassaladora do latifúndio", no qual ela atenta para a maneira como os grandes latifúndios avançaram sobre as pequenas propriedades e como esse avanço fundava-se, ao lado do uso da força, em um mecanismo jurídico de apropriação da terra. A autora nota ainda que, apesar de constituírem exceções, não faltaram pequenos proprietários que se insurgiram contra essa dominação dos latifúndios sobre suas propriedades, assinalando que o processo de desapropriação daqueles por estes não se deu sem conflitos e embates. Neste ponto podemos notar uma discordância da autora com relação à obra de Carvalho Franco, uma vez que esta entendia que, pelo equilíbrio das relações de poder, os conflitos quase nunca chegavam a emergir, sufocados pela dominação.

Quanto aos estudos relacionados à transição do trabalho escravo para o trabalho livre, um dos principais é o realizado por José de Souza Martins, em especial em seu clássico O Cativeiro da Terra. Escrito em 1979, o principal enfoque do livro é a reconstrução histórica do regime de colonato, surgido com a crise escravista. Martins buscou mostrar como tal regime se caracterizava justamente por não se tratar de uma 
relação capitalista de produção. Ainda que considere que não existe um modo capitalista de produção brasileiro, o autor entende que o Brasil, bem como toda a América Latina, deve ser entendido como uma economia inserida em um "capitalismo comercial".

Assim, o que se poderia chamar de capitalismo brasileiro - ou latino-americano não se traduziria necessariamente como relações capitalistas de produção. Isto por que, em seu processo de expansão, o capitalismo não só conseguiria criar novas formas de produção, como seria ainda capaz de reconfigurar antigas formas de produção.

E é justamente dessa última maneira, isto é, da reconfiguração de novas formas de produção, que Martins entende a emergência do trabalho livre no Brasil. Para ele, haveria nesta emergência uma contradição: a transformação das relações de produção teria se dado justamente para que fosse preservado o modelo colonial de nossa economia, ou seja, justamente para que se salvasse o padrão de realização do capitalismo no Brasil, que se caracterizava pela subordinação da produção ao comércio. Por isso, a classificação do Brasil como um país de capitalismo comercial.

É interessante notar como Martins demonstra essa manutenção do padrão de realização do capitalismo no Brasil através do tratamento que ele dá ao conceito de renda capitalizada e sua transformação com a crise do escravismo. Por renda capitalizada deve-se entender aquela utilizada como garantia na obtenção de crédito para financiar a produção. Para o autor, com a crise do escravismo e posterior abolição da escravidão teria ocorrido uma transformação da renda capitalizada, deixando essa de se identificar com a propriedade de escravos para passar a sê-lo com a propriedade territorial.

É neste sentido que a Lei de Terras de 1850 adquire um significado especial, pois, ao proibir outro meio de acesso à terra que não a compra, tal lei tornou possível que a terra passasse a ser considerada como fonte de renda capitalista. Assim, o capital antes investido em escravos poderia ser investido em terras, de maneira que, com essa substituição, mantinham-se os padrões de acumulação dos fazendeiros de café, não mais agora consubstanciados na propriedade dos escravos, mas sim na da terra. Justifica-se, desta maneira, o título da obra de Martins - $O$ Cativeiro da Terra - pela sua célebre frase de que "num regime de terras livres, o trabalho tinha que ser cativo, num regime de trabalho livre, a terra tinha que ser cativa" (MARTINS, 1986:32). 
Como já dito anteriormente, a partir da segunda metade da década de 80 uma nova leva de autores deixaria de buscar grandes esquemas explicativos da formação histórica da sociedade brasileira, gerando uma verdadeira revolução metodológica ao adotarem em suas pesquisas temas específicos, analisados sobre cortes regionais. Deixava-se de lado o simplismo no qual muitos dos grandes esquemas interpretativos caíam, para se ressaltar a complexidade da formação histórica de nosso país. A produção acadêmica ganhou e ganha, nesse período, numerosos e valiosos trabalhos, sendo impossível citar todos que aqueles que contribuíram para confirmar ou relativizar argumentos que antes dificilmente poderiam ser verificados.

Neste mesmo contexto podem ser apontados diversos brasilianistas cujos trabalhos merecem destaque. Dentre eles, Waren Dean, James Holston, Peter Eisenberg. Seus trabalhos destacam-se pela análise minuciosa das fontes, em especial cartórios e arquivos locais, fazendo verificações empíricas das explicações sobre aquilo que pretenderam estudar.

Dentre estas contribuições, uma em especial será bastante cara a esta pesquisa. Trata-se do trabalho realizado por James Holston, originalmente intitulado The Misrule of Law: Land and Usurpation in Brazil, sendo traduzido posteriormente como Legalizando o Ilegal: Propriedade e Usurpação no Brasil.

A pesquisa de Holston gira em torno de uma questão inicial: como se pode entender o direito se o sistema jurídico que, por princípio, deveria objetivar resolver conflitos mostra-se como "um meio de perpetuar e obscurecer as disputas ao invés de resolvê-las?" (HOLSTON, 1993:68).

Para refletir sobre essa questão o autor faz uma análise histórica do tratamento legal dispensado à propriedade de terra. Chama a atenção a metodologia empregada por Holston que, para tal análise, foca-se em um caso específico que o permite reconstruir boa parte da história da propriedade imóvel brasileira.

O caso tratado por Holston é o da propriedade de terra no Jardim das Camélias, região periférica da cidade de São Paulo, localizada às margens do Rio Tietê. A história dessa região é tão complexa que mesmo Holston, que passou dois anos (entre 1987 e 1990) debruçado sobre ela, admite que "frente à sua complexidade sem limites, não posso afirmar 
que o entendo por inteiro, tampouco seria prudente dirimir de erros e distorções a análise de seus contornos" expostos (HOLSTON, 1993:84).

Após remontar toda a história das infindáveis disputas pela propriedade da região, abordando diversas transferências realizadas sobre títulos de propriedade, cujas origens são, quando pouco, duvidosas, o autor conclui mostrando como por trás das irresoluções cuidadosamente orquestradas, as leis de terras incentivaram os conflitos a respeito delas. "No decorrer deste processo, práticas ilegais produzem leis, soluções extralegais são incorporadas no processo judicial e a lei é confirmada como um canal de desordem estratégica". Para o autor, é assim, por meio da desordem estratégica, que a lei assegura a manutenção dos privilégios daqueles que possuem poderes extralegais de manipulação da política, da burocracia, enfim, da própria história. Por fim, diga-se, a irresolução jurídica acaba por se mostrar, em especial no caso de terras brasileiro, como um "meio de dominação efetivo, embora perverso" (HOLSTON, 1993:87).

Dentre outros brasilianistas que também realizaram pesquisas quanto à questão de terra, ressalte-se o trabalho de Warren Dean. Em seu Rio Claro: um sistema brasileiro de grande lavoura, o autor examinou a influência causada pela expansão da cafeicultura na região, analisando ainda o surgimento da especulação com a terra, valendo-se da pesquisa dos Registros Paroquiais de Terra. Sua pesquisa conclui que a origem do sistema das grandes lavouras em Rio Claro foi "a usurpação da terra e a eliminação ou marginalização dos lavradores existentes, por um grupo de pessoas que tinham acumulado capital nos negócios de exportação agrícola à época da colônia” (DEAN, 1977:183).

Num outro trabalho, Dean buscaria, por meio da análise da Lei de Terras, demonstrar o porquê de sua ineficácia e da incapacidade do governo imperial em proceder à discriminação das terras públicas das privadas (DEAN, 1977).

Dentre as relativizações realizadas graças a esses cortes regionais e temáticos, vemos a valorização do papel do homem livre na sociedade escravocata, sendo a partir de então considerado co-responsável pela construção do mercado interno brasileiro e pela inovação na produção agrícola.

Julgando que, se por um lado as novas pesquisas regionais trouxeram um aprofundamento da complexidade do universo rural brasileiro, por outro, estas mesmas 
pesquisas marginalizaram a discussão sobre a dinâmica da luta pela posse da terra, Márcia Maria Menendes Motta apresenta seu trabalho Nas Fronteiras do Poder, buscando reavivar o debate sobre as disputas pelo direito a terra no século XIX, analisando os conflitos de terra e a legislação agrária produzida no período. Motta acredita que a consagração acadêmica da tese de Caio Prado, levou ao esquecimento de importantes elementos dos conflitos agrários que eram apontados por Alberto Passos Guimarães.

A autora toma como pressuposto metodológico as idéias extraídas da obra do historiador inglês Thompson, que, ao ressaltar o papel decisivo da cultura, buscou uma aproximação crescente com as contribuições da antropologia, no intuito de compreender o passado para além dos elementos de natureza sócio-econômica. Assim, a autora entende que há uma tradição cultural que explica quais são os elementos através dos quais os homens legitimam o acesso a terra.

Assim, investigando concepções de justiça e de embates que fundamentaram a luta pela terra no oitocentos, Motta coloca-se em forte contraposição com as afirmações consolidadas a partir da obra de José de Souza Martins. Ela entende que grande parte dos estudos realizados na questão territorial brasileira tendeu a se preocupar fundamentalmente com os resultados dos territórios apropriados, e do que nele se produzia, sem quase nada indagarem sobre as diversas formas de acesso à terra, de legitimação do direito ao território ocupado e seus múltiplos e complexos desdobramentos. Desta forma, a autora insurge-se contra os estudos que partiram do pressuposto de que a Lei de terras viera tão somente para assegurar os interesses dos grandes proprietários. Para ela, importa ressaltar que a Lei de Terras consagrava a propriedade privada, impedindo o acesso a terra por outros meios que não sua compra.

Motta atribui parte da culpa pela incapacidade de uma análise adequada dos conflitos agrários do século XIX, à dificuldade da fazer perguntas a fontes produzidas no âmbito da justiça, pois, ao se considerar que os homens pobres e livres "não tinham razão de ser", tornou-se difícil compreender as possibilidades de investigação dos processos cíveis de embargo, despejo e de medição de terras.

No entanto, parece haver certo exagero da autora ao afirmar que a Lei de Terras de 1850 permitia "uma possibilidade de democratizar o acesso à terra" (MOTTA, 
1998:142). É interessante que os dados coletados pela própria autora mostram o contrário, isto é, apenas uma minoria de pequenos posseiros conseguiu legalizar suas terras e houve uma substancial concentração de propriedades através da transferência de terras devolutas para as mãos dos grandes fazendeiros. Isto não compromete de maneira alguma a importância da pesquisa, que é retomar uma visão problematizante do domínio da lei como componente da dinâmica dos conflitos sociais.

Outro trabalho recente que merece destaque é Terra Prometida: Uma História da Questão Agrária no Brasil, de autoria de Maria Yedda Linhares e Francisco Carlos Teixeira da Silva. Trata-se de um estudo bastante inspirado na linha de pesquisa desenvolvida na França por Marc Bloch, na qual o método comparativo é bastante valorizado e as questões históricas são tratadas dentro de um panorama de longa duração. Assim, antes de adentrar à história da questão agrária no Brasil, os autores dão uma visão geral da história agrária européia entre os sécs. XVII e XIX, expondo modelos explicativos da questão agrária, e tentando adaptá-los ao contexto latino-americano.

Por fim, gostaria de dar destaque especial ao trabalho de uma pesquisadora. Ao iniciar essa revisão bibliográfica atentei para o fato de que grande parte dos estudos sobre a questão territorial no Brasil se concentra, principalmente, no período colonial com a questão das sesmarias e no período imperial com a Lei de Terras de 1850. Em uma menor medida vê-se que alguns estudos que analisam a questão de terras a partir do início da Era Vargas, passando pelo Estatuto da Terra. O trabalho de Lígia Maria Osório Silva merece destaque não só por sua qualidade, como também por excepcionar esta rarefação, tratando da questão de terras durante a República Velha.

Em sua tese de doutoramento em Ciências Sociais, denominada A Lei da Terra Um Estudo sobre a História da Propriedade da Terra no Brasil, a autora aborda desde o período colonial até o fim da República Velha, procurando demonstrar "o processo de constituição da propriedade privada da terra no Brasil, caracterizado pela passagem das terras do domínio régio e, depois, do domínio público para o domínio privado" (1990:434). Além disso, a mesma autora publicou outro trabalho também de grande interesse para o presente estudo, chamado A Apropriação Territorial na Primeira República. Dedicando boa atenção ao período imediatamente seguinte à Proclamação da República, com análise 
da política de terras do Governo Provisório, este trabalho será de grande valia para esta pesquisa. 


\section{Cap. 1 - Um legado imperial - a questão de terras no Império.}

Para que se possa dimensionar as continuidades e rupturas que o governo republicano promoveu nos registros imobiliários, parece ser fundamental uma breve reconstrução da política de terras implementada pelo governo imperial. Dessa forma, imprescindível alguma remissão à Lei de Terras de 1850, verdadeiro marco histórico na política nacional de terras.

Evitando, entretanto, desvirtuar seu objeto de estudo, esta pesquisa não se aprofundará na análise da Lei de Terras, tantas vezes estudada e debatida. Este capítulo abordará a Lei de Terras sem pretender exaurir seu estudo, contentando-se em tocá-la apenas naquilo que mais intimamente se relacione à política de terras republicana, seja para contrastá-la, seja para reproduzi-la.

\subsection{Distorções entre o projeto de lei de 1843 e a Lei de Terras de 1850.}

Embora tenha se originado de um projeto de lei de junho de $1843^{2}$, a Lei de Terras amargou um engavetamento de mais de meia década no Senado Federal ${ }^{3}$. Quando da sua aprovação, em 1850, a lei se distanciava em muitos pontos do projeto que a impulsionara. O projeto de lei de 1843 , entre outras questões ${ }^{4}$, tratava, ao lado da questão

\footnotetext{
${ }^{2}$ Deixada de lado em razão das crises políticas da década de 1830, a questão da regularização de terras seria retomada apenas em 1842. E tal retomada se deu através de uma solicitação do ministro do Império Candido José de Araújo Viana. O ministro solicitou a elaboração de propostas concernentes à questão de terras à Seção dos Negócios do Império do então restaurado Conselho de Estado. Em junho de 1843, a proposta emanada da Seção dos Negócios do Império do Conselho de Estado, de autoria de Bernardo Pereira de Vasconcelos e José Cesário de Miranda Ribeiro, foi apresentada, ligeiramente modificada, como projeto de lei ao julgamento dos deputados.

${ }^{3}$ Após acirrados debates na Câmara, o projeto acabou sendo aprovado. Permaneceu, no entanto, engavetado no Senado durante os anos de gabinetes liberais. Além do caráter ainda não tão urgente do problema da mãode-obra, esse engavetamento pode ser atribuído ao receio liberal em apoiar medidas centralizadoras que reforçassem a autoridade imperial, o que, de certa forma, decorreria da regulamentação territorial (SILVA: 1990:137-138). Com isso, apenas após a ascensão de um novo gabinete conservador, em 1848, seria dada continuidade à discussão do projeto, o qual, revisto e reformulado, se reapresentaria à Câmara e ao Senado.

${ }^{4}$ Além desses pontos, o projeto de lei proibia a concessão de novas sesmarias e encarregava o Governo Imperial da venda de terras devolutas, em porções nunca inferiores a um quarto de légua quadrada. Os recursos arrecadados com os impostos criados e as terras vendidas serviriam para financiar a vinda de colonos livres. Outro ponto importante do projeto é a proibição dos imigrantes de comprar, arrendar, aforar ou obter por qualquer outro modo o uso da terra, por três anos contados de sua chegada.

Muito se fala na inspiração desse projeto na teoria de Wakefield. Alguns deputados chegam mesmo a citá-lo nos debates acerca do projeto. Com efeito, nota-se que alguns de seus pontos realmente remetem a tal teoria, principalmente no que refere às tentativas de dificultar a aquisição de terras e de estabelecer um preço justo a ser pago por elas. Entretanto, tal inspiração tornou-se inócua, totalmente comprometida com a proibição, ainda que temporária, de compra de terra pelos imigrantes e com a atribuição ao Governo, e não aos particulares interessados, de arcar com as despesas da imigração de mão-de-obra. Assim, constata-se que, no Brasil, houve uma distorção na aplicação da teoria de Wakefield.
} 
da imigração ${ }^{5}$, da regularização da propriedade territorial. Em seus principais pontos, o projeto propugnava pela (i) revalidação das sesmarias caídas em comisso, isto é, aquelas que não cumpriram as condições de doação; (ii) legitimação das posses de período superior a um ano e um dia e que não ultrapassem meia légua quadrada no terreno de cultura e duas léguas nos campos de criação; (iii) registro e demarcação das posses num prazo de seis meses, após o qual seriam aplicadas multas e, passados seis anos sem demarcação ou registro, se daria a incorporação das terras ao Estado; e (iv) criação de um imposto territorial anual e de uma taxa de revalidação das sesmarias e legitimação das posses.

Por sua vez, a Lei de Terras efetivamente aprovada promoveu uma série de modificações no projeto de 1843. E foi justamente por meio de tais modificações que a Lei de Terras tornou-se uma importante engrenagem da estratégia política dos conservadores, chamada por Lígia Maria Osório da Silva de "estratégia saquarema" . Como bem nota SILVA (1990:179), tais mudanças tiveram um forte caráter conciliatório, buscando compor e ajustar os interesses das classes economicamente dominantes. Esse caráter conciliatório transparece especialmente em algumas diferenças fundamentais guardadas pela lei em relação ao projeto.

Primeiramente, a alteração dos limites das posses a serem legalizadas. O projeto de 1843 foi acusado pelos deputados de querer expropriar os possuidores de terras, por

\footnotetext{
${ }^{5}$ Considerando o problema de terras e o de colonização assuntos imbricados, o projeto de lei solicitou também propostas quanto ao processo colonizatório, processo este que, após 1830, havia sido praticamente estancado, havendo inclusive, em 1831, proibição do Governo de realizar despesas com a imigração. Aliás, o entendimento de que as questões de terras e colonização deveriam ser tratadas conjuntamente consolidaria, na opinião de Lígia Maria Osório Silva, a tendência a privilegiar como "motivação principal da intervenção do Estado a preocupação com a mão-de-obra e a relegar a segundo plano a questão do ordenamento territorial" (SILVA, 1990: 115).

${ }^{6}$ A "estratégia saquarema" deve ser entendida no contexto histórico em que foi implementada. Desde seu projeto inicial, de 1843, a Lei de Terras pretendeu tratar como assuntos imbricados a questão da regularização da propriedade de terras e da colonização. Tendo a Lei Eusébio de Queiroz, em 1850, posto no horizonte a abolição da escravidão, a preocupação mais presente nas discussões políticas era a forma de substituição do trabalho escravo. Com isso, a Lei de Terras passou a ter a colonização como problema principal a responder, relegando a um segundo plano a regularização das terras, a ser desenvolvido apenas na medida em que facilitasse e, principalmente, até onde não atrapalhasse a colonização.

A visão política de vinculação estreita entre esses dois problemas, a colonização e a regularização imobiliária, deve-se ao que Lígia Maria Osório da Silva chamou de "estratégia saquarema". Tal estratégia consistiria, resumidamente, nas seguintes posturas: (i) defesa do gradualismo da substituição do trabalho escravo pela mão-de-obra livre, mantendo-se a escravidão paralelamente ao programa de introdução de imigrantes pelo governo; (ii) incentivo da imigração européia, não só para substituição do trabalho escravo, mas também com a finalidade de povoamento do extenso território nacional e branqueamento da população; (iii) empenho em regularizar a demarcação das terras devolutas, para que as terras demarcadas pudessem ser vendidas e financiassem a imigração regular, isto é, subsidiada pelo governo (SILVA, 1990:157-174).
} 
fixar limites máximos para os tamanhos das posses. Na época da discussão do projeto, as críticas a esses limites conseguiram apenas flexibilizar a norma, no sentido de que as posses efetivadas até 1822 seriam completamente legitimadas, não estando sujeitas a limites de tamanho. A Lei de Terras, por sua vez, não fixou limite algum para a legitimação das posses. Além disso, a lei ainda mantinha na posse da terra o posseiro caído em comisso. Isso tranqüilizou inúmeros grandes possuidores que se sentiriam prejudicados por uma norma mais rígida.

Em segundo lugar, a Lei de Terras se adaptou aos interesses econômicos dominantes ao abandonar a idéia de instituição do imposto territorial, prevista no projeto de 1843. Os senadores conseguiram a retirada dos dispositivos relativos a tal idéia. Nesse sentido, a lei mereceu diversas críticas de seus contemporâneos, críticas estas importantes por já demonstrarem a clara preocupação em restringir, de alguma forma, a indiscriminada apropriação territorial.

Por fim, há de se fazer uma ressalva. Nem todas as modificações operadas no projeto de lei de 1843 durante sua discussão parlamentar atendiam aos interesses conservadores $^{7}$. Talvez a principal exceção seja a descentralização operada pela Lei de 1850. Inicialmente, o projeto de lei tinha uma acentuada tendência centralizadora, concentrando nas mãos da burocracia imperial tanto o processo de imigração como o de demarcação das terras. Embora longe de abandonar essa tendência, o processo de flexibilização pelo qual o projeto passou fez com que, buscando um caráter conciliatório, a lei concedesse aos Presidentes da Província a prerrogativa de comandar a demarcação de terras particulares. Tal mudança teve como efeito sujeitar, na demarcação de terras, a atuação do governo imperial à dos governos provinciais.

\subsection{Da (in)aplicação da Lei de Terras de 1850.}

\footnotetext{
${ }^{7}$ Possivelmente se possa atribuir estas concessões feita pelos conservadores a um importante aspecto destacado por José Murilo de Carvalho: havia, na época, uma forte tendência a entender impraticável a implementação da lei. Neste sentido:

“O radicalismo do projeto - para as circunstâncias da época - talvez tenha contribuído para sua aprovação: muitos não acreditavam na possibilidade de implementação, caso passasse pelo Senado. Daí, talvez, também, a pouca cobertura dada pela imprensa aos debates. O jornal $O$ Brasil, de Justiniano José da Rocha, que apoiava o gabinete de 1843, deu apenas duas notícias. Achava o projeto muito importante, mas irrealista, parecendo-lhe mais um meio de distrair a atenção pública das questões políticas. Não acreditava poder existir 'governo tão temerário que quisesse executar essa lei de pronto, em poucos meses, em todo o Império'. A execução, achava, 'levaria anos, dezenas de anos"” (CARVALHO, 1988:91).
} 
Se o comentado caráter conciliador da Lei de Terras, por um lado, possibilitou sua aprovação, por outro, impossibilitou, em certa medida, sua aplicação. Isso porque, como insinua SILVA (1990:183), os problemas que a lei pretendia conciliar eram, em boa parte, inconciliáveis. Por um lado, para atender ao interesse dos grandes proprietários de terras, a lei precisava vedar o acesso à propriedade de terras para os imigrantes, garantindo que suas mãos estivessem disponíveis para o trabalho na grande lavoura. Por outro, a mesma lei pretendia incentivar a imigração espontânea, atraindo imigrantes estrangeiros, com a finalidade de deixar de comprometer com a imigração regular o minguado orçamento imperial, e, para tanto, acenava aos estrangeiros com a promessa de compra de certa porção de terra.

Além disso, outro fator que dificultou a efetivação da regulamentação de terras pretendida pela Lei de 1850 foi a sujeição da atuação do governo imperial à dos governos provinciais na demarcação de terras, uma vez que a demarcação das terras particulares deveria ser comandada por estes últimos, e a demarcação das terras devolutas dependia da das terras particulares. Assim, submetida à atuação dos governos provinciais, toda centralização promovida pela Lei de Terras restou comprometida ${ }^{8}$.

Com isso, durante a segunda metade do séc. XIX, assiste-se a uma seqüência de criações e extinções de órgãos da Administração Pública encarregados da demarcação de terras, sem que essas diversas substituições tenham surtido efeitos relevantes, por não atingirem o cerne do problema.

\footnotetext{
8 "O ponto fraco de todo sistema era o fato de que a iniciativa primeira, que desencadearia todo o processo, de demarcação de terras, estava nas mãos dos particulares. Tudo dependia da informação pretendida pelo governo sobre a existência ou não de terras devolutas em tal ou qual termo, comarca ou município. Então os organismos competentes iniciariam a devida medição e demarcação e isto tornaria possível a destinação destas terras para a venda e a colonização. Entretanto, esta informação ficava na dependência da demarcação das terras sob o domínio dos particulares que, por efeito da lei, seriam legitimadas ou revalidadas. $\mathrm{O}$ juiz comissário encarregado da medição e demarcação destas terras, por sua vez, tinha que esperar o requerimento dos particulares para dar início ao processo. Estas informações, só então, chegariam ao Presidente da Província que informaria os órgãos competentes. Finalmente, estes órgãos saberiam quais as terras que naquele termo, comarca ou município estavam apropriadas e em processo de legalização. O que sobrasse eram terras devolutas. No centro, portanto, de todo o processo, estava o fator que acionaria todo o mecanismo: o requerimento do posseiro ou sesmeiro para medir e demarcar suas terras" (SILVA, 1990:226-227).
} 
Exemplos das criações e extinções de órgãos são a Repartição Geral de Terras Públicas $^{9}$, as Repartições Especiais das Terras Públicas ${ }^{10}$ e o Registro Geral e Estatística das Terras Públicas e Possuídas ${ }^{11}$.

\subsection{A situação da demarcação de terras no final do Império.}

Impulsionado pela discussão gerada com a Lei do Ventre Livre, o decreto $\mathrm{n}^{\mathrm{o}}$ 6.129, de 23 de fevereiro de 1876, viria a criar a Inspetoria de Terras e Colonização. O mesmo ato que criou nas províncias as Inspetorias Especiais extinguiu as Repartições Especiais, entregando àquelas a fiscalização das colônias e das comissões de medição. Com a criação da Inspetoria, o governo imperial eliminou a intermediação dos Presidentes das Províncias no processo de demarcação, passando o Ministério da Agricultura a se comunicar diretamente com a Inspetoria, que, por sua vez, recebia as informações diretamente dos delegados das Inspetorias Especiais de cada Província.

A Inspetoria de Terras buscou concentrar seus esforços na demarcação das áreas onde se suspeitava houvesse maior quantidade de terras devolutas próprias para colonização. Apesar da estratégia interessante, os resultados alcançados pouco se diferenciaram daqueles atingidos pelos órgãos anteriores.

A adversa situação do serviço de terras do fim do período imperial é bem descrita pelo último relatório da Inspetoria Geral de Terras e Colonização, datado de 1888 e assinado pelo então Inspetor Geral, tenente-coronel Francisco de Barros Accioli e Vasconcellos, que viria a ser deposto com a Proclamação da República:

\footnotetext{
${ }^{9}$ Foi o que aconteceu com a Repartição Geral de Terras Públicas, criada pelo art. 21 da lei de 1850. Tratavase de uma repartição especial dirigida à medição, divisão e descrição das terras devolutas, além de sua conservação, fiscalização, venda e distribuição. Ademais, a Repartição Geral ainda se responsabilizava pela promoção da colonização. Sem quase nada ter feito pela demarcação de terras, tal repartição foi extinta em 1861, com a criação do Ministério da Agricultura, Comércio e Obras Públicas.

${ }^{10}$ Com a criação do Ministério da Agricultura, Comércio e Obras Públicas, passou-se aos governos provinciais, por meio das Repartições Especiais das Terras Públicas, a responsabilidade pela manutenção de um Registro de Terras, o que praticamente estancou os trabalhos de demarcação.

${ }^{11}$ A percepção do agravemento do problema da demarcação de terras e a esperança de conhecer as terras devolutas que lhe haviam sobrado levou o governo imperial a expedir, em 4 de outubro de 1873, um aviso pelo qual os posseiros que ocupassem terras antes de 1854 ficavam autorizados a comprá-las. No ano seguinte, seria ainda criado o Registro Geral e Estatística das Terras Públicas e Possuídas, extinto sem alcançar sucesso.
} 
"[O serviço de medição e discriminação das terras devolutas] durante o ano findo teve limitado desenvolvimento, restringindose, com poucas exceções, os trabalhos das comissões à discriminação das zonas necessárias para o estabelecimento de núcleos coloniais. Continua esta Inspetoria sem elementos para organizar convenientemente o movimento relativo às legitimações e revalidações de posses, assim como à venda das terras devolutas feitas nas Províncias, por não receber as devidas informações, o que, aliás, não parece difícil ministrar, visto que todos esses trabalhos dependem de uma só repartição" (apud SILVA, 1990:292).

Em seu clássico livro intitulado Teatro de sombras: a política imperial (1988), José Murilo de Carvalho dedica um capítulo especialmente à política de terras imperial, artigo este que, inclusive, seria publicado com algumas alterações na Revista Brasileira de História como artigo autônomo, intitulado Modernização Frustrada: a Política de Terras no Império. Ao comparar a política de terras à política abolicionista o autor entende que, embora ambas atingissem de maneira profunda os interesses de boa parcela dos proprietários de terras, há diferenças marcantes elas. Ao contrário da política abolicionista, a política de terras teria provocado o alinhamento de proprietários de diferentes setores agrários. Com isso, alcançou força política tal que permitiu que a política de terras quase não saísse do debate legislativo e dos relatórios dos burocratas dos ministérios do Império e da Agricultura, Comércio e Obras Públicas (CARVALHO, 1988:84). Desta forma, a política de terras teria sido vetada pelos barões, daí o título do capítulo: A política de terras: o veto dos barões.

Com efeito, vê-se que durante todo o Império permaneceram sem mapeamento as terras devolutas e, conseqüentemente, continuavam as invasões e apropriações sobre elas, chegando nessa situação o problema quando da Proclamação da República. 


\section{Cap. 2 - O problema do crédito agrícola na segunda metade do Império.}

\subsection{Introdução.}

Neste capítulo pretende-se analisar o problema do crédito agrícola durante o regime imperial. Entretanto, a fim de que não se desvirtue a finalidade da presente pesquisa, faz-se necessária a realização de um corte histórico. Para tanto, parece interessante principiar esta análise pelo ano de 1864. A escolha desse ano deve-se, fundamentalmente, à aprovação da Lei Hipotecária, ocorrida nele, em 24 de setembro. Foi também nesse ano que se deu a Crise Financeira, cujos efeitos em grande parte se prolongariam durante todo o fim do Império, chegando a atingir a República nascente. Outro fator importante que pesa na escolha desse marco inicial é a proximidade com que esse ano precede o de 1866, em que se deu a reforma do Banco do Brasil.

\subsection{A crise comercial de 1857 .}

Antes, no entanto, é preciso uma rápida remissão à crise comercial de 1857. Considerada a primeira crise comercial de relevância do Império, tal crise foi encarada por muitos como de origem monetária ${ }^{12-13}$, ligando-se sua causa diretamente às excessivas emissões realizadas pelo Banco do Brasil ${ }^{14}$. A reação imediata do governo distanciou-se do

\footnotetext{
${ }^{12}$ A tese monetarista de explicação da crise consistia, basicamente, em atribuí-la ao excesso de moeda, pois, com a retomada do monopólio da emissão pelo Banco do Brasil, este passara a emitir moedas numa quantidade maior que a de seus fundos, trabalhando com uma proporção multiplicadora, o que fazia com que, no eventual caso de uma repentina procura por troco, ele não pudesse honrar suas notas de forma imediata.

Para um dos defensores dessa tese, CALÓGERAS, a crise comercial internacional funcionaria, assim, apenas como estopim de uma crise já anunciada (1960:104).

${ }^{13}$ Outros fatores apontados como causa da crise de 1857 seriam (i) a intensificação das relações comerciais e financeiras, na segunda metade do século XIX, a qual trouxe como conseqüência a intensificação das especulações - além disso, o arrojamento do comportamento dos comerciantes, estimulado, segundo alguns, pela facilidade creditícia propiciada pelo então novo Código Comercial (promulgado em 1850), o qual teria aumentado as quebras de contrato (SOARES, 1865); (ii) o fim do tráfico negreiro em 1850, que liberou para novos investimentos o capital antes empregado nessa atividade, embora seja certo que parte desse capital se direcionou ao tráfico interprovincial e outra parte emigrou com a deportação dos traficantes portugueses (LUZ, 1960:77); (iii) um repentino e volumoso aumento das transações na Bolsa de Valores do Rio de Janeiro, provavelmente influenciado pelas causas anteriormente apontadas (LEVY, 1977); e, por fim, (iv) uma crise comercial internacional, que atingiu o mercado norte-americano e europeu e, reflexamente, o brasileiro, com a não-renovação dos créditos de curto prazo que financiavam o comércio de importação (BOTELHO JR., 2002:7).

${ }^{14}$ Segundo BOTELHO JR. (2002:8), as emissões totais aumentaram $83 \%$ entre o segundo semestre de 1853 e o primeiro semestre de 1858 .
} 
esperado pela ortodoxia da época ${ }^{15-16}$, mas, passada a crise, não tardou para que essa tese monetarista implicasse uma espécie de contra-reforma econômica, especialmente por seus defensores assumirem cargos diretivos do governo ${ }^{17}$. Tal contra-reforma consistiu basicamente na adoção de medidas que visaram à redução das emissões realizadas pelo Banco do Brasil $^{18}$, adoção da conversibilidade-ouro ${ }^{19}$, restrição à criação de novas companhias e política de alta taxa de câmbio. Essas medidas tiveram como seu mais representativo veículo jurídico a Lei de 22 de Agosto de 1860, cujo projeto fora apresentado pelo ministro da Fazenda Silva Ferraz ${ }^{20}$.

A lei de 1860 teve um forte efeito recessivo, diminuindo sensivelmente as iniciativas de novos empreendimentos e aumentando o número de falências ${ }^{21}$. $\mathrm{O}$ governo defendeu-se alegando que apenas os empreendimentos de caráter especulativo não teriam resistido à lei de 1860 .

\subsection{A crise financeira de 1864 .}

E foi basicamente essa política econômica restritiva que se manteve até o país ser atingido pela crise financeira de 1864. Tal crise é marcada, sobretudo, pela falência de uma das mais importantes casas bancárias brasileiras do Império: a Casa Souto. Ainda que freqüente e intensamente socorrida pelo Banco do Brasil ${ }^{22}$, a Casa Souto não conseguiu arcar com o pagamento de seus bilhetes, suspendendo-o em 09 de setembro de 1864. A essa

\footnotetext{
${ }^{15}$ Ao invés da postura econômica restritiva, esperada pela ortodoxia econômica da época, a presença de Sousa Franco no Ministério da Fazenda a partir de 1857, reconhecidamente adepto da liberdade bancária, fez com que se criassem cinco bancos com direito de emissão e um outro já existente fosse autorizado a emitir.

16. "A ação do Governo na crise distanciou-se da ortodoxia comum ao período. Diminuiu as taxas de juros, socorreu casas bancárias e sustentou o câmbio por meio de operações financeiras em Londres intermediadas pelo Banco de Mauá - diante da recusa do Banco do Brasil que insistia numa política restritiva" (BOTELHO JR., 2002:10).

${ }^{17}$ Em 1859, o Ministério da Fazenda fora assumido por Torres Homem, um dos principais opositores do exministro da Fazenda Sousa Franco, um dos principais responsáveis pela política econômica heterodoxa do Governo.

${ }^{18}$ Em abril de 1859, as emissões do Banco do Brasil foram reduzidas ao dobro de seus fundos, estando a instituição a emitir pelo triplo até então.

${ }^{19}$ Os defensores da tese monetarista da crise de 1857 confundem-se, de uma forma geral, com os metalistas, isto é, com aqueles que entediam que a moeda deveria ser conversível, lastreada em ouro ou em uma divisa forte, como a libra. Além disso, os metalistas eram favoráveis à instituição do monopólio de emissão (BOTELHO JR., 2002:73).

${ }^{20}$ Em junho de 1860, Torres Homem havia proposto um projeto de lei com medidas restritivas, o qual sofreu forte oposição, a qual, inclusive, culminou na renúncia do ministro. Silva Ferraz o sucedeu na pasta, atuando sob pressupostos econômicos muito semelhantes aos de seu antecessor, mas com maior habilidade política, a qual the permitiu aprovar projeto bastante próximo ao de Torres Homem, com apenas algumas pequenas mudanças (GRANZIERA, 1979, p. 85).

${ }^{21} \mathrm{O}$ economista francês J. Granier, contemporâneo da lei de 1860, a apelidou em 1862 de Lei dos Entraves, apelido pelo qual ela ficaria conhecida em boa parte do meio acadêmico que a estudou. Cf. CALÓGERAS (1960, p. 129).
} 
suspensão sucedeu-se uma corrida a outras casas bancárias, buscando reembolso de seus bilhetes. Dada a impossibilidade de os fundos das casas bancárias arcarem com a repentina demanda, em 13 de setembro de 1864 também houve a suspensão dos pagamentos de seus bilhetes. Nesse momento, quando a corrida principiara a direcionar-se ao Banco do Brasil, o governo interveio e decretou o curso forçado dos bilhetes do banco, em 14 de setembro de 1864.

No entanto, pode-se dizer que a quebra da Casa Souto foi apenas o estopim de uma crise que se deveu, dentre outras causas ${ }^{23}$, às políticas econômicas aplicadas pelo governo imperial desde a crise de 1857. Com efeito, aponta-se como uma das principais causas da Crise de 1864 a política monetária, com a excessiva valorização da moeda nacional frente à libra esterlina, conseqüência da restritiva política de emissão de moeda. Vale lembrar que, desde 1860, o governo havia adotado a conversibilidade da moeda, o que teria influenciado na acentuada escassez de que padecia o meio circulante em 1864.

Além disso, uma outra causa para a crise é apontada. E essa tem uma importância especial para a presente pesquisa. Trata-se dos problemas enfrentados pelos financiadores na concessão de empréstimos sem que houvesse garantias adequadas do pagamento. Tratando da relação desses problemas com a Crise de 1864, BOTELHO JR. diz:

\begin{abstract}
"Por fim, não se pode desprezar o fato de que a concessão de empréstimos com garantias duvidosas e existência de fraudes diversas também contribuíram para abalar a saúde financeira das casas bancárias, desde o curto pânico de 1862 em situação de perigo" (2002:16).
\end{abstract}

\footnotetext{
${ }^{22}$ SOARES, um autor contemporâneo da quebra da casa, estima que quando esta ocorreu, aproximadamente $66 \%$ do capital do Banco do Brasil estava a ela emprestado (1865, p. 50-1).

${ }^{23}$ Ao lado das causas de política econômica, a crise de 1867 deveu-se também a uma causa natural. Trata-se de uma praga que atingiu os canaviais fluminenses. BOTELHO JR. explica da seguinte maneira a relação entre a praga e a crise:

"A praga que atingiu os cafezais fluminenses - reduzindo assim sua produtividade já comprometida pela fertilidade decrescente do solo - provocou uma quebra de safra e, por conseguinte, da renda dos cafeicultores. Como estes eram clientes dos comissários, suas dificuldades rapidamente os alcançaram. Por sua vez, os comissários eram clientes das casas bancárias, sendo estas então também atingidas pelos problemas nos cafezais" (2002:14).
} 
Com efeito, o financiamento agrícola era ao mesmo tempo uma das necessidades mais prementes e um dos problemas mais urgentes a ser enfrentado pelo governo.

Pela ótica dos financiadores, os empréstimos tinham garantias bastante deficientes, tendo em vista que até então as dívidas eram normalmente garantidas pela propriedade de $\operatorname{escravos}^{24}$, a qual se encontrava em franca decadência pelo paulatino processo de ilegitimação a que se submetia, devido em grande parte à pressão internacional para a abolição. A propriedade que naturalmente poderia substituir a de escravos enquanto garantia de empréstimos seria a propriedade de terra. No entanto, certas dificuldades obstaram a imediatidade dessa substituição ${ }^{25}$. A inexistência de um sistema minimamente adequado de registro de propriedade imobiliária tornava altamente arriscado o empréstimo por ela garantido. Além disso, a facilidade na apropriação de terras às margens da lei, por meio de violência e fraude, diminuía sensivelmente o valor da terra, tornando-o muito inferior à propriedade servil.

Por outro lado, pela ótica dos tomadores de empréstimo, a deficiência do sistema bancário da época tornava os empréstimos agrícolas altamente dispendiosos para os devedores $^{26}$.O insatisfatório desenvolvimento do sistema bancário abria espaço para a

\footnotetext{
${ }^{24}$ De acordo com a lei da escravatura, o escravo era um semovente. Como tal, o seu proprietário ou possuidor, além de poder vendê-lo, poderia alugá-lo, emprestá-lo, gravá-lo em garantia de uma dívida. Note-se, entretanto, que, pela lei, somente estavam sujeitos à hipoteca os escravos pertencentes a estabelecimentos agrícolas.

${ }^{25}$ Ao comentar a dependência do sistema escravista a que se submetiam os cafeicultores, entendendo estarem estes inclusos em um círculo vicioso de todo um modo de produção (e reprodução) escravista, SAES escreve sobre a importância da propriedade escravagista no financiamento da produção e a correlata incapacidade da propriedade imobiliária em substituí-la (note-se que os grifos do trecho são de autoria do próprio SAES):

“(...) para que se possa entender em toda as suas dimensões o interesse dos cafeicultores em conservar a existência do trabalho escravo, é preciso ir além da esfera de produção escravista (avaliação da rentabilidade do trabalho escravo) e observar, igualmente, a esfera de circulação. Esta possui, no modo de produção escravista moderno, uma particularidade: a propriedade escrava é a base de todo o crédito. Para que possam obter dinheiro de banqueiros, usuários ou exportadores, os plantadores devem fundamentalmente apresentar enquanto o produtor direto se constituir legalmente em propriedade do proprietário dos meios de produção o escravo, e não a terra, como garantia hipotecária. Um indício expressivo dessa peculiaridade nos é apresentado por Robert Conrad: até mesmo em 1887 (auge da luta escrava, do movimento de fugas), quando

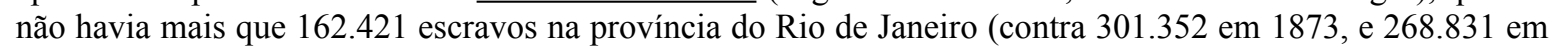
1882), o "valor contábil" do total de escravos praticamente equivalia ao valor total das dívidas (120 mil contos de réis) contraídas pelos plantadores junto a banqueiros e usuários; e era superior ao preço total das terras provinciais. Como se pode depreender, a terra estava longe de poder substituir, nessa região fluminense, o escravo como garantia hipotecária; por isso, os plantadores da região consideravam que a extinção legal da escravidão provocaria a sua ruína financeira" (SAES,1985:201-202).

${ }^{26}$ Descrevendo o baixo nível de desenvolvimento do sistema bancário brasileiro no período e relacionando-o à escassa e dispendiosa disponibilidade de crédito agrícola, MARCONDES escreve:

"A ausência de um sistema bancário desenvolvido no período propiciava uma remuneração expressiva aos fornecedores do crédito para a economia cafeeira. Os poucos bancos existentes atuavam essencialmente por meio de sua carteira comercial de curto prazo e, dependendo da política econômica do momento, da
} 
atuação de comissários $^{27}$, cujas intermediações também contribuíam para a elevação das taxas de juros para os tomadores finais. Havia forte pressão dos fazendeiros, em especial dos cafeicultores, por formas de financiamento menos onerosas ${ }^{28}$ e a maiores prazos.

\subsection{A tentativa de instituição do crédito hipotecário.}

Notando a influência dos problemas da garantia do financiamento agrícola na crise financeira, o governo procurou reduzir o custo dos empréstimos ${ }^{29}$ e alongar o prazo de vencimento da dívida para os agricultores, e tal tentativa se deu por meio do aprimoramento

capacidade de emissão. Na província de São Paulo, a situação do crédito mostrava-se ainda mais crítica, pois até 1870 havia apenas a Caixa Filial do Banco do Brasil e em 1880 existiam três bancos. Em 1889, encontravam-se em funcionamento no território paulista 10 bancos. As elevadas taxas de juros implicaram constantes reclamações dos agricultores e habitantes de diversas localidades. Os cafeicultores pressionavam por formas de financiamento menos onerosas e a mais longo prazo" (2002:149).

${ }^{27}$ A respeito da intermediação realizada pelos comissários entre os tomadores de empréstimo e os bancos, enfatizando a função destes enquanto prestamistas daqueles, STEIN disse:

"Constituindo de longe, o mais ativo e poderoso setor do comércio do Rio de Janeiro, os comissários sacavam abundantemente sôbre as vinte e uma casas bancárias fundadas na década de 50 e 60 . A despeito dos serviços prestados pelos estabelecimentos bancários aos comissários, os capitais de que dispunham eram relativamente restritos; individualmente, nenhum dêles possuía o capital do Banco do Brasil, instituição oficial, com seus 30.000 contos. Redescontavam no Banco do Brasil títulos de crédito assinados pelos comissários. O Banco do Brasil se transformou, assim, de fato, em 'banqueiro dos bancos"” (STEIN, 1961: 255-256).

${ }^{28}$ Alguns pesquisadores buscaram levantar as taxas regionais de juros da época. Estudando São Paulo de meados do século XIX, SAES encontra "o nível vigente da taxa de juros no intervalo de 12 a $18 \%$ ao ano" (SAES 1986:68). Em Lorena, MARCONDES verificou taxas ao redor de 20\% para o período de 1830 a 1849 e de $16 \%$ para o momento de 1850 a 1872 nos créditos registrados nos inventários compulsados (MARCONDES, 1998:230).

${ }^{29}$ No Relatório da Comissão de Inquérito sobre a crise financeira de 1864, Sebastião Ferreira Soares procurou explicar os motivos das elevadas taxas de juros para os agricultores nos anos anteriores à lei hipotecária em função da presença de intermediários:

"Em sua maior parte os dinheiros para suprimento dos fazendeiros são tomados pelos comissários aos seus banqueiros aos juros correntes, e sobre eles carregam mais $2 \%$ de garantia aos fazendeiros, de sorte que estes sempre pagam pelo menos mais $4 \%$ que o desconto estipulado pelo Banco do Brasil, porquanto não tendo, no cadastro do Banco do Brasil crédito aberto ao fazendeiros, as firmas destes não são aceitas naquele estabelecimento, pelo que só com as firmas dos comissários são descontados os seus títulos nos banqueiros, que assim se constituíram intermediários dos fazendeiros e do Banco regulador de crédito, e por isso mais $2 \%$ carregam que o Banco pela sua garantia. Ora, sendo o desconto mais geral do Banco do Brasil na razão de 9 a $10 \%$ ao ano, segue-se que os fazendeiros mais favorecidos não obtêm dinheiro na praça com menores juros de 13 e $14 \%$ ao ano, o que lhes é extremamente gravoso". 
e da ampliação do instituto da hipoteca ${ }^{30}$ como garantia dos empréstimos, promulgando, em

24 de setembro de 1864, uma lei que estabelecia as normas que a regulariam.

Segundo SCHULZ (1996:50), até 1864 várias razões praticamente inviabilizavam

as hipotecas sobre a terra, dentre as quais se destacam a falta de mercado para as terras e a insegurança que as deficiências do sistema registral geravam sobre os títulos de propriedade de terra. Além disso, havia uma lei que exigia que as hipotecas não ultrapassassem metade do valor da terra. Lei esta que, visando à proteção dos agricultores, acabou por inibir ainda mais as hipotecas sobre imóveis.

A respeito da importância dessa lei, CALÓGERAS diria que:

"A lei de 24 de setembro de 1864 estabelecera as normas para os empréstimos sobre hipotecas; era possível, portanto, levar à carteira de emissões hipotecárias, inteiramente distinta da carteira comercial, esses títulos de liquidação remota, provindo, na realidade, e em sua grande maioria, de empréstimos concedidos aos agricultores, os quais, desse modo, entender-se-iam diretamente com o banqueiro sem o intermédio de terceiros nem o desembolso de corretagens especiais" (1960:154).

\footnotetext{
${ }^{30}$ A crise apenas agravou uma situação preexistente, pois, já na primeira metade do século XIX, se agitavam os debates parlamentares em torno da necessidade de dotar o mercado de uma ferramenta eficaz para garantia dos empréstimos. Em 1838, foi apresentado, por proposta do deputado Aureliano de Souza e Oliveira Coutinho, um projeto de criação de ofício privativo de hipotecas, apontamentos e protesto de letras. Após longo debate parlamentar, tal projeto foi transformado em lei de 14 de novembro de 1846. Seu autor assim justificava o projeto:

“(...) parece da necessidade uma lei, que criando em cada município um ofício, e registro especial de hipotecas, e de protesto de letras, ponha os cidadãos, e particularmente o comércio, a abrigo das contínuas fraudes, que diariamente se praticam, hipotecando-se a indivíduos por um cartório prédios já hipotecados a outros por cartórios diferentes; e bem assim o habilite a conhecer prontamente aqueles, que pouco pontuais em seus pagamentos, deixam apontar, e protestar suas letras, a fim de que estabelecida a confiança, mãe do comércio, possa esse prosperar, como muito convém aos interesses do país". Muito antes disso, "parece da necessidade uma lei, que criando em cada município um ofício, e registro especial de hipotecas, e de protesto de letras, ponha os cidadãos, e particularmente o comércio, a abrigo das contínuas fraudes, que diariamente se praticam, hipotecando-se a indivíduos por um cartório prédios já hipotecados a outros por cartórios diferentes; e bem assim o habilite a conhecer prontamente aqueles, que pouco pontuais em seus pagamentos, deixam apontar, e protestar suas letras, a fim de que estabelecida a confiança, mãe do comércio, possa esse prosperar, como muito convém aos interesses do país. (...) é sabido que muitos sujeitos, que aliás desejariam fazer girar, e reproduzir seus fundos, recusam dá-los sobre hipotecas de bens de raiz por ignorarem se tais bens estão sujeitos, em todo ou em parte, a outros contratos e por temerem os prejuízos que de tais fraudes se têm seguido; donde também resulta que muitos proprietários são privados de fazer duplicadamente produtivas suas propriedades, obtendo sobre elas fundos, com que as possam melhorar, aumentar, ou entrar em outras especulações".
} 
Em algumas regiões, a introdução da hipoteca como garantia de empréstimo teve efeitos benéficos imediatos no sistema de crédito da economia cafeeira. Em estudo sobre o financiamento da cafeicultura no Vale do Paraíba Fluminense, mais especificamente em Vassouras, SWEIGART nos dá certa dimensão dessa alteração:

\begin{abstract}
"Uma nova era em financiamento agrícola chegou ao Brasil com a conversão do Banco do Brasil e do Banco Predial em instituições hipotecárias. A guerra com o Paraguai havia sido ganha, e os altos preços do café eram propícios para os bancos hipotecários envisionados na legislação de 1864 e 1865. (...) Companhias angariariam grandes quantidades de capital para investir em plantações a longo prazo, sob condições de crédito melhores criadas pelo claro registro de garantias: terra e escravos. Com o risco diminuído, os plantadores pagariam taxa de juros menor ou igual à taxa de desconto, eliminando assim o lucro do mediador”’31.
\end{abstract}

Como observa MELLO, também ele se referindo à região de Vassouras, a hipoteca era uma das principais fontes de capital, advindo grande parte desses empréstimos de fontes locais:

“(...) os fazendeiros de café obtinham cerca de $40 \%$ de suas necessidades de capital das fontes locais. A maior parte desses emprestadores eram outros fazendeiros ou então comerciantes da cidade. Os empréstimos tinham por garantia hipotecas das propriedades rurais, o prazo era em geral de 2 a 4 anos e a taxa de juros oscilava entre 10\% e 12\%" (MELLO, 1984:244).

\footnotetext{
31 "A new era in agricultural finance in Brazil arrived with the conversion of the Banco do Brasil and the Banco Predial into mortgage institutions. The war with Paraguay had been won, and high coffee prices were propitius for the mortgate banks envisioned in the legislation of 1864 and 1865. (...) Companies would amass large amounts of capital to invest in plantations for long terms, under the improved credit conditions created by the clear registration of collateral: land and slaves. With risk diminished, planters would pay interest rates at or below the discount rate, thus eliminating the profit of the middleman" (SWEIGART apud MARCONDES, 2005:03, tradução livre).
} 
Em reforço às normas estabelecidas por essa lei, a instituição da hipoteca também seria incentivada por uma reforma sofrida pelo Banco do Brasil, implementada em 1866. Tal reforma, instituída pela lei $\mathrm{n}^{\mathrm{o}} 1.349$, de 12 de setembro de 1866, após intenso debate político $^{32}$, buscou transformar parte da carteira comercial do banco em carteira hipotecária e de penhor agrícola (PELÁEZ e SUZIGAN, 1981:115-116).

Basicamente, a lei $\mathrm{n}^{\mathrm{o}} 1.349$ tinha como principais pontos: (i) o fim da capacidade emissora do Banco do Brasil, que apenas continuaria com as operações autorizadas e os empréstimos hipotecários; (ii) a divisão do banco em duas repartições, a Carteira Comercial e a Carteira Hipotecária ${ }^{33}$, as quais responderiam a uma mesma administração, porém teriam fundos separados.

Após certo adiamento na criação da Carteira Hipotecária ${ }^{34}$, somente em 1867 seria regulamentada pela direção do Banco do Brasil a repartição das hipotecas, fixando regras que na prática viriam a limitá-las sobremodo. Por exemplo, como regra, somente seriam aceitas hipotecas de imóveis localizados no "município neutro da corte, na Província do Rio de Janeiro e nos municípios que com ela fossem limítrofes em São Paulo, Minas Gerais e Espírito Santo", e hipotecas sobre imóveis de outras localidades somente seriam aceitas excepcionalmente, e mesmo assim para garantir os títulos já existentes na Carteira (PIÑEIRO, 1996:47). Tal regulamentação limitadora da utilização da hipoteca, somada à

\footnotetext{
${ }^{32}$ Ao comentar o debate em torno do projeto de lei, PIÑEIRO descreve o forte impasse entre o então ministro da Fazenda, Carrão, contrário à reforma, e o ministro da Agricultura, Paula e Souza, favorável ao projeto. Tal impasse terminou com a renúncia daquele, que teve como conseqüência a saída de outros ministros do Governo.

A respeito do debate político, PIÑEIRO ainda acrescenta:

“As questões que faziam oporem-se as frações que compunham o 'bloco no poder' relacionavam-se, por um lado, à defesa da capacidade emissora pelo Banco do Brasil, pois esta atividade era altamente lucrativa, e, por outro, às necessidades de financiamento das atividades urbanas, até então bastante protegidas por aquele estabelecimento, como nas crises de 1857 e 1864. Após inúmeros debates no Senado e na Câmara, tratados com grande rapidez, pela pressão dos interessados, e incorporando sugestões da Comissão do Senado, o projeto foi aprovado" (1996:46).

${ }^{33}$ A fim de atender à demanda do setor agrícola, a Carteira Hipotecária do Banco do Brasil recebeu, quando da sua criação, a importância de 35.000 contos, os quais deveriam ser convertidos em títulos hipotecários.

${ }^{34}$ PIÑEIRO aponta quais as causas do referido adiamento na implantação da Carteira Hipotecária:

"Entretanto a empresa [Banco do Brasil] não demonstrava grande interesse na Carteira Hipotecária e, apesar da pressão dos proprietários de terra, o Banco buscou adiar ao máximo a implantação da mesma. Também por parte das forças políticas, a implementação não pôde ser apressada, uma vez aprovada a Lei de Reforma de 1866, pois o controle das emissões passava de fato para o governo do império e a manutenção da unicidade das emissões dividia os grupos que haviam apoiado a nova legislação. Esta divisão no grupo que havia propiciado a aprovação das novas regras que iriam reger o funcionamento do Banco do Brasil, do tesouro e das emissões, permitiu a atuação dos adversários da criação da Carteira Hipotecária" (1996:47).
} 
relativamente pequena concessão de empréstimos hipotecários quando comparados à dotação do Banco e, ainda, ao uso dos recursos que deveriam ser destinados à agricultura para realização de empréstimos ao governo, fez com que a Carteira Hipotecária fosse relegada a segundo plano, ainda que sob fortes críticas do setor agrícola.

Apenas em 1871 se acenaria uma mudança quanto a essa postura. Nesse ano, a diretoria do Banco propôs ao governo que fosse ampliado e aprimorado o crédito agrícola, através da Carteira Hipotecária, com a concessão de empréstimos de longo prazo e a baixos juros. Em contrapartida, o Banco pleiteava a prorrogação de autorização para seu funcionamento por mais quatorze anos e a diminuição do resgate de suas notas que ainda se encontravam em circulação. Ou seja, o banco pretendia compensar os créditos concedidos à lavoura com a redução do resgate dos bilhetes.

Apesar de sofrer intensas críticas, foi aprovado o projeto de lei de autoria do ministro da Fazenda que contemplava as mudanças legislativas pretendidas pelo Banco ${ }^{35}$. Após essa nova mudança legislativa, agora, sim, o Banco do Brasil começava a promover a implementação da hipoteca, complementando a totalidade de sua dotação com as letras hipotecárias lançadas a partir de 1874.

\subsection{A crise financeira de 1875 .}

Em 1875, a economia brasileira foi assolada por uma forte crise. De uma maneira geral, duas são as principais causas apontadas pelos historiadores econômicos para a crise de 1875: (i) o cenário internacional desfavorável ${ }^{36-37}$ e (ii) a escassez interna do meio circulante. Esta última causa interessa especialmente à presente pesquisa.

\footnotetext{
35 "O resgate das notas era reduzido a $2,5 \%$ ao ano; o prazo de funcionamento do Banco do Brasil era prorrogado por quatorze anos; estipulava em 25.000.000\$ o mínimo do volume de recursos que deveriam ser emprestados à agricultura (logo uma redução de quase $30 \%$ da dotação originária) e fixava em $6 \%$ a amortização e $5 \%$ de juros ao ano, estendendo as condições aos contratos ainda em vigor" (PIÑEIRO, 1996:48).

${ }^{36}$ Apesar da relativa prosperidade experimentada no início da década de 70, a partir do ano de 1873 a economia mundial se retrai, entrando em crise. É apontado como momento decisivo da gênese dessa crise a quebra da Bolsa de Valores de Viena, à qual se seguiu uma elevação da taxa de descontos do Banco da Inglaterra.

${ }^{37}$ SCHULZ (1996) associa a crise de 1875 a este movimento da economia mundial, cujos efeitos teriam chegado de forma retardada ao Brasil, fazendo com que o preço do café caísse. Por outro lado, BOTELHO JR. (2002), embora não despreze a influência externa na crise brasileira, relativiza essa hipótese "exogenista" da causa da crise, entendendo que a queda nos preços do café a partir de 1875 teria sido em certa medida compensada pelo comportamento dos preços de outros produtos de exportação, não havendo evidências de problemas na balança comercial na intensidade necessária para que se provocasse uma crise financeira. Além disso, o mesmo autor questiona a que se deveria o retardamento do reflexo da crise internacional no Brasil, desconfiando da defasagem de dois anos entre uma e outra crise.
} 
A Guerra do Paraguai é apontada como uma das principais razões do problema da escassez do meio circulante. Mais especificamente, o problema teria sido causado pelos vultosos gastos públicos empregados no financiamento do conflito. Com efeito, o alto custo da mobilização de grande número de soldados, bem como da disponibilização de munições e víveres, aumentou de forma acentuada as despesas estatais. Embora no mesmo período tenha ocorrido um significativo aumento da arrecadação, tal não foi suficiente para fazer frente aos gastos bélicos, gerando déficit estatal.

Ao tratarmos, como fator fundamental da crise do Império, da relação entre a Guerra do Paraguai e a deterioração das finanças públicas, é obrigatória a referência ao trabalho de Wilma Peres Costa, intitulado A questão fiscal na transformação republicanacontinuidade e descontinuidade.

A autora encara a Guerra do Paraguai, ao lado da diversificação da base socioeconômica $^{38}$, como um dos fundamentos da crise política da década de 70 :

"A crise da década de 1870 tem, portanto, um de seus fundamentos na diversificação da base socioeconômica. O outro fundamento da crise, que se tornou endêmica a partir da década de 1870 do século passado, está relacionado com a Guerra do Paraguai (1865/1870) em alguns aspectos que é preciso mencionar. Foi a partir dela que se abriu o fosso, fatal para o destino do Império, entre as forças armadas e as instituições políticas da monarquia. Além disso, foi em razão da Guerra que o timing do processo de emancipação passou a ser encarado como 'questão de Estado', provocando, junto com a crise do comando, a célebre inversão partidária de 1868

\footnotetext{
${ }^{38}$ A diversificação da base socioeconômica, ocorrida especialmente a partir da década de 1870 , tem ainda grande relevância no aceleramento do anseio descentralizador, intimamente vinculado ao declínio do Império e à ascensão do regime republicano, como bem nota COSTA:

"O fulcro da questão radicava, entretanto, na crescente diversificação da base econômica a partir da década de 1870, com o florescimento da cafeicultura do Oeste paulista e a heterogeneidade que se aprofundava, a partir daí, entre o Centro-Sul e o Nordeste. O timing da emancipação, a forma e o preparo da transição para o trabalho livre, encontravam demandas regionais diferenciadas e divergentes: a imigração em São Paulo, os engenhos centrais no Nordeste, as ferrovias em toda parte. A partir do momento em que se rompia o consenso básico que sustentara o Império, o Estado como biombo externo para a manutenção da escravidão e garante interno de tráfico interprovincial, não era mais possível pensar políticas capazes de satisfazer interesses que se tornavam cada vez mais diferenciados. O federalismo, pois, ganhava espaço ao propor que essas questões (a questão servil e a questão de substituição do trabalho escravo) fosse definida pelas unidades federadas de acordo com seus interesses" (COSTA, 1998:143).
} 
(queda do gabinete Zacarias) depois da qual não mais funcionaria a contento o mecanismo de alternância característico do sistema monárquico. Não menos importante foi o sentimento de que $\mathrm{o}$ tributo de sangue fora desproporcionalmente cobrado, pesando significativamente mais sobre o Norte e o Nordeste, foco de profundo descontentamento e de críticas acerbas à Coroa" (COSTA, 1998: 144).

E, dentre outras razões, a Guerra do Paraguai é considerada uma das causas fundamentais da crise política de década de $1870^{39}$ justamente por ter contribuído intensamente na deterioração das finanças públicas, sendo seu período de duração (1865/70) encarado pela autora como um “divisor de águas no endividamento público, determinando um crescimento notável tanto no estoque da dívida quanto no peso do seu serviço sobre as receitas do Estado" (COSTA, 1998:144).

Com isso, a Guerra do Paraguai acabou por acelerar o processo de declínio do Império, ao concluir, junto com a autora, que "o peso crescente assumido pela dívida pública a partir dos anos 70, é a relação a um tempo lógica e explosiva entre o estreitamento da capacidade financeira do Estado e a grita generalizada contra a centralização que se desenvolve no período" (COSTA, 1998:147).

O financiamento desse déficit deu-se, basicamente, por meio de duas formas, (i) pela emissão interna de apólices (que respondeu por aproximadamente $57 \%$ da dívida) e (ii) pela emissão de papel-moeda. Esta última, em especial, refletiu-se em um sensível aumento do meio circulante à época, aumento este, entretanto, que por pouco tempo durou.

Dessas duas distintas maneiras de financiamento, podemos apontar, na esteira de GRANZIERA (1979), uma paralela e crescente diversificação da economia fluminense e paulista. Enquanto àquela se destinavam as apólices do governo, a esta era destinada grande parte da moeda emitida ${ }^{40}$. Conseqüentemente, pode-se notar uma cristalização da economia fluminense em títulos públicos, propiciando a criação de uma classe de rentistas

\footnotetext{
39 Especificamente quanto à relação entre a Guerra do Paraguai e a crise política da década de 1870 , recomenda-se a leitura de outra obra da autora, dedicada exclusivamente ao tema, intitulada $A$ espada de Dâmocles - O exército, a Guerra do Paraguai e a crise do Império (COSTA, 1996).

40 "(...) o papel-moeda em São Paulo e o título da dívida pública no Rio de Janeiro, ambos gerados pela Guerra do Paraguai, serão, daí em diante, as mais lídimas expressões financeiras de duas economias que começam a diferenciar" (GRANZIERIRA, 1979:101).
} 
interessados na política monetária restritiva ${ }^{41}$. Enquanto isso, a economia paulista se dinamizava, tendo seu crescimento impulsionado ${ }^{42}$.

Por fim, cumpre ressaltar que a política monetária que se seguiu à Guerra do Paraguai, com a finalidade de sanear as contas públicas já tão abaladas pelo conflito, foi marcadamente restritiva. E tal política perduraria até os últimos anos do Império. Com isso, agravavam-se os problemas da falta de liquidez e a escassez do meio circulante.

É nesse contexto que se pode entender o fator interno da crise de 1875 , relevando em importância a chamada "crise de numerário", isto é, a acentuada falta de meio circulante. Tal crise produziu a concordata de diversos estabelecimentos bancários, dentre os quais se destacam os Bancos Alemão e Nacional, bem como a Casa Mauá. Tais concordatas provocaram, ainda, grande corrida aos estabelecimentos bancários, abalando toda a estrutura financeira brasileira (PIÑEIRO, 1996:48).

Assim, os interesses dos detentores do capital bancário vieram a se somar às preexistentes demandas do setor agrícola por crédito, ambos propugnando pela criação de organismos próprios de financiamento agrícola. Tal pressão acabou por fazer o governo aprovar o decreto legislativo $\mathrm{n}^{\circ} 2.687$, de 06 de novembro de 1875 , autorizando a fundação de bancos de crédito real e engenhos centrais. Esses estabelecimentos careciam de recursos para o exercício de suas funções. Nesse decreto ficou estabelecido que o governo concorreria com 50.000 contos para a formação do capital desses bancos. Tendo em vista os estreitos orçamentos com que o governo trabalhava à época, surgiu forte discussão a respeito de onde o Tesouro conseguiria tal valor (PIÑEIRO, 1996:49).

As referidas medidas governamentais voltaram a elevar o endividamento do Tesouro, o que levou o Banco do Brasil a retornar, a partir de 1877, às operações com apólices da dívida pública, a fim de captar recursos. Isso refletiria na atuação da Carteira

\footnotetext{
41 “O que ocorria era uma crescente cristalização do capital fluminense na forma de títulos públicos. Surgia daí uma classe de rentistas cujos interesses se relacionariam a uma política monetária restritiva. Os juros altos associados à baixa circulação monetária e à escassez de crédito aumentariam suas rendas, a despeito dos efeitos negativos que provocariam na economia" (BOTELHO JR , 2002:20).

${ }^{42}$ Discordando da posição de Granziera, Maria Barbara Levy entende que o Rio de Janeiro, como principal centro financeiro e comercial do país, sempre sofreu com a drenagem de dinheiro, e qualquer alta nas taxas de desconto dos títulos era suficiente para que os juros se elevassem e os negócios parassem por falta de dinheiro. Além disso, "apenas 14 horas, por via férrea, separavam as duas cidades, e que o Rio de Janeiro mantinha com São Paulo ativo comércio de produtos de subsistência, além do que as exportações de ambas as províncias resumiam ao mesmo produto: o café. Portanto, não era tão pequeno o contato entre elas, a ponto de constituírem ilhas econômicas. Ao contrário, São Paulo permaneceria na órbita do circuito monetário regional do Rio de Janeiro" (LEVY, 1995:92-93).
} 
Hipotecária, que, em 1878, manteve o volume de 25.000 contos, mas apenas para renovação dos empréstimos já existentes.

As crescentes dificuldades enfrentadas pelo Tesouro aumentaram o poder dos bancos, que passaram a pressionar o governo. Em 1879, com a finalidade de salvar as finanças públicas, governo imperial e Banco do Brasil firmam um novo acordo ${ }^{43}$, que acabaria por fazer retroceder a atuação da Carteira Hipotecária, pois as operações de financiamento do Tesouro possibilitadas pelo novo acordo eram muito mais rentáveis que o $1 \%$ daquela linha de operação. Inclusive, a diretoria do Banco decidiu que não mais se realizasse o lançamento das letras hipotecárias previstas para aquele ano, e tal postura manteve-se durante toda a década (PIÑEIRO 49:1996).

Em meio a isso, mantinha-se como uma das principais reclamações dos proprietários de terras a falta de crédito agrícola no país. Isso fica bastante evidente ao analisar o Congresso Agrícola de 1878.

Realizado na cidade do Rio de Janeiro em julho de 1878, o Congresso Agrícola organizado pelo governo imperial foi o primeiro do gênero no país. Tal evento teve repercussão nacional e reuniu agricultores das principais regiões brasileiras produtoras de café. Segundo representantes do governo, o objetivo da realização do Congresso era encontrar formas de auxiliar a lavoura do país e impulsionar seu desenvolvimento. Isso seria feito por meio de um questionário a ser respondido pelos participantes.

Como forma de facilitar o trabalho dos congressistas, assim como de conduzir a direção das discussões, foi apresentada pelo governo aos participantes do Congresso Agrícola do Rio de Janeiro uma lista de perguntas que retrata tanto os principais problemas enfrentados pela lavoura brasileira no período quanto os interesses em jogo:

I) Quais as necessidades mais urgentes e imediatas da grande lavoura?;

II) É muito sensível a falta de braços para manter ou melhorar e desenvolver os atuais estabelecimentos da grande lavoura?;

\footnotetext{
${ }^{43}$ PIÑEIRO (49:1996) descreve da seguinte forma este novo acordo:

"Pelo novo contrato estabelecia-se uma conta-corrente do Tesouro, até o limite de 10.000.000\$, concentrando-se ali os recursos necessários para gerir toda a dívida flutuante, a prazos mais ou menos longos. O Banco forneceria ainda cambiais para que o estado pudesse cumprir seus encargos e voltava a se incumbir dos serviços a cargo da caixa de amortização. Em troca, o governo passaria a depositar no Banco todos os saldos disponíveis na Tesouraria Geral, Alfândega da Corte e Recebedoria do Rio de Janeiro, para crédito na referida conta, o que significava, na prática, que voltava a deter o gerenciamento dos recursos do Estado e da dívida pública".
} 
III) Qual o modo mais eficaz e conveniente de suprir essa falta?;

IV) Poder-se-á esperar que os ingênuos, filhos de escravas, constituam um elemento de trabalho livre e permanente na grande propriedade? No caso contrário, quais os meios para reorganizar o trabalho agrícola?;

V) A grande lavoura sente carência de capitais? No caso afirmativo, é devido este fato à falta absoluta deles no país ou à depressão do crédito agrícola?;

VI) Qual o meio de levantar o crédito agrícola? Convém criar estabelecimentos especiais? Como fundá-los?;

VII) Na lavoura têm-se introduzido melhoramentos? Quais? Há urgência de outros? Como realizá-los?

Dentre esses principais problemas, pode-se notar, nos itens V e VI, a preocupação com o crédito agrícola. Em obra monográfica sobre o Congresso Agrícola de 1878, ao tratar da atenção dispensada no Congresso ao problema de crédito, SIMÃO relata:

"A possibilidade de obtenção de capitais e os meios de prover a lavoura dos mesmos foram, logo após a questão da imigração, os temas mais presentes nos textos e discursos do Congresso Agrícola do Rio de Janeiro. O crédito agrícola era visto ou como a maior necessidade da lavoura, com o qual tudo mais se resolveria, inclusive a questão da mão-de-obra, ou como a segunda maior necessidade logo após, é claro, do aumento no número de braços. Em geral, a solicitação se resumia, assim como seria feito no Recife, a empréstimos a juros módicos e longos prazos de amortização" (SIMÃO, 2001:22-23).

Entretanto, a despeito da convocação do Congresso Agrícola de 1878, toda a boa vontade demonstrada pelo governo na questão do crédito agrícola esbarraria num obstáculo contra o qual nem mesmo a enorme pressão do setor agrícola conseguiria prevalecer: a política monetária saneadora e restritiva.

\subsection{A política monetária restritiva dos anos 80 .}


Como já se disse, essa política monetária restritiva adotada pelo governo se manteria praticamente a mesma durante quase toda a década de 80 . Ao comentar a política monetária desse período, BOTELHO JR. sentencia que "a década de 80 foi, sem margem a dúvidas, o período em que a política monetária apresentou-se mais restritiva durante a segunda metade do século XIX" (2002:26).

A incessante busca governista pela conversibilidade e o câmbio valorizado são elementos com os quais se pode remontar boa parte da política econômica adotada durante toda a década de 80 . Tal postura governamental se faria sentir, basicamente, através de duas conseqüências: (i) em relação ao exterior, o endividamento externo ${ }^{44}$; e (ii) em relação à economia interna, a escassez do meio circulante ${ }^{45}$. À presente pesquisa esta última conseqüência interessa especialmente.

Atribuída por alguns como uma conseqüência da preocupação do governo em “satisfazer às exigências dos seus credores no exterior" (LUZ, 1960:90), a escassez do meio circulante representaria uma significativa diminuição da oferta de crédito interno.

Em maio de 1885, as casas bancárias do país novamente se encontravam com problemas de encaixe. Embora tais problemas não fossem comparáveis em magnitude aos da crise de $1875^{46}$, foram suficientes para mover o governo, na tentativa de resolvê-los, a aprovar a lei de 18 de julho de 1885 .

Segundo CALÓGERAS, essa lei propunha "o retôrno à mesma política adotada pelo Parlamento Conservador a fim de atender aos inconvenientes da falta de flexibilidade do papel-moeda" (1960:173). Trata-se de referência à lei de 29 de maio de 1875, a qual permitia ao Tesouro o recurso a emissões temporárias independentemente de autorização legislativa. Ou seja, por meio da lei de 18 de julho de 1885, pretendia-se aumentar a

\footnotetext{
44 "Enquanto o câmbio deve ser mantido valorizado para facilitar o pagamento dos encargos da dívida, é necessário adquirir divisas através de endividamento para mantê-lo neste patamar. Em outras palavras, se tomarmos este movimento em sua forma pura, não é difícil visualizar que se trata de um círculo vicioso cujo resultado final é o endividamento cada vez maior do Estado. Na década de 1880, a dívida externa foi duplicada, passando de aproximadamente 15 milhões de libras para 30 milhões de libras". (BOTELHO JR., 2002:25).

${ }^{45}$ Constatando a escassez do meio circulante no período (1880-1889), BOTELHO JR. observa que, enquanto a estimativa do produto interno teria aumentado $18,5 \%$, o meio circulante não só não havia acompanhado esse crescimento, como ainda viria a decrescer sensivelmente no mesmo período. E arremata o autor: "pode-se imaginar o quanto a política monetária prezou a escassez dos meios de pagamento nos anos oitenta" (2002:26-27).

${ }^{46}$ CALÓGERAS (1960, p. 172 e 174).
} 
liquidez por meio da autorização ao Tesouro para emissões ${ }^{47}$. Com efeito, a lei, de apenas dois artigos, permitia ao governo a emissão de até 25.000 contos. No entanto, na prática, a medida mostrou-se pouco efetiva, não sendo capaz de resolver o problema da escassez do meio circulante.

O problema de circulação monetária viria ainda a ser agravado em maio de 1888 , com a abolição da escravatura, que teve como conseqüência a consolidação do regime de mão-de-obra assalariada, o que, por sua vez, aumentaria ainda mais a demanda por moeda, visto que agora seria necessário maior numerário para que os pagamentos dos salários fossem realizados.

Analisando essa nova necessidade de numerário, com base em Delfim Netto, FRANCO a explica da seguinte forma:

“A disseminação dos pagamentos de salários por certo alterava as necessidades de capital de giro das fazendas de café, uma vez que, antes de 1888, os recursos financeiros necessários para o custeio da fazenda eram relativamente pequenos, pois a parte mais importante desse custeio - que era o pagamento da mão-de-obra praticamente não existia" (1987:24-25).

\subsection{A política econômica do Gabinete Ouro Preto.}

Conjunturas políticas somadas ao cenário econômico acabaram por desencadear a queda de João Alfredo da Presidência do Conselho. Tradicionalmente ligado à propriedade territorial, o Partido Conservador, ao qual pertencia João Alfredo, se encontrava enfraquecido pela discussão em torno da questão servil, especialmente quanto à polêmica que cercava a indenização ou não dos ex-proprietários de escravos, questão sobre a qual se dividiam os próprios conservadores. A indecisão e a falta de planejamento do governo no tratamento dessa questão serviram para tirar ainda mais força política de João Alfredo. Enfraquecido, João Alfredo fora acusado de advocacia administrativa, por ter ligações de parentesco com um empresário do Rio de Janeiro acusado de enriquecimento ilícito,

\footnotetext{
${ }^{47} \mathrm{O}$ projeto de lei, de autoria do ministro Lafayette, quando ministro da Fazenda, seria defendido em maio de 1885 pelo conselheiro Antônio Saraiva, seu sucessor no ministério, alertando para a proximidade do fim do semestre, quando ocorriam as liquidações e os pagamentos, o que, forçosamente, aprofundaria o problema da escassez do meio circulante (PACHECO, 1973:203).
} 
supostamente ajudado por sua influência. Tal acusação deu origem a diversas discussões no Parlamento, e João Alfredo, percebendo a delicada situação em que se encontrava, recorreu ao Conselho de Ministros solicitando a dissolução do Congresso. O Conselho, entretanto, negou-lhe tal pedido, e João Alfredo se viu obrigado a sair do governo.

A escolha do novo presidente do Conselho seria marcada pelas múltiplas facetas da crise política, isto é, além dos freqüentes embates dos parlamentares entre si, pelos conflitos entre governo e militares e, sobretudo, pelo preocupante crescimento do movimento republicano. Esse movimento assombrava o Império, tendo em vista a debilitada saúde do Imperador, o reduzido prestígio de sua herdeira e a menoridade de seu herdeiro (FRANCO, 1987:73-74).

Assim, o Imperador buscou manter o próximo gabinete nas mãos do Partido Conservador, por possuir este ampla maioria no Parlamento. Entretanto, percebeu que as divisões internas do partido inviabilizavam tal idéia, havendo o Imperador de recorrer à minoria liberal para a formação do gabinete. Após um convite ao Conselheiro Saraiva, que o recusou alegando saúde debilitada, o Imperador convida à Presidência do Conselho o Visconde de Ouro Preto, que a assumiria em 07 de junho.

Note-se, no entanto, que também o Partido Liberal não estava isento de divisões, como se pode ver pelo Congresso do partido, realizado dias antes da queda de João Alfredo. Nesse Congresso, os dissensos entre os liberais, especialmente em relação à questão federativa ${ }^{48}$, acabaram por distanciar do partido Rui Barbosa, o qual acabou se aproximando dos militares e fez tenaz oposição ao governo de Visconde de Ouro Preto.

Com a ascensão do Gabinete Ouro Preto, último Gabinete Imperial, em meio às muitas dificuldades políticas a serem por ele enfrentadas ${ }^{49}$, as atenções do governo se

\footnotetext{
${ }^{48}$ Durante o Congresso Liberal, uma comissão de membros elaborou um programa de ação partidária, que mais tarde viria a se transformar, sem muitas modificações, no programa de governo da gestão Ouro Preto. Rui Barbosa participou dessa comissão, mas divergiu do documento apresentado em alguns pontos, mas, principalmente, no que se referia à questão da autonomia regional. Tendo uma proposta de cunho autonomista bastante mais acentuado do que aquela apresentada pela comissão, Rui Barbosa fez questão de apresentar voto em separado, dizendo:

"Sou completamente pela forma federativa, considerando o sistema do questionário, como transição, que de modo nenhum satisfaz às atuais aspirações do país, nem contrapõe ao movimento republicano um regime capaz de neutralizá-lo, estabelecendo descentralização na medida indispensável aos direitos do interesse local" (AFONSO CELSO, 1935:43).

${ }^{49}$ Pode se ter uma idéia da dimensão dessas dificuldades ao se saber que, em 11 de junho, durante a sessão em que Ouro Preto apresentava seu programa de governo, após lido este, o deputado conservador Castro Gomes apresentou uma moção de desconfiança, que seria aprovada por 79 votos contra 20. No entanto, "ao que tudo indicava, o Visconde parecia já ter garantido a possibilidade de dissolução do Congresso, o que seria bastante normal numa situação onde o Ministério era liberal e o Parlamento esmagadoramente conservador"
} 
dividiriam basicamente entre duas principais preocupações. A primeira, de viés político, seria a necessidade de angariar aliados políticos para fazer frente ao movimento republicano $^{50}$. A segunda, de viés econômico, consistia na equalização do problema da escassez do meio circulante e da falta de crédito agrícola em parte dela decorrente (BOTELHO JR., 2002:29).

Com relação à política econômica, pode-se ver na publicação de um periódico da época, intitulado A Província de São Paulo, como era bastante grande a preocupação com a escassez do meio circulante:

\begin{abstract}
"De um momento para outro, póde apparecer falta de meio circulante, tornando-se diffícil a crescente expansão da actividade nacional. (...) $\mathrm{O}$ augmento rapido do consumo nos mercados internos, a necessidade de pagamento de salário do maior número de trabalhadores e em moeda, o desenvolvimento da actividade industrial, tudo isso determina novas necessidades e maior procura do numerario para lhes fazer face"
\end{abstract}

No que tange a esse problema econômico, duas foram as principais medidas do Gabinete Ouro Preto: a reforma bancária e a concessão dos polêmicos auxílios à lavoura.

É interessante ver, como nota FRANCO, que ambas "são medidas coerentes entre si", indo "de encontro aos problemas (...) referentes ao baixo grau de desenvolvimento do sistema bancário, agravados pelas condições econômicas e políticas do segundo semestre de 1889" (1987:76). Vejamos, na esteira desse autor, brevemente cada uma dessas medidas para notar a raiz comum entre elas.

(FRANCO, 1987:75). Ouro Preto pediu a dissolução do Congresso e, em 15 de junho, o Conselho de Estado aprova tal pedido, com apenas dois votos contrários, dos conselheiros Andrade Figueira e Paulino de Souza, que não estavam conformados com a solução proposta pelo Governo para o problema da indenização dos exproprietários de escravos. Em 17 de junho, o Congresso era efetivamente dissolvido, e as eleições realizadas em 31 de agosto dariam ampla maioria ao Governo.

${ }^{50} \mathrm{Na}$ mesma seção de leitura de seu programa de governo de 11 de junho, o próprio Visconde de Ouro Preto referiu-se da seguinte forma à propaganda republicana:

“(...) mister não desprezar essa torrente de idéias falsas e imprudentes, cumprindo enfraquecê-la, inutilizá-la, não deixando que se avolume. (...) chegaremos a esse resultado empreendendo com ousadia e firmeza largas reformas na ordem política, social e econômica (...) reformas que não devem ser adiadas para não se tornarem improfícuas” Discurso do Senado de 11.06.1889.

${ }^{51}$ A Província de São Paulo, 7 de fevereiro de 1888, no 3.856. 


\subsubsection{Os auxílios à lavoura.}

Primeiramente, cumpre esclarecer que o impulso inicial à concessão do auxílio à lavoura havia sido dado ainda na Presidência do Conselho de João Alfredo. Com efeito, a iniciativa partiu do Conselho Diretor do Banco do Brasil, que, em 23 de maio de 1888, apresentou uma proposta muito semelhante àquela apresentada em 1871: o banco sugeria a redução do resgate de suas notas para que pudesse recomeçar as operações hipotecárias.

Aproximadamente dois meses depois, em 25 de julho de 1888, o Presidente do Conselho profere um discurso no qual anuncia os resultados da negociação, no qual ele dizia não só se preocupar em "organizar o crédito real e hipotecário de modo definitivo e permanente, como também em acudir com remédios prontos e eficazes às urgências atuais da mesma lavoura", concluindo que "tais remédios, de natureza urgente e temporária, dependiam de achar o governo um intermediário em condições, já de responder pela restituição integral do dinheiro emprestado pelo Tesouro, já de fazer justa distribuição dos auxílios aos lavradores que dele necessitassem". Ou seja, em seu discurso, o Presidente João Alfredo dizia-se duplamente comprometido com o problema do crédito agrícola: de um lado, pretendia fazer uma mudança estrutural ${ }^{52}$, organizando-o de modo "definitivo e permanente"; de outro, acreditava que a urgência dos problemas de crédito não comportava espera a essa reestruturação, sendo necessária, conseqüentemente, uma medida paliativa, "temporária", mas, desde logo, efetiva. Essa medida seria a concessão dos auxílios à lavoura.

Para tanto, como se pode notar no discurso de João Alfredo, ele precisaria de um intermediário. E é nesse ponto que os bancos se vêem, nas palavras de FRANCO, "envolvidos na discussão que era nada menos que o epicentro da crise política em curso". Isso porque o Presidente do Conselho viu na proposta do Banco do Brasil uma excelente oportunidade para resolver duas questões de uma só vez.

A primeira e mais imediata seria a realização, por meio da concessão de crédito, de uma espécie de "indenização indireta", ou seja, uma compensação aos ex-proprietários de escravos pela abolição.

\footnotetext{
${ }^{52}$ João Alfredo realmente havia apresentado em 26 de junho um projeto de constituição de bancos de crédito real, que teriam suas letras hipotecárias garantidas até 5\%, seguindo em grande parte o modelo da lei de 1875, com a substancial diferença de não se restringirem às letras no exterior. No entanto, com sua queda, tal projeto não chegou sequer a ser analisado pelo Senado.
} 
A segunda seria o governo livrar-se da árdua tarefa de distribuir os benefícios entre os lavradores. Nesse mesmo ponto, ao se livrar desse ingrato papel, o governo ainda conseguiria, ao interpor o banco aos lavradores na realização dos empréstimos, garantir que os recebesse somente "a lavoura que tivesse condições de vida", isto é, ao aplicarem critérios bancários no repasse do dinheiro, os bancos somente emprestariam àqueles que apresentassem solvabilidade, retirando, assim, a obrigação do governo de repassar dinheiro a quem não poderia pagá-10 ${ }^{53}$, realizando uma distribuição seletiva de crédito.

Pouco mudaria a posição do Gabinete Ouro Preto com relação aos auxílios à lavoura $^{54}$. De uma forma geral, os contratos de empréstimos, que se assemelhavam bastante entre si, consistiam no adiantamento de determinada quantia aos bancos sem cobrança de juros, com a contrapartida destes se encarregarem de empregar o dobro da quantia adiantada em empréstimos à agricultura, a juros de $6 \%$ a prazos variáveis ${ }^{55}$.

Os compromissos criados pelo governo com esses empréstimos seriam levantados por meio do decreto de 27 de agosto de 1889, que lançava em títulos da Dívida Pública aproximadamente 109 mil contos. Tais títulos pagariam juros em ouro, o que, com a subida do câmbio em dezembro de 1889, levou o governo a ter perdas na ordem de quase 10 mil contos, segundo estimativa de Rui Barbosa ${ }^{56}$.

À medida que ganhavam maior dimensão, os auxílios à lavoura passam a chamar a atenção de diversos setores sociais da época, levantando-se contra eles diversas acusações. Nesse ponto, destaca-se o papel da imprensa na discussão dos auxílios, embora, por vezes, tenha parecido faltar-lhe neutralidade.

Surgiu a acusação, liderada em grande parte pelo então redator do Diário de Notícias Rui Barbosa, de que os recursos adiantados aos bancos a título de auxílio à lavoura não se destinavam efetivamente a estas. O próprio Visconde de Ouro Preto, por sua conta, procurou se defender, reunindo dados que buscavam comprovar que o destino dos recursos repassados pelo governo era a lavoura.

\footnotetext{
${ }^{53}$ Pode-se notar que essa medida governamental selaria a decadência da cafeicultura do Vale do Paraíba, que, encontrando-se em crise, não conseguiria se dinamizar a fim de fazer jus aos auxílios.

54 "O Visconde de Ouro Preto tornou práticas essas considerações ao desenvolver os auxílios na forma com que foram efetuados por João Alfredo, celebrando contratos no valor de 172 mil contos" (FRANCO, 1987:83).

${ }^{55}$ Cf. FRANCO (1987:161), os prazos variavam de cinco a quinze anos para os contratos sobre hipotecas, de um a três anos para aqueles sobre frutos pendentes e penhores agrícolas e de um a cinco anos para os que se dessem sobre cauções de títulos.

${ }^{56}$ Relatório do ministro da Fazenda (1891:298).
} 
Outra crítica constantemente feita aos empréstimos seria o caráter político dos auxílios. Sustentava-se que ocorreria, na verdade, não uma seletividade do crédito atendendo a critérios de viabilidade, mas, sim, discriminação com caráter eleitoreiro. Também Rui Barbosa defendeu essa idéia, sustentando que os "benefícios desse sistema experimentaram-se apenas na vitória eleitoral do Gabinete" (BARBOSA, 1892:11).

Uma última acusação à política dos auxílios à lavoura seria a de a ela atribuir o impulso originário à especulação na Bolsa de Valores, à qual se deve, em boa parte, a crise do Encilhamento. No dia 18 de dezembro de 1889, o Jornal do Commercio, por exemplo, dividindo as causas da crescente especulação entre a reforma bancária de 6 de junho, que veremos a seguir, e os auxílios, dizia que os bancos beneficiados "gozavam de capital gratuito, que muito aumentaria os lucros a dividir pelos acionistas", dizendo ainda que "a verba dos auxílios oficiais à lavoura, estando ainda longe de esgotar-se, convinha fundar novos bancos, cujas ações seriam evidentemente subscritas sem demora, pela certeza, que tinham os subscritores, que elas seriam dentro em poucos dias procuradas com prêmios", completando que "o furor para organizar bancos foi agudo, estimulado máxime pelos favores oferecidos aos bancos intermediários nos chamados 'auxílios à lavoura"” (BARBOSA, 1892:23).

Aliás, a respeito dessa acusação, o próprio Visconde de Ouro Preto mais tarde admitiria que "não contestaremos que a especulação, ou antes agiotagem (...) começou a desenvolver-se na praça do Rio de Janeiro, ainda sob o Império (...)" (OURO PRETO, 1899:55).

\subsubsection{A reforma bancária de 1888 .}

Ao lado dos auxílios à lavoura, outra medida fundamental da política econômica do Gabinete Ouro Preto seria a reforma bancária.

Antes de vermos como a reforma bancária foi realizada, vejamos rapidamente em que ela consistia. Como vimos anteriormente (item 2.5), a política monetária fortemente restritiva dos anos 1880 teve como conseqüência interna a forte escassez do meio circulante, escassez essa ainda agravada pela abolição da escravidão em maio de 1888 . Com isso, o crédito interno sofreu forte recessão. Com medidas iniciadas pelo Gabinete João Alfredo e aprofundadas pelo Gabinete Ouro Preto, o governo entendeu ser a reforma 
bancária a solução para a escassez de meio circulante no país. Tal reforma seria realizada justamente com este objetivo.

Em linhas gerais, a reforma bancária de 1888 consistia na criação de bancos que poderiam emitir notas conversíveis em moeda imperial, as quais deveriam ser garantidas com o depósito de títulos da dívida pública e não poderiam exceder a quantia depositada em títulos. As emissões do Tesouro seriam recolhidas ante a emissão destes títulos. Os bancos substituiriam os títulos do governo por ouro. Assim, tratava-se de um processo gradual em que, num primeiro momento, as notas de banco seriam conversíveis em títulos do governo; num estágio intermediário, as notas seriam conversíveis, parte em ouro, parte em títulos; e, na etapa final, quando todas as notas do Tesouro fossem recolhidas, as notas de banco seriam plenamente conversíveis em ouro. Desta maneira, com tal reforma a regra da conversibilidade, incessantemente seguida à risca durante toda a década de 1880, era mitigada e flexibilizada, pois, embora a etapa final do processo permanecesse sendo a conversibilidade em ouro de todas as notas emitidas, haveria etapas intermediárias em que a conversibilidade não estaria diretamente presente.

Visto este breve esboço da reforma bancária de 1888, vejamos agora como se deu o debate legislativo que a cercou e como ocorreu seu processo de implementação. Para tanto, será necessário retornarmos um pouco ao final do Gabinete João Alfredo, quando foram tomadas as primeiras medidas visando a reforma bancária.

Em junho de 1888 surgiu um projeto de reforma bancária. O debate legislativo em torno desse projeto fez com que o Congresso novamente se tornasse um palco de debate entre metalistas e antibulionistas. Enquanto estes últimos, autores do projeto, visavam à promoção da expansão monetária, aqueles, representados especialmente pelas Comissões de Fazenda e Legislação, pretendiam refrear esse ânimo, vinculando as emissões bancárias à incineração de uma quantidade igual de notas do Tesouro (FRANCO, 1987:62).

Buscando uma alternativa a este impasse, os autores do projeto propuseram uma solução intermediária e conciliatória ${ }^{57}$, a qual, embora tenha enfrentado resistência tanto

\footnotetext{
${ }^{57}$ Os autores cedendo à pressão metalista, propuseram que os bancos fossem autorizados a emitir bilhetes conversíveis em ouro, na base do triplo do valor do lastro metálico. Além disso, em discurso no Senado no dia 14 de junho de 1888, o Visconde de Cruzeiro, representando os autores do projeto, assim de manifestou:

“(...) querendo prestar homenagem ao parecer das ilustradas comissões, tanto quanto for possível sem prejudicar o fim principal do projeto, que é, como fica dito, obviar a insuficiência do meio circulante, pensam os autores do projeto que se pode atender à (...) emenda da comissão, determinando-se que seja incinerada somente a metade do papel-moeda com que for pago pelos bancos o preço das apólices, substituindo a
} 
dos bulionistas quanto de seus opositores ${ }^{58}$, acabou sendo aprovada, se transformando no Decreto $n^{0} 3.043$, de 24 de novembro de 1888.

Tendo sido a discussão parlamentar do decreto marcada por um longo e intenso debate, e havendo ainda o receio de forte oposição de diversos setores da sociedade, o decreto deixou muitos de seus aspectos polêmicos para serem trabalhados quando de sua regulamentação. Tal adiamento não foi suficiente para evitar ácidas críticas à lei de novembro de $1888^{59}$.

Independentemente das críticas, nota-se que a regulamentação da lei passou então a ter grande relevância. Embora a regulamentação competisse originariamente ao Ministro da Fazenda, cargo então ocupado pelo Conselheiro João Alfredo, este abriu mão dela, visando evitar acirrar ânimos, tendo em vista o enfraquecimento enfrentado por seu partido político, o Partido Conservador, em razão da questão servil.

Assim, incumbiu aos próprios autores do projeto sua regulamentação, que acabaram divergindo em alguns pontos. O principal deles foi a discordância quanto à conveniência de se estabelecer ou não uma limitação às emissões com base metálica de cada instituição emissora. De um lado, o Visconde de Cruzeiro era favorável ao estabelecimento de uma limitação individual das emissões, temendo o monopólio natural de um grande banco e entendendo que a lei deveria coibir a existência de tal banco, pois, caso contrário, a competividade no sistema bancário estaria prejudicada. De outro lado, aproximaram-se Visconde de Ouro Preto e Lafayette, entendendo que não deveria haver limitação individual às emissões, não havendo qualquer problema se um grande banco se criasse, desde que ele resultasse da livre iniciativa e do processo ordinário de competição bancária, arrebatando com a frase "a liberdade corrige tudo"

A questão foi superada quando, com a intervenção da seção de Fazenda do Conselho de Estado, prevaleceu a opinião do Visconde de Cruzeiro, entendendo-se

aplicação da outra metade ao resgate das apólices de 5\%" (ANDRADA, 1923:180).

58 "De qualquer modo, a coexistência, no projeto, de disposições acerca da emissão sobre títulos e da emissão sobre metal despertou objeções tanto dos bulionistas quanto de seus opositores. O Jornal do Commercio, por exemplo, observou que, com a inclusão das emendas sobre emissão metálica, o projeto tornou-se "uma medida incongruente, em que todos os sistemas foram justapostos e nenhum definitivamente estabelecido"” (FRANCO, 1987:64).

${ }^{59}$ Para se ter uma idéia do tom das críticas recebidas pela Lei de 24 de Novembro de 1888, basta notar como Carlos Inglêz de Sousa, um contemporâneo da lei, a ela se referia, dizendo tratar-se de uma "lei esdrúxula, imperfeita e nociva, como tantas outras" (SOUZA, 1924:213).

\footnotetext{
${ }^{60}$ Relatório do Ministro da Fazenda (1889:28).
} 
inadequada a criação de um grande banco emissor e estabelecendo-se uma limitação de emissões a cada instituição bancária (FRANCO, 1987:66).

Após a regulamentação do decreto, verificou-se um espantoso desinteresse e desuso da utilização dos mecanismos de emissão viabilizados pela lei. Tanto que, em maio de 1889, comentando tal desuso, o Ministro da Fazenda João Alfredo declarou em seu relatório:

\begin{abstract}
“(...) lei e seu regulamento não foram devidamente compreendidos ou não satisfizeram a expectativa pública. O governo, que tem tido algumas propostas e planos para o resgate do papel-moeda e para criação de grandes bancos, não recebeu um projeto sequer para a organização de companhias emissoras de bilhetes ao portador, garantidos por apólices" ${ }^{\prime 61}$.
\end{abstract}

Atribui-se boa parte deste desinteresse à limitação estabelecida pelo regulamento à emissões de cada instituição bancária, pois, ao se impedir a concentração das reservas metálicas em grandes bancos, dispersavam-se as reservas bancárias e "com a fragmentação das reservas, nenhum banco, a princípio, teria peso no mercado cambial e, em conseqüência, não poderia haver uma ação decisiva no mercado de câmbio no sentido de preservar a estabilidade da taxa de paridade. Sem esse tipo de ação, indiscutivelmente, nenhum banco se proporia a fazer emissões conversíveis" (FRANCO, 1987:68-69). Aliás, na exposição de motivos do regulamento que, mais tarde, viria a substituir este que ora se discute, o próprio Visconde de Ouro Preto atribui exatamente a esse aspecto o fracasso do regulamento de janeiro.

Menos de um mês após ter assumido a Presidência do Conselho de Ministros, Ouro Preto promulgou um novo regulamento da lei de 24 de novembro de 1888, em substituição ao regulamento de 5 de janeiro de 1889. A primeira característica interessante do regulamento de julho era que, ao contrário do de janeiro, ele regulava quase que exclusivamente a emissão metálica, o que de certo modo mostrava o desinteresse do governo pela emissão sobre apólice. Além disso, como vimos, o regulamento de janeiro de

\footnotetext{
${ }^{61}$ Relatório do Ministro da Fazenda (1889:29).
} 
1889, após algumas divergências entre seus autores, em despeito da opinião de Visconde de Ouro Preto e Lafayette, fixou uma limitação à emissão individual dos bancos. Como não era de se estranhar, a nova regulamentação removeu quaisquer limites à emissão e atribuiu, em sua Exposição de Motivos, às limitações a missão a causa do fracasso do regulamento anterior.

Como conseqüência da remoção de limitação individual à emissão, logo se formou um grande estabelecimento bancário disposto a emitir sobre base metálica: o Banco Nacional do Brasil. Formado em 19 de setembro de 1889, com um capital de 90 mil contos, tal banco derivava do Banco Internacional ${ }^{62}$, extinto quando da criação deste novo banco, de propriedade do Visconde de Figueiredo, que agia como uma espécie de mentor financeiro de Ouro Preto, sendo este diversas vezes acusado de prestar àquele favores políticos e econômicos.

Depois de constituído, além de contar com a sociedade do poderoso banco francês Banque de Paris et des Pays Bas, o Banco Nacional passou a ser o depositário das reservas metálicas do Tesouro no Brasil. Em 02 de outubro de 1889, o banco assina com o Tesouro um contrato pelo qual se relativizava a conversibilidade metálica de suas emissões, por meio de uma cláusula de termos vagos e imprecisos ${ }^{63}$, que garantia que, em casos de "guerra, revolução, crise política ou financeira" excetuar-se-ia a conversibilidade metálica das emissões, sendo a troca providenciada pelo governo, "como fosse mais conveniente"

\footnotetext{
${ }^{62}$ FRANCO descreve da seguinte forma o Banco Internacional:

"O Banco Internacional era um banco de importância em depósitos e descontos comerciais, mas não tanto quanto o Banco do Brasil e alguns outros. Era, todavia, o banco brasileiro que mais operava em negócios cambiais. O Banco Internacional fora fundado em 1886 especificamente com esse propósito e assumiu rapidamente uma posição proeminente no mercado de câmbio face a algumas vantagens de que desfrutava. Figueiredo tinha alguma experiência como exportador de café, tinha dois sócios ingleses, uma sucursal em Londres e estreitas ligações com banqueiros parisienses, notadamente com o Banque de Paris et des Pays Bas. Além disso, a posição do Banco Internacional no mercado de câmbio viu-se fortalecida pela diminuição das operações cambiais do Banco do Brasil, que se viu pressionado pelos seus acionistas, insatisfeitos com os prejuízos sofridos em tentativas de estabilização cambial no início da década de oitenta" (1987:92).

${ }^{63} \mathrm{O}$ texto integral da cláusula dispunha:

"Os bilhetes do Banco seriam sempre trocados, à vista, por moeda de ouro, ao câmbio de 27, salvo os casos de guerra, revolução, crise política ou financeira, em que o governo providenciaria quanto ao troco, como fosse mais conveniente", transcrito em (ANDRADA, 1923:214).

${ }^{64}$ Bastante obscuro o processo de concessão dessa garantia de suspensão da conversibilidade, uma vez que o Banco Nacional, que teve seus estatutos aprovados em decreto de 28 de setembro, assinou o decreto no primeiro dia em que efetivamente funcionava, 02 de outubro. Além disso, em 15 de setembro, muito antes, portanto, da aprovação dos decretos do Banco Nacional, uma revista francesa já noticiara um acordo entre o governo brasileiro e o Banque de Paris et des Pays Bas, cujos termos eram idênticos ao contrato de 02 de outubro, segundo relatado pelo Diário de Notícias de 13.10.1889, em "As Grandes Operações”.
} 
Ao criticar a cláusula, comentando a imprecisão dos casos em que seria suspensa a conversibilidade, Rui Barbosa afirma que "uma corrida contra o grande estabelecimento de emissão nacional assumiria, com pouco esforço, as proporções de uma 'Crise Financeira', e imediatamente os seus bilhetes perderiam o direito à conversão à vista em moeda metálica (...) e como as corridas haviam de ser o resultado ordinário das baixas do câmbio - em um país onde estas são quase perenes, claro está que não era a circulação metálica, mas a continuidade do papel inconversível, que o contrato de 02 de outubro vinha efetivamente implantar" (BARBOSA, 1892:19-20).

O contrato de 02 de outubro previa ainda que, entre os anos de 1889 e 1894, o Banco Nacional se obrigava a retirar de circulação, gradativa e crescentemente, todo o papel-moeda do Tesouro, o qual se comprometia, em contrapartida, a não emitir enquanto houvesse o Banco Nacional. Tendo em vista que a única limitação de prazo à existência do Banco Nacional seria aquela instituída pelo $\S 5^{\circ}$ do art. $1^{\circ}$ da lei de 24 de novembro, segundo o qual o prazo de duração dos bancos emissores não excederia 20 anos, o comprometimento do Tesouro em não emitir ganhava proporções enormes.

Não por outra razão, fortes críticas foram dirigidas a este compromisso do Tesouro. Também neste aspecto pode-se destacar a contundente oposição levantada por Rui Barbosa à política econômica do Gabinete Ouro Preto, ao afirmar, no artigo "Nec Plus Ultra" publicado no dia 27 de outubro de 1889 no Diário de Notícias, que "para que um governo renuncie à faculdade de emitir moedas, sob qualquer das suas espécies, ainda que seja a mais anômala e perigosa delas, como o papel-moeda, necessário é que previamente renuncie ao uso da razão", e arremata, "por mais triste que seja a história do curso forçado, em todos os países, ainda naqueles que tragaram até às fezes a taça das calamidades acumuladas pelo seu abuso-, impossível seria desconhecer-lhe a, não diremos só a utilidade, mas a imprescindibilidade fatal em emergências das mais melindrosas na existência dos povos modernos".

Por fim, cabe notar que o Banco Nacional passou a ter uma função híbrida, exercendo, ao lado de suas funções de banco privado, algumas outras funções que poderiam de alguma forma ser consideradas públicas. Além da já mencionada função de depositário das reservas metálicas do Tesouro, os estatutos do Banco Nacional lhe conferiam as 
funções de administrador da Dívida Pública interna e externa ${ }^{65}$. Embora não houvesse nenhuma atribuição formal ao Banco Nacional do controle do mercado monetário, a assunção dessa tarefa seria uma decorrência quase automática do porte por ele ostentado.

Após a instituição do Banco Nacional, e com a decorrente segurança do mercado monetário garantido por seu porte, diversos bancos emissores de pequeno porte começaram a se instalar perifericamente a ele. E, com isso, o sistema bancário nacional passou a se organizar em torno do Banco Nacional, superando, ao menos em parte, a precariedade de outrora.

No entanto, desnecessário dizer que Ouro Preto fracassou em sua tentativa de conter o movimento republicano. E isto justamente quando parecia que a reforma monetária havia se completado. A mudança da conjuntura política decorrente da Proclamação da República fez com que se necessitasse de uma nova reforma monetária.

\footnotetext{
${ }^{65}$ Antes disso, da administração da Dívida Pública interna estava encarregada a Caixa de Amortização, órgão
} do Ministério da Fazenda, e da Dívida Externa, a Delegacia do Tesouro em Londres (FRANCO, 1987:164). 


\section{Cap. 3 - O Governo Provisório e a tentativa de reforma liberal.}

Não se pretende aqui remontar todo o contexto histórico da proclamação e instauração do regime republicano no Brasil, mas parece conveniente uma breve incursão por esse momento histórico, para que se entendam as primeiras medidas adotadas pelo Governo Provisório.

\subsection{A frágil aliança republicana.}

A implantação do novo regime republicano somente foi possível pela realização de uma ampla, porém frágil, aliança, envolvendo diversas camadas da sociedade brasileira. O principal elo formado foi a aliança triangular entre os setores agrários mais avançados, dentre os quais se destacavam os cafeicultores paulistas, os grupos urbanos emergentes (funcionários públicos, militares, profissionais liberais), que faziam as vezes da opinião pública nacional, e os militares de patentes médias. A esses grupos ainda se somavam as poucas oligarquias agrárias regionais que não estavam diretamente envolvidas com o poder no Império, tal como a gaúcha, historicamente republicana.

Assim, isolou-se politicamente o setor agrário conservador, tributário do sistema escravista e ainda esperançoso em receber indenização pela perda da propriedade de seus escravos. Entretanto, o sucesso da consolidação do regime republicano passou a depender dessa instável aliança firmada entre grupos tão pouco coesos, como os latifundiários paulistas e as Forças Armadas ${ }^{66}$. Grupos que pouco mais tinham em comum que um

\footnotetext{
${ }^{66}$ Neste sentido, comentando as diferenças existentes entre estas duas classes:

"Ressaltar essa heterogeneidade é importante também porque, em certo sentido, as forças mais orgânicas que compunham a 'frente' - a cafeicultura paulista e as Forças Armadas - voltavam-se contra o Império com motivações distintas e até antagônicas. Enquanto o bloco oligárquico criticava a centralização monárquica, as Forças Armadas ressentiam-se da incapacidade da Monarquia em criar o principal instrumento de centralização do Estado Moderno: o exército profissional. Esse antagonismo de fundo marcou toda a primeira década da República, muito embora, já na Constituinte, se possa perceber que as oligarquias estavam muito mais coesas em torno do 'seu' projeto do que os militares, que, a despeito de possuírem em torno de $25 \%$ da representação, não logravam conservar a unidade corporativa conseguida no momento do Golpe. Tinham, porém, sua força potenciada pela própria origem militar do regime que introduzia um dado novo no jogo político: a politização aberta dos quartéis e a consagração do seu direito de intervenção na política. Assim é que uma das peculiaridades do processo de mudança do regime consistiu em que contrastando com o episódio 'pacífico' de sua derrubada (o golpe militar sem resistência significativa) as grandes lutas se dariam depois de derrubado o regime, envolvendo a guerra civil, as insurreições militares, a rebelião milenarista, a agitação urbana, o atentado político. Esses conflitos se dariam apenas em parte entre as forças republicanas e os elementos restauradores. Eles iriam travar-se principalmente no interior do propor campo republicano, dada a multiplicidade de "projetos" que o compunham" (COSTA, 1998:153).
} 
inimigo a ser vencido, o setor agrário conservador, com suas resistências à imigração européia e seus anseios indenizatórios.

Aliás, diga-se de passagem, não só a aliança entre os grupos que apoiavam a República era instável, como os próprios grupos não tinham muita coesão interna. Basta ver os poucos interesses compartilhados pelas classes urbanas emergentes, que agregavam militares, funcionários públicos e profissionais liberais.

Note-se que, nos primeiros anos da República, diferentes personagens buscaram assumir os postos de representantes de suas classes, disputando por elas o poder. O militarismo radical jacobino seria representado por Joaquim Floriano, as diferentes vertentes das classes urbanas, por Rui Barbosa, Quintino Bocaiúva e Benjamin Constant, e o setor agrário progressista, por Campos Salles, Prudente de Moraes e Joaquim Murtinho.

\subsection{O vazio político causado pela ausência de um projeto consensual de} governo.

Dessa forma, pela própria falta de coesão dos grupos apoiadores da instalação da República, parece inadequado falar em um projeto consensual do governo republicano ${ }^{67}$, sendo mais apropriada a idéia de existirem, dentro do próprio movimento republicano, diversos projetos de governo. Assim, tão logo proclamada a República, criou-se uma espécie de vácuo político, abrindo-se um espaço de atuação política visto pelos setores urbanos emergentes e por outros setores mais progressistas da sociedade como a possibilidade que necessitavam para implementar as reformas necessárias ao progresso do Brasil.

E, com efeito, as classes urbanas passaram a ter maior espaço de atuação política. Até então relativamente alijadas do contato com o poder, tais classes tiveram a grande maioria dos ministérios do primeiro governo, o que reflete, ao menos em parte, essas condições. Além dos fortes nomes de Rui Barbosa como ministro da Fazenda, de Quintino Bocaiúva no Ministério das Relações Exteriores e de Benjamin Constant no Ministério da

\footnotetext{
67 “A República resultou muito mais do lento processo de decomposição do regime imperial do que de um projeto orgânico e claramente delineado. No espectro ideológico do movimento republicano cabiam concepções muito diversas, que iam da pregação democrática de um Silva Jardim ou de um Lopes Trovão às vagas teses liberais do Partido Republicano Paulista e à Ditadura Republicana apregoada pelo Apostolado Positivista. Além disso, a derrubada do regime se fez sob forma de um golpe militar, em que pesaram decisivamente as demandas específicas da corporação armada" (COSTA, 1998:152-153).
} 
Guerra, quase todos os outros ministros eram pertencentes às classes urbanas, com a exceção de Campos Salles (ministro da Justiça). Pode-se, dessa forma, afirmar que, ainda que as classes agrárias participassem do poder no início da República, essa atuação estaria longe de ser hegemônica. E, talvez, nem mesmo pudesse ser considerada tão forte assim quando comparada às classes urbanas.

\subsection{A tentativa de reforma liberal de Rui Barbosa.}

É nesse contexto que um nome avulta dentre os republicanos, com propostas reformistas liberais para o Brasil. Trata-se de Rui Barbosa. Grande parte da tentativa de reforma por ele buscada correspondia a velhos anseios dos reformistas liberais. Em grossas linhas, sua reforma poderia ser descrita como uma tentativa de revisão das liberalidades com as quais o governo imperial havia brindado o setor agrário conservador, conquanto pudéssemos sopesar que, neste caminho, Rui Barbosa acabasse por praticar uma série de outras liberalidades a outros setores, como o bancário.

Uma das principais maneiras pelas quais o governo imperial havia socorrido os fazendeiros fora por meio de auxílios à lavoura, que, como vimos, chegaram a equivaler a um quarto do orçamento imperial. Ao comentar tais auxílios concedidos pelo Império, Rui Barbosa chegou a dizer que "nunca se poderia ter inventado cousa mais inútil aos verdadeiros interêsses da agricultura do que êsse gênero de auxílios, aliás, onerosíssimos ao tesouro". Em seu relatório, o ministro entendia que tais auxílios eram destinados à “indústria eleitoral".

Como sabemos, esses auxílios apontavam, na verdade, para um outro problema, do qual eram seus frutos podres: a dificuldade do crédito agrícola. Problema este, aliás, cujos principais prejudicados, os fazendeiros, não se preocupavam adequadamente em resolvê-lo, justamente por poder contar com o governo para custeá-los.

Assim, buscando a raiz do problema, Rui Barbosa tinha como um de seus principais anseios a implementação e o alargamento da hipoteca como fonte de garantia ao crédito para produção agrícola.

\subsubsection{O crédito hipotecário: peça-chave no projeto de reforma liberal.}


Dessa forma, Rui Barbosa atribuía ao crédito hipotecário o papel de salvador da República nascente, representando nesse instituto a expurgação de todos os males herdados do Império.

"Entre o trabalhador e o solo, medeia um obstáculo desesperador: a indigência dos capitais de exploração, a míngua de meios para a subsistência durante o primeiro amanho da gleba e a primeira cultura de suas propriedades produtoras. O crédito hipotecário supre-lhe essas necessidades, cuja satisfação, desentranhado-se em renda, lhe compensará com usura os sacrifícios adiantados. Entre o arquiteto, edificador de cidades, entre o higienista, saneador dos grandes centros populosos, e os seus projetos magníficos de beleza, em utilidade, opulência, em confôrto, em saúde e vida para as populações urbanas, interpõe-se uma possibilidade invencível: a escassez de crédito. A hipoteca oferece-lho e recebe, em trôco das somas, que lhe facilita, a garantia dessas mesmas criações, que ela vai levantar, e que serão amanhã a retribuição de sua liberalidade"

Por vezes, Rui Barbosa chegava a atribuir, com a força de sua retórica, características milagrosas ao instituto que buscava implementar no Brasil.

"Transforma os baldios em campos cobertos de meses, a poder dos recursos que oferece ao trabalho, cujos produtos o virão remunerar. Oferece o deserto ao colono, proporcionando-lhe recursos, para o converter em povoado, florescente, cuja indústria contribuirá, mais tarde, para enriquecer o capital que com suas antecipações o gerou.

\footnotetext{
${ }^{68}$ Relatório do Ministro da Fazenda (1891:37).
} 
Transforma, pela desapropriação e pela edificação, as velhas cidades, e improvisa pelos processos modernos cidades novas, mediante simplesmente as transações de hipoteca aperfeiçoada e adaptada à rápida circulação comercial da propriedade imóvel pelos títulos de crédito emitidos como uma espécie de moeda internacional, aceita em todas as praças do mundo" 69 .

Um bom exemplo de como Rui Barbosa via no crédito hipotecário a solução para os mais diversos problemas nacionais é a questão dos burgos agrícolas. A idéia de sua criação surgiu na Câmara de fins do Império, visando ao desenvolvimento da "riqueza agrícola e industrial do país". Eles seriam criados por meio da concessão de terras devolutas a particulares, com a condição de que estes se comprometessem a instalar, às suas custas, lotes coloniais previamente medidos e demarcados. Dentro de certo prazo préestipulado $^{70}$, os concessionários deveriam restituir ao Tesouro parte do dinheiro arrecado com a venda dos lotes aos colonos. Além disso, eles se obrigariam a oferecer algumas benfeitorias básicas aos colonos, tais como escolas e enfermarias.

No entanto, não obtendo apoio expressivo dos políticos imperiais, tal idéia não chegou a ser posta em prática sob o regime monárquico.

No período republicano, quando eleita a nova Câmara, a idéia dos burgos agrícolas voltou à discussão. Apoiada e encabeçada por um dos principais homens do Governo Provisório, o então ministro da Agricultura, Francisco Glicério, a idéia conseguiu vingar e foram aprovados muitos decretos que autorizavam a criação desses burgos.

Não tardou, entretanto, para que a Câmara voltasse atrás, arrependendo-se de tais concessões e passando a criticar com certa veemência a aplicação prática que o Governo Provisório havia dado ao instituto.

Aprovaram-se diversos decretos declarando caducadas as concessões de terras devolutas para criação de burgos agrícolas. Em sua grande maioria, tais decretos

\footnotetext{
${ }^{69}$ Relatório do Ministro da Fazenda (1891:39).

${ }^{70}$ Geralmente fixado entre dois e três anos.
} 
justificavam a caducidade pela falta de cumprimento das obrigações dos concessionários em realizar a colonização da terra concedida.

O problema é que, freqüentemente, embora não cumprissem sua parte no contrato de concessão, os particulares agiam como se das terras donos fossem, por vezes as registrando em seus nomes, isso quando não chegavam a negociá-las.

Assim, ao querer declarar a caducidade dos contratos, o Estado enfrentava diversos obstáculos, dentre os quais terceiros que já haviam adquirido de boa-fé as terras.

Como se pode ver, o processo de colonização por meio de burgos agrícolas custou dinheiro e insegurança jurídica ao Brasil, por meio de garantias relativamente elevadas de juros e cessões absolutamente descuidadas de terras devolutas. Também para essa prática de cessão de terras e garantia de juros aos burgos agrícolas, que se observava nos primeiros anos de República, Rui Barbosa via a solução no crédito hipotecário.

"Estamos vendo afiançarem-se juros, pelo estado, para a criação de burgos agrícolas. O crédito hipotecário pode multiplicá-lo sem essa garantia. Vemos debater-se o problema da imigração, o grande problema nacional, exclusivamente no círculo estreito dos favores oficiais, dos auxílios diretos do Estado. Pois bem; organizai o crédito hipotecário em todas as suas condições de fecundidade e energia, e tereis criado para a solução desse problema o mais poderoso dos instrumentos. Vemos pensar-se em dar às capitais desacreditadas pela insalubridade, pelo anacronismo de suas edificações, pela insuficiência das viações que as servem, uma reputação honrosa ao país e sedutora ao estrangeiro. E não se lembram senão de impetrar o milagre do crédito do Estado. Mas constitui o crédito hipotecário; e ele dará às empresas particulares, à iniciativa individual os meios de transfigurar, aformosear, sanificar as nossas 
cidades. Basta-lhes para isso o direito de desapropriação e o concurso do banco",71.

Foi com essa confiança no desenvolvimento do crédito hipotecário que Rui Barbosa propôs a criação do Banco Hipotecário Nacional. Ele próprio admitia, entretanto, que sua proposta de solução para os problemas brasileiros não era exatamente original. Não escondia que, no fundo, entendia a criação do Banco Hipotecário Nacional como uma decorrência, uma sistematização, uma modernização de todas as tentativas fracassadas do Império. Esse viés conservador da reforma proposta por Rui Barbosa pode ser notado pela manutenção nos seus postos de responsabilidade de muitos dos homens do Império. Não foi à toa que, em artigo publicado no jornal $O$ País, ele disse que "na administração respeitei as posições adquiridas, acolhendo sem desconfianças os servidores do Império".

No entanto, apesar de se notar essa tendência à continuidade, Rui Barbosa em momento algum considerou as tentativas imperiais modelos a serem seguidos. Dentre as diversas tentativas de ampliação da utilização do crédito hipotecário feitas no Império, uma das mais emblemáticas seria a faculdade de emitir títulos hipotecários concedida ao Banco do Brasil pela reforma de 1864. Ao ver criticada sua proposta de criação do Banco Hipotecário Nacional, por já existir a possibilidade de o Banco do Brasil fazer-lhe as vezes, Rui Barbosa defende-se, citando Teixeira Júnior, que dizia:

"A êste respeito me parece que ao Banco do Brasil, assim como ao Banco Predial, nenhuma lesão resultará à adoção do projeto que discutimos; porque se o Banco do Brasil tivesse podido usar da faculdade que lhe foi concedida nos termos da lei de 1864 , se tivesse podido alargar a emissão hipotecária, como se comprometeu a fazer, nós não teríamos a necessidade de aventurar o Estado a tomar compromisso tão importante, como aquêle que se debate no momento" ${ }^{\text {"72 }}$.

\footnotetext{
${ }^{71}$ Relatório do Ministro da Fazenda (1891:40).

${ }^{72}$ Relatório do Ministro da Fazenda (1891:44).
} 
Assim, vemos que, antes de exemplos a serem seguidos, Rui Barbosa via as tentativas frustradas do Império em alargar a emissão hipotecária como "restos mutilados e esparsos de tentativas condenadas à impotência por um defeito incurável de origem”.

E qual seria enfim este defeito de origem constatado por Rui Barbosa? Em verdade, acredito que se poderia dizer que os defeitos de origem eram pelo menos dois. Um primeiro menos relevante, e um segundo que parece ter maior relevância.

O primeiro, de menor relevância, seria a sujeição das instituições financeiras no Brasil às influências político-partidárias. Para resolver esse problema, Rui Barbosa defendia que a administração do banco fosse entregue aos interessados, isto é, aos acionistas, cabendo a eles a eleição de toda a diretoria e da presidência.

A esse respeito, por meio de uma comparação dos bancos nacionais com os estrangeiros, escreve Barbosa:

"Nos bancos nacionais, pelo contrário, a intrusão do elemento pessoal, da camaradagem indígena, da emulação política, dos corrilhos pessoais que ela fomenta, é irresistível. As transações de proteção pululam, inevitáveis. O comércio bancário atrofia-se, desvirtuado, empobrecido, rebaixado pelos particulares, em prejuízo do dinheiro dos acionistas, da dignidade do trabalho, do caráter dos estabelecimentos, da riqueza nacional. Eis os riscos, que me empenhei em fugir, entregando ao capital estrangeiro, e pondo fora de tôda a ação oficial a administração do Banco, mediante a escolha de toda a diretoria, inclusive o seu presidente, pelos interessados"73.

\footnotetext{
${ }^{73}$ Relatório do Ministro da Fazenda (1891:45).
} 
O segundo problema, este, sim, fundamental para a resolução do problema do crédito hipotecário em nosso país, consiste na questão de terras do Brasil.

\subsubsection{A questão de terras na tentativa de reforma de Rui Barbosa}

Já tivemos oportunidade de esboçar a íntima ligação existente entre o crédito hipotecário e a regularização da propriedade imobiliária, especialmente a rural, no Brasil. Com efeito, essa ligação é praticamente imediata, uma vez que títulos que não garantem segurança e certeza da propriedade de terras dificilmente conseguiriam atrair o interesse de prestamistas em tê-los como garantia de seus créditos.

Rui Barbosa não fechou os olhos a essa realidade. E percebeu que, para usar o remédio da hipoteca, que, como vimos, era o que ele julgava adequado a resolver o problema do crédito da produção agrícola no Brasil, não poderia se escusar de enfrentar este outro problema: a regularização da propriedade imóvel.

Chega-se aqui a um ponto fundamental desta pesquisa, no qual se começa a vislumbrar como a instituição do sistema de Registro Torrens pelo Governo Provisório da República, que veremos no capítulo seguinte, não foi apenas uma atitude antecipada, precipitada e pouco refletida, como querem alguns, mas sim parte de um projeto maior de reforma. Vê-se que o Governo Provisório esperava que o Registro Torrens atuasse como uma engrenagem componente de todo um sistema formulado para que alguns dos principais problemas do país fossem sanados.

Ao falar do anseio de Rui Barbosa pela criação e implantação efetiva do crédito hipotecário em nosso país, já se desenharam algumas poucas linhas do que seria o contorno desse projeto de reforma. Aprofundemos esse esboço.

Quem descreve bem o projeto de reforma de Rui Barbosa são os autores Maria Yedda Linhares e Francisco Carlos Teixeira da Silva em seu livro Terra Prometida (1999). Vejamos um pouco dessa descrição.

Para mostrar a tentativa de reformulação realizada pelos reformistas liberais no princípio da República, os autores se valem de uma distinção conceitual realizada por Lênin em seu célebre $O$ Desenvolvimento do Capitalismo na Rússia. Nesse livro, Lênin tece observações teóricas sobre o caráter das formações sociais capitalistas e sobre o 
Estado burguês, afastando a concepção, que se poderia chamar evolucionista, da passagem direta dos modos e formas de produção pré-capitalista ao modo de produção capitalista. Com isso, ele mostra que, na formação social russa do final do século XIX, marcada pelas relações de produção servis em razão da presencia majoritária do campesinato e da grande propriedade fundiária, a transição ao capitalismo no país poderia adotar dois caminhos: a via junker ou a via farmer - mais lento no caso da primeira, por conservar "ainda por muito tempo os traços da servidão", e supostamente mais acelerado no caso da segunda.

É justamente dessa distinção que os autores fazem uso para compreender a tentativa liberal de reforma. A via farmer seria o modelo de desenvolvimento agrário desenvolvido pelos países novos, de fronteiras abertas, em especial pelos Estados Unidos. Como se pode notar pela própria tradução da palavra farmer (algo como agricultor familiar ou pequeno fazendeiro), esse modelo se basearia na pequena propriedade e na capitalização dos produtos agrícolas e dos bens a ele relacionados, inclusive a terra. Em contraposição, a via junker, também denominada e mais conhecida como via prussiana (expressão relativa à Prússia, região alemã dominada por grandes latifundiários, em que prevalecia a agricultura comercial voltada à exportação), se fundamentaria na propriedade latifundiária e no enobrecimento de seu proprietário.

Dessa forma, além das diferentes dimensões das propriedades nos dois modelos de desenvolvimento agrário (pequena propriedade vs. latifúndio), podemos notar outra distinção fundamental. Enquanto no primeiro a terra é considerada apenas mais um bem no processo de produção agrícola, tendo assim um preço a ela equivalente, no segundo ela é considerada um símbolo de status e de poder político, ou seja, quase um título de nobreza, o que dificulta a atribuição de um preço a ela, vez que não é apenas por seu fator econômico que ele se mediria.

Para Linhares e Silva, a concepção de mundo agrário dos liberais reformistas da nascente República era "marcada pela experiência de países novos e de fronteiras abertas, tais como os Estados Unidos, Austrália e Nova Zelândia" (LINHARES e SILVA, 1999:71). Isso porque a existência de amplos e ociosos espaços ainda vazios - fronteiras abertas - fazia com que os liberais de então identificassem as condições agrárias de nosso país com a desses outros. 
Assim, os autores encontram nos Estados Unidos a origem da idéia liberal de fundar o financiamento da produção agrícola no crédito hipotecário. O sistema inspirador dos liberais teria sido aquele instituído e organizado pelo governo americano, em que "inúmeros bancos privados poderiam financiar a atividade agrícola, impulsionando o progresso do país". Ocorre que, como seria de esperar, os empréstimos não seriam concedidos sem que fossem resguardadas garantias para os casos de não pagamento. Dessa forma, os bancos exigiam como garantia a terra de seus devedores e, se não fossem pagos os débitos, os bancos ressarciam-se "dos prejuízos através do leilão das terras dos inadimplentes" (LINHARES e SILVA, 1999:71).

Os autores entendem que, até a Proclamação da República, a via prussiana teria sido aquela historicamente adotada em nosso país. Assim, vêem na proposta de reforma liberal do princípio da República uma grande inovação não só com as condições vigentes na época de sua tentativa mas também quando confrontada com toda a história agrária do país ${ }^{74}$.

Com efeito, a tentativa de implantação da via farmer atentava por diversos flancos contra os interesses dos grandes latifundiários brasileiros.

Primeiramente, ao propor esse modelo de desenvolvimento agrícola, os liberais buscavam atribuir um valor mercantil à terra, ou seja, buscavam incluir a terra definitivamente na esfera de circulação do capital, e seu preço passaria a ser determinado por procedimentos econômicos explícitos, como os mecanismos de renda diferencial da terra, renda de situação, além das benfeitorias realizadas.

Pouco acostumados a respeitar leis, tendo seu padrão de vida marcado pelo mandonismo, os grandes latifundiários não eram atraídos pela idéia de, de uma hora para outra, ter de abandonar seus títulos de nobreza de proprietários de terras e passar a ser meros agentes econômicos, sujeitos às leis econômicas. Sabendo que boa parte de seu poder se fundava no caráter extrajurídico, e mesmo extra-econômico, da terra, considerada como bem 'fora do mercado', ou melhor, 'acima do mercado', os grandes latifundiários

\footnotetext{
74 “Tal proposta representava, em verdade, uma ruptura radical com o passado agrário brasileiro: a rejeição dos interesses fundiários como hegemônicos, a intangibilidade da propriedade fundiária e a subalternização do capital (representado, no caso, pelos bancos)" (LINHARES e SILVA, 1999:71).
} 
entenderam que, nesse ponto, a proposta liberal atentava não só contra seus interesses econômicos, mas contra toda a estrutura em que seu poder se fundava.

Além disso, um outro efeito, que se poderia considerar reflexo desse primeiro, também atentava contra os interesses latifundiários. Com a mercantilização da terra, sendo possível a ela atribuir um valor, tornava-se também viável usá-la, agora enquanto bem com valor, para garantir empréstimos. Como já se viu, o problema do crédito para a produção agrícola atravessou grande parte do Império e, tendo em vista a dificuldade e principalmente a falta de vontade política em encontrar outra solução, o Estado normalmente arcou com os custos do financiamento da produção, muitas vezes por meio dos bancos agrícolas públicos, a juros baixos e sem as garantias adequadas. Com a possibilidade da instituição efetiva do crédito agrícola, os latifundiários viram-se não só na possibilidade de perder seu status de nobreza, como ainda no risco de nem mesmo serem agora considerados agentes de mercado, uma vez que, caso não pagassem suas dívidas, poderiam perder suas terras. Perderiam, ainda, os empréstimos oferecidos pelo Estado, normalmente em condições excessivamente vantajosas.

No entanto, para que o crédito hipotecário realmente fosse implantado, uma outra reforma tornava-se necessária: a regularização das propriedades imobiliárias e dos registros que a confirmavam, especialmente das propriedades rurais. Dessa maneira, surge um terceiro fator que preocupava os interesses latifundiários na reforma liberal de Rui Barbosa. Se houvesse um sistema efetivo de registro e cadastro de terras, tal como o exigia a instituição da hipoteca, os grandes latifundiários não só teriam gravemente dificultada sua costumeira atividade de se apropriar ilegalmente de terras devolutas e de pequenos sitiantes que os circundavam, como ainda corriam risco de perder algumas de suas terras ilegalmente apropriadas.

Um outro efeito da reforma liberal, este em parte decorrente do anterior, ainda atentava contra os interesses da grande propriedade. Com a existência de um cadastro geral de terras e de um registro de terras eficaz, facilitar-se-ia imensamente um outro antigo anseio liberal: a cobrança efetiva de um imposto territorial significativo. A medida liberal vinha justamente na contramão das intenções dos grandes proprietários agroexportadores, que pretendiam não só se manter sem a obrigação de pagar qualquer imposto sobre suas 
propriedades imóveis, como ainda intentavam diminuir o imposto sobre a exportação por eles pago. Mais um motivo, assim, para que a reforma liberal não fosse por eles bem recebida.

Há ainda na reforma um último efeito contrário aos interesses latifundiários, para o qual, por sua complexidade e importância, será reservado o Capítulo 5. Trata-se da íntima ligação entre a regularização da propriedade imobiliária e o histórico embate entre grupos centralizadores e descentralizadores. Com efeito, ao tentar fazer com que a União abarcasse a competência para demarcar e registrar as terras, o Governo Provisório atentou fortemente contra interesses descentralizadores, que percebiam, por todas as razões acima expostas, que a questão de terras era ponto nevrálgico dos debates políticos e econômicos de então. Com isso, o Governo Provisório levantou contra si um inimigo que, com a imensa força que vinha acumulando durante todo o processo de instauração republicana, acabou por minar boa parte de sua reforma. 


\section{Cap. 4 - O Registro Torrens no direito brasileiro.}

\subsection{Introdução.}

No capítulo anterior, buscou-se esboçar a tentativa de reforma liberal projetada por Rui Barbosa. Deu-se especial enfoque à importância atribuída ao ministro da Fazenda à inserção definitiva da terra na esfera de circulação do capital e o conseqüente alargamento do uso do crédito hipotecário como meio de financiamento da produção agrícola.

Viu-se ainda como estão intimamente relacionados o crédito hipotecário e a regularização da propriedade imobiliária. Com isso, nota-se que o sistema de Registro Torrens, forma eleita por Rui Barbosa para tentar regularizar a propriedade imobiliária no país, é um componente fundamental da tentativa de reforma liberal que ele buscou implementar no Brasil.

Neste capítulo, será analisada a conformação jurídica pela qual o Governo Provisório procurou adotar o sistema Torrens de registro imobiliário. Antes disso, no entanto, faremos uma breve incursão histórica pelos sistemas registrais imobiliários brasileiros que o antecederam, para que possamos contrastá-los com o sistema Torrens. passarmos a

\subsection{Breve histórico dos sistemas brasileiros de registro antecedentes.}

Em 1843, surge a primeira lei brasileira que cuida de registro de direito real, a Lei Orçamentária $n^{\circ} 317$, de 21 de outubro, regulamentada pelo decreto $n^{\circ} 482$, de 14 de novembro de 1846, criando o registro geral de hipotecas. A hipoteca, direito real de garantia, vincula o bem gravado, que fica sujeito à solução de débito. Portanto, a lei teve por fim resguardar o crédito, e não o domínio privado. Foi, contudo, a primeira normatização sobre registro de direitos reais sobre imóveis, sendo encarada por alguns como o embrião do sistema brasileiro de registro de propriedade imobiliária (SOUZA, 2007:02).

Em 18 de setembro de 1.850 foi editada a Lei de Terras, a qual instituiu a Repartição Geral de Terras Públicas. A função registral foi, então, delegada à igreja católica, ficando o registro conhecido como registro do vigário ou registro paroquial. $\mathrm{O}$ registro paroquial foi instituído pelo decreto $\mathrm{n}^{\circ} 1.318$, de 30 de janeiro de 1854 , que 
regulamentou a Lei de Terras. Tinha finalidade meramente declaratória, não se operando por meio dele a transferência da propriedade. $\mathrm{O}$ referido registro não partia dos elementos constantes dos livros de registros de sesmarias, ficando na dependência da iniciativa das partes interessadas, para as quais bastava provar a posse das terras declaradas por posses. Ainda que a lei dispusesse ser obrigatório o registro das posses de terras no Registro Paroquial, na prática não houve interesse relevante dos possuidores de terras em efetivar este registro.

Em Nas fronteiras do poder, a autora Márcia Motta levanta algumas possíveis causas dessa resistência dos posseiros em efetivar o registro paroquial. Segundo a autora, para o declarante registrar significaria, de alguma forma, limitar seu poder, ou, então, limitar à extensão de suas terras; talvez por receio de ser contestado por seus vizinhos; ou por entender ser o registro desnecessário, uma vez que independentemente dele sua posse já seria reconhecida por todos. Muitos alegavam ainda dificuldades pela distância, falta de conhecimento da legislação ou falta de recursos, já que o registro deveria ser pago por letra (MOTTA, 1998:166-169).

Em julho de 1864, o conselheiro Nabuco de Araújo, então Ministro da Justiça, apresentou um projeto de lei hipotecária à Câmara dos Deputados, projeto convertido na lei $\mathrm{n}^{\circ} 1.237$, de 24 de setembro de 1864, criando o Registro Geral, considerando a transcrição como modo de transferência do domínio e ordenando a escrituração de todos os direitos reais imobiliários. A Lei $\mathrm{n}^{\circ} 1.237$ foi regulamentada pelos decretos $\mathrm{n}^{\circ} 3.453$ e $\mathrm{n}^{\circ} 3.465$, de 1865, denominando "oficiais do registro geral" os profissionais incumbidos do registro. O Registro Geral pode ser considerado o verdadeiro antecedente do Registro de Imóveis (SOUZA, 2007:03).

Por um lado, a Lei $n^{\circ} 1.237$ foi de grande importância ao estabelecer um avanço na formalização do registro sob a tutela estatal, por outro, entretanto, também por meio dela se operou a segunda grande ruptura na continuidade registral, pois os elementos do registro paroquial não serviriam de base para o novo registro público. Além disso, o sistema registrário não era completo. Estavam excluídas do registro, por exemplo, as transmissões causa mortis e os atos judiciais. 
Seguiu-se a Lei n ${ }^{\circ} 3.272$, de 05 de novembro de 1.885, obrigando a inscrição de todas as hipotecas legais. Evidencia-se, mais uma vez, uma maior preocupação com a defesa do crédito do que com o registro da propriedade de imóveis.

\subsection{Características gerais do sistema Torrens de registro.}

Conhecido pelo nome de seu criador, o irlandês Sir Robert Richard Torrens, o Registro Torrens foi criado na Austrália em meados do séc. XIX, sendo convertido em lei em 27 de janeiro de 1858 e mais profundamente prescrito por uma lei de agosto de 1861 . Sua principal finalidade foi organizar os títulos de domínio, de transferência e aquisição de propriedades. Para tanto, o Registro Torrens fez da matrícula do imóvel uma prova bastante segura do direito de propriedade, dando à inscrição caráter constitutivo, e não meramente declaratório, como o era no registro paroquial. Reforçava-se, assim, a fépública e restringiam-se os casos de ação contra terceiros adquirentes.

O Registro Torrens resulta de um contencioso especial, dependendo, portanto, de intervenção judicial. Assim sendo, precederá ao assento do imóvel um processo preliminar, de caráter judiciário, onde haverá prévia discussão dos títulos exibidos ao oficial, abrindo-se prazo, dentro do qual aqueles títulos poderão ser impugnados, em contestação ao pedido. Caso não haja contestação ou caso seja esta repelida, efetua-se o registro em favor de quem se prolatou a decisão. Desta forma, fundamentando-se em sentença transitada em julgamento, o Registro Torrens confere a quem o efetuar um direito praticamente incontestável, tornando-o portador de um título de matrícula que o protege de impugnações anteriores; por haver presunção juris et de jure de certeza de que não poderá ser atingido por qualquer ação, salvo raras exceções descritas mais adiante.

Também veremos, nos itens seguintes, mais detalhadamente as principais características do Registro Torrens. Por ora, vale dizer que uma de suas marcas é seu afastamento do sistema francês de registro imobiliário e sua aproximação do sistema alemão, ao estabelecer o sistema da publicidade real, e não pessoal. Isto quer dizer que no sistema Torrens o livro de registro se organiza mais em função do imóvel (publicidade real) do que em função do proprietário (publicidade pessoal).

Além disso, é essencial deste sistema a unicidade de título imobiliário, no sentido de que um imóvel deve estar registrado tão-somente em uma matrícula, pois, caso 
haja multiplicidade de matrículas, em algum momento ocorreu um vício que deve ser sanado pela anulação das matrículas sobressalentes.

Por fim, uma última característica a ser destacada do sistema Torrens é a instituição de um fundo de garantia, gerado pelas taxas pagas na efetivação do registro, com o objetivo de garantir que eventuais indenizações por irregularidades não sejam arcadas pelo titular do registro, mas sim pelo Estado. Com isso, aumenta sobremaneira a segurança gozada pelo proprietário que se valeu desse sistema de registro.

\subsection{Instituição do Registro Torrens no Brasil.}

Menos de quatro meses após da promulgação do decreto $\mathrm{n}^{\circ}$ 169-A, que fez algumas sutis alterações na lei hipotecária de 1864, o Governo Provisório publica o decreto n ${ }^{\circ}$ 451-B, de 31 de maio de 1890, que estabelecia "o registro e a transmissão de imóveis pelo sistema Torrens".

Acompanhado de uma explicativa Exposição de Motivos redigida por Rui Barbosa, pode-se claramente notar a inserção da adoção do sistema dentro de um projeto mais amplo de reforma. O então ministro da Fazenda deixa bastante claros seus objetivos com a instituição do sistema, os quais, para ele, se resumiriam em três princípios cardeais:

" 1 . Instituição de um processo expurgativo, destinado a precisar a propriedade, a delimitá-la, e fixar de modo irrevogável, para com todos, os direitos do proprietário, autenticando-os em um título público;

$2^{\circ}$. Criação de um sistema de publicidade hipotecária, adequado a patentear exatamente a condição jurídica do solo, com os direitos reais e gravames que o onerarem;

$3^{\circ}$. Mobilização da propriedade territorial mediante um conjunto de alvitres, convergentes a assegurar a transmissão pronta dos imóveis, a constituição fácil das hipotecas e a cessão delas por via de endosso" ${ }^{\text {"75. }}$.

\footnotetext{
${ }^{75}$ Exposição de Motivos (1890:01).
} 
Vê-se, assim, num breve exame, como se encontravam ligados os problemas do crédito hipotecário, da mobilização e da regularização da propriedade imobiliária. E, mais do que isso, como Rui Barbosa via o início da solução de todos esses problemas num único instituto: o Registro Torrens.

Vejamos um pouco mais detalhadamente como o decreto $\mathrm{n}^{\circ}$ 451-B conformava a aplicação desse instituto no Brasil, analisando também o ato normativo que regulamentou essa lei, o decreto $n^{\circ}$ 995-A, de 5 de novembro de 1890.

\subsection{Caráter absoluto e expurgatório do Registro Torrens.}

Sem sombra de dúvidas, a maior de todas as vantagens prometidas pelo sistema Torrens é o caráter absoluto de que o título reveste a propriedade matriculada. A segurança que se espera obter por meio desse sistema não pode ser comparada àquela oferecida por nenhum outro sistema de registro. Uma vez matriculado o imóvel, a propriedade consolidase de maneira definitiva na pessoa do requerente. É nesse sentido que a lei diz que "nenhuma ação de reivindicação será recebível contra o proprietário de imóvel matriculado" (art. 75 do dec. 451-B e art. 128 do dec. 995-A).

Nesse sentido, uma vez matriculado o imóvel, poder-se-ia dizer que ele estaria garantido por um título indestrutível. Com a segurança daí proveniente, Rui Barbosa acreditava que a mobilização da propriedade imóvel estaria incentivada, não havendo mais motivos para que o capital receasse investir-se em terras. Além disso, por se fundar em títulos fortes, ou melhor, indestrutíveis, a propriedade imobiliária se valorizaria.

"A indestrutibilidade do título constitui, manifestamente, um dos caracteres inestimáveis do regímen australiano. $\mathrm{Na}$ incerteza sôbre o direito da propriedade territorial está uma das influências que profundamente a depreciam e um dos embaraços que organicâmente se opõem à sua mobilização. A segurança estribada nesse título de domínio irrevogável habilita o proprietário a não recuar ante os maiores 
sacrifícios para a exploração da terra, e atrai para ela as ambições do capital, livre por êsse meio dos riscos que ordinariamente o detêm ante a perspectiva de litígios embaraçosos e arruinadores, como os que flagelam a propriedade imóvel. Nos têrmos da legislação comum, a firmeza da propriedade pende indefinidamente das questões armadas pela malevolência, pelo despeito, pela cobiça, carecendo sempre de um processo dispendioso, para se defender, toda vez que a opugna. No regímen Torrens desaparece radicalmente a possibilidade eventual da contestação, afirmando-se de uma vez para sempre o direito por uma declaração especifica e irretratável da autoridade do Estado" $" 76$.

Diz-se que o título do Registro Torrens tem a característica de expurgatório, no sentido de que ele limpa, corrige, justifica a propriedade sob ele matriculada de toda imperfeição ou irregularidade anterior. Rui Barbosa acreditava que um dos graves defeitos de nosso sistema de registro é ser ele baseado em uma cadeia de relação de títulos, sendo que cada título baseia-se na validade do título que o antecede, tornando todo o sistema tão frágil quanto fosse o mais frágil dos elos da cadeia. Esse problema, para ele, estaria sanado pela adoção do sistema Torrens.

"Julgado êsse direito, por sentença do magistrado competente, efetua-se a inscrição sob o nome daquele em favor de quem se pronunciou o julgado. A êste se entrega o título. E daí em diante esta fechada a questão sôbre o direito do possuidor. Contra êle não se podem intentar reclamações ou demandas; e as que surgirem serão sustentadas pela Fazenda (ou, na hipótese da concessão atual, pela

\footnotetext{
${ }^{76}$ Exposição de Motivos (1890:03).
} 
companhia), que responde à ação, e, vencida, indeniza os prejudicados.

No regime usual, o direito de propriedade e sua conseqüência, a reivindicação, não se destroem, nem modificam pela publicidade dada a uma alienação, a uma constituição de hipoteca, se o proprietário aparente não fôr o proprietário real. A propriedade subsiste, com a sua conseqüência, o direito de reivindicação, em todo e qualquer caso", 77 .

\subsection{Exceções ao caráter absoluto do título Torrens.}

Ao contrário dos outros sistemas de registro, o sistema Torrens tem como regra amplamente geral o caráter absoluto de seu título. Entretanto, existem três exceções abertas pelo decreto $n^{0} 451-A$, em que não vale o princípio de que, depois de matriculada a propriedade, ela se torna absoluta e indisputável.

Tais exceções são tratadas nos arts. 70 a 76 do citado decreto e regulamentadas pelos arts. 119 a 122 e 127 a 129 do decreto $\mathrm{n}^{\mathrm{o}}$ 955-A. Trata-se de hipóteses bastante restritas. Consistem essas exceções na realização de matrícula (i) fraudulenta ${ }^{78}$, (ii) com erro de limites e (iii) feita posteriormente e relativamente ao mesmo imóvel. Os dois primeiros casos referem-se à própria operação de matrícula, de maneira que se confere à vítima do erro ou da fraude uma ação de reivindicação para corrigir a irregularidade. No último caso, visto que o primeiro título registrado no sistema Torrens é também ele considerado indestrutível, e por anteceder este ao outro título, não haveria razão para preferir o mais recente, de maneira que cabe proprietário registrado na primeira matrícula uma ação anulatória para declarar inválida a segunda matrícula.

\footnotetext{
${ }^{77}$ Exposição de Motivos (1890:05).

78 Apenas a título de observação, alguns exemplos de registro fraudulento no sistema Torrens seriam (i) registro requerido com fundamento em títulos falsos; (ii) matrícula requerida por um condômino, que se diz senhor de todo o imóvel, em detrimento dos demais condôminos; (iii) venda de parte do imóvel e requerimento da matrícula dele todo; etc. (BORGES, 1960:31).
} 
Não cabe na presente pesquisa uma reflexão mais longa a respeito dessas hipóteses que excetuam o caráter absoluto do título Torrens. Apenas cabe dizer que, visto como um sistema dentro do qual um dos principais fundamentos é esse caráter absoluto, tais exceções assumem relevância extremamente diminuta, de forma alguma podendo vir a ser tratadas como regra.

\subsection{Fundo de Garantia e responsabilidade do Estado em casos de erro.}

Há, entretanto, casos em que, apesar de não estarem presentes as hipóteses em que se excetua o caráter absoluto do título de propriedade, não se pode negar que houve erro e que alguém que efetivamente teria direito à propriedade do imóvel viu-se dele alijado.

Não descuidou o sistema de trazer remédio a esses casos, buscando conciliar a segurança incontrastável do título em que se baseia todo o sistema Torrens com a satisfação daqueles prejudicados pelo erro de registro.

A solução encontrada foi a criação de um Fundo de Garantia que buscava juntar dinheiro para que, nos casos de erro, o sistema pudesse corrigir suas falhas sem ruir e evitando ao máximo avançar sobre o erário. Assim, antes de ser feita a matrícula de um imóvel, o requerente devia pagar à União uma taxa, equivalente a dois por mil $(0,2 \%)$ do valor da propriedade. Denominada taxa de seguro ou Fundo de Garantia, essa taxa representava uma compensação à União para que ela assumisse e garantisse a propriedade contra qualquer litígio.

Portanto, a União se responsabiliza pela defesa da propriedade em juízo e, caso vencida, pela indenização do prejudicado pelo erro. Note-se, dessa forma, que, mesmo que se prove em juízo que foi cometido erro e que a propriedade deveria pertencer a outra pessoa, a propriedade registrada pelo Torrens não se vê abalada, e ao prejudicado apenas cabe o direito de se ver indenizado pelo erro pela União.

No sistema, o Estado afiança a certeza jurídica da propriedade que ele próprio confere por meio do título. O dinheiro recolhido a título de taxa de seguro serve como contrapartida a essa fiança. Não poderia, dessa forma, a União alegar não estar obrigada a indenizar tal prejudicado com direito reconhecido por se terem esgotados os recursos do 
fundo de garantia do sistema, uma vez que a própria União, com seu patrimônio, afiançava a certeza do título.

Não é por outra razão que, na Exposição de Motivos da lei, Rui Barbosa tem uma preocupação bastante grande em demonstrar como, na experiência internacional, os recursos arrecadados superam os valores pagos em indenizações, buscando tranqüilizar aqueles que receassem que tal afiançamento colocasse em perigo o Tesouro público ${ }^{79}$.

\subsection{A unicidade do título Torrens.}

Como se pode antever pelo que já foi dito, há uma outra característica importante do sistema Torrens de registro: a unicidade do título. Nesse sistema, cada propriedade pode e deve estar representada tão-somente por um único título. Isso a fim de evitar que a validade desse título, que se pretende indestrutível e incontrastável, fique dependendo da validade de relações que formassem elos de cadeias, como ocorre no sistema francês.

“A prodigiosa facilidade e a segurança incomparável dêste mecanismo assentam, pois, na unicidade do título.Êsse método evita as acumulações de instrumentos de domínio, representando cada propriedade, ou fração dela, em um só documento, no qual o proprietário matriculado possuirá, para as transações em que entrar, o quadro completo da situação jurídica do imóvel" 80 .

\footnotetext{
79 "Nem se suponha que essa responsabilidade aventure o Tesouro a riscos superiores ao valor do seguro arrecadado. A experiência mostra o contrário. Em 152.000 títulos conferidos no espaço de muitos anos pelo registro das colônias não se conhece quase caso de erro (Torrens, Transfer of Land, pág. 20). De 1872 a 1881 a estatística registrada por Fortescue (Registration of title to Land, págs. 74 e 75) é a seguinte:

Austrália Meridional: em 22 anos de lei Torrens, aparece um indenização de £ 80 (Fundo: $£$ 40.000).

Queensland: em 18 anos e meio, uma indenização de £ 1.500 (Fundo: £ 11.000).

Tasmânia: nenhuma indenização em mais de 18 anos (Fundo: £ 3.600).

Vitória: em 18 anos de registro, £ 924 desembolsadas pelo Estado em indenizações (Fundo: £ 38.000).

Nova-Gales Meridional: quase 18 anos. Nenhuma indenização (Fundo: £ 38.000). Registram-se títulos cuja origem remonta a 1795 .

Nova-Zelândia: quase 10 anos. Nenhuma indenização (Fundo: £ 25.500).

Austrália Ocidental. Cinco anos. Indenização, nenhuma.

Total: três indenizações pagas, no valor de £ 2.504, em um fundo de garantia de £ 180.000”.

${ }^{80}$ Exposição de Motivos (1890:06).
} 
Assim, todos os títulos do requerente da matrícula Torrens são substituídos por um único título. Julgado procedente o pedido de matrícula por sentença com trânsito em

julgado, é feita a matrícula do imóvel. Esta consiste no lançamento, em livro próprio, da descrição do imóvel. Há nesse livro uma parte destacável, que deve conter a reprodução exata daquilo que foi descrito e consignado sobre o imóvel no livro Matriz. O lançamento ou registro é, dessa maneira, feito em duplicata, sendo entregue ao proprietário a parte destacável, que constituirá, daí por diante, o título de domínio, substituindo todos os anteriores.

Lembrando que um dos principais objetivos buscados na adoção do sistema é a mobilização da propriedade imóvel, no caso de alienação do imóvel matriculado, basta que o proprietário preencha formulários impressos ou, na falta destes, redija um escrito de transferência, o qual deve ser assinado pelo alienante, pelo adquirente e por duas testemunhas. O oficial do registro então anula o título apresentado com o escrito de transferência, no todo ou em parte, caso seja a venda total ou parcial, e entrega um novo título ao adquirente, sem nenhum vínculo com o título anterior, já anulado. Assim, o título proveniente da transferência da propriedade tem validade própria, emanado diretamente do Estado para o proprietário, sendo totalmente ignorada a situação em que a propriedade se encontrava antes dessa emanação, pois, com a emissão do novo título, a antiga propriedade já exauriu todo e qualquer efeito que poderia ter.

\subsection{O registro da hipoteca e de outros direitos reais.}

Esse sistema da unicidade do título também ampara os direitos reais que gravarem o imóvel, em especial a hipoteca. Assim, apresentado o escrito de hipoteca, o oficial do registro fará a respectiva anotação na folha-matrícula do imóvel e também no seu título.

Como já se viu, um dos principais objetivos da Lei Torrens foi o alargamento e a difusão do crédito hipotecário. Nesse ponto, o sistema Torrens foi muito bem escolhido, por facilitar enormemente esse tipo de garantia. A hipoteca é consignada no próprio livro Matriz, na folha correspondente ao imóvel onerado. Alguém que queira consultar a 
situação do imóvel encontrará ali a hipoteca que sobre ele pende. Além disso, ela também se registra no título que fica com o proprietário.

Ao descrever as vantagens do sistema no que tange à hipoteca, Rui Barbosa afirma que o próprio título consubstancia "o quadro dos compromissos" que gravam a propriedade imobiliária. Nesse ponto, Rui Barbosa usa, em sua Exposição de Motivos, o exemplo do Registrar-General da Colúmbia Inglesa, que, ao se referir ao sistema Torrens, em 1889, dizia: “celebram-se hipotecas com a mesma rapidez com que na Inglaterra se transferem ações de banco; bastando uma busca de cinco a dez minutos, para se averiguar perfeitamente a situação de qualquer título registrado".

O sistema teria ainda a vantagem adicional de evitar as fraudes. Isso ocorreria, segundo Rui Barbosa, com base na identidade entre o título que porta o proprietário e o registro feito no livro Matriz. Para ele, com o novo sistema de registro, a fé pública deixaria de ser "um predicado individual do funcionário público, para se tornar uma resultante material do registro".

\subsection{O penhor imobiliário para empréstimos de curto prazo.}

Uma outra facilidade prometida pelo sistema Torrens referia-se a empréstimos de curto prazo. O sistema possibilitaria ao proprietário oferecer seu imóvel em penhor de uma dívida de curto prazo. Para tanto, bastaria que o proprietário entregasse ao credor pignoratício, sendo que a simples tradição obstaria a alienação e a hipoteca do respectivo imóvel, enquanto o título se encontrasse com o credor (art. 82 do dec. 955-A) ${ }^{81}$.

É nesse sentido que Rui Barbosa diz que:

“(...) o talão (que é o título ou certificado do registro), entregue ao proprietário, transferível por endôsso, caucionável por simples depósito, confere ao senhor da propriedade o meio de transferi-la rapidamente como um título comercial" ${ }^{\prime 2}$.

\footnotetext{
${ }^{81}$ Decreto n ${ }^{\text {0 } 955-A: ~ “ A r t . ~ 82 . ~ O ~ t i ́ t u l o ~ d e ~ p r o p r i e d a d e, ~ e m ~ r e l a c ̧ a ̃ o ~ a o s ~ i m o ́ v e i s ~ s u j e i t o s ~ a ~ e ̂ s t e ~ r e g i ́ m e n, ~ e ́ ~}$ suscetível de penhor. Êste constitui-se simplesmente pela tradição do dito título ao credor pignoratício, obstando ela, enquanto durar, a alienação do imóvel respectivo".

${ }^{82}$ Exposição de Motivos (1890:07).
} 


\subsection{Publicidade real, e não pessoal.}

Há uma classificação bastante usual no estudo dos sistemas de registros públicos, dividindo-os entre aqueles que adotam a publicidade real e os que elegem a publicidade pessoal. Na primeira categoria, o livro de registro se organiza mais em função do imóvel. Na segunda, mais em função do proprietário.

Utilizado no modelo francês de registro público, o sistema da publicidade pessoal consiste na organização dos livros e índices em função pessoal, isto é, pelos nomes das partes, de modo que, na prática, a indagação sobre a situação de um imóvel exigiria a pesquisa pelo nome da cadeia dos proprietários, o que causaria uma série de inconvenientes ao sistema de publicidade.

Já no sistema Torrens de registro, da mesma forma que nos sistemas germânicos de registro, a publicidade é real, e não pessoal. Com publicidade real se quer dizer que, no livro de registro, organizado com base nos imóveis, e não nos proprietários, basta examinar a folha do livro relativa ao imóvel pesquisado para verificar sua situação, pois ali estão registradas todas as mutações pelas quais o imóvel passou.

No sistema Torrens, especificamente, existe um livro chamado Matriz, em que cada propriedade é descrita, com suas características, confrontações, área, benfeitorias existentes e encargos que vinculam o imóvel. Assim, um determinado imóvel, em sua folha do livro Matriz, seria descrito não apenas fisicamente, mas também juridicamente.

O título Torrens pretende, dessa forma, identificar em sua descrição a exata situação da propriedade registrada. Não é por outra razão que a Lei Torrens prevê que, antes de ser matriculado ou inscrito, o imóvel passe por um rigoroso levantamento topográfico realizado por técnico habilitado, além de uma rigorosa apreciação dos títulos de domínio por parte da autoridade judiciária.

\subsection{Caráter facultativo para as propriedades privadas.}

Antes de falar no caráter facultativo do Registro Torrens para as propriedades privadas, faz-se necessário ressaltar uma importante distinção. Quando da promulgação do decreto que instituiu o sistema Torrens de registro, havia terras que antes pertenciam ao 
Estado e, desde a promulgação da Lei de Terras de 1850 e a conseqüente confirmação da existência da propriedade privada no Brasil, estavam no domínio privado. Dessa forma, tais terras não eram mais consideradas terras públicas. A facultatividade de adesão ao sistema Torrens de registro se referia unicamente a essas propriedades, ou seja, àquelas que já haviam saído do domínio público e passado às mãos particulares. Dessa forma, pode-se notar que, quanto às terras devolutas, como veremos adiante, o decreto previa a obrigatoriedade, e não a facultatividade do Registro Torrens.

Dito isso, vejamos então o caráter facultativo para as propriedades privadas. $\mathrm{O}$ art. $1^{\circ}$ do decreto $\mathrm{n}^{\mathrm{o}} 451-\mathrm{B}$ estipula que todo imóvel pode ser inscrito sob o regime daquele decreto, ou seja, ficou bem clara a faculdade atribuída ao proprietário de requerer ou não o Registro Torrens de sua propriedade.

Com efeito, o sistema australiano de registro, fonte confessa de inspiração do decreto, tinha como uma de suas principais características a facultatividade de adesão ao sistema de registro. Na Exposição de Motivos do decreto, inclusive, o legislador entende que essa facultatividade é parte inerente do sistema de registro.

"Tem por característico essencial êsse regímen o ser facultativo. Pode o proprietário da terra elegê-lo, ou deixarse ficar sob a legislação comum" ${ }^{\prime 3}$.

\subsection{Obrigatoriedade do Registro Torrens nas terras devolutas e na} capital federal.

No Brasil, entretanto, curiosa exceção se fez notar quanto à facultatividade de registro das propriedades privadas no sistema Torrens. Trata-se da possibilidade, aberta pelos art. $1^{\circ}$ do decreto $\mathrm{n}^{\circ} 451-\mathrm{B}$ e art. $2^{\circ}$ do regulamento $\mathrm{n}^{\circ}$ 955-A, de o governo sujeitar os imóveis da capital federal à obrigatoriedade do Registro Torrens. $\mathrm{O}$ decreto não fixou a obrigatoriedade do registro para esses imóveis, mas permitiu ao governo que, caso julgasse conveniente, instituísse tal obrigatoriedade.

\footnotetext{
${ }^{83}$ Exposição de Motivos (1890:09).
} 
"Art. $1^{\circ}$. (...) Serão também obrigatoriamente sujeitos ao mesmo regímen, se o Govêrno julgar conveniente, os terrenos e prédios da Capital Federal no perímetro marcado para o impôsto predial".

Essa possibilidade de obrigatoriedade da sujeição das propriedades privadas ao Registro Torrens é inovação do legislador brasileiro, não encontrando nenhum paralelo com a experiência internacional de aplicação do registro.

Fazendo uso da faculdade que the foi concedida, o Governo Provisório instituiu, pelo decreto $\mathrm{n}^{\circ} 1155-\mathrm{A}$, de 10 de dezembro de 1890 , a obrigatoriedade do registro para os imóveis circunscritos na capital federal ${ }^{84}$. Além dessa disposição, o decreto ainda

${ }^{84}$ Decreto $^{\mathrm{o}} 1155-\mathrm{A}$, de 10 de dezembro de 1890 :

"O Marechal Manoel Deodoro da Fonseca, Chefe do Governo Provisório da República dos Estados Unidos do Brazil, constituído pelo Exército e Armada, em nome da Nação, attendendo ao que requerem Domingos Theodoro de Azevedo Júnior, o Barão de Paranapiacaba e o Barão de Souza Lima, e usando da faculdade concedida no Decreto n. 955-A, de 5 de novembro último, art. 2, última parte, concede-lhes autorização para organizarem, nesta Capital, uma sociedade anonyma, sob a denominação de Registro Torrens Urbano, com o capital de 2.000:000\$, dividido em 10.000 acções de 200\$, a qual durará 30 annos e tomará a si o registro de todos os terrenos e prédios da Capital Federal, dentro do perímetro do imposto predial, comprehendidos os que de novo se edificarem;

Obrigando-se os concessionários a:

$1^{\circ}$. Estabelecer e organizar, à sua custa e em edifício próprio, o serviço do registro, com todo o material necessário ao bom desempenho deste, passando o mesmo edifício ao Estado, findo o prazo de duração da sociedade.

O pessoal do registro compor-se-há:

a) do official do registro, que será um dos directores da sociedade, sob a fiscalização do juiz competente, gozando para todos os actos em que, na forma do Decreto $n^{\circ} 451-\mathrm{B}$, de 31 de maio último, deva esse funcionário figurar de fé pública e dos outros privilégios do cargo;

b) de um ajudante e dos escripturários e empregados que o serviço exigir, respondendo a sociedade civilmente pelos actos de todos estes prepostos.

$2^{\circ}$. Encarregar-se gratuitamente do processo do registro, até a matrícula, inclusive, correndo à conta dos interessados a despeza de imprensa, de que trata o art. $8^{\circ}$, e do processo de oposição, descrito no capítulo $3^{\circ}$ do Decreto $\mathrm{n}^{\circ} 451-\mathrm{B}$, de 31 de maio deste anno, sendo os actos para processo dos títulos, até final sentença, escriptos pelo escrivão do juízo.

$3^{\circ}$. Entregar ao proprietário do immóvel o título do registro, que torna irrefragável o seu direito dominical e o respectivo extracto, quando requerido; ficando responsável pelas indemnizações, perdas, dnnos e custas que de erro ou fraude do official do registro provierem ao referido proprietário.

O Governo por sua parte se obriga:

$1^{\circ}$. A ceder à sociedade o direito de arrecadar as taxas, constantes da tabella annexa ao Decreto $\mathrm{n}^{\circ} 451-\mathrm{B}$, de 31 de maio deste anno, para consecução dos fins delle; fazendo-se directamente a cobrança dessas taxas, sob a avaliação, na forma do art. 23 , par. $1^{\circ}$, conforme a citada tabella, e concedendo-lhe os privilégios das dívidas fiscais; 
fazia a concessão do serviço de registro dos imóveis da capital a Domingos Theodoro de Azevedo Júnior, ao Barão de Paranapiacaba e ao Barão de Souza Lima, concessão esta com prazo de duração previsto de trinta anos. Para tanto, os concessionários deveriam organizar uma sociedade anônima, denominada Registro Torrens Urbano, para a qual seria transferida a concessão do serviço, o que efetivamente se realizou com o decreto $\mathrm{n}^{\mathrm{o}} 1232$ $\mathrm{B}^{85}$, de 30 de dezembro de 1890 .

O decreto $\mathrm{n}^{\mathrm{o}}$ 1155-A ainda trazia uma série de obrigações a que se sujeitavam os concessionários, de um lado, e o governo, de outro. Dentre as obrigações do governo, estavam (i) a cessão à sociedade do direito de arrecadar as taxas, constantes da tabela anexa ao decreto $\mathrm{n}^{\mathrm{o}}$ 451-B; (ii) a efetivação da obrigatoriedade do registro de todos os prédios e terrenos da capital federal; e (iii) o revestimento do oficial de registro de fé pública e dos privilégios do cargo de escrivão das hipotecas. Quanto às obrigações dos concessionários, elas restringiam-se ao estabelecimento dos serviços de registro, por sua conta e risco.

Conforme registra Borges (BORGES, 1960: 43), esse decreto provocou uma intensa reação de diversos setores da sociedade fluminense, em especial da imprensa e dos tabeliães da cidade do Rio de Janeiro. Os tabeliães representaram contra o mencionado decreto, dando a essa representação forte publicidade. Mais tarde, Rui Barbosa se defenderia dizendo que, antes de visar ao bem público, a reação contrária ao decreto deviase ao medo de perda de privilégios e de "receita dos cartórios".

A repercussão foi tamanha que, em fevereiro de 1891, um discurso proferido por Vinhaes na Assembléia Constituinte apontava o caráter contraditório da decisão de Rui

$2^{\circ}$. A tornar obrigatório o registro de todos os prédios e terrenos da Capital Federal, dentro do perímetro do imposto predial, e obrigando cada immóvel que for transmittido, a qualquer título, a pagar a taxa do augmento do valor, que haja porventura tido;

$3^{\circ}$. A revestir de fé pública e dos privilégios do cargo de escrivão das hypothecas o director que servir de official de registro, e seu ajudante, conferindo aos demais empregados da repartição, creada para o registro, o caracter de funccionários públicos

Todas as vezes que o immóvel passar a outro proprietário, tomar-se-há por base, para a cobrança da taxa, o valor que se the acrescer, porventura, depois do registro e vice-versa".

${ }^{85}$ Decreto $^{\circ} 1232-\mathrm{B}$, de 30 de dezembro de 1890 :

"O Marechal Manoel Deodoro da Fonseca, Chefe do Governo Provisório da República dos Estados Unidos do Brazil, constituído pelo Exército e Armada, em nome da Nação, attendendo ao que requerem Domingos Theodoro de Azevedo Júnior, o Barão de Paranapiacaba e o Barão de Souza Lima, resolve conceder-lhes permisão, afim de transferirem à Companhia Brazileira Torrens a concessão que obtiveram pelo Decreto $\mathrm{n}$. 1.155-A, de 10 de dezembro de 1890, para organizarem a sociedade anonyma sob a denominação 'Registro Torrens Urbano"”. 
Barbosa em estabelecer a obrigatoriedade do Registro Torrens na cidade do Rio de Janeiro, onde o sistema cadastral se encontrava em estágio mais avançado, e não fazê-lo nas propriedades rurais, onde a falta de registro mais falta fazia. Tal contrariedade, para Vinhaes, se justificava pelos interesses envolvidos:

"Neste paiz, que acaba de sair do regimen da escravidão e da monarchia e onde existe grande parte do território completamente oculto, não se estableceu a lei Torrens para as propriedades ruraes, visto a isso se oporem os grandes senhores feudaes, vindo-se estabelecel-á exactamente na parte do Brazil onde o cadastro é uma realidade" (Diário do Congresso Nacional, 5 de fevereiro de 1891, pg. 367).

Note-se, entretanto, que, ao contrário do que a análise isolada desse trecho do discurso proferido pode levar a pensar, não era pela obrigatoriedade geral do registro Torrens que se levantava Vinhaes, mas, sim, pela generalização de sua facultatividade:

“A fome já principia a sentir-se entre as classes pobres desta capital.

Ao que se deve isto, pergunta o orador?

Não quer especificar, mas é forçado a declarar que ao Sr. Exministro da fazenda se deve em grande parte semelhantes estado de cousas.

Não contente em ter sido o principal motor da elevação do preço dos gêneros de primeira necessidade, contribuindo em grande parte para isso o imposto em ouro, ainda estableceu nesta capital a célebre lei Torrens obrigatória, tornando-a excepção odiosa, inconcebível, não se compadecendo com o regimen que se diz democrata. 
Em que parte do mundo, pergunta o orador, existe a lei Torrens obrigatória?

Em nenhuma absolutamente.

A lei Torrens provou muito bem na Austrália, como disse muito bem o ex-ministro da fazenda, porque ali foi facultativa.

$\mathrm{Na}$ Inglaterra se tem também tentado a mesma lei em diversos condados sem se ter conseguido até hoje leval-á a effeito, o que vem provar mais uma vez a efficácia da política experimental: o que é bom para a Austrália pode trazer conseqüências lamentáveis para a Inglaterra e viceversa" (Diário do Congresso Nacional, 5 de fevereiro de 1891, pg. 367).

Ainda se pode extrair do discurso de Vinhaes uma forte acusação a Rui Barbosa. Vinhaes insinua que a obrigatoriedade do Registro Torrens Urbano se deveria à intenção do ex-ministro de favorecer a sociedade concessionária do serviço.

"Não contente o Sr. Senador pela Bahia em estabelecer semelhante lei especial, ainda a entrega ao monopólio odioso de uma companhia, que indirectamente vae explorar as classes pobres que são as únicas a soffrer nos seus effeitos perniciosos.

\section{$(\ldots)$}

É levado a crer que a intenção do Sr. ex-ministro da fazenda organisando a lei Torrens nesta Capital foi unicamente (é triste dizel-o) para dar monopólio a uma companhia 
protegida, monopólio odioso e indigno de uma democracia que se presa" (Diário do Congresso Nacional, 5 de fevereiro de 1891,pg. 367).

Tamanha foi a repercussão do decreto e da resistência contra ele que, em 1891, Rui Barbosa foi levado a prestar informações a seu respeito ao chefe do Governo Provisório, informações essas que se transformaram no trabalho A Execução da Lei Torrens na Capital Federal.

Nesse texto, Rui Barbosa pretende mostrar como, em verdade, a reação dos tabeliães não se restringia apenas à concessão feita pelo decreto $\mathrm{n}^{\mathrm{o}} 1155-\mathrm{A}$, mas se dirigia a toda a instituição do Registro Torrens, uma vez que, na visão de Barbosa, esse sistema "libertou das formalidades onerosas e inúteis da escritura pública os atos de transmissão do domínio e constituição dos ônus reais”.

Nesse relatório, Rui Barbosa procurou sustentar que a obrigatoriedade do Registro Torrens na capital federal não desvirtuava o sistema Torrens de registro. Para tanto, argumenta ele que o caráter facultativo dado à Lei Torrens por seu autor foi uma contingência determinada pelas circunstâncias da época, pois se tratava de uma inovação, uma experiência que entrava em choque com o espírito conservador do inglês, averso a essa revolução no regime de terras. Nota-se aqui que Rui Barbosa contradiz o que ele próprio havia afirmado na Exposição de Motivos do decreto $\mathrm{n}^{\circ}$ 451-B, quando dizia que o sistema Torrens tinha "por característico essencial (...) o ser facultativo".

Continuando sua defesa, Rui Barbosa afirma que a lei australiana, como a brasileira, também determinava que as terras devolutas alienadas pela Coroa a partir de sua publicação seriam obrigatoriamente registradas no sistema Torrens. Alegando que a enorme maioria das terras australianas eram ainda 'terras devolutas', no sentido de ainda pertencerem à Coroa, a exceção da obrigatoriedade assumia na verdade preponderância de regra.

Ainda argumentando contra o notariado fluminense, Rui Barbosa afirma que o sistema não foi planejado para defender os interesses deste: 
"Sir Robert Torrens não planejou e formulou o seu registro para o acomodar aos moldes e tradições do notariado, aos estilos forenses, às complicadas fórmulas judiciais. Pelo contrário, um dos fitos esseciais na sua concepção era, desde o comêço, emancipar o proprietário dos embaraços do fôro, habilitá-lo a dispensar o notário e o advogado. (...) Daí a guerra, que, por tôda a parte, notários e homens de fôro moveram sempre à inauguração dêste regime, e que, entre nós, já tardava" (págs. 33 e 34).

Vê-se que um dos pontos principais em que Rui Barbosa se apegava na sua defesa é a simplicidade do sistema Torrens frente aos onerosos e complexos procedimentos com os quais a tradição registral brasileira estava não só acostumada como interessada. Assim, Rui Barbosa buscou ressaltar o caráter administrativo do processo de registro no sistema Torrens, contrapondo-o ao processo judicial:

"O serviço do registro de propriedade, pois, neste regímen, despiu as fórmulas lentas e embaraçosas do antigo direito, afastou-se das exigências forenses, e revestiu, na quase totalidade das suas funções, um caráter propriamente administrativo.

A missão judicial do funcionário que preside o registro finda no momento de declarar-se matriculável a propriedade em nome do indivíduo que lhe requer a inscrição.

Tudo o mais são fórmulas de escrituração puramente materiais, subordinadas a regras tão simples, quão seguras, que estreitam a ação dos agentes de registro num mecanismo 
quase automático, onde não se deixa o menor interstício à invasão do arbítrio, ou a insinuação da fraude.

Daí a natureza administrativa das repartições, a que, no continente australiano, se confia a execução do registro Torrens. Não são tribunais, não são cartórios, não são ofícios de justiça; são ramos da administração pública, sob a presidência de um funcionário alheio à magistratura judicial, incumbido apenas das atribuições precisas para apreciar a legalidade dos títulos de domínio, e ordenar-lhes o registro".

Com efeito, como bem atentado por BORGES (1960: 46), ao se estudar a lei Torrens, nota-se em sua terminologia uma constante e minuciosa preocupação de Rui Barbosa em evitar atribuir ao pedido de matrícula características que o incluíssem na categoria de ação judicial. Assim, a lei dá o nome de requerimento ao que se poderia chamar de petição inicial (art. $5^{\circ}$ do dec. 451-B e art. 26 do dec. 955-A). Nela, os confrontantes e demais interessados são notificados, e não citados. As notificações, ou intimações, são arquivadas em separado, e não juntadas ao processo (art. $9^{\circ}$ do dec. 451-B e art. 34 do dec. 955-A). Além disso, chama-se de oposição a contestação oferecida ao registro (art. $46^{\circ}$ do dec. $451-\mathrm{B}$ e art. 90 do dec. 955-A), a qual deve ser deduzida por embargos (art. 93 do dec. 955-A).

Entretanto, ao contrário do que afirma BORGES, isso não parece se tratar de uma mera "vacilação" injustificada de Rui Barbosa em conferir caráter de ação ao procedimento do Registro Torrens. Em vez disso, parece ser clara sua intenção de marcar o sistema Torrens como um divisor de águas entre a complexidade do processo judicial e a simplicidade do processo administrativo.

O próprio Rui Barbosa, no entanto, distinguirá mais adiante em seu trabalho duas fases no procedimento do Registro Torrens ${ }^{86}$. Uma primeira, preliminar, de caráter

\footnotetext{
86 “Precede à inscrição um processo preliminar, de caráter judiciário, em que, à luz da publicidade mais ampla e mais severa, se abre a todos os interessados a discussão sôbre o direito do possuidor, que promove a matrícula, em relação à propriedade a que ela se refere". (Barbosa, Ruy. A execução da lei Torrens na Capital Federal, Obras Completas, vol. XVIII, 1891, tomo IV, pág. 63)
} 
judiciário e contencioso, em que se abre a todos a discussão sobre o direito do possuidor. Essa discussão seria rematada por decisão judicial, não sujeita a recurso, concedendo ou denegando a matrícula. A segunda fase, constitutiva do processo administrativo do registro, partiria do trânsito em julgado da decisão concessiva da matrícula. Assim, todas as alienações posteriores à matrícula seriam atos caracteristicamente administrativos, ficando apenas o oficial do registro sujeito à fiscalização do juiz competente.

Por fim, ao se defender das acusações de tentativa de favorecimento da empresa concessionária do Registro Torrens Urbano, Rui Barbosa alega que não haveria nenhum prejuízo ao interesse público, uma vez que, com a concessão, a função de registro estaria "estritamente subordinada à fiscalização da mesma magistratura" que fiscalizaria os oficiais do registro de hipotecas se a tarefa a eles fosse confiada ${ }^{87}$. Realmente, o decreto $\mathrm{n}^{\mathrm{o}}$ 1155-A previa essa fiscalização.

\footnotetext{
87 "Simplificado assim, reduzido à singeleza de uma combinação administrativa, das mais rudimentares, o serviço do registro podia, sem o mínimo inconveniente, confiar-se a uma êmpresa particular, desde que essa êmpresa, no exercício das funções inerentes a esta missão, ficasse estritamente subordinada à fiscalização da mesma magistratura, que, na hipótese de cometer-se a tarefa aos oficiais do registro de hipotecas, devia superintender ao processo de matrícula Torrens" (Barbosa, Ruy. A execução da lei Torrens na Capital Federal, Obras Completas, vol. XVIII, 1891, tomo IV, pág. 51)
} 


\section{Cap. 5 - A reforma econômica de Rui Barbosa.}

\subsection{Introdução.}

No Capítulo 2, já foi possível analisar alguns dos principais precedentes econômicos do governo imperial, sobretudo no que se referiu às crises financeiras e comerciais da segunda metade do séc. XIX, às políticas econômicas restritivas e às correlatas dificuldades do crédito agrícola e da escassez de meio circulante.

Neste capítulo, se procurará descrever a tentativa de reforma econômica levada a cabo pelo então ministro da Fazenda Rui Barbosa. Com isso, tem-se um duplo objetivo. Primeiramente, se pretende demonstrar como Rui Barbosa buscou tratar, na seara econômica, os problemas da escassez do meio circulante e do crédito agrícola, os quais, como se vê no Capítulo 3, eram considerados intimamente ligados à propriedade imobiliária e ao registro e à demarcação de terras. Além disso, há uma segunda motivação que justifica este capítulo. Deixando-se de lado os efeitos nefastos que a crise do Encilhamento viria a exercer mais tarde sobre o país, trabalha-se aqui com a hipótese de que, quando contrastada com as políticas econômicas restritivas da segunda metade do Império, a política econômica de Rui Barbosa, com a forte ativação das atividades econômicas e a larga folga creditícia por ela gerada, pode ter funcionado, no curto prazo e de forma paliativa, como fator de amenização das dificuldades do crédito agrícola. Com isso, questiona-se se, ao possibilitar temporariamente crédito fácil, a reforma econômica não teria, como efeito perverso, esmorecido os interesses que, em outro cenário, se voltariam ao crédito hipotecário e, conseqüentemente, desviado as atenções da regularização, da demarcação e do registro de terras.

\subsection{As dificuldades iniciais do Governo Provisório.}

Mal raiava a República e, já na tarde do próprio 15 de novembro, diretores dos principais bancos do Rio de Janeiro se reuniram com o Marechal Deodoro para lhe pedir que preservasse suas caixas de qualquer violência. Além dessa demonstração de

insegurança dos bancos nacionais, a queda vertiginosa experimentada pelos títulos da dívida brasileira no exterior levou o Governo Provisório, logo na publicação de seu primeiro documento oficial, a preocupar-se em manter a estabilidade, declarando que "o Governo Provisório reconhece e acata os compromissos nacionais contraídos durante o 
regime anterior, os tratados com as potências estrangeiras, a dívida pública externa e interna, contratos vigentes e mais obrigações legalmente estatuídas”.

Entretanto, tal declaração não foi suficiente para apaziguar os ânimos estrangeiros, sendo necessário que o novo ministro da Fazenda, Rui Barbosa, enviasse à Europa o então já Conde de Figueiredo para que, como afirmou o ministro em telegrama dirigido ao Barão de Itajubá, este transmitisse "noções mais exatas e seguras, acerca da situação econômica (...) dissipando idéias absurdas e restabelecendo a antiga confiança, naturalmente um pouco abalada agora, na estabilidade dos bens do nosso crédito".

Com efeito, durante seus primeiros dias, o Governo Provisório deu continuidade às medidas do Gabinete Ouro Preto, credenciando novos bancos emissores e adiantando as prestações previstas pelos contratos de auxílio à lavoura. No entanto, a insegurança gerada pela revolução fez com que se tornasse "uma necessidade inelutável da conservação republicana", nas palavras de Rui Barbosa, a interferência governamental na tentativa de estabilizar a taxa cambial (BARBOSA, 1892:32) $)^{88}$.

Para entender a importância atribuída pelo novo regime às dificuldades enfrentadas pelo mercado monetário, é interessante a afirmação que mais tarde faria Rui Barbosa de que "a situação do nosso mercado monetário foi a primeira e mais imperiosa das questões, que se me impuseram logo nos primeiros dias da revolução" ${ }^{\prime 9}$.

\subsection{A crise do Banco Nacional.}

Apesar de todo esse empenho governamental, em fins de novembro, uma recusa de saque do Banque de Paris et des Pays Bas, parceiro internacional do Banco Nacional, estremeceu a confiança na estabilidade do câmbio, pois dava a entender que o poderoso parceiro parisiense do Banco Nacional eximia-se do esquema de sustentação do câmbio, e, sem esse apoio, o Banco Nacional seria incapaz de intervir decisivamente no mercado de câmbio. Frente a essa situação, o Banco Nacional solicitou ao ministro da Fazenda a suspensão da conversibilidade de suas notas, fazendo uso da supracitada cláusula do contrato de 02 de outubro (item 2.7.2.), alegando que a situação se encaixava na previsão de "revolução, crise política e financeira".

\footnotetext{
${ }^{88}$ No mesmo texto, um pouco mais adiante, diria Rui Barbosa que, "no dia imediato a uma comoção como essa, em face da revolução, em presença do desconhecido, a temperatura natural do câmbio é naturalmente de zero. O governo seria imbecil, se não prevenisse esse resfriamento, se não opusesse a essa rigidez iminente os recursos mais heróicos".

${ }^{89}$ Relatório do ministro da Fazenda (1891:52).
} 
O caráter conflituoso da relação entre o ministro da Fazenda e o Conde de Figueiredo pode ser notado pela resoluta recusa do pedido, alegando o ministro que fora pessoalmente contrário ao contrato, como o comprovava sua atuação na imprensa, acrescentando ainda que, "no meio do assombro causado pela nossa revolução nas praças estrangeiras, a decretação do curso forçado repercutiria além do oceano, como confissão formal do descrédito do governo" ${ }^{90}$.

Assim, frente ao estremecimento da relação entre governo e Banco Nacional, o encargo de controle cambial recairia novamente sobre o Tesouro, que, não dispondo de instrumentos para executá-lo, voltou a procurar para tanto o Banco do Brasil. Essa medida anódina não seria suficiente, entretanto, para encobrir as fraquezas do esquema de sustentação do câmbio montado pelo Visconde de Ouro Preto, do qual dependia todo o regime monetário do governo anterior. Tal fragilidade era tão patente que, no início de dezembro, o presidente do Banco do Brasil, Conselheiro Manuel Pinto de Souza Dantas, escreveu ao ministro da Fazenda, dizendo que, dada a situação, "a sustentação do câmbio a 27 dinheiros neste momento não parece ser medida muito prudente, e suas conseqüências podem ser desastrosas".

Durante o mês de dezembro, a taxa de câmbio experimentou uma contínua baixa, o que acabou por ocasionar uma corrida contra o Banco Nacional, a qual foi analisada pelo ministro da Fazenda como "uma retração de numerário relativamente diminuta, mas [que] encheu de dificuldades e temores a praça" ${ }^{91}$.

O Governo Provisório pouco fez para tentar salvar o sistema econômico montado pelo governo anterior, não faltando quem visse nisso certa dose de cálculo político. Nesse sentido, FRANCO insinua:

"Parecia, por um lado, haver uma certa dose de cálculo na atuação do Ministro, que, não se empenhando, ou não conseguindo sustentar a taxa de câmbio, se tornava responsável pela corrida contra o Banco Nacional, cuja conseqüência óbvia era a destruição do sistema de bancos emissores de bilhetes conversíveis" (1987:98).

\footnotetext{
${ }^{90}$ Relatório do ministro da Fazenda (1891:130).

${ }^{91}$ Relatório do ministro da Fazenda (1891:8).
} 
Tal desinteresse em socorrer o sistema anterior ficaria ainda mais evidente com a publicação, em 27 de dezembro, de um decreto que fixava em três meses o prazo máximo para que os bancos completassem seus limites autorizados de emissão, sob pena de essa autorização caducar. Apesar da justificativa oficial do decreto ser a tentativa de forçar emissões para atenuar as dificuldades do mercado monetário, na verdade, ao obrigar os bancos a emitir bilhetes conversíveis a 27 pence por mil réis, quando a taxa cambial era próxima de 24 pence por mil réis, o ministro selava a falência do sistema de Ouro Preto, de bancos emissores de bilhetes conversíveis.

Alguns dias depois, em 31 de dezembro, Rui Barbosa publicava em todos os jornais um panfleto no qual demonstrava sua intenção de imprimir acentuadas mudanças de rumos na política econômica, já no princípio do ano que se iniciaria.

Parece ser interessante a transcrição de um trecho desse artigo para que se tenha uma idéia da situação econômica na visão de Rui Barbosa antes das reformas de 1890:

“A praça atravessa, neste momento, uma crise. Mas esse fato pertence ainda ao espólio da monarquia. Sob a influência do gabinete que a perdeu, convertera-se aqui o mercado financeiro, há alguns meses, em uma praça de tavolagem, onde se celebram à luz do dia as especulações mais insensatas sobre todas as espécies de valores da Bolsa. Os títulos mais duvidosos, mais vãos, mais inconsistentes, mais fantásticos, acharam crédito, aplauso, avidez. As ações de bancos e companhias de todo gênero ascendiam ao triplo, ao quádruplo, ao quíntuplo da sua importância real. Os hábitos da nossa corretagem, as facilidades do sistema de comprar e vender a longos prazos, a confiança indiscreta em uma política de teatralidades aparatosas favoreceram esse movimento, que se superagitou até ao delírio. Não importava a natureza do título, a situação do vendedor, ou do comprador, a seriedade do intermediário: as ofertas mais desatinadas achavam a mais ampla e cega procura. A liquidação dessas transações devia ser 
inevitavelmente lastimosa e destruidora. A diferença entre a importância efetiva dos valores permutados e o seu preço convencional havia de resolver-se forçosamente nas mãos de alguns dos seus negociadores sucessivos, em prejuízos, cujo alcance devia corresponder às vantagens apuradas pelos especuladores mais hábeis no jogo e mais apressados no ajuste de suas contas" (Diário de Notícias de 31 de dezembro de 1889).

\subsection{As reformas de janeiro de 1890 .}

Com efeito, duas semanas depois, em 17 de janeiro, o ministro da Fazenda lançaria, por meio de um pacote de decretos, as bases de sua profunda e radical reforma econômica. Três foram os decretos publicados no dia 17 de janeiro. Tratava-se dos decretos (i) $\mathrm{n}^{\circ} 164$, que dispunha novas normas sobre as sociedades anônimas; (ii) $\mathrm{n}^{\circ} 165$, que instituía a reforma bancária; (iii) n ${ }^{\circ} 165-\mathrm{A}$, que estabelecia as novas normas sobre crédito móvel em benefício da lavoura; e (iv) $\mathrm{n}^{\mathrm{o}}$ 169-A, de 19 de janeiro, que estabelecia a reforma hipotecária. Como se pode ver, cada um dos decretos consistia na reforma de um setor que, de alguma forma, influenciava toda a política econômica.

$\mathrm{O}$ decreto $\mathrm{n}^{\circ} 165$, que instituía a reforma bancária, seria uma das mais importantes leis de toda a passagem de Rui Barbosa pelo Ministério da Fazenda. Tal lei havia sido proposta em grande parte pelo banqueiro Francisco de Paula Mayrink, que, além de ser presidente e acionista majoritário do Banco Predial, do Banco do Construtor e do Banco Popular do Rio de Janeiro, possuía diversos outros empreendimentos, como indústrias têxteis, agrícolas, companhias de transporte e de colonização ${ }^{92}$. Pode-se dizer que, durante o ministério de Rui Barbosa, Mayrink representaria papel bastante semelhante àquele desempenhado pelo Conde de Figueiredo nos anos do Gabinete Ouro Preto, funcionando como consultor financeiro e um dos principais beneficiários da política econômica implementada no período ${ }^{93}$.

\footnotetext{
${ }^{92}$ A respeito da vida de Mayrink, ver a biografia de Mayrink Lessa (1975).

${ }^{93}$ Para exemplificar, há um relato no diário de Joaquim Nabuco, datado de 28 de fevereiro de 1891, sobre a relação de Mayrink e Rui Barbosa, no qual ele se questiona: "Viste a subscrição Alto Mearim para um Liceu Português no Rio? 1.000 contos ou (1\%) 100.000 contos só da roda Mayrink. Está assim provado o uso feito das emissões". (apud NASSIF, Luis. Rui Barbosa e os ecos do passado, publicado em 19/11/2005 na Folha de São Paulo).
} 
Embora se possam notar algumas inegáveis semelhanças entre o decreto $\mathrm{n}^{\mathrm{o}} 165$ e a lei de novembro de 1888, havia uma diferença fundamental, qual seja, o decreto de 1890 consistia na consagração da inconversibilidade ${ }^{94}$ por meio da liberalização da política de emissão, a qual passaria, então, a se basear essencialmente em títulos de dívida pública. O decreto previa a constituição de bancos emissores de bilhetes lastreados em títulos da Dívida Pública. De acordo com seu art. 4을 os bancos emissores se obrigariam a "converter em espécies metálicas, à vontade do portador e à vista, tão-somente as notas que emitissem um ano depois de o câmbio atingir e manter a taxa de par de 27, ou mais, tomando igual compromisso quanto às notas do governo que houvesse em circulação, sem direito a indenização alguma", o que, de fato, significava, para os contemporâneos do decreto, o estabelecimento do curso forçado, pois poucos acreditavam que tal taxa cambial fosse possível de ser mantida durante um ano ou mais. Na própria exposição de motivos da lei, o ministro da Fazenda dizia que "em um país onde o equilíbrio do câmbio seja estável (...) a emissão sobre metal [seria] a solução racional e legítima, eficaz e criadora", dando a entender que, como o Brasil estava longe de ser um país de equilíbrio cambial estável, havia-se optado pela inconversibilidade.

Com efeito, como mais tarde explicaria em seu famoso discurso ao Senado de 03 de novembro de 1891, intitulado "O papel e a baixa do câmbio", Rui Barbosa entendia que, ao contrário do que queriam os metalistas, não seria o câmbio elevado que levaria a nação à prosperidade, mas, isto sim, que a conversibilidade seria um efeito natural da 'prosperidade da nação':

\section{"não é (...) a circulação metálica que nos há de firmar o câmbio alto; é, pelo contrário, a estabilidade do câmbio ao par, efeito da prosperidade da nação, que nos há de permitir a circulação conversível. Os metalistas invertem os termos do problema e, por}

\footnotetext{
${ }^{94} \mathrm{Cf}$. "A reforma bancária de Rui Barbosa constituía, nas condições de então, uma consagração de fato da inconversibilidade e, nesse sentido, diferia fundamentalmente da lei de 1888. Nesta, tentara-se imprimir no próprio texto da lei mecanismo deflacionista, através do sistema de resgate do papel-moeda do Tesouro, destinado a induzir ou preparar terreno para a circulação metálica conversível, ao passo que na lei de Rui Barbosa não havia intenção de promover, em futuro próximo ou distante, qualquer esforço deflacionista. Nota-se assim, de 1888 para 1890, uma inequívoca evolução da legislação no sentido da inconversibilidade, que se devia ao reconhecimento não só do fracasso das tentativas de estabilização cambial, como também do fato de que os custos sociais envolvidos em uma deflação de grandes proporções pareciam excessivos" (FRANCO, 1987:102).
} 
isso, suas criações não passam de castelos de cartas" (BARBOSA, 1892:29)

Tal posição do ministro da Fazenda fundamentava-se, basicamente, no entendimento de que havia uma enorme necessidade de expansão monetária, dada a escassez de meio circulante no país, frente às crescentes demandas por numerário, devidas não só à libertação dos escravos e ao aceleramento da imigração ${ }^{95}$, como também ao espantoso crescimento das atividades comerciais ${ }^{96}$. Assim, parecia-lhe que as "necessidades dos negócios" só poderiam ser satisfeitas por meio de uma expansão monetária de enorme envergadura, que somente poderia ser alcançada pela inconversibilidade, de forma que manter a conversibilidade seria atentar contra a "prosperidade da nação".

Entretanto, a grande dificuldade de Rui Barbosa estava em estabelecer qual era a quantidade de dinheiro exigida pelas "necessidades dos negócios", bem como fixar garantias de que as emissões não ultrapassariam tais necessidades, de forma que muito importantes eram as limitações quantitativas às emissões estabelecidas pelo decreto.

O decreto de 17 de janeiro fixava em 450 mil contos o limite máximo a novas emissões. Tendo em conta que se tratava de valor que não seria lastreado em ouro, os contemporâneos entenderam exagerada a quantia, havendo expressivas pressões para que ela fosse diminuída, como veremos adiante.

Antes disso, cabe observar que o decreto de 1890 regionalizava as emissões, dividindo-as em três regiões: Região Centro (com sede no Rio de Janeiro, compreendendo os seguintes Estados: Rio de Janeiro, São Paulo, Minas Gerais, Espírito Santo, Paraná e Santa Catarina), Região Norte (com sede na Bahia, contando com Bahia, Sergipe, Alagoas, Pernambuco, Paraíba, Rio Grande do Norte, Ceará, Piauí, Maranhão, Amazonas e Pará) e Região Sul (com sede em Porto Alegre, estando nela inclusos o Rio Grande do Sul, Mato Grosso e Goiás). Cada região contaria com apenas um banco, formando, assim, uma espécie de monopólio regional ${ }^{97}$. Os bilhetes de determinada região somente dentro dela

\footnotetext{
${ }^{95}$ Segundo as estimativas feitas pelo ministro da Fazenda, com o pagamento de salários decorrentes da abolição e da imigração, houve uma elevação de $565 \%$ da necessidade de dinheiro na lavoura. Relatório do ministro da Fazenda (1891:149).

${ }^{96}$ Com relação ao crescimento das atividades comerciais, Rui Barbosa dizia que, em pouco mais de ano e meio (de 13 de maio de 1888 a 15 de novembro de 1889), o capital das empresas constituídas no Rio de Janeiro havia aumentado 97,6\%. Relatório do ministro da Fazenda (1891:149).
} 
poderiam circular, de maneira que, dentro de suas regiões, os bancos deteriam larga autonomia.

$\mathrm{Na}$ verdade, mais tarde Rui Barbosa admitiria que a subdivisão em regiões emissoras fora uma exigência dos anseios federalistas, intimamente atrelados à Proclamação da República, sendo inviável, no alvorecer do novo regime, que se estabelecesse um sistema de monoemissão bancária. A esse respeito, disse Rui Barbosa:

"a torrente dos sentimentos federalistas impunha-nos a necessidade de transigir com as necessidades dos Estados. A monoemissão bancária, ao amanhecer da revolução federalista, seria uma provocação a forças contra as quais não havia poder que lutasse" $\left(\right.$ BARBOSA, 1892:36) ${ }^{98}$.

Ainda tratando do decreto de janeiro de 1890, nota-se que nele havia um mecanismo de resgate $^{99}$ que buscava diminuir as despesas com a Dívida Pública interna, tornando gravosa a emissão aos bancos que dela se encarregavam. Como forma de compensação e para que a onerosidade da emissão não fizesse com que o sistema fracassasse, como ocorreu com o regulamento de janeiro de 1889 da lei de 1888, inúmeros benefícios seriam atribuídos aos bancos que se dispusessem a emitir.

\footnotetext{
${ }^{97}$ FRANCO aponta que se trata de um interessante hibridismo entre a liberdade bancária e o monopólio de emissão, uma vez que, embora haja mais de um órgão emissor, dentro de dada região somente a um compete tal encargo (1987:105).

${ }^{98}$ Ainda ao se defender da acusação de ineficiência da subdivisão em regiões emissoras, Rui Barbosa argumentou:

"não se podia fazer a monoemissão nos primeiros dias da República; já porque convinha dar às várias regiões arras dos sentimentos descentralizadores do governo (...) já porque ainda não havia na estabilidade da situação nascente bastante confiança para lançar os fundamentos de uma reorganização bancária definitiva, apoiadas em sólidos pontos da ação central (...). Era preciso termos satisfeito o melindre das justas reivindicações locais, expondo a nação o nosso grande programa federativo" (Barbosa, apud. Tannuri, 1981:57).

${ }^{99}$ Explicando esse mecanismo, FRANCO o descreve da seguinte forma:

“(...) dois outros dispositivos do decreto estabeleciam encargos aos bancos emissores que poderiam mesmo inviabilizá-los. Os bancos deveriam, ao iniciarem duas operações, reduzir em $2 \%$ os juros que receberiam sobre as apólices constituintes do lastro, que desta forma passariam a lhes render $3 \%$ em vez de $5 \%$. Em seguida, reduziriam, de modo análogo, $1 / 2 \%$ dos juros de $3 \%$ anualmente, de modo que ao cabo de seis anos estaria extinto o pagamento de juros sobre os títulos da Dívida Pública que estivessem servindo como lastro. Afora isso, os bancos deveriam comprometer-se a constituir um fundo, através de uma cota inferior a $10 \%$ dos lucros brutos, destinado a resgatar as apólices do lastro. Pretendia-se claramente com esse sistema, que para Rui Barbosa era 'atrevido e original', aliviar o Tesouro dos encargos relativos à Dívida Pública interna" (Franco, 1987:107).
} 
Com efeito, a lei regulamentava as operações bancárias, que seriam as mais amplas possível, abrangendo não só descontos, empréstimos, câmbio, hipotecas e penhor agrícola, mas também adiantamentos sobre meios de produção, empréstimos industriais para construção civil e de estradas de ferro, docas, portos (PRADO, 2003).

A título de compensação aos encargos da emissão, diversos privilégios eram concedidos aos bancos emissores, muitos deles, inclusive, estranhos à esfera financeira. Como exemplo de tais privilégios, tem-se a cessão gratuita de terras devolutas para fixação de colônias ou fundação de estabelecimento industrial. Os bancos emissores passariam ainda a ter preferência nas concorrências públicas com a finalidade de colonização e emigração, bem como nas de exploração de minas. Além disso, os estabelecimentos industriais por eles fundados gozariam de isenção de quaisquer impostos. Trata-se, como se pode ver, de grandes incentivos aos bancos emissores, não faltando quem deles quisesse gozar.

Como não era de espantar, um dia após a publicação do decreto foi indicado Francisco de Paula Mayrink como responsável pela direção do banco emissor da região central, de longe a mais importante das regiões emissoras, respondendo por aproximadamente $4 / 5$ da movimentação bancária do país.

\subsection{Oposições ao sistema criado pelas reformas de 17 de janeiro.}

Fortes oposições surgiram ao sistema criado pelas reformas de 17 de janeiro. Além do caráter polêmico do conteúdo da reforma, a forma como ela foi apresentada também gerou muita discussão, decorrendo dela, inclusive, uma crise ministerial que chegou a abalar a estrutura do Governo Provisório e pela qual podemos entender um pouco de seu funcionamento. Ou, nas próprias palavras de Rui Barbosa, a publicação dos decretos "arrebentou como uma bomba no seio do Governo Provisório".

Quando da formação do Governo Provisório, tendo em vista a dificuldade gerada pelo necessário abandono de diversos mecanismos decisórios do regime monárquico, criouse uma instabilidade que dificultava a tomada de decisões políticas, instabilidade essa que se materializava nas reuniões dos ministros, que se encontravam longe de formar um grupo homogêneo. A preocupação com a superação dessas diversidades a fim de que se mantivesse a unidade desse grupo, unidade da qual dependia o sucesso do novo regime, fez com que se formasse um acordo tácito de que as questões mais importantes ou graves 
seriam discutidas pelo grupo e decididas por maioria de votos. Buscava-se, com isso, além de dar certa coesão às medidas políticas do governo, retirar parte da responsabilidade do seu "chefe supremo", tornando-a uma espécie de responsabilidade coletiva do corpo ministerial (ABRANCHES, 1907:08).

Nesse sentido se pode entender a indignação dos demais ministros com a forma como se deu a publicação dos decretos de 17 de janeiro de 1890. Nas palavras de ABRANCHES, "a não ser o Secretário da Fazenda, nenhum dos outros membros do governo sequer desconfiava da situação (...). Todos foram surpreendidos pela leitura dos jornais do dia 18" (1907:15). Assim, dada a importância da matéria veiculada nos decretos, justifica-se a imensa repercussão de suas publicações, não faltando quem visse na atitude de Rui Barbosa uma tentativa de golpe político.

Três dias após a data da publicação, em uma reunião ministerial em que não estava na pauta a discussão dos decretos, o ministro da Agricultura Demétrio Ribeiro contra eles se levantou. Das atas da reunião consta a acusação de Ribeiro de que a indicação de Mayrink ao banco emissor central tratava-se de uma "preferência" que consistia "verdadeiro privilégio e monopólio". Sustentou ainda que os bancos emissores absorveriam a função estatal, de forma que iriam "administrar o Estado pelo governo". Rui Barbosa defendeu-se afirmando que a indignação contra o decreto partia de "um grupo de prejudicados e despeitados" e, dando a entender que interesses ligados ao Banco Nacional a fomentavam, disse que "como ministro jamais daria o curso forçado". Dada a rispidez do debate entre os ministros, Deodoro encerrou a reunião, justificando "pelo adiantado da hora" (ABRANCHES, 1907:59-69).

Depois de uma tentativa frustrada de conciliação entre os ministros com a intermediação de Benjamin Constant e ainda após um pedido de exoneração de Rui Barbosa negado por Deodoro, que, segundo relato de Barbosa, "a devolveu, com as mais honrosas expressões de confiança, opondo-se terminantemente [à sua] retirada" (BARBOSA, 1982:353), foi convocada para o dia 30 de janeiro uma reunião ministerial com o específico objetivo de debater os decretos e as circunstâncias que os cercaram.

O apoio do Marechal Deodoro parecia pendente para o lado de Rui Barbosa, não só por este gozar de grande prestígio junto a Deodoro, que, inclusive, dada a fragilidade de seu estado de saúde, o nomeou em 31 de dezembro de 1889 para o cargo de "Vice-Chefe do 
Governo Provisório", mas também por uma aversão de Deodoro a Demétrio Ribeiro. Na própria nomeação do ministro da Agricultura, o marechal pretendia indicar Francisco Glicério, mas não o fez só por ele ser paulista, e Campos Salles e Aristides Lobo já representavam o Estado no ministério. Assim, ao lhe ser indicado por Benjamin Constant o nome do gaúcho Demétrio Ribeiro, o marechal teria respondido: "nunca havia ouvido falar desse nome. Conheci ali no Rio Grande do Sul, como propagandistas do clero republicano, Julio de Castilhos, Assis Brasil, Ramiro Barcelos", e, diante da insistência dos correligionários, declarou: “conhecer, eu não conheço. Mas já que os senhores insistem, eu o nomeio. (...) Não farei questão”.

No entanto, se, por um lado, Rui Barbosa contava com o apoio de Deodoro, por outro, havia forte oposição pública à publicação dos decretos, o que tornava a reunião decisiva, tendo os ministros a clara impressão de que "a não se chegar a um acordo aquela noite, seria inevitável a dissolução do Governo Provisório" (ABRANCHES, 1907:22).

A reunião teve início às nove da noite e, logo em seu início, o Marechal Deodoro posicionou-se no sentido de que a lei de 17 de janeiro já era fato consumado, sendo inviável sua revogação e necessária a superação da crise. Chegou a dizer que, caso a divergência continuasse, abandonaria o poder. Após falas de Benjamin Constant e Aristides Lobo buscando contemporizar a situação, toma a palavra Campos Salles, recordando o desrespeito que ocorrera no consenso ministerial e argumentando que não poderia responder solidariamente por decisões das quais não havia participado. Transcorrido algum tempo, toma a palavra o Almirante Wandenkolk, ressaltando a forte reação da opinião pública contrária aos decretos, temendo, inclusive, "um levantamento". Recorda ao Conselho de Ministros que o governo não passa de provisório e sugere que a eficácia do decreto seja adiada, até que sobre ele se manifestasse o Congresso a ser eleito. A isso Rui responde que se trata de medida urgente, que não pode esperar. Aristides Lobo sugere, então, que as emissões sejam limitadas, respondendo-lhe Rui Barbosa que elas estavam limitadas pela própria natureza. No entanto, diante da insistência de Campos Salles de que melhor seria limitá-las em lei, Rui mostra-se disposto a transigir no ponto. Aberto espaço para concessões, Campos Salles propõe uma outra modificação: a criação de uma quarta região bancária, com sede em São Paulo, ressaltando a movimentação bancária da região. Após alguma resistência, Rui Barbosa cede também quanto a isso. 
Passadas três horas de discussão, Rui Barbosa toma a palavra para realizar a defesa da publicação dos decretos sem consultar o Conselho. Principia por reconhecer que, como regra geral, as decisões dos ministros realmente precisavam se submeter ao Conselho. Entretanto, tal regra comporta exceção quando a natureza da medida assim o necessitar e, antes disso, quando o ministro conta com o apoio do chefe do Estado. Procurando mostrar como contava com o apoio de Deodoro, Barbosa pergunta a ele o que havia feito de sua carta de demissão, ao que ele responde que a havia rasgado. Em conseqüência, após afirmar que não tinha mais como ceder alterações aos decretos, Rui Barbosa exige a solidariedade dos demais ministros, sem qualquer incerteza. Constant busca mediar a relação entre Rui Barbosa e Demétrio Ribeiro, mas este se opõe, dizendo que, por ferir a liberdade bancária, o sistema de emissão traria necessariamente a baixa do câmbio. Mas, ao se ver isolado, Ribeiro declara ser inútil discutir o que já está consumado.

Rui Barbosa havia saído vitorioso da reunião do dia 30 de janeiro. No dia seguinte, seria publicada nos jornais uma declaração conjunta do ministério, com a exceção de Demétrio Ribeiro, que pediria sua exoneração do cargo de ministro, sendo, então, substituído por Francisco Glicério. Na declaração constava que “o gabinete, achando-se reunido em conferência de ontem, teve ocasião de examinar amplamente os assuntos, que dependiam de sua consideração, retirando-se de pleno acordo, adotadas medidas, em que convieram todos os membros do governo" (BARBOSA, 1892:360).

No mesmo dia seria ainda publicado um decreto, o decreto $\mathrm{n}^{\circ} 194$, concretizando as concessões de Rui Barbosa a Campos Salles. Assim, foi criada a quarta região bancária, composta por São Paulo e Goiás. E também foi diminuído o limite da emissão total pelos bancos emissores de 450 mil contos do decreto do dia 17 para apenas 200 mil contos, sendo 100 mil para a região central e os outros 100 mil divididos entre as outras três regiões.

A respeito de tais concessões, Rui Barbosa mais tarde afirmaria que elas "não interessava[m] à essência do regime instituído por mim: apenas o modificava acessoriamente" (BARBOSA, 1892:359). Assim, entendia o ministro da Fazenda que as alterações puramente quantitativas não tinham sido capazes de abalar a estrutura do sistema por ele engendrado.

\subsection{A reforma econômica e o crédito hipotecário.}


Um dos principais dispositivos que não haviam se alterado com as cessões de Rui Barbosa seria o mecanismo antes mencionado de resgate que buscava diminuir as despesas com a Dívida Pública interna. Com os recursos obtidos por meio dessa diminuição das despesas com a Dívida Pública interna, o governo pretendia estimular e implementar a utilização das letras hipotecárias, garantindo-lhes os juros em 6\% e facilitando-lhes as condições, até o prazo máximo de 30 anos.

Como descreve FRANCO, "havia, portanto, embutida no decreto de 17 de janeiro, uma nova tentativa de resolver o problema de crédito de longo prazo à lavoura, que tinha, sobre as tentativas anteriores, a vantagem de poder alterar alguns dispositivos legais, como a arcaica legislação hipotecária, cuja reformulação jamais esteve seriamente sob cogitações durante o período imperial" (1987:108).

Com efeito, com as reformas das leis hipotecárias e das sociedades anônimas, o governo buscava tornar equivalentes, do ponto de vista jurídico, o crédito rural hipotecário e o crédito comercial. Ou melhor, nas palavras da Exposição de Motivos do decreto, procurava "estender a jurisdição comercial aos lavradores que firmarem letras". Pretendiase, dessa forma, remover o emaranhado que envolvia a execução de devedores hipotecários insolventes, que repelia os bancos desse tipo de operação.

O próprio ministro da Fazenda, ainda na Exposição de Motivos do decreto, afirmava que o pacote de decretos formava "um todo indivisível", que se "encadeia sistematicamente", buscando uma "vasta reconstrução", dentro da qual estava reservado um importante papel às letras hipotecárias. Nesse sentido, a Exposição prometia que, "garantido (...) por um fundo especial e proveniente do estado, o serviço da letra hipotecária crescerá, no mercado, a estimação desta, abrindo-lhe curso franco".

A política de Rui Barbosa não agradou a importantes grupos econômicos e políticos domésticos ligados a interesses tradicionais, tendo provocado o temor de uma onda inflacionária, que foi agravada com a contínua queda da taxa do câmbio. A tentativa de regionalizar a emissão bancária encontrou muitas dificuldades para sua implementação tanto no plano econômico como no político ${ }^{100}$. Em 31 de janeiro de 1890, por influência de

\footnotetext{
${ }^{100}$ Rui Barbosa ainda se defenderia da acusação de ineficiência da subdivisão em regiões emissoras: "não se podia fazer a monoemissão nos primeiros dias da República; já porque convinha dar às várias regiões arras dos sentimentos descentralizadores do governo (...) já porque ainda não havia na estabilidade da situação nascente bastante confiança para lançar os fundamentos de uma reorganização bancária definitiva, apoiadas em sólidos pontos da ação central (...). Era preciso termos satisfeito o melindre das justas reivindicações locais, expondo a nação o nosso grande programa federativo" (BARBOSA, apud. TANNURI, 1981:57).
} 
Campos Salles, uma nova região bancária e um novo banco emissor foram criados em São Paulo. Em março, o ministro concedeu ao Banco Nacional do Brasil e ao Banco do Brasil o direito de emitir notas inconversíveis até o dobro de 25.000 contos depositados em espécies metálicas no Tesouro. Esse privilégio seria estendido em agosto a vários bancos emissores regionais e ao Banco dos Estados Unidos do Brasil.

Entre 17 de janeiro e de setembro, as emissões cresceram de 205.000 contos para aproximadamente 290.000 , ou seja, experimentaram um crescimento de mais de $40 \%$. A bem da verdade, o processo especulativo já havia surgido no ocaso do Império, mais especificamente durante o Gabinete Ouro Preto, no entanto, as medidas econômicas tomadas pelo Governo Provisório foram fundamentais para torná-lo crônico, conferindo-lhe a magnitude pela qual ficou historicamente conhecido.

Com todo esse excesso de dinheiro em circulação e toda essa especulação, o período em tela conheceu uma acentuada facilidade de crédito, contrastando, nesse ponto, com a realidade econômica das duas últimas décadas do Império, que, como se viu, foram de política econômica bastante restritiva:

"A transição de uma prolongada etapa de crédito excessivamente difícil para outra de extrema facilidade deu lugar a uma febril atividade econômica como jamais se conhecera no país" (FURTADO, 1972:171).

Pode se falar, assim, que o início da República se marcou por uma acentuada folga creditícia:

"Foi característica dos anos iniciais do Regime Republicano a excessiva folga creditícia relacionada à expansão do papel moeda. Com a expansão do crédito e taxas de juros reais mais baixas, havia um incentivo ao consumo e aos investimentos privados. Embora estes últimos tivessem caráter descompressor sobre as pressões da demanda no médio e longo prazo, agiam intensificando-a no curto 
prazo. Assistia-se, então, a um forte aumento no nível de atividade econômica" (BOTELHO JR., 2003:283).

Sequiosos em valer-se do ambiente especulativo, os bancos flexibilizaram suas exigências de garantia para a realização de empréstimos. Dessa maneira, no que tange mais especificamente ao crédito hipotecário, a alta rentabilidade esperada relegava a um segundo plano a confiabilidade e a segurança exigidas do título de propriedade de terra:

"No entanto, as dificuldades existentes na utilização do escravo ou da terra como garantias bancárias podiam bem ser compensadas, aos olhos dos bancos, pela evidência de uma rentabilidade elevada. E na exata medida em que essa rentabilidade dependia de flutuações no preço e do volume da safra de café, é bastante razoável afirmar que a disposição dos bancos de emprestar, vale dizer, a oferta de crédito a curto prazo, comportava-se de modo marcadamente pró-cíclico" (FRANCO, 1987:79).

Com isso, chega-se a um ponto importante. Com as medidas econômicas tomadas pelo Governo Provisório, tendentes a um acentuado aumento do meio circulante, o crédito, tão difícil durante as últimas décadas do Império, passa a ser abundante. Dentre as muitas modalidades de crédito que, de uma hora para a outra, foram vertiginosamente potencializadas, está aquela que mais nos interessa: o crédito hipotecário.

Como vimos, uma das principais motivações para o Governo Provisório buscar regularizar os registros imobiliários e as demarcações de terras era a possibilidade de a terra, inserida definitivamente na esfera de circulação do capital, passar a ser amplamente aceita como garantia de empréstimos, especialmente dos empréstimos agrícolas. Assim, a instituição do sistema Torrens de registro estava circunscrita a uma reforma mais ampla, voltada à valorização da terra como garantia creditícia e ao alargamento da utilização do crédito hipotecário.

Ocorre que, com as reformas econômicas de excessivo aumento do meio circulante, o crédito hipotecário conheceu abrupto crescimento, mesmo que ainda não houvesse sido 
efetivamente implantada a regularização dos títulos imobiliários prometida pelo Registro Torrens. Com a abundância de dinheiro no mercado, os prestamistas não se negaram a emprestá-lo por meio de hipoteca, mesmo sabendo que a garantia, em muitos casos, não era nem das mais seguras, nem das mais desejáveis.

Apenas para que se possa visualizar a dimensão da intensificação de utilização do crédito hipotecário, recorremos ao trabalho de Renato Leite Marcondes e Paulo Rogério Rodrigues Maduro Júnior (2005), intitulado Crédito Hipotecário em São Paulo: Evidências para um núcleo urbano em expansão (1865-1890). Nesse trabalho, fazendo um levantamento de aproximadamente cinco mil hipotecas, os autores dissecam as condições de financiamento hipotecário em São Paulo ao longo das décadas de 60 a 90 do séc. XIX.

Abaixo, reproduzimos um gráfico no qual os autores mostram a evolução temporal do valor total emprestado per capita em São Paulo no período compreendido entre 1865 e 1890. Note-se que o valor total emprestado representado no gráfico está deflacionado em mil-réis de 1865, o que permite que sejam eliminados na sua análise os efeitos inflacionários.

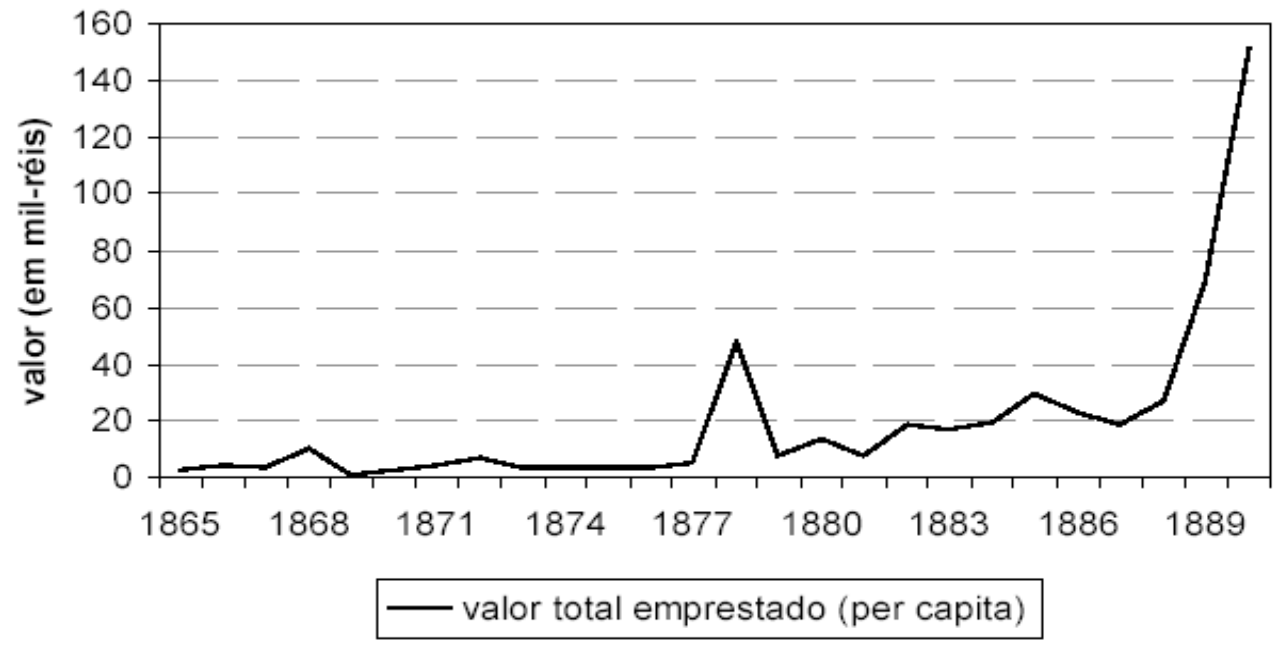

Gráfico 1: Evolução temporal do valor total emprestado per capita (São Paulo, 1865-1890) In.: Crédito Hipotecário em São Paulo: Evidências para um núcleo urbano em expansão (1865-1890) (MARCONDES e MADURO JR., 2005:12).

Vejamos alguns comentários tecidos pelos autores a esse gráfico: 
"[No gráfico] representamos a dinâmica do valor total emprestado deflacionado (em mil-réis de 1865) per capita. A partir deste gráfico, inferimos que o crescimento do mercado superou tanto a inflação quanto o crescimento populacional, de tal sorte que montantes mais elevados foram mobilizados, ou seja, o mercado de crédito foi capaz de propiciar transferências de poupança cada vez maiores entre os agentes. Outra informação importante deste gráfico foi a existência de dois movimentos estruturais que sinalizaram o crescimento do mercado. Primeiramente, percebemos um movimento de crescimento bastante elevado a partir de 1888 , propiciado principalmente pelo crescimento dos meios de pagamento e seus impactos sobre a liquidez da economia" (MARCONDES e MADURO JR., 2005:13).

Inegável que o crescimento da utilização do crédito hipotecário a partir de 1888, mas com uma carregada acentuação a partir de 1889, deve-se em grande parte à política econômica do Governo Provisório.

E o ponto fundamental é que essa acentuação no uso da hipoteca coincide justamente com a época em que se instalou o Congresso Constituinte e em que todo o projeto de reforma do Governo Provisório e de Rui Barbosa seria julgado. Com isso se quer sugerir que não seria descabida a cogitação de que, em razão da folga creditícia ocasionada pela política econômica emissionista, pode não ter sido dada pela Constituinte a devida atenção à discussão do crédito hipotecário e, conseqüentemente, da reforma registral. A conjuntura instavelmente favorável pode ter levado os constituintes a se iludirem, dando tratamento abrandado à necessidade de uma reforma creditícia, conferindo cores suaves ao grave problema do crédito hipotecário e, por fim, colocando a sua frente a resolução de outros problemas, como veremos no capítulo seguinte. 


\section{Cap. 6 - A Constituição de 1891 e a questão de terras.}

\subsection{Introdução.}

Como já dito anteriormente, o movimento republicano não se sustentou em uma base coesa, sendo bastante heterogêneo o perfil de seus apoiadores, de maneira que não seria muito adequado falar em um projeto político republicano para o Brasil, mas, isto sim, em diversos projetos políticos para o Brasil apresentados por diferentes setores defensores da República.

Vimos nos dois capítulos anteriores um desses projetos, o qual ganhou especial importância por ser aquele defendido pelo Governo Provisório. Entretanto, a esse projeto outros se contrapuseram, tornando o período histórico em estudo bastante rico em discussões ideológicas e políticas. Há um momento histórico específico que pode ser encarado como a consolidação da escolha de qual dentre esses projetos políticos seria o adotado pelo país: a promulgação da Constituição de 1891. A bem da verdade, seria melhor dizê-lo, não um momento histórico, mas um processo, o processo da Assembléia Constituinte de 1891.

\subsection{O vácuo constitucional e a "Constituição de bolso" do Governo}

\section{Provisório.}

Antes de falarmos do processo constituinte de 1891, lembremos ainda um pouco mais a atuação do Governo Provisório, agora no que tange à condução desse processo constituinte. Dentre as primeiras medidas adotadas por esse governo, uma das principais foi a promulgação do decreto $n^{\circ} 01$. Essa promulgação deu-se no próprio dia 15 de novembro de 1889, ou seja, no mesmo dia em que o regime monárquico fora derrubado. Sobressai aqui, como em outras medidas que serão vistas adiante, o cuidado do Governo Provisório em conferir um embasamento jurídico ao novo regime que se apresentava. $\mathrm{O}$ decreto $\mathrm{n}^{\mathrm{o}} 01$ de $1889^{101}$ dispunha em seu art. $1^{\circ}$ que a nação brasileira tinha como forma de governo a

\footnotetext{
${ }^{101}$ Parece interessante, por sua relevância, a transcrição do decreto.

"Decreto n. ${ }^{\circ}$ 1, de 15.11.1889: O GOVERNO PROVISÓRIO DA REPÚBLICA DOS ESTADOS UNIDOS DO BRASIL DECRETA:

Art $1^{\circ}$ - Fica proclamada provisoriamente e decretada como a forma de governo da Nação brasileira - a República Federativa.

Art $2^{\circ}$ - As Províncias do Brasil, reunidas pelo laço da Federação, ficam constituindo os Estados Unidos do Brasil.

Art $3^{\circ}$ - Cada um desses Estados, no exercício de sua legítima soberania, decretará oportunamente a sua constituição definitiva, elegendo os seus corpos deliberantes e os seus Governos locais.

Art $4^{\circ}$ - Enquanto, pelos meios regulares, não se proceder à eleição do Congresso Constituinte do Brasil e bem assim à eleição das Legislaturas de cada um dos Estados, será regida a Nação brasileira pelo Governo
} 
"República Federativa". Assim, tanto quanto republicano, o novo regime nasce federativo. Com efeito, esse decreto, de autoria de Rui Barbosa, ao mesmo tempo em que estabelece a forma de governo republicana, instaura o sistema federativo. $\mathrm{O}$ art. $2^{\mathrm{o}}$ do decreto, por exemplo, ao dispor que as ex-províncias passariam a integrar os Estados Unidos do Brasil, instaura, desde logo, o sistema federativo, deixando, inclusive, transparecer a forte influência do constitucionalismo norte-americano, influência essa que se faria presente durante todo o processo constituinte.

A esses artigos seguem outros que buscavam configurar, provisoriamente, como se daria o funcionamento da República Federativa, sendo conferida "legítima soberania" a cada um dos Estados, aos quais cumpriria aprovar oportunamente a sua própria Constituição definitiva, elegendo os seus corpos deliberantes e os seus governos locais (art. $3^{\circ}{ }^{\circ}$. No entanto, o decreto não permitia o reconhecimento de nenhum governo local contrário à forma republicana estabelecida (art. . $^{\circ}$ ). Enquanto não fossem eleitos por meios regulares o Congresso Constituinte e as legislaturas de cada um dos Estados, o decreto determinava que a nação ficaria sob a regência do Governo Provisório da República (art.

Provisório da República; e os novos Estados pelos Governos que hajam proclamado ou, na falta destes, por Governadores delegados do Governo Provisório.

Art $5^{\circ}$ - Os Governos dos Estados federados adotarão com urgência todas as providências necessárias para a manutenção da ordem e da segurança pública, defesa e garantia da liberdade e dos direitos dos cidadãos quer nacionais quer estrangeiros.

Art $6^{\circ}$ - Em qualquer dos Estados, onde a ordem pública for perturbada e onde faltem ao Governo local meios eficazes para reprimir as desordens e assegurar a paz e tranqüilidade públicas, efetuará o Governo Provisório a intervenção necessária para, com o apoio da força pública, assegurar o livre exercício dos direitos dos cidadãos e a livre ação das autoridades constituídas.

Art $7^{\circ}$ - Sendo a República Federativa brasileira a forma de governo proclamada, o Governo Provisório não reconhece nem reconhecerá nenhum Governo local contrário à forma republicana, aguardando, como lhe cumpre, o pronunciamento definitivo do voto da Nação, livremente expressado pelo sufrágio popular.

Art $8^{\circ}$ - A força pública regular, representada pelas três armas do Exército e pela Armada nacional, de que existam guarnições ou contingentes nas diversas Províncias, continuará subordinada e exclusivamente dependente de Governo Provisório da República, podendo os Governos locais, pelos meios ao seu alcance, decretar a organização de uma guarda cívica destinada ao policiamento do território de cada um dos novos Estados.

Art $9^{\circ}$ - Ficam igualmente subordinadas ao Governo Provisório da República todas as repartições civis e militares até aqui subordinadas ao Governo central da Nação brasileira.

Art 10 - O território do Município Neutro fica provisoriamente sob a administração imediata do Governo Provisório da República e a Cidade do Rio de Janeiro constituída, também, provisoriamente, sede do Poder federal.

Art 11 - Ficam encarregados da execução deste Decreto, na parte que a cada um pertença, os Secretários de Estado das diversas repartições ou Ministérios do atual Governo Provisório.

Marechal Manuel Deodoro da Fonseca (Chefe do Governo Provisório), S. Lôbo, Rui Barbosa, Q. Bocaiúva, Benjamin Constant, WandenkoIk Correia. Diário Oficial da República Federativa Brasileira, 16-11-1889 Ano XVIII - No 315 ". 
$4^{\circ}{ }^{\circ}$ ), fixando a composição dos ministérios ${ }^{102}$, além da liderança do governo pelo Marechal Deodoro da Fonseca.

Cinco dias após o decreto inaugural do regime republicano, um outro decreto do Governo Provisório, o decreto $\mathrm{n}^{\mathrm{o}}$ 07, cuidava do funcionamento dos governos estaduais, extinguindo as Assembléias Provinciais e fixando os poderes dos governadores. Assim como o Governo Provisório, também os governadores poderiam exercer, temporariamente, as funções executiva e legislativa. Com isso, o governo central buscava preservar a Federação recém-instituída, protegendo-a de um dos principais riscos a que estava sujeita: a ruína de sua unidade.

Tal preocupação pode ser examinada ainda em outro ato do Governo Provisório, o decreto $\mathrm{n}^{\circ}$ 10, de 23 de novembro de 1889. Embora por esse decreto fosse dada aos Estados autonomia em diversas e importantes matérias, tais como tributação e desapropriação, essa mesma autonomia não era dada quanto ao estabelecimento da força pública estadual, cuja organização ficaria a cargo do poder central. Além disso, o referido decreto diminuía em diversos aspectos a competência de atuação dos governos estaduais, brindando o governo central com a nomeação de importantes cargos da administração estadual, incluindo-se aqui a nomeação dos governadores provisórios.

Ao disporem acerca do funcionamento do sistema federativo, as medidas acima esboçadas, juntamente com algumas outras, que tratavam de outros aspectos do regime instituído ${ }^{103}$, formavam um conjunto que fez as vezes de uma espécie de ordenamento jurídico provisório, ou, na pitoresca expressão de Paulo Bonavides, uma "constituição de bolso", com caráter emergencial e finalidade de reger a transição constitucional do país, evitando a desordem (BONAVIDES e ANDRADE, 1991). Entretanto, importa dizer que o caráter precário desse ordenamento jurídico, surgido para tapar o vácuo constitucional existente entre a derrubada do regime monárquico e a instituição constitucional do regime republicano, em nada afetava o vigor de tais normas enquanto não se promulgasse a nova Constituição. Além disso, essas mesmas normas exerceriam forte influência nos debates do

\footnotetext{
${ }_{102}$ Aristides Lobo (Ministério do Interior), Rui Barbosa (Ministério da Fazenda), Benjamin Constant (Ministério da Guerra e Ministério de Instrução Pública, Correios e Telégrafos), Eduardo Wandenkolk (Ministério da Marinha), Campos Salles (Ministério da Justiça) e Quintino Bocaiúva (Ministério da Agricultura e Ministério das Relações Exteriores).

${ }^{103}$ Poder-se-iam destacar como medidas dignas de nota na fundação do regime republicano brasileiro a declaração da laicidade do Estado, oficialmente separado da Igreja (Decreto 119-A, 07.01.1890) e a instituição do sufrágio universal (Decreto ${ }^{\circ}$ 06, de 19.11.1889).
} 
processo constituinte que se seguiria e, em muitos casos, serviriam mesmo como ponto de partida das discussões constituintes.

Um bom exemplo disso seria aquele que pode ser encarado como o principal objeto de discussão em torno da qual girou a Constituinte: o federalismo. Com efeito, a postura do governo provisório central quanto à fixação das atribuições dos governos estaduais desagradava, de certa forma, aos setores mais descentralizadores da sociedade. Isso porque, muitas vezes, o poder central, por meio de seus decretos, atuava no sentido de diminuir as atribuições do governo estadual e, mesmo quando atuava no sentido contrário, isto é, na ampliação de tais poderes, desagradava por implicitamente se reservar o poder de estabelecer os contornos dessas atribuições, reservando-se, em outras palavras, a faculdade de submeter os limites do poder estadual ao seu próprio poder. O governo central fazia-o acreditando que, apesar dessa tênue centralização, mantinha-se o caráter federativo do regime instituído, com o que, entretanto, não concordavam esses setores mais descentralizadores, que entendiam que tal postura do governo central não seria condizente com a idéia de federalismo que se pretendia ver implantada no país.

\subsection{A dupla tensão política que marcou o processo constituinte.}

Com isso, como bem nota LEITE, "o processo do qual resultou a Constituição de 1891 encontrava-se em meio a duas tensões, não necessariamente distintas: a tensão entre o Governo Provisório e o Congresso Constituinte, e o confronto entre as idéias unionistas e federalistas" (2003:34).

Como diz o autor, não se trata necessariamente de duas tensões distintas, mas, para melhor compreendê-las, analisemos cada uma delas separadamente.

\subsubsection{A tensão entre Governo Provisório e Congresso Constituinte.}

Quanto à tensão existente entre Governo Provisório e Congresso Constituinte, quando da instauração deste, aquele exercia duas importantes funções políticas. Não só era o agente responsável pelo completo desmantelamento dos resquícios do aparato monárquico, como ainda se encarregava da condução do processo constituinte. Quanto a esta segunda função, a condução do processo constituinte, vê-se que o Governo Provisório poderia ter agido de diversas maneiras, com diferentes graus de profundidade. Poderia tãosomente contentar-se com a convocação democrática dos constituintes. No entanto, nota-se 
que o Governo Provisório não se satisfez com isso, conduzindo, efetivamente, o processo constituinte. E o conduziu sob diversos aspectos.

Primeiramente, a já citada edição de leis que funcionaram como um ordenamento jurídico provisório ou uma "Constituição de bolso", embora sabidamente provisórias, retirou de fato a atribuição do Congresso Constituinte convocado de regular imediatamente a transição para o regime republicano. Com efeito, se não houvesse esse ordenamento provisório, caberia ao Congresso o estabelecimento das condições jurídicas da transição constitucional, as quais, pela existência de tal ordenamento, acabaram sendo estabelecidas pelo Governo Provisório.

Além disso, a própria convocação da Constituinte coube também ao Governo Provisório, que foi quem estabeleceu tanto a data para a eleição como as regras do processo eleitoral. Aqui vale lembrar que as eleições foram convocadas para 15 de setembro de 1890, portanto, quase um ano após a Proclamação da República, de maneira que se prolongou relevantemente o período em que o país estaria regido pela "Constituição de bolso" do Governo Provisório.

Por fim, um último aspecto bastante decisivo da tentativa de influência do Governo Provisório no processo constituinte foi a apresentação do Projeto de Constituição sobre o qual os constituintes deveriam deliberar. Esse ponto merece um destaque maior, cabendo aqui talvez uma pequena reconstituição da formação desse projeto.

Menos de um mês após a Proclamação da República, em 03 de dezembro de 1889, o Governo Provisório editou aquele que pode ser considerado o marco inicial dos trabalhos constituintes. Trata-se do decreto n. ${ }^{\circ} 29$, que instituiu uma Comissão e a incumbiu da elaboração do Anteprojeto de Constituição. Por ser composta por cinco membros, tal Comissão ficaria notoriamente conhecida como a Comissão dos $\operatorname{Cinco}^{104}$. Nota-se que a Comissão dos Cinco tinha uma composição relativamente homogênea, uma vez que todos os seus membros eram juristas e antigos membros do Partido Liberal convertidos às idéias republicanas por volta de 1870. Essa homogeneidade poderia ser considerada uma sinalização da dupla pretensão do Governo Provisório no Anteprojeto emanado da

104 Joaquim Saldanha Marinho era o presidente da Comissão, Américo Brasiliense, o vice-presidente, e Antonio Luiz Dos Santos Werneck, Francisco Rangel Pestana e José Antonio Pereira de Magalhães Castro, os demais componentes. 
Comissão dos Cinco: não só ponto de partida para as discussões constituintes, mas também condensação da idéia do Governo Provisório de Constituição republicana.

A edição do decreto $\mathrm{n}^{\mathrm{o}}$ 78-B, em 21 de dezembro 1889, engrandeceu a atribuição confiada à Comissão dos Cinco, instituída alguns dias antes. Esse decreto designava a data da eleição geral da Assembléia Constituinte para o dia 15 de setembro de 1890 e o início de seus trabalhos para 15 de novembro de 1890. Dessa forma, entre a data de instituição da Comissão e o início dos trabalhos da Assembléia Constituinte, transcorreria um prazo de quase um ano. Assim, considerando-se as pressões políticas para o retorno do país à legalidade, o trabalho prévio da Comissão teria então influência decisiva no processo constituinte.

Instalada a Comissão, estabeleceu-se que, numa fase prévia, cada membro, excetuado o presidente, apresentaria individualmente o seu projeto como ponto de partida para as discussões. Apenas três projetos foram apresentados ${ }^{105}$, pois, além da exceção do presidente, Santos Werneck e Rangel Pestana apresentaram um projeto conjunto. Após isso, a Comissão discutiu dispositivo por dispositivo de cada um dos projetos, aprovando-os ou

\footnotetext{
${ }^{105}$ Aqui cabe um breve resumo de cada um dos três projetos apresentados, publicado em artigo no Estado de S. Paulo, no dia 24 de fevereiro de 1915:

"O projeto Américo Brasiliense constituía as antigas províncias em Estados, com seus atuais limites. Admitia a intervenção da União nos Estados, em caso de perturbação interna, quando "requisitada pelas autoridades legalmente constituídas". O Poder Legislativo competia a duas Câmaras: o Senado, com quatro senadores por Estado, eleitos por seis anos pelas legislaturas estaduais; a Câmara dos representantes, com mandato por quatro anos e eleita por sufrágio direto. O Presidente da Republica, cujo período duraria quatro anos, seria escolhido por eleição indireta, com eleitores especiais. Os ministros compareceriam ás câmaras. O Judiciário teria á sua frente uma "Corte Suprema de Justiça", composta de juizes eleitos pelas legislaturas estaduais, dando cada Estado um juiz.

O projeto Werneck-Pestana compunha a federação de Estados, distrito federal, províncias e territórios. No caso de perturbação interna, a intervenção se daria a pedido do "governo de Estado". Discriminando as rendas publicas, entregava o imposto de exportação aos Estados e o de importação á União. Autorizava os Estados a organizarem milícias, podendo a União mobilizá-las. Pelo artigo 47, abolia o recrutamento militar forçado e estabelecia o sorteio, em falta de voluntários, o que veio a figurar na Constituição definitiva. Determinava o arbitramento obrigatório para as questões internacionais (art. III). O Legislativo compreendia uma câmara dos Deputados eleita por três anos, e um Senado, com três senadores por Estado, eleitos diretamente pelo eleitorado, durando o mandato nove anos. Quanto ao Executivo, o presidente, eleito por um eleitorado especial, exerceria o cargo durante sete anos, não podendo ser reeleito em tempo algum. O regime é nitidamente presidencial: os secretários ou ministros não compareceriam ao Congresso, entendendo-se com este por escrito. À cabeça do Judiciário, um "Supremo Tribunal de Justiça", cujos membros seriam eleitos pelo Senado, sem nenhuma intervenção do Presidente da Republica.

O projeto Magalhães Castro dividia o território nacional em Estados e territórios. Exerceriam o Poder Legislativo a câmara dos Deputados, eleita por três anos, e o Senado, com senadores eleitos pelas legislaturas dos Estados e por seis anos. O Presidente e o Vice-Presidente da Republica, eleitos pelas municipalidades, receberiam o mandato por cinco anos, podendo obter reeleição passados dois períodos. Um "Supremo Tribunal de Justiça" teria os seus juizes eleitos pelo Congresso e escolheria o procurador geral, que poderia denunciar o Presidente da Republica".
} 
rejeitando-os, e, assim, em 30 de maio de 1890, foi entregue o projeto unanimemente aprovado pela Comissão dos Cinco $^{106}$.

Encaminhado pelo Marechal Deodoro a seus ministros, o projeto da Comissão seria cuidadosamente revisto, sendo Rui Barbosa notadamente o líder desse trabalho de revisão. Essa revisão não abordou apenas aspectos formais, adentrando questões materiais significativas da nova organização constitucional do país ${ }^{107}$, especialmente no que tange à intervenção federal (art. $6^{\circ}$ ) e à declaração de direitos (art. 72).

Como se pode ver, o Governo Provisório, de acordo com seu projeto político, procurou influenciar e até mesmo direcionar a elaboração da Constituição. E, dentre outros meios, exerceu tal influência na maneira pela qual convocou a Assembléia Constituinte, instituiu a Comissão dos Cinco e ensejou a revisão ministerial do projeto da Comissão.

\subsubsection{A tensão entre unionistas e federalistas.}

Além da tensão política entre o Governo Provisório e o Congresso Constituinte, uma outra, não necessariamente distinta, também permeou o processo constituinte. Trata-se da tensão entre duas correntes políticas em que se dividia a maioria absoluta dos constituintes: os unionistas e os federalistas.

Os unionistas defendiam a atribuição de maiores poderes à União. Note-se que essa tendência à centralização do poder não significava que esse grupo fosse contra o sistema federalista. Ao contrário, era defensor de tal sistema, apenas entendendo que sua melhor aplicação seria feita de uma maneira moderada, atenuada, deixando-se uma esfera razoável de atuação ao poder central.

\footnotetext{
${ }^{106}$ Segue uma breve análise do projeto apresentado:

"as antigas províncias passaram a ser consideradas Estados; não se falava em territórios, porque o Dr. Magalhães Castro cedeu a empenhos do governo provisório e abandonou sua primitiva opinião. Na distribuição das rendas prevaleceu o projeto Werneck-Pestana; mas entendeu-se dever suprimir os impostos de exportação, a datar de 1897. A câmara dos Deputados teve a legislatura fixada em três anos; o Senado, eleito por sufrágio direto dos eleitores, prolongando-se o período por nove anos, como sugeriram Werneck e Pestana. O mandato do Presidente da República reduziu-se a cinco anos, de conformidade com a lembrança de Magalhães Castro; mas preferiu-se a eleição por eleitorado especial, a exemplo dos Estados Unidos e da Argentina. Os secretários de Estado não podiam comparecer ás sessões do Congresso; só iriam ás comissões prestar esclarecimentos. Enfim, no Judiciário, determinava-se que o Supremo Tribunal de Justiça se compusesse de quinze juizes, nomeados pelo Senado, sem interferência do Poder Executivo: é o judicioso processo da Constituição suíça."

${ }^{107}$ Muitas vezes se diz, com razão, que Rui Barbosa seria o verdadeiro "autor" do projeto constitucional encaminhado à Assembléia Constituinte. Para se ter uma idéia mais clara de quanto do projeto constitucional se deve à Comissão dos Cinco e o quanto se deve a Rui Barbosa, recomenda-se a leitura do trabalho intitulado $O$ que é de Rui de Pedro Calmon, encontrado em Prefácio à BARBOSA, RUI. "Obras Completas de Rui Barbosa”, vol. XVII, Tomo I, Ministério da Educação e Saúde, 1890, pp. XV-XXIII.
} 
De outro lado, o grupo denominado federalista propugnava uma maior descentralização, com ampla autonomia do poder estadual, deixando à União apenas as atribuições estritamente necessárias a sua existência. Buscando dar legitimação teórica para seus anseios descentralizadores, surgiram algumas estranhas idéias, tal como a "teoria da dupla soberania", de Campos Salles, um dos principais líderes dos federalistas. A teoria dizia que não apenas a União era soberana, mas também o eram cada um de seus Estados.

No interior do grupo de federalistas, surgiu ainda um subgrupo, não muito numeroso, que defendia o federalismo levado aos seus limites, corrente que seria denominada ultrafederalista.

Logo na discussão do primeiro artigo do Projeto da Constituição, que vedava o direito de secessão, já se inaugurou o embate entre unionistas e federalistas. A questão da autonomia estadual, por sua vez, foi um debate que atravessou quase todo o processo constituinte. Os unionistas queriam tratar na Constituição Federal de diversos assuntos que os federalistas entendiam que deveriam apenas ser cuidados nas Constituições estaduais, de acordo com a autonomia de cada um dos Estados. Isso explica o fato de muitos debates não adentrarem em aspectos materiais do objeto tratado, retendo-se no aspecto formal da conveniência de que tal objeto fosse regulado ou não pela Constituição Federal.

Note-se, por fim, que, como se disse, as tensões entre Governo Provisório e Congresso Constituinte e entre unionistas e federalistas não são necessariamente tensões distintas. Mais correto seria dizer tratar-se de uma dupla tensão. Com efeito, pelos decretos editados e pelo projeto constitucional emanado do Governo Provisório, verifica-se um forte caráter unionista em suas propostas. Tanto é assim que Rui Barbosa era não apenas um dos principais líderes do Governo Provisório como um dos principais líderes dos constituintes unionistas.

Passemos agora ao capítulo seguinte, no qual se buscará focar o debate constituinte que mais de perto interessa à presente pesquisa, a questão da estadualização ou federalização das terras devolutas.

\subsection{A Comissão dos 21.}


Em 22 de junho de 1890, a publicação do decreto $\mathrm{n}^{\mathrm{o}} 510^{108}$ confere vigor, provisório e parcial, ao Projeto de Constituição do Governo Provisório, elaborado pela Comissão dos Cinco e revisto pelos ministros do Governo Provisório, ainda não avaliado pelo Congresso Constituinte, que nem sequer havia iniciado seus trabalhos. $\mathrm{O}$ vigor conferido pelo decreto era provisório, pois apenas duraria enquanto não definitivamente aprovada a Constituição Federal, e era parcial, uma vez que só se referia "à dualidade das Câmaras do Congresso, à sua composição, à sua eleição e à função, que são chamadas a exercer, de aprovar a dita Constituição" (art 3º, do dec. $\left.n^{\circ} 510\right)$.

Além de dar vigor parcial ao Projeto do Governo Provisório, o decreto $\mathrm{n}^{\mathrm{o}} 510$ abandonou a idéia inicial de Constituinte monocameral e concedeu poderes especiais ao Congresso Nacional para julgar a Constituição, convocando as eleições dos representantes constituintes para o dia 15 de setembro de 1890, dia em que efetivamente ocorreram.

O Congresso Constituinte seria composto por duas casas: a Câmara dos Deputados, que contava com 205 deputados, e o Senado Federal, com 63 senadores. Pouco antes da instalação do Congresso Constituinte, que se daria em 15 de novembro de 1890 , primeiro aniversário da Proclamação da República, a Câmara dos Deputados e o Senado Federal decidiram instituir uma comissão com representantes de cada uma das casas ${ }^{109}$ para elaboração conjunta de um projeto de Regimento Comum, o qual entraria em vigor provisoriamente em 14 de novembro de 1890 e, depois de discutido e votado, definitivamente em 21 de novembro de 1890.

Composto por oito capítulos, o Regimento do Congresso Nacional dedicava apenas os dois últimos à elaboração da Constituição, sendo os outros seis referentes aos trabalhos do Poder Legislativo. Ao se analisar o Regimento, nota-se uma acentuada

\footnotetext{
${ }^{108}$ Transcrevem-se aqui as disposições do decreto n. ${ }^{\circ} 510$ :

“Art. $1^{\circ}$ É convocado para 15 de novembro do corrente ano o primeiro Congresso Nacional dos representantes do povo brasileiro, procedendo-se a sua eleição aos 15 de setembro próximo vindouro.

Art. $2^{\circ}$ Esse Congresso trará poderes especiais do eleitorado, para julgar a Constituição que neste ato se publica e será o primeiro objeto de suas deliberações.

Art. $3^{\circ}$ A Constituição publicada vigorará desde já unicamente no tocante à dualidade das Câmaras do Congresso, à sua composição, à sua eleição e à função, que são chamadas a exercer, de aprovar a dita Constituição, e proceder em seguida na conformidade das suas disposições".

${ }^{109}$ Os representantes da Câmara do Deputados foram Gabriel de Paula Almeida Magalhães (Minas Gerais), José Alvelino Gurgel do Amaral (Ceará), Dionisio Manhães Barreto (Rio De Janeiro), e os do Senado Federal Prudente José de Moraes Barros (São Paulo), Eliseu de Souza Martins (Piauí) e João Pedro Belfort Vieira (Maranhão).
} 
preocupação com a celeridade dos trabalhos constituintes, certamente pela já citada pressão pelo retorno do país à legalidade ${ }^{110}$.

Assim, visando-se à celeridade do debate constituinte, o art. $57^{111}$ do Regimento do Congresso Nacional criava uma comissão de 21 membros e nela centralizava os trabalhos constituintes. Essa comissão ficaria notoriamente conhecida como a Comissão dos 21. Cada membro representaria um Estado e seria eleito separadamente por ele, método de composição, veementemente criticado por alguns constituintes ${ }^{112}$, que já sinalizaria o viés federalista da Comissão. O parecer apresentado pela Comissão seria debatido pelo plenário do Congresso em duas discussões; a primeira votação se faria por artigos, e a segunda, de maneira global, com a exceção das emendas, as quais seriam sempre votadas separadamente (art. 58) ${ }^{113}$.

\footnotetext{
${ }^{110}$ Interessante observação foi feita por Aurelino Leal, que lembra o importante papel da imprensa nessa pressão pela volta à legalidade, especialmente de dois dos principais jornais de então, Diário de Notícias e $O$ País. Mais adiante, o autor lembra, perspicazmente, que esses órgãos seguiam orientação, respectivamente, de Rui Barbosa e Quintino Bocaiúva, que, por serem membros do Governo Provisório, defendiam a manutenção integral do Projeto apresentado ao Congresso (LEAL, 2002:223).

111 “Art. 57 - O Congresso elegerá uma Comissão especial de 21 membros para dar parecer sobre a Constituição.

$\S 1 .^{\circ}$ - A representação de cada Estado e do Distrito Federal elegerá separadamente o membro que deva fazer parte desta Comissão.

$\S 2 .^{\circ}$ - O parecer da Comissão será impresso no Diário Oficial e distribuído em avulso pelos membros do Congresso.

$\S 3 .^{\circ}$ - Os votos divergentes, se os houver, serão designados pelas palavras - vencido com ou sem restrições ou em pareceres em separado.

$\S 4 .^{\circ}$ - Três dias depois da distribuição avulsa, será o parecer dado para Ordem do Dia, conjuntamente com a Constituição decretada".

${ }^{112}$ Dentre os críticos deste método de composição destaca-se o constituinte Costa Machado, que, quando da discussão do art. 57 do Regimento, se insurgiu contra seu critério geográfico:

"O que me parece é que os encarregados de confeccionar o Regimento, tratando de criar esta Comissão, quiseram render homenagem a todos os Estados, não quiseram ofender suscetibilidades, foi uma espécie de diplomacia. Mas é preciso que se compreenda uma coisa e é que nós, na Constituinte, não somos Deputados de Estado algum, somos Deputados de todos os Estados Unidos do Brasil". "Regimentos das Assembléias Constituintes do Brasil”, Subsecretaria de Arquivo. - Brasília: Senado Federal, Subsecretaria de Edições Técnicas, 1986, pp. 66-7.

113 “Art. 58 - O parecer e a Constituição sofrerão duas discussões, sendo a $1^{\mathrm{a}}$ por capítulos e a votação por artigos, e a $2^{\text {a }}$ discussão e votação englobadamente, salvo as emendas que serão votadas cada uma de per si. $\S 1 .^{\circ}$ - Terminada a $1 .^{\mathrm{a}}$ discussão, haverá um interstício de dois dias, o que começará a ser contado do dia em que tiver lugar a distribuição da Constituição com as emendas.

$\S 2 .^{\circ}$ - Na 2..$^{a}$ discussão poderão ser apresentadas ainda novas emendas, as quais, se forem aprovadas, sofrerão uma 3. ' discussão, finda a qual serão aprovadas ou rejeitadas sem subemendas".
} 
Apesar das críticas, a Comissão foi eleita em 22 de novembro de $1890^{114}$ e, menos de vinte dias depois, em 10 de dezembro de 1890, apresentou seu parecer.

Em geral, não foram muitas as mudanças apresentadas ao Projeto do Governo Provisório. Entretanto, algumas das mudanças sugeridas tocavam e abalavam pontos fundamentais do projeto, das quais uma interessa imensamente a esta pesquisa: a questão da federalização ou estadualização das terras devolutas.

\subsection{A questão fiscal no Congresso Constituinte.}

Antes de tratarmos propriamente da questão de terras no Congresso Constituinte, parece interessante a abordagem de uma outra questão fundamental no embate entre unionistas e federalistas: a questão fiscal.

Além de ser um dos pontos nodais do processo constituinte de 1891, a questão fiscal nos interessa por se relacionar com a discussão a respeito da propriedade das terras devolutas, na medida em que os federalistas a reivindicavam aos Estados federados para que, com sua venda, fizessem frente às novas despesas a eles atribuídas, as quais, segundo eles, não poderiam ser suportadas com o simples remanejamento das receitas fiscais.

Para tratarmos da questão fiscal na transição republicana, faz-se novamente obrigatória a referência ao trabalho de Wilma Peres Costa, intitulado A questão fiscal na transformação republicana - continuidade e descontinuidade. Vejamos, na esteira dessa pesquisa, como se deu a questão fiscal na Constituinte de 1891.

Durante o período imperial, houve forte centralização das atribuições fiscais. Essa centralização devia-se não tanto a uma pretensa força do poder central em se impor aos anseios fiscais centrífugos, mas sim à "estreiteza arrecadadora do Estado como um todo", sendo a arrecadação baseada quase que exclusivamente na tributação do comércio exterior. Com essa dependência, o Estado imperial demonstrava não só os limites que a ordem econômica e social escravista impunha à extração de impostos, como também sua incapacidade em tributar "a propriedade e a riqueza dos agentes econômicos privados", de que são exemplos os fracassos na introdução do imposto territorial e do de renda.

\footnotetext{
${ }^{114}$ A Comissão dos 21era composta por Francisco Machado (Amazonas), Lauro Sodré (Pará), Casimiro Jr. (Maranhão), Teodoro Pacheco (Piauí), Joaquim de Oliveira Catunda (Ceará), Amaro Cavalcanti (Rio Grande Do Norte), João Neiva (Paraíba), José Higyno (Pernambuco), Gabino Besouro (Alagoas), Oliveira Valadão (Sergipe), Virgílio Damásio (Bahia), Gil Goulart (Espírito Santo), Bernardino de Campos (São Paulo), João Batista Lapér (Rio De Janeiro), Ubaldino do Amaral (Paraná), Lauro Müller (Santa Catarina), Julio de Castilhos (Rio Grande Do Sul), João Pinheiro (Minas Gerais), Lopes Trovão (Distrito Federal), Leopoldo de Bulhões (Goiás), Aquilino do Amaral (Mato Grosso).
} 
Com a cessação das derrubadas periódicas dos governos provinciais, propiciadas ao governo central pelo exercício do Poder Moderador, foi possível observar a consolidação de "esferas de poder no plano dos estados", fundamentais para a convergência dos interesses regionais que, no plano econômico, vinham progressivamente se diferenciando a partir da década de 1870.

Não se pode esquecer, entretanto, que, embora estivessem os Estados federados unidos por um anseio descentralizador, a enorme diferenciação econômica e a extrema desigualdade entre eles se fariam sentir na Constituinte de 1891, em especial quanto às diferenças entre os potenciais de produção de recursos físcais.

Dito isso, vejamos rapidamente como ocorreu a discussão da questão fiscal no processo constituinte de 1891.

O projeto que saiu da Comissão dos Cinco, revisto pelo ministro Rui Barbosa, inovava o sistema fiscal imperial por definir explicitamente as competências tributárias exclusivas das esferas federal e estadual, deixando ainda uma área de competência cumulativa entre as duas esferas ${ }^{115}$.

${ }^{115} \mathrm{O}$ sistema fiscal é tratado pelo projeto basicamente entre seus arts. $6^{\circ}$ a 12 , os quais são a seguir transcritos: "Art.6 - É da competência exclusiva da União decretar:

$1^{\circ}$ - Impostos sobre a importação de procedência estrangeira;

$2^{\circ}$ - Direito de entrada, saída e estada de navios; sendo livre o comércio de cabotagem às mercadorias nacionais, bem como às estrangeiras que já tenham pago imposto de exportação;

$3^{\circ}$ - Taxas de selo;

$4^{\circ}$ - Contribuições postais e telegráficas;

$5^{\mathrm{o}}$ - A criação e manutenção de alfândegas,

$6^{\mathrm{o}}$ - A instituição de bancos emissores. (...)

Art. $8^{\circ}$ É da competência exclusiva dos estados decretar impostos:

$1^{\circ}$ - Sobre exportação de mercadorias que não sejam de outros estados;

$2^{\circ}$ - Sobre a propriedade territorial;

$3^{\circ}$ - Sobre a transmissão de propriedade.

Parágrafo $1^{\circ}-$ É isenta de impostos, no Estado por onde se exportar, a produção de outros estados.

Parágrafo $2^{\circ}$ - Em 1898, ou antes, se o Congresso deliberar, cessarão todos os direitos de exportação.

Parágrafo $3^{\circ}$ - Só é lícito a um Estado tributar a importação de mercadorias estrangeiras, quando destinadas ao consumo em seu território, revertendo porém, o produto do imposto para o Tesouro

Federal.

Art. $9^{\circ}$ - É proibido ao Estado tributar de qualquer modo ou embaraçar com qualquer dificuldade ou gravame regulamentar ou administrativo, atos, instituições ou serviços estabelecidos pelo Governo da União.

Art. $10^{\circ}$ - É vedado aos estados como à União:

$1^{\circ}$ - Criar impostos de trânsito pelo território de um Estado ou na passagem de um para outro sobre produtos de outros estados da República ou estrangeiros, e bem assim sobre os veículos de terra e água que os transportam.

$2^{\circ}$ - Estabelecer, subvencionar ou embaraçar o exercício de cultos religiosos.

$3^{\circ}-$ Prescrever leis retroativas.

Art. $11 \mathrm{o}$ - Nos assuntos que pertencerem concorrentemente ao Governo da União e aos governos dos estados, o exercício da autoridade pelo primeiro obsta a ação dos segundos e anula, de então em diante, as leis e disposições dela emanadas. 
Quando de sua análise pela Comissão dos 21, se fizeram sentir as divergências entre os Estados, representados igualitariamente na Comissão. Dentre os pontos do projeto mais criticados pela Comissão, dois se destacam. Primeiramente, a previsão de a União poder, em 1898, extinguir o imposto de exportação (art. $8^{\circ}, 3^{\circ}$, parágrafo $3^{\circ}$ ), principal fonte de arrecadação dos Estados. Além disso, ao questionar a razão da União em propor tal dispositivo, cogitou-se a intenção que ela teria em substituir o imposto de exportação pelo imposto territorial, o que não interessava às elites agrárias que representavam vários Estados na Comissão dos 21. Em segundo lugar, argumentou-se que somente o imposto de exportação não seria suficiente para fazer frente às novas despesas carreadas aos Estados, acabando a Comissão por propor, como disposição transitória, a concessão aos Estados de $10 \%$ sobre a arrecadação dos impostos de importação.

Além dessas propostas, foi muito importante uma outra, que se poderia classificar como ultrafederalista, de autoria de Júlio de Castilhos. Ele aceitava a enumeração das receitas privativas da União (art. $6^{\circ}$ ), mas entendia que deveria ser dada liberdade aos Estados para que pudessem fixar quaisquer outros impostos que não aqueles privativos da União, desde que tal fixação não fosse contrária às disposições da Constituição ${ }^{116}$. Sua única concessão à União seriam os casos extraordinários, nos quais ela poderia taxar a renda dos Estados ${ }^{117}$.

Quando da discussão plenária das propostas, a proposta ultrafederalista de Júlio de Castilhos contou com grande adesão, recebendo expressiva votação, sendo rejeitada apenas por 103 votos a favor versus 123 contra. Também por pequena diferença foi rejeitada a proposta da Comissão dos 21, dando aos Estados 10\% dos impostos de importações (123 votos contra e 98 a favor).

\footnotetext{
Art. $12^{\circ}$ - Além das fontes de receita discriminadas nos arts. 60 e 80 é lícito à União, como aos estados, cumulativamente ou não, criar outros quaisquer, não contravindo o disposto nos arts. $7 \mathrm{o}, 9 \mathrm{o}$ e $10^{\circ}$ ".

${ }^{116}$ Tal concepção encontra-se em sua proposta de reforma do art. $8^{\circ}$, com a seguinte redação:

"Art. $8^{\circ}$ - É da competência exclusiva dos estados decretar qualquer imposto que não esteja compreendido no artigo $6^{\circ}$ e que não seja contrário às disposições da Constituição".

117 “Art. 12 - Nos casos extraordinários de calamidade pública poderá o governo da União taxar a renda de cada um dos estados, devendo ser igual para todos a porcentagem.

Parágrafo 10 - Quando forem insuficientes as fontes de receita discriminadas no art. 6o para concorrer ao serviço da dívida nacional, poderá também o governo da União lançar uma taxa permanente sobre a renda dos estados, sem distinções".
} 
Como fatores apontados como causa da vitória dos interesses da União, destacamse a falta de coesão entre as propostas descentralizadoras ${ }^{118}$ e os votos dos Estados exportadores, especialmente São Paulo. Além disso, a defesa de Rui Barbosa, ali como representante da Bahia, foi também fundamental para a vitória unionista sobre o ímpeto descentralizador ${ }^{119-120}$.

\subsection{A questão de terras no Congresso Constituinte.}

Voltemos agora à questão da propriedade das terras devolutas. Como dizíamos, de um modo geral não foram muitas as mudanças apresentadas ao Projeto do Governo Provisório. Apesar disso, algumas das mudanças realizadas abalavam pontos basilares do projeto governamental. Dentre elas estava a questão da propriedade das terras devolutas.

Com clara tendência unionista, o Projeto do Governo Provisório dispunha que a propriedade das terras devolutas ficaria reservada à União, reservando-se a ela a faculdade de distribuir aos Estados certas extensões de terras por meio de lei ordinária do Congresso Nacional. Tal distribuição seria condicional, pois, se dentro de determinado prazo, também estabelecido por lei, os Estados não conseguissem povoar nem colonizar as terras cedidas, a propriedade seria devolvida à União.

Assim, a redação do art. 63 do Projeto do Governo Provisório tinha a seguinte redação:

\footnotetext{
118 "Pesava também contra as posições que queriam reduzir os poderes fiscais da União o fato de que tinham suas forças divididas, a bancada riograndense vetando a idéia de quotas-parte dos impostos de importação para a renda dos estados" (COSTA, 1998:161).

119 "Os argumentos de Rui Barbosa tiveram grande peso no resultado da votação. Eles vinham de um aguerrido federalista desde os tempos da monarquia, mas que agora, na posição de Ministro da Fazenda, tendia a ver com clareza os limites estruturais que incidiam sobre a base fiscal do país e, mais do que isso, os constrangimentos que a dívida pública impunham sobre as finanças nacionais. Paradoxalmente, o endividamento servia aos interesses que militavam contra o enfraquecimento da União" (COSTA 1998:162).

${ }^{120}$ Parte desta defesa é a seguir reproduzida, especialmente no que tange ao argumento de Rui Barbosa de que os federalistas precisavam se conscientizar que a União preexistia aos estados federados e que esses apenas poderiam existir dentro dela:

"A questão para nós, que adotamos a forma federativa; a primeira necessidade, o ponto de partida de todas as necessidades, está em assegurar a existência independente da União Federal. É depois de ter assegurado à coletividade nacional os meios de subsistir, forte, tranqüila, acreditada, que havemos de procurar se ainda nos sobram recursos que proporcionem às partes desse todo a espera de independência local anelada por eles. (...) Partamos, senhores, deste preliminar: os estados hão de viver na União e não podem subsistir fora dela. A União é o meio, a base, a condição absoluta da existência dos estados (...) Se há no Brasil estados mais fortes e estados menos fortes, mais fracos e menos fracos, a condição da existência de todos, fracos ou fortes, grandes ou pequenos, pobres ou ricos, é a sua coesão, a solidariedade de sua vida integral no seio da Federação, organizada segundo os meios práticos que a experiência nos indica".
} 
“Art. 63. Uma lei do Congresso Nacional distribuirá aos

Estados certa extensão de terras devolutas, demarcadas à custa delles, aquém da zona da fronteira da República, sob a cláusula de as povoarem e colonizarem dentro em determinado prazo, devolvendo-se, quando essa ressalva se não cumprir, à União, a propriedade cedida.

Paragrapho Único. Os Estados poderão transferir, sob a mesma condição, essas terras, por qualquer título de direito, oneroso ou gratuito, a indivíduos ou associações que se proponham a povoal-as e colonizal-as" (Diário do Congresso Nacional, 5 de fevereiro de 1891, pg. 367).

Vê-se que, em seu projeto, o Governo Provisório partia da idéia de que o país já existia, isto é, a União preexistia aos Estados, sendo já as terras devolutas sua propriedade, fato este em que o sistema federalista não precisaria interferir.

A Constituinte, entretanto, alterou profundamente o projeto, partindo de idéia quase que totalmente oposta, isto é, "convencida de que não estava legislando em nome de um paiz que já existia e sim em nome de Estados que concordavam em dar existência à União, mas apenas com o estrictamente necessário para viver" (ROURE, 1918:176).

Com efeito, logo depois de sua publicação, surgiram diversas manifestações contrárias ao projeto. Por exemplo, em representação dirigida à Assembléia Nacional, antes mesmo do parecer da Comissão dos 21, o Apostolado Positivista propôs a substituição da redação do art. 63 pela seguinte:

"Art. 63. As terras devolutas pertencem aos estados em que se acharem, exceptuadas as que forem necessárias para os serviços federaes" (Diário do Congresso Nacional, 18 de fevereiro de 1891, pg. 563).

Logo no início das reuniões da Comissão dos 21, manifestou-se a forte tendência de entregar aos Estados a propriedade das terras devolutas. Tal tendência se confirmou e, 
em seu parecer, a Comissão alterou profundamente, nesse ponto, o Projeto do Governo Provisório, justificando de maneira relativamente extensa tal alteração. O próprio parecer admite que a decisão não foi unânime, transparecendo a divergência em torno do tema.

"A maioria da commissão, convencida de que da autonomia reconhecida aos Estados, pelo novo regimen, decorre o direito às terras devolutas comprehendidas dentro dos seus respectivos limites, como parte que são dos seus territórios, opinou que o art. 63 fosse substituído pelo seguinte: 'Pertencem aos Estados as terras devolutas situadas nos seus respectivos territórios, cabendo somente à União as que existem nas fronteiras nacionaes, comprehendidas dentro de uma zona de cinco léguas e as que forem necessárias para as estradas de ferro federaes"” (apud ROURE, 1918:178).

Interessante notar que, com relação ao projeto encarado como um todo, esse parecer não se deteve muito em explicações, não as dando quanto a grande parte das alterações efetuadas pela Comissão, cuidando apenas daquelas de maior importância. Assim, o fato de o parecer se deter longamente na questão da propriedade das terras devolutas mostra a consciência dos constituintes da inescapável relevância do tema em debate. $\mathrm{Na}$ fundamentação da proposta de alteração do projeto, a Comissão usou dois importantes argumentos para a estadualização das terras devolutas.

O primeiro seria que a venda das terras devolutas estaduais garantiria aos Estados uma renda extra que faria frente aos novos encargos a ele atribuídos com o federalismo. Com efeito, o federalismo encarregou os Estados, agora autônomos, de inúmeras atribuições e serviços que antes competiam ao poder central. Com isso, surgiu o receio de que os Estados não possuíssem renda suficiente para arcar com essas novas imposições. Dessa maneira, a Comissão dos 21 pretendia que a venda das terras devolutas ajudasse na resolução desse problema. 
"Sendo incontestável a necessidade de alargar as fontes de receita dos Estados, a emenda em questão de alguma sorte attende a essa necessidade, facultando aos Estados a venda de suas terras devolutas, da qual tirarão elles abundantes recursos para occorrer aos seus pesados encargos futuros" (Diário do Congresso Nacional, 18 de fevereiro de 1891, pg. $567)$.

Uma segunda razão usada pela Comissão para fundamentar a escolha pela estadualização das terras devolutas é a do tratamento diferenciado dispensado pelo governo central aos Estados. Alegou-se que, se o Projeto do Governo Provisório fosse aprovado e as terras devolutas ficassem como propriedade da União, esta teria o poder de concedê-las ou não aos Estados, os quais ficariam à mercê de seu tratamento discriminatório. Encarada como estreitamente ligada à questão de terras, também a colonização ficaria sujeita a esse tratamento discriminatório, o que preocupava os poderes estaduais e, conseqüentemente, os membros da Comissão dos 21.

"Os interesses da colonização, que affectam mais directamente os Estados, ficam também melhor garantidos pela nova disposição, que ainda tem a vantagem de evitar a desigualdade com que a União poderia occupar-se desse importante ramo de serviço" (Diário do Congresso Nacional, 18 de fevereiro de 1891, pg. 564).

Por fim, vale destacar a influência do constitucionalismo norte-americano, com o uso do exemplo do federalismo nos Estados Unidos, onde as terras devolutas pertencem aos Estados federados. A comparação é feita sem o cuidado de mostrar as diferenças e peculiaridades entre os contextos históricos e os processos que levaram ao federalismo brasileiro e norte-americano, o que leva novamente a se pensar que a Constituinte encarava que, no Brasil, como nos Estados Unidos, eram os Estados que consentiam em dar existência à União. 
"Nos Estados Unidos da América do Norte prevaleceu o princípio de pertencerem aos Estados as terras devolutas; e, si hoje a União alli se acha no domínio dellas, é porque as houve por compra ou conquista aos Índios - por cessão dos estados, gratuita ou onerosa" (Diário do Congresso Nacional, 18 de fevereiro de 1891, pg. 565).

Quando submetida à apreciação do plenário do Congresso Constituinte, a proposta de estadualização das terras devolutas encontrou, de um lado, inúmeros e ardorosos defensores, e, de outro, embora não tão numerosos, críticos igualmente ardorosos. Adiante se tentará reconstruir os principais momentos dessa disputa.

A primeira discussão a respeito do art. 63 iniciou-se na sessão de 08 de janeiro de 1891. O constituinte Lauro Sodré foi o primeiro a apresentar sua proposta. Representante do Estado do Pará, Sodré era capitão militar e ex-secretário de Benjamin Constant quando ministro da Guerra e, depois, da Instrução Pública. Assim, logo se pode ver sua ligação com o Apostolado Positivista. E, realmente, a emenda apresentada era mera adaptação daquela apresentada pelo Apostolado Positivista antes mesmo do parecer da Comissão dos 21, atribuindo as terras devolutas aos Estados em que se encontrarem, com a exceção daquelas indispensáveis aos serviços federais.

$\mathrm{Na}$ mesma sessão, pronunciou-se o deputado sul-rio-grandense Antão de Faria, também favorável à estadualização das terras devolutas. Vale lembrar que Antão de Faria, republicano histórico, ativo participante da propaganda republicana no Rio Grande do Sul, havia sido nomeado, logo após a Proclamação da República, superintende extraordinário do Serviço de Terras daquele Estado. Defendeu sua posição nos seguintes termos:

"O art. 63 do projecto dá à União o domínio das terras devolutas (...). Alguns representantes consideram as terras devolutas um patrimônio nacional que deve ser zelosamente guardado em benefício futuro da collectividade brasileira e julgam uma iniqüidade dar aos Estados o domínio dessas 
terras. Entre os que assim pensam acha-se o meu antigo e illustre correligionário Sr. Ubaldino do Amaral, senador pelo Paraná. Sinto estar em desaccôrdo com S. Ex., pois impugno o artigo do projecto constitucional e só aceitarei a emenda da comissão revisora se o Congresso não preferir a minha. Os illustres representantes que argumentam no sentido de demonstrar que a propriedade das terras devolutas deve caber à União lembram que há Estados onde não existem taes terras e que esses, adoptado o alvitre constante da emenda que formulei, ficariam em condições inferiores aos outros, sem as vantagens equivalentes às que para estes resultarão da posse desse patrimônio (...).

Si há estados onde não há terras devolutas, é porque tem a felicidade de tel-as todas povoadas e estão assim em melhores condições do que os demais (...).

A própria monarchia, pela lei de 24 de novembro de 1888 , já havia dado às províncias o producto da venda das terras devolutas" (Diário do Congresso Nacional, 18 de fevereiro de 1891, pg. 566).

Depois disso, juntamente com Muniz Freire, Antão de Faria propõe a seguinte emenda:

“Art. 63. As minas e as terras devolutas são do domínio dos Estados, sem prejuízo dos direitos da União a toda porção de território que precisar para defesa das fronteiras, para fortificações, para construcções e, em geral, para qualquer serviço público que dependa directa e exclusivamente de sua autoridade" (Diário do Congresso Nacional, 18 de fevereiro de 1891, pg. 567). 
Logo após esse discurso, sobe à tribuna mais um defensor da estadualização das terras devolutas, o pernambucano João Barbalho:

"Não posso comprehender dentro da circumscripção territorial dos Estados, territórios que pertençam a um poder extranho, ainda que seja esse poder a União, salvo os desapropriados para serviços federaes" (Diário do Congresso Nacional, 18 de fevereiro de 1891, pg. 567).

$\mathrm{Na}$ sessão seguinte, de 09 de janeiro de 1891, Homero Baptista propôs uma emenda pela qual a redação do art. 63 deixaria à União uma zona de cinco léguas de largura em toda a fronteira, lembrando que isso não era muito quando comparado com a faixa de dez léguas que a Lei de Terras dava ao governo imperial para defesa das fronteiras.

Ainda nesse mesmo dia, discursa o paraense Nina Ribeiro, criticando tanto a redação proposta pelo Governo Provisório, por considerá-la um "atentado contra todos os princípios federalistas", quanto a redação do parecer da Comissão dos 21 , por entender que ela "restringe demais o direito da União", além do que, "não se pode determinar com precisão quaes sejam, no correr dos tempos, as necessidades da União, os serviços que porventura tenha de satisfazer e que demandem uma certa porção de terreno" ${ }^{121}$. Tendo em consideração esses aspectos, propõe a seguinte redação ao artigo:

"São propriedades dos estados as terras devolutas situadas dentro de seus respectivos limites, cabendo à União somente

\footnotetext{
121 "Sr. Presidente, o art. 63 do projecto é um atentado contra todos os princípios federalistas. Eu não comprehendo como possam existir estados autônomos sem direito ao seu território. Estado sem território é uma entidade impossível de concepção, porque o estado é o governo da sociedade de um certo território. É o domínio deste que justifica o governo dos povos que o habitam. Nada pois justifica o disposto no art. 63 do projecto.

A comissão dos 21 propôz um substitutivo no qual consagra o princípio opposto ao do projecto, reconhecendo o direito dos estados às terras devolutas situadas nos respectivos territórios. Essa emenda restringe por demais, entretanto, o direito da União, pois só lhe concede cinco léguas de terras nas fronteiras, e as que forem necessárias para a construç̧ão de estradas de ferro. Não se pode determinar com precisão quaes sejam, no correr dos tempos, as necessidades da União, os serviços que porventura tenha de satisfazer e que demandem uma certa porção de terreno".
} 
as que forem necessárias para serviços federaes" (apud ROURE, 1918:184).

$\mathrm{Na}$ verdade, embora a fundamentação de Nina Ribeiro pudesse levar a pensar que sua sugestão seria conciliatória, vemos que ela se aproxima muito da de Lauro Sodré, quase com ela se confundindo.

Mais próximas da conciliação seriam as sugestões de emenda do alagoano Gabino Besouro e do sergipano Valladão, propondo que as terras devolutas fossem entregues aos Estados, reservando-se, entretanto, à União o direito de reavê-las quando fosse necessário.

Na sessão de 10 de janeiro de 1891, a posição de que as terras deveriam pertencer aos Estados, reservando-se à União as que fossem indispensáveis para serviços federais e obras de defesa, novamente seria defendida, agora por Assis Brasil.

No entanto, nesse mesmo dia surge o primeiro discurso defendendo a idéia de que as terras devolutas deveriam pertencer à União. E a voz que se ouviu foi a do representante mineiro Américo Lobo, que chegou a dizer que enxergava na atitude da Constituinte uma "tendência enormíssima para liquidar-se a propriedade privada da Nação Brasileira, isto é, para a divisão das terras públicas" e declarou preferir a redação do Projeto do Governo Provisório à da emenda, para que se deixasse a uma lei ordinária a solução da questão das terras devolutas.

Encerrados os debates da primeira discussão sobre a redação do art. 63, sua votação se realizou em 12 de janeiro de 1891, sendo rejeitadas as redações do Projeto do Governo Provisório e o substitutivo da Comissão dos 21, além da emenda de Lauro Sodré, tendo sido aprovada a emenda de Antão de Faria e Muniz Freire. Como já se viu, ela propunha que as terras devolutas fossem do domínio dos Estados, reservando-se à União os direitos de território necessários para a defesa das fronteiras, as fortificações, as construções e, em geral, para qualquer serviço público federal.

Na segunda discussão do art. 63, iniciada na sessão de 21 de janeiro de 1891, um outro constituinte se faz notar na defesa da propriedade da União das terras devolutas, o cearense Theodoreto Souto, que nos tempos do Império havia sido presidente das Províncias de Santa Catarina (1883) e do Amazonas (1884). O discurso de Souto tenta tornar indissociável a idéia da existência soberana de uma nação com sua propriedade 
territorial. Traçando um paralelo, diz que "a soberania territorial entra no direito público ao mesmo título que a propriedade entra no direito privado”, sendo, para ele, inconcebível a idéia de uma nação sem território. Adiante transcrevo parte do discurso:

"Um outro assumpto, sobre o qual também enviei uma emenda é, me parece, de alta gravidade, e se refere a questão dos terrenos devolutos, que, por uma emenda bruscamente apresentada, passaram a pertencer aos estados.

Ora, isso é absolutamente impossível e absurdo, contra o direito e a justiça, contra as leis fundamentaes e razão.

Senhores, vós estabeleceis na Constituição, e este é um princípio essencial, é um direito que faz parte da declaração dos direito, é uma dessas theses iniciaes que se chamava no tempo da Revolução Franceza o grande vestíbulo das Cartas Constitucionaes; vós estabeleceis que a propriedade é sagrada, mantida em sua plenitude, ou integralidade jurídicomoral e, pois, não pode ser absolutamente retirada nem ao indivíduo, nem a uma collectividade.

Mas, as terras devolutas em virtude de todas as leis anteriores, pela ocupação secular, por todos os princípios de direito já pertencem à União; logo, vós não podeis tiral-as da União para entregal-as aos estados.

Senhores, peço-vos que consulteis a sciência e a história, o direito e a philosophia e vos asseguro que não achareis nada igual.

O princípio cardeal é este: pertencem à União, isto é, ao Estado em sua collectividade, em sua unidade superior, moral e política, as terras que ninguém poude occupar; pertencemlhe as terras que deixaram de ser occupadas; pertencem-lhe as terras que ainda não estão occupadas; é uma tríplice cathegoria. (...) 
Senhores, o que fica sendo a União brazileira sem o seu território? O que fica sendo, por exemplo, essa porção de terrenos das Missões, objeto de litígio internacional? Respondei-me; a quem fica pertencendo essa zona chamada Missões, quando nós todos queremos que se a respeite nos limites de nossa propriedade e não queremos que nella se toque, pelo princípio superior da indivisibilidade do território nacional? (...)

Senhores, eu poderei estar em êrro, mas parece-me que a emenda aprovada contém o maior de todos os absurdos. Pretende-se fazer uma pátria sem um território, uma pátria abstrata, sem elementos materiaes, sem domínio nacional, que é a maior força de um povo, porque é a sua maior riqueza no presente e no futuro.

O que se pode fazer é declarar na Constituição, e neste sentido mando uma emenda, que a união cederá uma certa porção de terras devolutas. Soberania sem território é uma idéia oca, é um sonho. Só o federalismo, levado à altura do separatismo, pode chegar até ahi”. (Diário do Congresso Nacional, 21 de fevereiro de 1891,pg. 576 e 577).

É interessante notar a reação de alguns constituintes, que não foram identificados, ao discurso de Souto. Um o interrompe para dizer que "nessa questão de terras V. Ex. está mais atrazado do que a monarchia, que nos havia dado a importância da venda", referindose certamente à lei de 24 de novembro de 1888, citada, inclusive, por Antão de Faria em seu discurso. Mais adiante, Souto será mais uma vez interrompido para ser acusado de ser contrário às idéias federalistas, com um constituinte acusando-o de querer "uma república sem federação", ao que outro responde, ironicamente, “então votemos já contra o art. 10".

Souto apresentou emenda cuja redação em muito se assemelhava àquela do Projeto do Governo Provisório, entregando as terras devolutas ao domínio da União, podendo esta, por meio de lei do Congresso, distribuir aos Estados, dentro dos seus limites, 
certa extensão, com a condição de que eles as demarcassem e povoassem em determinado prazo, no fim do qual, caso não cumprida a condição, as terras seriam restituídas à União.

Outra emenda no mesmo sentido foi apresentada por Américo Lobo, restabelecendo o disposto no art. 63 do Projeto do Governo Provisório. No entanto, essa era mais radicalmente centralizadora, pois suprimia o parágrafo único do projeto original, que facultava aos Estados ceder, a título oneroso ou gratuito, essas terras. Tratava-se, portanto, de redação mais centralizadora que aquela apresentada pelo projeto original.

Apesar dos esforços contrários, a mesma sorte reservada ao art. 63 na primeira discussão the foi conferida na segunda, sendo aprovada a emenda de Júlio de Castilhos, que tinha o mesmo teor da de Antão de Faria e Muniz Freire, ficando a redação do artigo constitucional, renumerado para art. 64, com a seguinte redação:

“Art. 64. Pertencem aos Estados as minas e terras devolutas situadas nos seus respectivos territórios, cabendo à União somente a porção do território que for indispensável para a defesa das fronteiras, fortificações, construcções militares e estradas de ferro federaes.

Parágrafo único - Os próprios nacionaes, que não forem necessários para o serviço da União, passarão ao domínio dos Estados, em cujo território estiverem situados" (Diário do Congresso Nacional, 21 de fevereiro de 1891, pg. 578).

Aliás, como bem observa Roure, "a vontade de entregar as terras devolutas aos estados era tão grande, que a Assembléia ainda approvou outra emenda, no mesmo sentido, apresentada pelo Sr. Feliciano Penna" (1918:178).

Vendo sua posição derrotada na Assembléia Constituinte, alguns dos principais responsáveis pelo Projeto do Governo Provisório fizeram questão de frisar a contrariedade a que estavam sendo submetidos. José Hygino limitou-se a afirmar que votou pela conservação do domínio da União sobre as terras devolutas. Rui Barbosa, por sua vez, entregou uma declaração escrita na qual dizia: 
"Declaro ter votado contra todas as emendas que transferem para os estados o domínio das terras e próprios nacionaes e minas" (apud ROURE, 1918:185).

Além dele, também Quintino Bocaiúva fez questão de assinalar sua inconformidade:

"Declaro que votei contra a disposição constitucional que transferiu da União para os Estados o domínio das terras devolutas. Não sendo esta a única divergência do meu voto, assignalo-a, contudo, pela excepcional gravidade desta deliberação, na minha humilde opinião" (apud ROURE, 1918:185).

É eloqüente o fato de alguns dos principais nomes do Governo Provisório declararem de forma tão acentuada seu inconformismo com a solução adotada para a questão das terras devolutas. Isso parece demonstrar que eles tinham consciência de que, com essa alteração, boa parte da coerência e aplicabilidade da reforma por eles planejada fora posta em xeque.

\subsection{A inconstitucionalidade do Registro Torrens.}

Assim, vê-se que a vitória dos federalistas na Constituinte na questão de terras, com a entrega aos governos estaduais das terras devolutas, fez com que a política de terras fosse totalmente descentralizada. Sendo a alienação das terras devolutas considerada matéria de direito administrativo, ao permitir que os Estados organizassem como quisessem seus governos e administrações, a Constituição de 1891 acaba por comprometer fortemente a aplicação do Registro Torrens. Os Estados passaram a se reger, após 1891, por suas próprias leis, respeitadas as limitações constitucionais. Uma vez que o decreto que instituiu o sistema Torrens de registro foi uma lei do governo central, a obrigação de serem registradas por esse sistema as terras devolutas vendidas, na prática, sucumbiu, caindo em desuso o Registro Torrens na quase totalidade do território brasileiro. Nesse sentido, comenta Ruy Cirne Lima: 
"Se assim é, (...) como se concebe que a lei Torrens decretasse sumariamente a nulidade de um ato, que não lhe estava, nem lhe podia estar sujeito, mas que caía, ao invés, na alçada da legislação estadual?” (LIMA, 1954:76).

Aliás, não só na prática, mas também do ponto de vista jurídico-formal, ganhou força uma corrente doutrinária que entendia que a obrigatoriedade do Registro Torrens era inconstitucional, pela incompetência legislativa de o governo central tratar das terras devolutas, que, após a Constituição de 1891, não mais the pertenciam. Com isso, em 3 de agosto de 1895, o Supremo Tribunal Federal declarou a inconstitucionalidade da obrigatoriedade do Registro Torrens. Note-se que não se deve entender que o sistema Torrens de registro como um todo tinha sido declarado inconstitucional, mas sim que o Registro Torrens obrigatório foi declarado inconstitucional por ter sido instituído por um decreto do Governo Provisório. Assim, os Estados que quisessem poderiam adotar por suas próprias leis o sistema, instituindo, inclusive, sua obrigatoriedade, se assim o desejassem. Tal declaração foi, entretanto, suficiente para colaborar decisivamente para a ruína do projeto político de reforma do Governo Provisório. 


\section{Cap. 7 - Políticas estaduais de terras.}

\subsection{Introdução.}

Tendo atravessado boa parte do séc. XIX, o longo embate entre centralizadores e descentralizadores teve como um de seus pontos fundamentais a Proclamação da República e a decorrente realização da Assembléia Constituinte de 1891. Como visto, no que tange à questão de terras, de enorme importância naquele momento, o resultado desse confronto foi amplamente favorável aos defensores da descentralização.

A passagem da propriedade das terras devolutas aos Estados federados permitiu que cada unidade federativa organizasse e mantivesse da forma que melhor entendesse a sua política de terras. Considerando que a administração das terras, dentro da qual se incluía sua alienação, era considerada matéria de direito administrativo e tendo ainda em vista que a Constituição Federal de 1891 atribuía ampla liberdade aos órgãos federados para que eles organizassem sua administração, pode-se notar que cada Estado passou a ter grande liberdade para dispor sobre suas terras.

\subsection{A manutenção pelos Estados da Lei de Terras de 1850.}

Ao analisar as leis e a política de terras realizadas pelos Estados federados brasileiros no período que sucedeu à promulgação da Constituição Federal, um ponto pode causar certa estranheza. Levando-se em conta a enorme liberdade de que gozavam os Estados federados para tratar de suas terras, como se pode explicar que, na prática e guardadas algumas peculiaridades, houvesse enorme semelhança entre as legislações dos mais diversos Estados brasileiros?

Com efeito, as políticas estaduais de terras aproximam-se em diversos pontos. Acima de tudo, pode-se notar que, de modo geral, os Estados brasileiros, ao se verem atribuídos de legislar sobre suas terras, valeram-se em grande parte da legislação imperial, sobretudo da Lei de Terras de 1850. Mantiveram em suas leis estaduais os princípios básicos e muitas das regras da Lei de 1850, apenas adaptando-as aos novos tempos, adaptação esta que, como veremos, muitas vezes se resumiu à mudança de datas-limites.

Aqui, outra estranheza nos é causada: as forças provinciais locais lutaram durante tanto tempo pelo controle das terras e de sua legislação para, quando finalmente conseguiram exercer tal poder, aplicar o mesmo instrumento legislativo criado e publicado por seus opositores, contra o qual elas mesmas haviam resistido? 
Poder-se-ia esperar que, uma vez vencida a corrente centralizadora e trazidas as terras devolutas ao controle estadual, pelo menos alguns dos Estados federados aproveitassem a oportunidade e se livrassem da Lei de 1850. Como veremos mais adiante, na quase totalidade dos Estados brasileiros isso não ocorreu, acontecendo justamente o contrário, isto é, servindo-se os Estados da Lei de Terras de 1850 como arcabouço para seus sistemas legislativos estaduais de terras. Mas por quê?

Uma boa resposta nos é oferecida por Lígia Maria Osório Silva, em uma das poucas obras que se dedicam a destrinchar profundamente o assunto, A Lei da Terra - Um Estudo sobre a História da Propriedade de Terra no Brasil, em sua terceira parte, focada na terra durante o período da Primeira República.

Segundo a autora, o aproveitamento da Lei de Terras de 1850 pelas legislações estaduais ocorreu, em grande parte, por ainda permanecerem válidas as motivações que levaram à adoção daquela lei.

Uma de suas principais motivações da Lei de Terras ao procurar inibir a efetivação de novas posses era garantir que tanto os imigrantes subsidiados como os escravos libertos fossem impedidos ou ao menos enormemente dificultados de se tornarem proprietários de terras. Assim, tanto os imigrantes ingressados no Brasil após 1854 quanto os escravos libertos depois desta data não poderiam alegar, nem mesmo por meio de títulos falsos, prática comum na época, que sua posse era anterior à da Lei de Terras. Ou seja, com o fim anunciado da propriedade servil, uma vez que o trabalho não poderia mais ser cativo, as classes agrárias dominantes sentiram a necessidade de tornar cativa a terra, na célebre formulação do sociólogo José de Souza Martins, em O cativeiro da terra (1986).

No entanto, a autora reconhece que apenas essa motivação não é suficiente para entender a adoção pelos Estados da Lei de 1850 por duas razões: (i) em muitos Estados, nem a imigração nem a escravidão tiveram um papel importante pelo qual se justificasse a manutenção da lei; e (ii) em segundo lugar, uma razão ainda mais importante, em nenhum dos Estados manteve-se a data-limite de 1854 para a validade e legitimação das posses, sendo essa data-limite freqüente e sucessivamente prorrogada.

Exemplificativamente, no Pará, por meio do decreto $n^{\circ} 410$, de 08 de outubro de 1891, e, posteriormente, do decreto $\mathrm{n}^{\circ} 82$, de 15 de setembro de 1892, o governo estadual legislou quanto à política de terras. Tais decretos tinham como principal característica a 
ampliação da data-limite para as posses legitimáveis. É interessante notar que a partir de 1895 passou a ser praticamente uma rotina anual a expedição de decretos que prorrogassem os prazos para que fossem feitas as legitimações de posse. Com efeito, de 1895 a 1929 foram publicados quase que anualmente decretos nesse sentido.

Também a Bahia, por meio da lei $\mathrm{n}^{\circ}$ 198, de 21 de agosto de 1897, aumentou o período dentro do qual as posses seriam legitimáveis, fixando como data-limite para a legitimação o dia 02 de julho de 1891. Após isso, a partir de 1899, diversas e sucessivas leis prorrogaram o prazo máximo para a realização da legitimação, o qual acabou por se estender até o ano de 1921.

Santa Catarina também não fugiu ao modelo de prorrogação de períodos para a legitimação das posses. Por meio do decreto $\mathrm{n}^{\circ} 70$, de 22 de maio de 1893, o governo estadual legislou sobre as terras, fixando nova data-limite para as posses legitimáveis e prorrogando periodicamente o prazo para essas legitimações até o ano de 1926.

Exemplo semelhante pode ser encontrado no Estado de Minas Gerais, que, por meio do decreto $\mathrm{n}^{\circ} 1.351$, de 11 de janeiro de 1900, modificou não só os prazos para legitimação como também a data-limite para que uma posse fosse considerada legitimável.

Seria exaustivo elencar aqui todas as leis estaduais que atuaram de maneira semelhante. Por ora basta dizer que, mais adiante, ao aprofundarmos a análise com o emblemático caso da legislação de terras do Estado de São Paulo, poderemos entender um pouco melhor como e por que se dava essa prorrogação das datas-limite das posses legitimáveis.

Como se disse, a simples motivação de impedir ou dificultar o acesso à propriedade de terras aos imigrantes subsidiados e aos escravos libertos não é suficiente para entender a manutenção pelos Estados da Lei de Terras de 1850. Qual seria, então, a outra motivação que a essa se somaria?

Um dos principais objetivos da Lei de Terras era a legitimação das posses, transformando simples posseiros (muitas vezes, grandes simples posseiros) em legítimos proprietários. Esse processo de legitimação fazia-se pela via administrativa. Dessa forma, a manutenção da Lei de Terras pelos Estados federados significava, em outras palavras, a manutenção da via administrativa como a via eleita para o processo de legitimação de posses. Com a abolição da escravidão e a conseqüente valorização da propriedade 
imobiliária, esse processo de legitimação de posses passou a ter uma importância ainda maior. E, agora, mantendo-se a atribuição da solução dos casos de legitimação de posses à via administrativa, os processos de legitimação seriam, em última instância, julgados pelos governadores dos Estados. Após percorrer os Serviços de Terras de seu Estado, seguindo o procedimento votado pela Assembléia Legislativa, caberia ao governador do Estado dar a última palavra nas legitimações de posse. Com isso, os chefes dos governos estaduais passariam, dessa forma, a ocupar uma posição central nas questões de terras, que, por si só,

já ocupavam o centro das atenções. Dessa forma, a classe agrária dominante, que possuía, como se sabe, maior poder de pressão sobre os governos locais, não teria nenhum interesse em retirar dos chefes políticos estaduais a atribuição de decidir a legitimação das posses, posicionando-se favoravelmente à manutenção da Lei de Terras de 1850.

\subsection{A regra: o caso do Estado de São Paulo.}

Visto isso, parece ser interesse observar um pouco mais de perto como se deu a dinâmica dos processos de legitimação de posses nos Estados. Tendo em vista a completa impossibilidade de a presente pesquisa analisar, um a um, todos os Estados brasileiros, optamos pela análise um pouco mais detalhada do caso do Estado de São Paulo. Isso por se entender que foi ali, especificamente, que a apropriação ilegítima das terras públicas pelos particulares pôde mais drasticamente ser notada. Basicamente, por duas razões: primeiro, pela exemplar complacência com que a política de terras paulista e a legislação dela decorrente trataram os casos de posses ilegítimas; e, em segundo lugar, pela abundância de relatos históricos e testemunhos que se encontram acerca da ocupação territorial dessa região, dificilmente comparáveis a qualquer outra região brasileira.

Vejamos, então, um pouco da ocupação do território paulista durante a Primeira República.

Quando da promulgação da Constituição de 1891, o Estado de São Paulo contava em seu patrimônio, como terras devolutas, com aproximadamente $2 / 3$ de todo o seu território (SILVA, 1990:363).

Ao analisar a ocupação territorial do Estado de São Paulo em fins do séc. XIX e início do séc. XX, não se pode esquecer o quanto sua economia era fortemente influenciada pela opulência da produção cafeeira. Além disso, não se pode olvidar o caráter eminentemente exportador da cultura cafeeira, o que faz com que ela e, conseqüentemente, 
a velocidade da ocupação territorial paulista estejam intimamente ligadas às condições econômicas mundiais, que determinam a maior ou menor demanda externa pelo café.

Com efeito, pode-se notar que as duas principais intervenções estatais paulistas em matéria de terras, bem como os dois momentos de maior produção legislativa dispondo sobre o tema, coincidem com as duas grandes ondas de expansão cafeeira.

Com a primeira grande expansão da cultura cafeeira, que teve início em 1888 e duraria até 1898, o café, que, nos anos 1860 já havia avançado do Vale do Paraíba sobre uma pequena faixa do Oeste do Estado (região de Campinas), intensificou ainda mais sua marcha, adentrando no interior do Estado, investindo em regiões como Mogiana (região de Ribeirão Preto), Baixa Paulista (região de Araraquara) e, em menor proporção, Alta Sorocabana (região de Botucatu).

O resultado desse avanço da agricultura cafeeira no decênio (1888-1898) foi a criação de 41 novos municípios pelo governo do Estado e a triplicação dos pés de café plantados no período.

Seguiu-se a esse período de expansão do café uma crise de superprodução que intimidou o plantio de cafezais. Assim, entre 1898 e 1909, a produção cafeeira sofreu forte desaceleração. Nesse período, os pés de café cresceram apenas $10 \%$, e nenhum município foi criado no Estado.

Após a Primeira Guerra Mundial, a crise da superprodução do café foi superada, contando para isso com uma forte política estatal de valorização do produto, que acabou por elevar seu preço no mercado internacional.

Assim, entre os anos de 1909 e 1918, a agricultura cafeeira conheceu uma nova onda de expansão, e, em 1918, o número de pés de café plantados havia passado de 1 bilhão. Novamente, o número de municípios criados pelo governo estadual acompanha a expansão cafeeira: entre 1910 e 1919, foram criados 32 municípios.

Já se havia dito que a incisividade das políticas de terras estaduais paulistas correspondia às fases de expansão cafeeira. Agora que foram rapidamente pontuadas as duas grandes ondas de expansão cafeeira, vejamos como a elas corresponderam políticas estaduais de terras que acabariam por se destacar por sua permissividade.

A primeira intervenção do governo estadual na questão das terras ocorreu em 1895. O Congresso do Estado de São Paulo elaborou e aprovou, em 22 de junho daquele 
ano, a lei $\mathrm{n}^{\mathrm{o}} 323$, que disciplinava o tratamento jurídico dispensado às terras devolutas, incluindo sua medição, demarcação e aquisição. Além disso, a lei tratava da legitimação ou revalidação das posses e concessões de terras. A exemplo do que ocorreu nos outros Estados federativos brasileiros, com essa lei também em São Paulo o tratamento jurídico das terras fundamentava-se, essencialmente, nas disposições da Lei de Terras de 1850.

Ocorre que os dispositivos previstos pela lei de junho de 1895 foram considerados excessivamente rigorosos com os possuidores de terras, levantando contra si forte pressão política, almejando sua alteração e substituição por regramentos mais amenos. Dentre todas as regras estabelecidas pela lei, a que maior comoção causou aos possuidores de terras era a que impossibilitava a legitimação de posses realizadas depois do ano de 1854 .

Não se deve pensar, entretanto, que aqueles que pleiteavam regras mais amenas para a validação de suas posses fossem somente os pequenos posseiros espalhados pelo interior do Estado. Grandes interesses avidamente se movimentavam, buscando se apossar das terras com as quais a União havia contemplado os Estados e sobre as quais estes não pareciam efetivamente preocupados em manter o seu poder.

Assim, frente à forte pressão política que atacava a rigorosidade das regras de legitimação de posses da lei de junho de 1895, o Estado de São Paulo promulgaria, em 02 de agosto de 1898, a lei $\mathrm{n}^{\mathrm{o}} 545$, esta sim absolutamente compatível com os interesses particulares de quem visava à apropriação das terras públicas.

Em linhas gerais, tal lei dispunha, primeiramente, dois casos em que a legitimação se daria de maneira automática, prescindindo de qualquer processo de legitimação: (i) as posses com título anterior a 1878; e (ii) as posses em que o particular houvesse, desde 1868, estabelecido moradia habitual e cultura efetiva.

A legitimação das demais posses seria feita por meio de processo de legitimação, e a única limitação temporal que a lei de 1898 impunha era a de que a posse tivesse tido início até a promulgação da lei de 22 de junho de 1895. Ou seja, com a lei de 1898, todas as posses realizadas entre 1854 e 1895, que, até então, não eram legitimáveis, passaram a sê10 .

Dois anos mais tarde, seria publicado o regulamento da lei de agosto de 1898. Dentre as novidades trazidas por esse regulamento, destaca-se como a mais importante a criação do Registro Público das Terras. Este órgão seria responsável pela publicidade da 
propriedade imobiliária das terras do território paulista. Nele deveriam ser efetivados os registros das sentenças de legitimação de posses e de revalidação de sesmarias. Além disso, deveriam também ser registrados os títulos de aquisição de terras devolutas. E, por fim, deveriam ser registradas, pelo Estado, as terras devolutas.

Esta última imposição de registro, o das terras devolutas pertencentes ao Estado (prescrita no par. $1^{\circ}$ do art. 25), é bastante emblemática. Ela demonstra, sem deixar margens a grandes dúvidas, como, na visão dos governantes estaduais paulistas, as terras devolutas deveriam receber tratamento idêntico àquele dispensado às propriedade imobiliárias particulares, sendo regidas pelo direito civil comum e sendo o Estado, enquanto seu proprietário, em nada diferente do particular.

Entretanto, como era de esperar, a obrigação do Estado em registrar suas terras devolutas não foi cumprida, nem mesmo poderia sê-lo, levando-se em conta a enorme dificuldade que encontrava até mesmo em identificar as ditas terras, quanto mais em registrá-las ${ }^{122}$. Pode-se dizer, inclusive, que o Estado paulista nem sequer se esforçou no sentido de registrar suas terras ${ }^{123}$.

Entretanto, embora durante a Primeira República o Estado de São Paulo tenha tratado de maneira tão displicente quanto os demais Estados a questão do registro das terras, nele os particulares parecem ter se preocupado de maneira um pouco mais efetiva em registrar suas terras, estando certamente tal interesse interligado ao surto cafeeiro na região, que valorizou a propriedade de terra e tornou necessária, para assegurá-la, alguma forma de legitimação.

Assim, há relatos históricos de verdadeiras torrentes de proprietários em direção ao Cartório de registros:

“(...) todo mundo afluiu ao Cartório de Hipotecas. Em seis meses, dos livros constava tudo. Depois, o silêncio voltou a pesar por dez anos em cima dessa meia tonelada de papéis sem que sobre estes se

\footnotetext{
122 "Naturalmente, o Estado não cumpriu sua obrigação, pela forte razão de que nem sabia ao certo onde ficavam as suas terras, tendo em vista que as terras devolutas se definiam por exclusão, isto é, partia-se do pressuposto de que terras devolutas eram aquelas que não estavam no domínio particular e estas, também, não estavam cadastradas" (SILVA, 1990:370).

123 "É bem verdade que o estado não demonstrou o mínimo interesse em procurar saber onde estavam localizadas as suas terras".
} 
pronunciassem os funcionários públicos encarregados" (COBRA, 1923:134).

Como se pode ver do próprio relato, se o Registro Público das Terras alcançou relativo sucesso, foi unicamente pelo elevado interesse econômico em jogo nas propriedades imobiliárias das terras, e não por um efetivo interesse estatal em promovê-lo. Tanto foi assim que, uma vez realizado o registro das terras particulares, o Estado mantevese inerte quanto ao que fazer com os dados recolhidos, tornando-os absolutamente inócuos e perdendo uma grande oportunidade de frear os apossamentos ilegais e a invasão que suas terras devolutas vinham sofrendo.

Inclusive, o fato de o governo estadual não ter respeitado a obrigação de registro das terras devolutas por ele mesmo instituída tornou-se um forte e comum argumento dos posseiros nos processos jurídicos pelos quais, depois de 1930, o Estado buscou, sem muito sucesso, reapropriar-se das terras de que havia sido desapossado.

Pode-se dizer que, na verdade, não era somente a inércia do governo estadual paulista que fazia com que ele fechasse os olhos à incisiva invasão sofrida por suas terras. Tratava-se, de certo modo, de uma decisão política, o governo estadual preferia não ver as ilegalidades com que de suas terras ele era espoliado, desde que, em contrapartida, a produção cafeeira crescesse vertiginosamente e ao menos parte do prejuízo infringido contra o patrimônio público estadual retornasse aos cofres em forma de impostos de exportação.

Nesse sentido, novamente um relato de COBRA nos ajuda a chegar a essa conclusão:

"O governo entendeu que era melhor abrir os diques, deixar que todo mundo entrasse pelas terras devolutas, plantando café numa avançada sublime da audácia, recolhendo-se aos cofres públicos, sob a rubrica de impostos de exportação, quantias que compensam, um tanto, a perda de alguns milhões de alqueires que se foram e não voltarão mais" (1923:131). 
Ao contrário do que se possa irrefletidamente pensar, essa postura liberal do poder estadual com suas terras não fez com que o acesso à terra se democratizasse. Apesar da acuidade com que descreve a postura governamental paulista, COBRA parece ter exagerado um pouco ao identificar os beneficiários da liberalidade do governo com suas terras. Não foi "todo mundo" que entrou pelas terras devolutas. A bem da verdade, limitações econômicas e sociais influiriam pesadamente na possibilidade de um particular conquistar seu próprio território, impedindo muitos de poder se aventurar em busca de um pedaço de terra. Assim, a liberalidade estatal em se desfazer de suas terras era levada, pelo contexto político-social, a uma filtragem, ocorrendo uma espécie de seleção, pela qual apenas aqueles que possuíssem bens e prestígio suficientes conseguiriam aumentar suas propriedades imobiliárias, passando então a possuir mais bens e gozar de mais prestígio, o que lhes possibilitava acelerar o crescimento ilegal de suas propriedades. E a negligência com que o poder político estadual se distanciou da resolução dos conflitos locais pela terra apenas agravou as barreiras.

Esse processo se imbrica, em grande parte, com o fenômeno do coronelismo ${ }^{124}$. A ação dos posseiros poderosos tinha o respaldo do poder político local (municipalidades). Isso gerava uma constante insegurança dos posseiros menos influentes quanto à garantia de poderem permanecer nas terras que até então vinham cultivando. Basta ver que os agrimensores eram nomeados pelas autoridades municipais.

O poder estadual mantinha-se distante das disputas locais, negligenciando a garantia da aplicação da lei que havia promulgado e deixando a cargo dos mandos e desmandos municipais a resolução dos conflitos de terra. Tanto a capacidade de se manter nas terras quanto a de legalizar a posse de fato em um direito efetivo não podiam prescindir das influências do poder público municipal, fazendo com que aqueles que não gozassem de prestígio político nem tivessem nada a oferecer em contrapartida (por exemplo, votos de cabresto) não só se mantivessem alijados do processo de ocupação das terras públicas, mas ainda fossem desapossados das poucas terras das quais haviam conseguido se apossar.

Mesmo o Poder Judiciário inseria-se nessa dinâmica de poder, permanecendo em boa parte servil aos chefes políticos. Assim, tornava-se inútil buscar na Justiça o remédio

${ }^{124} \mathrm{O}$ estudo aprofundado do coronelismo ultrapassa em muito os limites aqui pretendidos, de forma que nos dedicarmos demais a esse fenômeno nada seria que não um desvirtuamento da presente pesquisa.

Para uma visão mais profunda e sistemática do coronelismo, LEAL (1997). 
contra a parcialidade dos governantes. Mesmo os juízes de Paz, eleitos que eram, apresentavam-se bastante subservientes aos poderes políticos municipais, pois sabiam que sua eleição e toda sua futura carreira política deles dependiam. Os únicos que, por serem integrantes de carreira própria, poderiam interferir com certo grau de independência no processo de apropriação das terras seriam os juízes de Direito ${ }^{125}$. No entanto, deve-se lembrar que, de acordo com o art. 138 do regulamento de 1900, em regra, não cabia aos juízes de Direito, e sim aos juízes comissários, o julgamento dos processos de discriminação das terras públicas das particulares. Como se sabe, os juízes comissários eram nomeados pelo governador de Estado, e, se o chefe político municipal estivesse alinhado ao governo estadual, como normalmente ocorria, tal nomeação se daria de acordo com a preferência do poder local. Os juízes de Direito apenas seriam chamados a decidir sobre conflito de terras caso aqueles que se sentissem prejudicados a eles recorressem e, ainda assim, somente poderiam se pronunciar sobre a questão da fixação das linhas divisórias das terras.

Com todos esses instrumentos, montou-se um mecanismo em que aqueles que tinham condições econômicas e políticas se apropriavam ilegitimamente das terras públicas, com a certeza de que a inércia e a liberalidade do governo estadual acabariam por promover a expurgação dos vícios jurídicos dessa apropriação indevida, conferindo-lhes mais tarde um título de terras juridicamente irretocável.

Passada a Primeira Guerra Mundial, a produção cafeeira conheceu um novo ciclo expansivo, dessa vez em direção ao extremo Oeste do Estado. Para acompanhar esse novo impulso da economia cafeeira, o governo estadual paulista entendeu necessário intervir novamente na legislação de terras, modificando a lei de 1898 e seu regulamento de 1900. Foi assim que o então governador Washington Luís promulgou, em 27 de dezembro de 1921, a lei no 1844, que viria a ser objeto de regulamentação em agosto de 1922. Tal lei

\footnotetext{
${ }^{125}$ Note-se que, mesmo os juízes de Direito, que, teoricamente, possuíam certa autonomia e independência no desempenho de suas funções, estavam sujeitos às pressões políticas e sociais das autoridades locais. Comentando especificamente sobre a região de Campos Novos, que teve como chefe político local do período de 1889 a 1912 o coronel Francisco Sanches de Figueiredo, COBRA relata a esse respeito:

"Em Campos Novos, nessa época, juízes de Direito não paravam. O primeiro nomeado foi o único que se deu bem no lugar; deixando o cargo, depois de quatro ou cinco anos de exercício, ali ficou advogando e dirigindo agremiação partidária. Os outros, mal tomavam posse, requeriam licença e de licença ficavam indefinidamente, já por falta de conforto no lugar, já por não haver garantias para o livre exercício de seu cargo. Destarte estava quase sempre com a vara o primeiro juiz de Paz da sede da comarca, leigo, eleito pelo partido dominante, a cujo cabeça devia obedecer, seguindo orientação do advogado que ao mesmo tempo presidia o diretório" (1923:166-167).
} 
pretendeu, em suma, legalizar a situação dos posseiros irregulares. Com foco nesse objetivo, ela previu que poderiam ser regularizados os títulos de terra de todos os posseiros que estivessem ocupando suas terras pelo menos um ano antes da entrada em vigor da lei (fins de 1920). Além disso, também estariam habilitados à titulação de suas terras todos aqueles que possuíssem um título, mesmo que ilegítimo, antes da promulgação da lei. Por fim, poderiam tirar títulos de terras todos os que tivessem obtido uma decisão judicial favorável.

A liberalidade da política estadual paulista de terras, que já era patente com a lei de 1898, torna-se, com a lei de dezembro de 1921, absurdamente caricata. Dificilmente se poderia imaginar qualquer posse obtida entre 1895 (último limite temporal para legalização das posses pela lei de 1898) e 1921 que não se enquadrasse em algumas das hipóteses de legitimação previstas pela nova lei.

Essa liberalidade fica ainda mais caracterizada com a autorização da lei de 1921 da concessão gratuita de terras devolutas ${ }^{126}$. Aliás, levando-se em conta que todo o arcabouço da legislação estadual de terras estava fundamentado na Lei de Terras de 1850, não se pode deixar de notar aqui, além de uma incompatibilidade entre a lei de 1921 e a de 1850, um grave retrocesso.

\subsubsection{Jardim das Camélias: a irresolução jurídica como instrumento de} dominação.

Para refletir sobre a política de terras do Estado de São Paulo, parece ser interessante nos remetermos ao trabalho de pesquisa realizado por James Holston, originalmente intitulado The Misrule of Law: Land and Usurpation in Brazil, sendo traduzido posteriormente como Legalizando o Ilegal: Propriedade e Usurpação no Brasil.

A pesquisa de Holston gira em torno de uma questão inicial: como se pode entender o direito se o sistema jurídico que, por princípio, deveria objetivar resolver conflitos mostra-se como "um meio de perpetuar e obscurecer as disputas ao invés de resolvê-las?" (HOLSTON, 1993:68).O autor faz uma análise histórica do tratamento legal dispensado à propriedade de terra. Chama a atenção a metodologia empregada por Holston,

${ }^{126}$ Cf. com o art. $2^{\circ}$ do Regulamento para a Execução da Lei no 1.884 :

“Art. $2^{\circ}$. Fica o governo autorizado a alienar gratuitamente as terras devolutas de que trata o artigo antecedente a nacionais ou estrangeiros que as cultivem". 
que, para tal análise, foca-se em um caso específico que o permite reconstruir boa parte da história da propriedade imóvel brasileira.

O caso tratado por Holston é o da propriedade de terra no Jardim das Camélias, região periférica da cidade de São Paulo, localizada às margens do Rio Tietê. A história dessa região é tão complexa que mesmo Holston, que passou dois anos (entre 1987 e 1990) debruçado sobre ela, admite que "frente à sua complexidade sem limites, não posso afirmar que o entendo por inteiro, tampouco seria prudente dirimir de erros e distorções a análise de seus contornos" expostos (HOLSTON, 1993:84).

A história da reivindicação dessas terras remonta a 1580, ano em que foi estabelecida uma concessão de terra real para o antigo aldeamento indígena de São Miguel e Guarulhos, o qual viria a ser oficialmente extinto em 1850. Assim, por ser esta a origem mais remota da propriedade da terra da região, surge um primeiro ator a reivindicar essa propriedade: o governo federal. Esse pedido se basearia no fato de que a Lei de Terras imperial de 1850 e a legislação que a seguiu teriam incorporado os aldeamentos indígenas ao patrimônio nacional.

No entanto, para o autor, o "centro nevrálgico" da questão ocorreria em outro momento da história de nosso país, sendo este o ponto em que o trabalho de Holston mais de perto interessa à presente pesquisa. Como já se viu, a Lei de Terras utilizava a promessa de aquisição de terras públicas para atrair imigrantes europeus para o Brasil, de início como trabalhadores substitutos do trabalho escravo e, depois, como colonos livres proprietários de suas terras. Seguindo essa mesma lógica, o primeiro governo da República recémproclamada fez concessões a particulares para que estes promovessem em terras devolutas a fundação de colônias agrícolas de imigrantes. Trata-se, como visto no item 3.3.1, dos burgos agrícolas.

É nesse contexto que, em 1890, foram concedidos ao engenheiro Ricardo Medina 50 mil hectares de terras devolutas. O contrato de concessão tinha diversas condições, dentre as quais (i) a fundação em dois anos da colônia agrícola, (ii) a realização de um levantamento distinguindo as áreas devolutas daquelas já adquiridas por outros e (iii) o pagamento ao governo de um preço fixo para cada área vendida aos imigrantes.

Apesar de estar previsto que qualquer não cumprimento dessas condições rescindiria o contrato, havia a previsão de que, mesmo não cumprindo com a sua parte, o 
cessionário ficaria com metade das terras cedidas, sendo a outra metade restituída ao governo.

Em 1891, Medina transferiu a concessão, com todas as suas condições, para o Banco Evolucionista. Este banco, cujo fundador era o próprio Medina, era um dos muitos bancos de empreendimentos imobiliários que se criaram visando aproveitar a nova política de terras. Transferida a concessão, o banco foi incapaz de realizar a colonização das áreas no tempo exigido, sendo rescindido o contrato. No entanto, o banco ofereceu uma proposta de pagamento das áreas mais ao sul da área concedida, proposta que foi aceita pelo governo republicano, que, em 1892, concedeu ao banco o título de 25 mil hectares. Note-se, entretanto, que o Banco Evolucionista espertamente não realizou a discriminação das terras devolutas dessa região daquelas que não o eram. Ainda assim, foram-lhe concedidos os 25 mil hectares, os quais, é bom lembrar, continuavam condicionados às exigências do contrato de concessão.

Um ano mais tarde, o Banco Evolucionista hipotecou esse título condicional ao Banco de Crédito Real do Brasil, que acabou por ficar definitivamente com o título em virtude da falência daquele em 1900. Nove anos depois, seria o Banco de Crédito Real do Brasil que faliria. No entanto, durante a liquidação do banco, seu presidente, Eugênio Hanold, compraria o título das terras do Jardim das Camélias, vendendo-o em 1917 para uma companhia imobiliária chamada Predial. Ocorre que, entre a aquisição e a venda do titulo, diversos credores do Banco Evolucionista entraram com processos pedindo a parte da propriedade que a eles caberia. O Estado de São Paulo, por sua vez, com base no art. 64 da Constituição de 1891, alegava que ele detinha as terras devolutas em questão. Submetido o caso ao Supremo Tribunal Federal, este o decide em 1928. Segundo Holston, tal decisão "mais pareceu complicar do que resolver a disputa" (Holston, 1993:85), reafirmando a validade dos direitos do Banco Evolucionista, por negar que a Constituição os tenha esvaziado, estabelecendo, no entanto, que, com base na cláusula de reaquisição constante do contrato inicial de 1890, o Estado de São Paulo detinha metade dos direitos sobre os 25 mil hectares, definindo, portanto, o Estado, e não a União, como beneficiário da cláusula.

A história continua com mais transferências realizadas sobre títulos de propriedade cujas origens são, quando pouco, duvidosas. No entanto, pelo muito que já foi dito - pouco comparado à complexidade do caso -, acredito que já se possa vislumbrar a linha da 
pesquisa de Holston. Reconstruindo essa confusa história legal, o autor mostra como, por trás das irresoluções cuidadosamente orquestradas, as leis de terras incentivaram os conflitos a respeito delas. "No decorrer deste processo, práticas ilegais produzem leis, soluções extralegais são incorporadas no processo judicial e a lei é confirmada como um canal de desordem estratégica". Para o autor, é assim, por meio da desordem estratégica, que a lei assegura a manutenção dos privilégios daqueles que possuem poderes extralegais de manipulação da política, da burocracia, enfim, da própria história. Por fim, diga-se, a irresolução jurídica acaba por se mostrar, em especial no caso de terras brasileiro, como um "meio de dominação efetivo, embora perverso" (Holston, 1993:87).

\subsection{A exceção: o caso do Estado do Rio Grande do Sul.}

Como vimos, a liberalidade com que o Estado de São Paulo tratou a legitimação das posses ilegais de suas terras devolutas durante a Primeira República, antes de se constituir em exceção, emblema uma verdadeira regra verificada na quase totalidade dos Estados federados. Não é gratuito, entretanto, o cuidado de usar a ressalva "quase", pois nem todos os Estados atuaram dessa forma. A eloqüente exceção trata-se do Estado do Rio Grande do Sul.

Ao tratarmos do Rio Grande do Sul, embora não seja especificamente o tema da presente pesquisa, não pode ser ignorada a forte divergência existente entre os pensadores que cuidaram da Primeira República sul-rio-grandense. De um lado, a maior parte dos pensadores da historiografia tradicional entende que, devido às especificidades da transição republicana naquele Estado da Federação, não se poderia ali observar o fenômeno do coronelismo tal como encontrado nos demais Estados ou que, ainda segundo essa primeira corrente, quando muito, no Rio Grande do Sul se encontraria apenas uma versão atenuada, amenizada do fenômeno coronelista nas relações entre poderes locais e estaduais, perdendo ali o coronelismo muito de sua força enquanto esquema explicativo. De outro lado, embora em número menor, há um crescente número de pensadores que procuram diminuir a relevância que a historiografia tradicional conferiu às especificidades do processo republicano gaúcho, entendendo que no Rio Grande do Sul, como em qualquer outro Estado brasileiro, o fenômeno coronelista se fez notar.

Embora reconhecendo a discussão acima como um ponto nodal para entender a Primeira República gaúcha e, conseqüentemente, a Primeira República brasileira, não se 
pretende neste trabalho o aprofundamento na questão. E isso por uma razão muito simples. Para os fins aqui pretendidos, podemos nos valer de um núcleo comum aos pensadores de ambas as correntes, um núcleo que, a nosso ver, estaria fora de disputa.

Com efeito, embora discordem das conseqüências, pensadores de ambos os lados parecem concordar que no Rio Grande do Sul houve uma confluência de circunstâncias políticas, econômicas e sociais específicas que, independentemente de terem ou não inibido o fenômeno coronelista, influenciaram a transição republicana gaúcha.

Vejamos, então, de forma breve, quais seriam essas circunstâncias.

Na passagem da Monarquia para a República, ocorreu no Rio Grande do Sul um processo inédito no Brasil naquele momento histórico: em vez do continuísmo do comando do poder local nas mãos da oligarquia latifundiária, houve uma alteração na forma de dominação e um novo grupo se instalou no poder. Tal ineditismo deveu-se a diversos fatores, dentre os quais os principais foram o descontentamento das classes emergentes e o enfraquecimento e a divisão das classes dominantes.

Quando da Proclamação da República, o Rio Grande do Sul possuía, ao contrário da grande maioria dos Estados, inúmeros grupos sociais que, a despeito da prosperidade econômica que vivenciavam, mantinham-se excluídos do poder político, e o Estado patrimonialista, dominado que era pela oligarquia pecuarista, privilegiava a economia pecuário-exportadora. $\mathrm{O}$ descontentamento desses novos grupos sociais crescia e eles se mostravam suscetíveis a serem capturados por partidos com novas orientações políticas.

Ao final do Império, a sociedade tradicional gaúcha encontrava-se abalada. A esse abalo ainda se somou uma longa crise econômica, de quase dez anos de duração, que dividiu a classe regional dominante em dois grupos, contrapondo os charqueadores de Pelotas aos pecuaristas do Sudoeste.

Enfim, foi a instabilidade gerada pelo descontentamento das classes emergentes e pelo enfraquecimento e divisão das classes dominantes que abriu portas a um processo de modificação e, por que não dizer, modernização do Estado. Foi nesse contexto que, com o apoio do governo central, foi possível aos positivistas do Partido Republicano Riograndense (PRR) chegar ao poder. No entanto, deve-se notar que os conflitos pelo poder se mantiveram, e os setores oligárquicos continuavam sequiosos de retomar o poder perdido, tanto que, em 1893, tais conflitos dariam causa à Revolução Federalista. 
A notícia da Proclamação da República chegou ao Rio Grande do Sul por meio de um telegrama de Quintino Bocaiúva à Redação do jornal A Federação, órgão propagandista fundado em 1884 pelo incipiente Partido Republicano Rio-grandense (PRR). Teve início a partir de então um período de profunda instabilidade institucional e política expresso no sobe e desce de governadores e na derrubada de funcionários públicos de seus postos. $\mathrm{O}$ PRR, mesmo engrossado por adesistas oportunistas, continuava minoritário e tinha dificuldades de impor seu domínio político ao Estado. No interior do partido, Júlio de Castilhos afirmou-se progressivamente como liderança, precipitando dissidências. Nesse processo de construção de um novo pólo de poder, Castilhos contou com o inestimável apoio, sobretudo, dos governos Marechal Deodoro da Fonseca e Floriano Peixoto, da oligarquia cafeeira paulista, do Exército Nacional, dos positivistas religiosos, dos grandes comerciantes e financistas urbanos sul-rio-grandenses, especialmente de Porto Alegre, Pelotas e Rio Grande, entre outros (AXT, 2001a).

Entretanto, não se pode deixar de notar que boa parte dos pecuaristas e dos comerciantes da região da fronteira, que dominaram isoladamente a política regional durante o Império, embora continuassem de certa forma integrando o conjunto da classe dominante, foram deslocados para uma posição secundária na definição das políticas públicas. Isso é admitido até mesmo por Gunter Axt, um dos principais expoentes e defensores da tese da efetiva existência de um coronelismo gaúcho. E é justamente nessa relegação da classe agrário-latifundiária a segundo plano que se encontra uma das principais especificidades do processo de transição republicana gaúcha.

Cabe aqui um rápido retrato da sociedade e da estrutura fundiária gaúcha de então. Quando comparada às demais sociedades regionais brasileiras, a sociedade gaúcha de fins do Império não somente possuía mais setores mercantis que realizavam trocas mútuas como também era socialmente mais diversificada que as demais. $\mathrm{E}$ isso mesmo quando comparada a São Paulo, pois, enquanto a região paulista de agricultura de exportação possuía basicamente o setor exportador e, quando muito, um outro setor muito pouco mercantilizado, o Rio Grande do Sul possuía ao menos três setores econômicos que mantinham entre si relações comerciais: o da pecuária de exportação, o charqueador e o da agricultura e do artesanato das colônias de povoamento. Aliás, outro fator diferencial da sociedade gaúcha é a existência, ao lado das classes proprietárias tradicionais, de uma 
classe média rural concentrada nas colônias de povoamento, além de classes urbanas das vilas e cidades da zona colonial.

Enfim, foi esse hiato de poder político, gerado simultaneamente pela instabilidade causada pelo descontentamento das classes emergentes e pelo enfraquecimento e divisão das classes dominantes, que possibilitou a ascensão do PRR, na pessoa de Júlio de Castilhos. E, o mais importante, ao alijar boa parte da classe de proprietários agráriolatifundiários do poder político por ela historicamente exercido durante o Império, a ascensão de Júlio de Castilhos ao poder estadual se deu sem compromissos políticos com a classe agrário-exportadora latifundiária. Aliás, pelo contrário, se deu justamente com a assunção de compromissos frente às demais classes sociais que, em muitos pontos, se contrapunham aos interesses da classe latifundiária.

Foi nesse contexto que, no dia 25 de junho de 1891, foi instalada a Assembléia Constituinte em Porto Alegre que daria origem à primeira Constituição gaúcha. Conforme relata AXT (2001a), os 43 deputados pertenciam todos à chapa republicana, que fora consagrada no pleito desferido em 5 de maio. Isso porque o decreto federal $\mathrm{n}^{\circ} 511$, conhecido como Regimento Alvim, estabelecia que as eleições daqueles tempos, mesmo para o Legislativo, eram "tudo ou nada", se realizando por maioria relativa, em lista completa, o que liquidava as chances de representação das minorias ou dissidências. Assim, com a exclusão formal da oposição, o PRR legislava sozinho. Ou, mais que isso, constituía sozinho o Estado do Rio Grande do Sul.

Os trabalhos constituintes foram céleres. Como era de esperar, dada a composição da Assembléia Constituinte, o consenso foi praticamente a regra. Do projeto original, elaborado exclusivamente por Júlio de Castilhos, derrubaram-se fundamentalmente apenas a investidura eletiva dos juízes distritais e a extinção do júri, indicando uma pequena reação da magistratura togada ao constitucionalismo castilhista. No dia 14 de julho, a Constituição foi promulgada, Castilhos foi indiretamente eleito Presidente do Estado, e a Constituinte, convertida em Assembléia ordinária.

Muitos foram os pontos polêmicos dessa Carta, com destaque para os mecanismos de intervenção do poder estadual nos municípios, para a elisão do conceito liberal de separação dos poderes e para a possibilidade de reeleição indefinida do primeiro mandatário do governo estadual e dos chefes dos Executivos municipais. Enfim, tratava-se 
de uma Constituição inegavelmente autoritária, sendo, inclusive, a discussão da compatibilidade entre ela e a Constituição Federal discutida no Congresso Nacional até o ano de 1923.

Entrando já especificamente no tema da política de terras, tem-se que, dentre as características autoritárias da Constituição estadual, observa-se em seu artigo $20, n^{\circ} 21$, que ela estabeleceu como atribuição do Presidente de Estado "organizar e dirigir o serviço relativo às terras do Estado (...)”. Já aqui se nota uma peculiaridade no direito de terras do Estado sul-rio-grandense com relação aos demais. Trata-se da única Constituição estadual de todo o país que não atribui tal poder à Assembléia Legislativa.

Como se pode ver, também em relação à política de terras, a Constituição estadual gaúcha não tem como escapar da crítica de autoritária, não só pela atribuição ao chefe do Executivo de legislar sobre as terras públicas, mas também pela própria composição da Assembléia Constituinte, posteriormente Assembléia Legislativa, que quase nenhuma oposição enfrentava em sua tarefa de legislar.

Deixando de lado, ao menos na parte em que isso for possível, o reprovável autoritarismo do processo legislativo gaúcho, o fato é que no Estado do Rio Grande do Sul pôde se notar uma preocupação governamental em registrar e cadastrar as terras particulares, discriminando-as das terras públicas e diminuindo, com isso, as fraudes e usurpações que se intentavam contra as terras estatais.

Indício de tal preocupação é a constância da abordagem da questão de terras nas mensagens do Presidente do Estado à Assembléia dos Representantes.

$\mathrm{Na}$ Mensagem à Assembléia dos Representantes de 20 de setembro de 1896, por exemplo, Júlio de Castilhos, então Presidente do Estado, alertou para as fraudes de legitimação de posses ocorridas no regime anterior e comparou os números de seu governo aos daquele:

"Para formardes um juízo aproximado das fraudes a que estiveram expostas as terras públicas no antigo regime, basta-me indicar-vos que em 1881, durante os 28 anos decorridos após o regulamento de 30 de janeiro de 1854, tinham sido ainda legitimadas posses de cerca de 50 léguas quadradas: De setembro a 15 de novembro de 
1889, ficou também facilmente legitimada a área de 70 1/2 léguas quadradas, além de 200 milhões de metros quadrados que receberam a indevida legitimação, de julho de 1883 a setembro de 1885. Em contraste, informo que de janeiro de 1893 até o presente momento, isto é, desde que assumi o governo do Estado, a legitimação de posses não foi além de 3,4 léguas quadradas" (Mensagem à Assembléia dos Representantes de 20 de setembro de 1896).

Os processos de legitimação, que eram, em última instância, submetidos à decisão do Presidente do Estado, também eram tratados com severidade, conforme informa também Júlio de Castilhos, na Mensagem à Assembléia dos Representantes do ano seguinte, publicada no ano seguinte, em 20 de setembro de 1897 :

"Têm sido raras as legitimações de posses particulares, em
acentuado contraste com a sua freqüência de outrora, o que é
devido principalmente a invariável serenidade com que são
examinados os processos de medições submetidos à decisão
presidencial. De julho de 1896 até agora foram favoravelmente
julgadas apenas duas legitimações" (Mensagem à Assembléia dos
Representantes de 20 de setembro de 1897).

Tendo em conta as fraudes ocorridas no passado e constantemente denunciadas pelo Presidente de Estado em suas Mensagens, ainda no ano de 1897 o governo estadual buscou promover uma espécie de revisão na legitimação das posses fraudulentas e, ainda, discriminar as terras públicas das privadas. Para tanto, foram criadas comissões técnicas incumbidas de discriminar terras devolutas das particulares, bem como de verificar as posses fraudulentas legitimadas e aquelas cujos títulos estivessem em desacordo com as terras ocupadas. Tais comissões funcionariam até o ano de 1904.

Vale lembrar que, até o momento de criação dessas comissões, o Estado do Rio Grande do Sul adotava ainda as disposições da Lei de Terras de 1850 e seu regulamento de 
1854, visto que ainda não havia sido publicada qualquer lei estadual específica tratando do assunto. Tal situação durou até 05 de outubro de 1899, quando foi publicada a lei $\mathrm{n}^{\circ} 28$, que dispunha sobre o serviço de terras públicas do Estado.

A respeito da necessidade dessa lei, adaptando a Lei de Terras de 1850, disse Joaquim Luís Osório, em sua obra Constituição Política do Estado do Rio Grande do Sul, que mais tarde ficaria conhecida como uma das principais obras do castilhismo:

"Essa lei [a Lei de Terras de 1850], complementada pelo Decreto de 30 de janeiro de 1854, obedeceu ao influxo da época em que foi elaborada, correspondendo às necessidades e refletindo as preocupações de então. Judiciosa e previdente em muitos dos seus enunciados, teria ela realizado integralmente os sãos institutos que a inspiraram, se não houvesse sido sofismada ou deturpada na sua aplicação, através de sucessivos decênios, pelos agentes provinciais do governos imperial, com fácil aquiescência deste. A Lei atual do Estado [Lei ${ }^{\circ} 28$ de 1899], respeitando os princípios fundamentais da Lei de 1850 e os direitos nela amparados, veio simplificar consideravelmente a legislação que rege a matéria, pôr termo à confusão ou incertezas que porventura ainda perdurem e tornar efetiva e eqüitativa a promessa do art. $20, \mathrm{n}^{\circ} 21$, da Constituição do estado, além de coibir de vez as artificiosas tentativas de usurpações fraudulentas" (OSÓRIO, 1982:134-135)

Note-se que, como nos demais Estados federados, também ali a Lei de Terras de 1850 permaneceu em vigor, como arcabouço, no que não contrastasse com a lei estadual. Porém, inegavelmente no Estado sul-rio-grandense as modificações estaduais à Lei de 1850 foram maiores que nos demais Estados.

Dentre outras disposições, a lei de 1898 definia o conceito de terras públicas devolutas como aquelas que não são nem de uso público, nem foram apropriadas por título legítimo. Protegia a posse de boa-fé, o que tranqüilizava os terceiros adquirentes. Fixava um prazo irrevogável de dois anos para a entrada de pedidos de legitimação, evitando, 
assim, qualquer reivindicação posterior oriunda da especulação, e isso traz sossego aos colonos que haviam comprado terras a particulares. Limitava a superfície legitimável a 25 hectares em zona de floresta e a 50 hectares em zona de campo; indicava as regras gerais de cadastro e de venda das terras, cujas modalidades pormenorizadas viriam a constar do Regulamento de 1900, que mostra como a questão das terras estava intimamente ligada à da colonização (ROCHE, 1969: 119-120).

Além disso, a lei estadual ampliou a proteção das florestas contra a devastação e organizou o primeiro código florestal do Rio Grande do Sul, estabelecendo, ainda, algumas normas que seriam importantes na defesa dos direitos territoriais indígenas ${ }^{127}$.

Entre tudo isso, duas são as características que seriam decisivas na seriedade com que o Estado continuaria a tratar a questão das terras devolutas, tornando essa lei especial em relação às demais leis dos demais Estados.

A primeira, a adoção do Registro Torrens como o meio de titulação da propriedade de terras. A outra, a fixação de uma inalterável data-limite para o início das posses que se pretendiam legitimar, além do estabelecimento de um prazo dentro do qual haveria de ser requerida essa legitimação, também improrrogável.

Quanto à segunda peculiaridade, a improrrogabilidade tanto da data-limite das posses legitimáveis quanto de seu prazo de legitimação, ela se refere mais à política estadual legislativa de terras posterior à lei $\mathrm{n}^{\mathrm{o}} 28$ de 1898 do que propriamente a ela. Isso porque, como vimos, as leis estaduais dos demais Estados também pretendiam, ao menos aparentemente, que suas datas-limites e seus prazos para pedido de legitimação fossem improrrogáveis, mas, no entanto, sempre eram sucedidas por leis que prorrogavam os prazos e alteravam as datas-limites, tornando-as letras mortas.

\footnotetext{
${ }^{127}$ O decreto federal $n^{\circ} 8.072$ de 1910 criou o Serviço de Proteção ao Índio, determinando ser da competência desse órgão federal a demarcação das áreas indígenas no Estado.

Atento às perseguições sofridas pelos nativos, o Estado do Rio Grande do Sul, mesmo não tendo essa atribuição legal, propôs-se a auxiliar o trabalho desenvolvido pela União, demarcando várias dessas áreas, as quais passaram a se chamar "toldos", comprometendo-se a garantir às populações indígenas a posse de suas terras, bem como reassentar os invasores.

Criou-se, então, um projeto, que teve amparo na lei no 28 de 1899 e seu posterior regulamento. Em tal projeto, o trabalho de demarcação ficaria a cargo da Secretaria de Estado dos Negócios das Obras Públicas (SENOP), a qual delegou a tarefa à Diretoria de Terras e Colonização - DTC.

(Informações extraídas do Parecer Jurídico elaborado pelo Grupo Técnico, criado pela Portaria $n^{\circ} 352$ de 18.04.95, expedida pela FUNAI, com vistas à regularização fundiária das terras indígenas de Ventara e Caseros).
} 
No Rio Grande do Sul, entretanto, tal não ocorreu. Com efeito, a legislação estadual posterior nenhuma vez sequer renovou a data-limite para a legitimação da posse, constituindo louvável exceção à regra dos outros Estados, pela qual bastava arranjar um modo de se apropriar ilegalmente de terras públicas que o Estado acharia, posteriormente, uma forma de legitimar essa posse.

Para ilustrar a maneira como atuou o Estado do Rio Grande do Sul na questão das terras devolutas, bem como a íntima ligação entre essa atuação e a colonização do território sul-rio-grandense, recorreremos a um breve relato do caso descrito por Rosane Marcia Neumann em seu artigo A colonização do Planalto gaúcho por empresas privadas (2006).

Segundo a autora, preocupado com a violência nas disputas pela posse de terras e com o aumento da demanda por alimentos devido ao crescimento urbano ${ }^{128}$, o governo do Estado do Rio Grande do Sul passou a efetuar um levantamento detalhado das terras devolutas existentes, bem como colher informações sobre as possibilidades de exploração econômica delas, pensando em sua comercialização.

A primeira colônia de imigrantes foi estabelecida pelo governo em 1890, no interior de Cruz Alta. Tratava-se de Ijuí, formada por imigrantes de diferentes etnias, circunstância que privilegiaria a imigração espontânea, isto é, as companhias estrangeiras e aqueles particulares que, com seus próprios capitais, pudessem contribuir para o desenvolvimento da região.

Na compra e venda de terras, destacou-se a Empresa de Colonização Dr. Herrmann Meyer, de propriedade do editor alemão Herrmann Meyer, estabelecida na região Noroeste da Província, com a finalidade de estabelecer colônias privadas voltadas para a produção agrícola. A empresa efetivou as primeiras aquisições de terras a partir de 1897, nas circunscrições de Cruz Alta, Palmeira e Passo Fundo, formando as colônias NeuWürttemberg, Xingu, Boi Preto, Fortaleza, Erval Seco e Júlio de Castilhos.

\footnotetext{
${ }^{128}$ Com relação ao aumento da demanda por alimentos, nota-se, na parte abaixo transcrita de um documento da Câmara Municipal de Cruz Alta respondendo a um questionário do Ministério do Império, datado de 1868, que, desde de o Império, essa já era uma preocupação governamental gaúcha e, desde aquela época, o estabelecimento de colônias era tido como uma solução:

"A pouca população d'este município, em relação ao seu vasto território, se ocupa especialmente, ou no fabrico de erva-mate, ou no comércio das bestas: ambos estes ramos nos últimos tempos tem florescido em demasia, oferecendo uma perspectiva de lucros quase certos, d'aqui provem a falta de estabelecimentos agrícolas no município, e consequentemente a de produção suficiente para o seu consumo, de gêneros alimentícios de primeira necessidade, como sejam o milho, feijão e mandioca. O estabelecimento de algumas colônias nas margens do Uruguai, nas do Ijuí Grande, acima de Santo Ângelo, e mesmo nas Serras do Padilha e dos Jacuí aliviarão estes inconvenientes".
} 
A empresa comprou a maior parcela de terras de particulares, variando a extensão das áreas de 610 a 3.000 hectares, bem como os valores pagos. As primeiras dez posses adquiridas até 1900 perfaziam em torno de 13.465 hectares, cerca de 538 lotes coloniais de 25 hectares. Os proprietários que venderam essas terras contavam com o título de legitimação recente, com datas entre 1878 e 1892, embora residissem na área havia mais tempo.

Cruz Alta, devido a sua extensão territorial, era permeada por vastas zonas de campo e outras de mata. Os estancieiros venderam para a Colonizadora as áreas de mata, as quais não utilizavam para a pecuária. A limitação tecnológica franqueava o estabelecimento de trabalhadores nacionais ou posseiros no interior das matas, voltados para o cultivo de uma pequena lavoura de subsistência e a extração de erva-mate.

A inserção da Empresa de Colonização Meyer, como um empreendimento de caráter capitalista, no comércio de terras de Cruz Alta, gerou conflitos. O trabalhador nacional, instalado até então nas zonas de mata, tolerado dentro de uma rede de relações de poder pessoal e local, foi obrigado a deixar o seu rancho ${ }^{129}$.

Essa situação acabou por provocar uma investigação por parte da Comissão de Verificação de Posses e de Discriminação de Terras Públicas, informando do caso o governo provincial, em 11 de fevereiro de 1900, nos seguintes termos:

"Em resposta a vosso telegrama de 27 de janeiro p. findo, cumpreme levar ao vosso conhecimento que não consta que estejam se fazendo derrubadas de matos do Estado na zona da estrada de ferro, cuja concessão foi passada ao Dr. Herrmann Meyer. Há cerca de dois meses Carlos Dhein, representante do Dr. Meyer, anunciou

\footnotetext{
${ }^{129}$ Em 1899, Carlos Dhein, procurador e sócio de Meyer, mandou publicar uma nota no jornal Cruz Alta, nesses termos:

"Aos interessados e residentes no $4^{\circ}$ distrito. $\mathrm{O}$ abaixo assinado a fim de evitar qualquer desavença e para que não se chamem à ignorância, previne e declara a todos os seus confinantes, proprietários e agregados das posses da Serra do $4^{\circ}$ distrito deste município, que por compra a diversos fez aquisição, cujos posses está dividindo em colônias e derrubando matos para grandes plantações, para que até o fim do mês de Dezembro futuro façam retirar todos os gados de sua criação e costeio; e os que não fizeram dentro do referido prazo, ficarão sujeitos verem ditos animais serem remetidos à Intendência municipal para serem arrematados em, hasta pública, conforme a lei.

Aos mesmos Snrs. que em ditas posses que já tenhão feito suas plantações, será-lhes concedido o direito da colheita e os que o fizeram sem sua concessão perderão o direito às referidas colheitas.

E para que chegue ao conhecimento de todos, mandei publicar o presente pela imprensa.

Cruz Alta, 25 de Novembro de 1899. Carlos Dhein”.
} 
pelo jornal 'Cruz Alta' que tendo adquirido por compra diversas posses, ia mandar dividi-las em colônias e derrubar matos para grandes plantações. Em 13 de dezembro p. findo intimei Carlos Dhein a apresentar no prazo de 8 dias os documentos que provassem seu direito a tais posses. Dentro do prazo marcado me foram apresentados os documentos que constavam de 10 títulos de posses legitimadas e dos translados das escrituras de compra e venda d'essas posses. Aguardava oportunidade para fazer seguir 2 auxiliares afim de verificarem a área e o mais que ocorresse relativamente às referidas posses. Porém acabo de saber que Carlos Dhein requereu mandado de despejo e a força foram retirados d'essas terras, diversos posseiros alguns dos quais, com posses de mais de 30 anos. Resolvi fazer seguir amanhã o auxiliar Carlos Gaertner e um ajudante de corda afim de proceder à averiguação. Ajunto remeto-vos o anúncio de Carlos Dhein no jornal "Cruz Alta" a cópia da intimação que fiz e uma cópia da relação que organizei dos 10 títulos que foram apresentados. Saúde e Fraternidade. Augusto Pestana" (apud NEUMANN, 2006:05).

Meyer tinha como projeto a formação de colônias com imigrantes alemães e de religião protestante, limitando a entrada dos que não se enquadravam nesse modelo. Inicialmente, a maioria dos colonos era originária da zona de colonização antiga do Rio Grande do Sul e, posteriormente, de diversas regiões da Alemanha. O número de colonos de ofício era considerável, propiciando um rápido crescimento da área urbana, com o estabelecimento de pequenas fábricas artesanais.

Em novembro de 1898, Herrmann Meyer, após visitar as várias áreas de colonização do Rio Grande do Sul, realizou uma breve visita às suas colônias. Sua avaliação sobre Neu-Württemberg foi registrada nesses termos:

"Todo este terreno é sumamente valioso para a colonização, porque o acesso é relativamente fácil e os produtos encontram colocação 
vantajosa em Cruz Alta. Há ainda a linha férrea que oferece grandes possibilidades para a exportação.

Atravessamos a região em todos os sentidos, dentro, naturalmente, dos limites que nos ofereciam os trilhos estreitos. Penetramos nos soberbos matos, abrimos clareiras nas elevações para podermos apreciar o panorama todo; descemos aos rios, onde, em mente, já via surgir moinhos, curtumes e, o que em colônia alguma deve faltar, cervejarias, enquanto a fantasia me fazia ouvir do alto da colina mais próxima o tanger dos sinos da igreja, em torno da qual artífices e comerciantes construíam as suas casas (MEYER apud FAUSEL, 1949, p. 7-8).

No ato da compra, o interessado assinava um contrato de compra e venda com a Empresa de Colonização, seguindo os parâmetros da legislação em vigor, recebendo a escritura apenas após a quitação do pagamento.

A empresa anunciava oferecer uma infra-estrutura privilegiada para o estabelecimento do colono, como terras demarcadas, estradas, igreja, escola, proximidade da viação férrea, mercado consumidor e matas riquíssimas com madeiras valiosas ${ }^{130}$, que agregavam valor às terras. O preço do lote em Neu-Württemberg oscilava entre oitocentos mil réis no ano de 1900 e um conto de réis em 1901. Em 1912, uma colônia já valia entre 2 e 3,5 contos de réis.

Em várias oportunidades, a Empresa dirigira-se diretamente ao governo provincial, solicitando a compra de terras devolutas. Em 7 de março de 1904, respondendo pela

\footnotetext{
${ }^{130}$ Apesar de anunciar as madeiras das matas como um agregado ao valor das terras, no contrato de compra e venda, como uma forma de salvaguardar o valor de mercado do lote, estabelecia-se que, enquanto o comprador não pagasse o lote, obriga-se ele a não tirar das matas que tiver encontrado no seu lote senão as madeiras e a lenha estritamente necessárias para as suas próprias construções, uso de casa, utensílios, móveis etc. Outrossim recomenda o vendedor que os colonos em próprio interesse poupem as matas existentes o mais que possível e se declara sempre pronto a ajudar a quem por plantações queira aumentá-las.

Além disso, com receio de que os colonos abandonassem a agricultura e se dedicassem à exploração da madeira, tanto o Estado quanto a Colonizadora procuravam evitar a instalação de madeireiras e serrarias voltadas para a comercialização da madeira. Assim, faziam valer a legislação estadual de 1899, concernente ao regime das colônias no Estado, que estabelecia nos artigos 111 a 113 que as matas existentes nos lotes só poderiam ser derrubadas uma vez, na extensão necessária para o estabelecimento e na extensão necessária para as plantações. Aquele que devastasse área superior ao permitido estaria sujeito ao pagamento de multa de acordo com a infração. A segunda derrubada só era permitida cinco anos após a primeira, indicando a rotação de terras.
} 
Empresa de Colonização, Alfred Bornmueller dirigia um ofício para Augusto Pestana, responsável pela Comissão de Terras e Colonização, em Ijuí, nos seguintes termos:

"Rogamos a fineza de informar-nos, si existem terras devolutas, junto ao território da colônia Neu Württemberg, do lado de oeste a noroeste, ao logo dos rios Palmeira e Ijuhy; no caso afirmativo, si podem ser adquiridas do governo pelo Sr. Dr. Herrmann Meyer. Antecipando-nos gratos pela solução que se dignar dar-nos temos a honra de ser" (apud NEUMANN, 2006:07).

Ao trazer o exemplo acima, espera-se que se tenha demonstrado a importância da implantação de colônias de imigrantes estabelecidos em pequenas propriedades e voltados à produção agrícola para consumo interno e, conseqüentemente, a importância das empresas de colonização particulares, bem como sua íntima ligação com o processo de ocupação territorial e privatização das terras devolutas no Rio Grande do Sul, sendo talvez a mais importante das formas de apropriação das terras, rendendo dividendos ao Estado e resolvendo os problemas de abastecimento dos centros urbanos.

Além disso, espera-se que o exemplo tenha ao menos indicado uma atuação um pouco mais zelosa do Estado sul-rio-grandense quando comparado aos demais Estados, visto que o Rio Grande do Sul, em certa medida, demarcava e regularizava suas terras devolutas, vendendo-as àqueles que se propunham a pagar por elas e expulsando aqueles que detinham ilegalmente a posse de terras.

Há, entretanto, uma única postura do governo estadual gaúcho em que pode ser vislumbrada certa liberalidade com relação a suas terras, a qual, embora isolada, não pode deixar de ser mencionada.

Em meio à realização dos trabalhos das comissões técnicas criadas em 1897 acima citadas, foram discriminadas terras públicas e privadas, verificando-se grandes áreas nas regiões de Santa Cruz, Cruz Alta e Guaporé em que, por meio de legitimação conseguida por títulos fraudulentos, a propriedade territorial do Estado havia sido ilegitimamente subtraída. Mas, em sua quase totalidade, essas terras legitimadas não mais se encontravam 
na posse dos legitimantes fraudulentos, já havendo sido adquiridas a título oneroso por colonos.

A medida governamental que se poderia considerar liberal principiou-se em 1898, com a cessão dessas terras a seus atuais ocupantes, desde que por elas fosse devidamente indenizado o governo estadual. Borges de Medeiros, então já Presidente do Estado, se justificou da medida nas seguintes palavras:

"Sob os ditames de natural eqüidade e atuado por motivos de manifesta conveniência pública, resolveu o governo ceder aos atuais ocupantes essas terras incursas em comisso, por inobservância de condições expressas e essenciais, mediante razoável indenização arbitrada de acordo com o valor relativo das posses ou prazos coloniais.

Neste sentido, foram expedidas instruções adequadas para que os pagamentos se realizem da mesma forma por que se efetua a cobrança da dívida colonial. Assim procedendo, teve em vista o Governo não agravar a situação dos pequenos agruicultores que detêm hoje as ditas terras, por compras feitas em boa fé a particulares ou associações que exploravam no extinto regime esse bens de domínio do Estado, recorrendo a artificiosos processos em satisfação de insaciáveis interesses egoísticos" (apud OSÓRIO, 1982:136).

Mais adiante, com um decreto datado de 10 de fevereiro de 1903, embora fossem anuladas as sentenças de legitimação, os colonos foram isentados do pagamento de quaisquer indenizações. Em 20 de setembro de 1906, o mesmo Borges de Medeiros, em sua Mensagem à Assembléia dos Representantes, justificará essa postura governamental nos seguintes termos:

"Dominado pelo mesmo sentimento de equanimidade e invariável ação tutelar dos interesses coloniais, não duvidei ampliar aquele 
ato [cessão de terras de 1898], expedindo o decreto de 10 de fevereiro de 1903, cujas disposições liberais isentavam os colonos nacionais ou estrangeiros do pagamento de qualquer indenização, embora anuladas as sentenças de legitimação.

(...)

Pondo termo, por essa forma, à chamada questão das terras, nenhum pretexto restará mais à celeuma mendaz que, dentro e fora do Estado, procurou desvirtuar as intenções elevadas do Governo" (Mensagem à Assembléia dos Representantes de 20 de setembro de 1906).

Como se vê, nesse ponto o governo sul-rio-grandense efetivamente agiu de forma liberal. Parece, no entanto, que mesmo aqui se tratava de situação peculiar, em que a aquisição fraudulenta da legitimação da posse deveria ser ponderada com a boa-fé do terceiro adquirente a título oneroso, justificando, ao menos em certa medida, tal liberalidade.

Dessa forma, esse único episódio não parece ser suficiente para igualar a política estadual de terras do Estado do Rio Grande do Sul à dos demais Estados, mantendo sua atuação quanto às terras devolutas um caráter de excepcionalidade pela seriedade com que a questão foi tratada. 


\section{Conclusão.}

A Lei de Terras aprovada em 1850, em virtude de diversas mudanças realizadas em seu projeto durante o debate parlamentar, acabou por receber um caráter conciliatório, de forma a compor e ajustar os interesses das classes economicamente dominantes. No entanto, na mesma medida em que tal caráter possibilitou sua aprovação, ele impossibilitou sua aplicação, uma vez que os interesses que se buscava conciliar eram, em grande parte, inconciliáveis.

Se, por um lado, para atender ao interesse dos grandes latifundiários, a lei precisava vedar o acesso à propriedade de terras aos imigrantes, garantindo que suas mãos estivessem disponíveis para o trabalho na grande lavoura, por outro lado, pretendia incentivar a imigração espontânea, atraindo imigrantes estrangeiros com a finalidade de deixar de comprometer o minguado orçamento imperial com a imigração regular, acenando aos estrangeiros com a promessa de compra de certa porção de terra.

Essa contradição foi motivo determinante para que não fosse devidamente aplicada a Lei de Terras de 1850 durante todo o regime imperial. Com isso, além da questão de terras, outras intimamente a elas vinculadas permaneceram suspensas, sem alcançar uma solução concreta durante toda a segunda metade do séc. XIX.

Dentre tais questões, destaca-se para a presente pesquisa a escassez do crédito agrícola, problema que perpassou todo o período mencionado, estando fortemente atrelado à crise de numerário decorrente da política econômica e monetária restritiva adotada pelo governo imperial a partir do início da década de 1860. Tal política se acentuou progressivamente em razão das crises financeiras de 1864 e 1875, bem como do endividamento público gerado em grande parte pela Guerra do Paraguai.

Com a crise de numerário, a oferta de crédito, em geral, encontrava-se bastante reduzida. O crédito agrícola, em especial, sofria ainda com a crescente ilegitimação do trabalho escravo, e a propriedade servil, geralmente usada como garantia dos empréstimos contraídos, deixava de ser uma garantia adequada pela sua paulatina desestabilização e desvalorização. E, por sua vez, a propriedade de terra ainda não se havia inserido definitivamente na esfera de circulação de capital, a ponto de ser considerada eficaz garantia de dívidas. O problema era também agravado pelo fato de que até então não se 
havia desenvolvido a contento uma rede bancária, ficando os empréstimos necessariamente intermediados por comissários.

O governo imperial tentou ainda resolver a situação por meio da aprovação da Lei Hipotecária de 1864 e da reforma do Banco do Brasil de 1866, dando ênfase à criação de uma carteira hipotecária do banco. Tais medidas mostraram-se, no entanto, superficiais, por não atingir a base do problema do crédito agrícola, que se encontrava na inaplicação da Lei de Terras de 1850. Sem a aplicação adequada dessa lei, o preço da terra continuaria bastante baixo, dada a facilidade com que ocorriam as apropriações de terras devolutas, além de permanecerem os títulos de propriedade de terras bastante incertos, pela ausência de um sistema registral eficiente.

Em resposta ao aumento de demanda por meio de pagamentos gerado pela abolição da escravidão, o governo imperial ainda lançaria uma derradeira tentativa de resolução do problema do crédito agrícola através da reforma bancária de 1888, aprovada durante o Gabinete de João Alfredo e efetivamente implementada no de Ouro Preto. Este último, buscando resolver a escassez do meio circulante, conferiu a um grande banco, o Banco Nacional, a atribuição de emissão de moeda e, ao lado disso, manteve uma política de socorro imediato à produção agrícola, agudamente criticada, que ficou conhecida como Auxílio à Lavoura.

Com o ocaso do Império e a instauração do regime republicano, transpareceu a fragilidade da aliança em que se firmava o movimento republicano. Com efeito, o declínio do Império deveu-se mais a seu próprio processo de deterioração do que a um projeto republicano claramente definido. Proclamada a República, essa ausência de projeto consensual daria espaço a um vácuo político, no qual setores mais progressivos da sociedade, destacadamente a classe média urbana, veriam espaço para implementar reformas liberais a tempos por eles almejadas.

É nesse contexto que surge a tentativa de reforma liberal de Rui Barbosa. Crítico contumaz da política de Auxílio à Lavoura, Rui Barbosa vê na consolidação e no alargamento do crédito hipotecário uma peça-chave de sua reforma. Inspirado na transição para o capitalismo pela via farmer, modelo de desenvolvimento agrário desenvolvido pelos países novos, de fronteiras abertas, em especial pelos Estados Unidos, Rui Barbosa pretendia inserir definitivamente a propriedade de terras na esfera de circulação de capitais, 
com a conseqüente valorização do mercado de terras e a decorrente idoneidade da propriedade imóvel como garantia hipotecária.

Rui Barbosa não ignorava que, para tanto, se fazia necessária uma profunda reforma no sistema de registro imobiliário brasileiro. E é exatamente aqui que o sistema de Registro Torrens entra como um importante elemento de sua tentativa de reforma.

De origem australiana, o sistema Torrens de registro foi instituído no Brasil por meio do decreto $\mathrm{n}^{\mathrm{o}}$ 451-B, de 31 de maio de 1890. O sistema tem como sua maior qualidade o caráter absoluto de que o título reveste a propriedade matriculada. Uma vez matriculado o imóvel, a segurança propiciada pelo Registro Torrens é tamanha que se poderia dizer que ele está garantido por um título indestrutível. Nos casos em que se constate erro no registro, o prejudicado não se deve voltar contra o proprietário intitulado, mas contra o governo, que funciona como garante do registro realizado. Para tanto, é criado um Fundo de Garantia, constituído por uma taxa equivalente a dois por mil $(0,2 \%)$ do valor da propriedade, paga à União pelo requerente do registro antes de ser feita a matrícula do imóvel. Além disso, o sistema Torrens caracteriza-se (i) pela unicidade do título que representa a propriedade imobiliária, (ii) pelo sistema de publicidade real, e não pessoal, e (iii) por consubstanciar no mesmo documento que a propriedade imobiliária todos os direitos reais que gravarem o imóvel, como a hipoteca. Como se pode notar, para os fins buscados por Rui Barbosa em seu projeto de reforma, difícil imaginar sistema registral mais apropriado que o sistema Torrens.

Ao lado da reforma registral, Rui Barbosa pretendeu instaurar uma audaciosa reforma econômica, visando, sobretudo, desafogar o país do problema crônico de escassez de meio circulante, vindo desde a década de 1860 e agravado com a abolição da escravidão. Para isso, em 17 de janeiro de 1890, à revelia dos demais integrantes do Ministério do Governo Provisório, Rui Barbosa lança um pacote de decretos que, além de reformular o crédito hipotecário e as sociedades anônimas, institui uma reforma bancária.

Tal reforma, entretanto, teve como efeito indesejado, por seus excessos emissionistas, a intensificação do ambiente especulativo que, desde a reforma bancária de 1888, esteve presente na economia brasileira. Com o excesso de dinheiro no mercado, a especulação fez com que a oferta de crédito, sempre tão difícil nas décadas antecedentes, se tornasse extremamente alta. Nesse momento, o crédito hipotecário conheceu um 
crescimento vertiginoso, e, ávidos por aproveitarem ao máximo a onda especulativa, os bancos passaram a fazer empréstimos hipotecários sem se preocuparem adequadamente com a regularidade da propriedade imobiliária que os garantia.

Interessante notar que isso ocorre exatamente quando da instauração do processo constituinte. É nesse sentido que se questiona se a temporária facilidade de crédito, notadamente o hipotecário, não teria influenciado os constituintes a colocar outros problemas à frente da regularização do sistema de registro de terras.

Com efeito, foi durante o processo constituinte que o plano de reforma registral de Rui Barbosa começou a ruir. O Governo Provisório apresentou um projeto de Constituição, elaborado pela Comissão dos Cinco e revisto pelos ministros, especialmente por Rui Barbosa, no qual uma clara visão unionista era defendida, o que gerou muita discussão, pois, em muitos pontos, tal projeto contrapunha-se aos interesses federalistas extremados das oligarquias estaduais. Dentre esses pontos, estava a previsão de que a propriedade das terras devolutas seria da União. Após longos debates e muitas propostas de emendas apresentadas, acabou sendo aprovada uma emenda reformando o projeto do Governo Provisório para dispor que "pertencem aos Estados as minas e terras devolutas situadas nos seus respectivos territórios, cabendo à União somente a porção do território que for indispensável para a defesa das fronteiras, fortificações, construções militares e estradas de ferro federais".

Foi uma grande derrota imposta ao projeto de reforma de Rui Barbosa. Com isso, restava formalmente comprometida a instituição do Registro Torrens pelo Governo Provisório, ao raciocínio de que, se as terras devolutas pertenciam aos Estados federados, era a eles que cabia dispor sobre seu registro e sua demarcação. Nesse sentido foi a decisão do STF de agosto de 1895.

Assim, após a promulgação da Constituição de 1891, passou aos Estados a atribuição de cuidar das terras devolutas em seus territórios. E eles a exerceram muito mal! Procurando, por um lado, inibir algumas novas posses, como as dos imigrantes subsidiados e dos escravos libertos, e, por outro, legitimar as posses ilegalmente contraídas por grandes posseiros de terras, os Estados reaproveitaram como arcabouço jurídico a Lei de Terras de 1850. E ainda o fizeram de maneira distorcida, prorrogando sucessiva e freqüentemente a 
data-limite das posses legitimáveis, incorrendo em uma política de liberalidades que aproveitaria a poucos privilegiados. 


\section{Bibliografia.}

a) Arquivos e Documentos Oficiais

BRASIL. Ministério da Fazenda. (1889) Auxílios à Lavoura, Rio de Janeiro: Imprensa Nacional.

. (1883) Proposta e Relatório apresentado à Assembléia Geral Legislativa na segunda sessão da décima sétima legislatura pelo Ministro e Secretário de Estado dos Negócios da Fazenda - Visconde de Paranaguá, Rio de Janeiro: Imprensa Nacional.

. (1884) Proposta e Relatório apresentado à Assembléia Geral Legislativa na segunda sessão da décima sétima legislatura pelo Ministro e Secretário de Estado dos Negócios da Fazenda - Lafayette Rodrigues Pereira, Rio de Janeiro: Imprensa Nacional.

. (1885) Proposta e Relatório apresentado à Assembléia Geral Legislativa na segunda sessão da décima sétima legislatura pelo Ministro e Secretário de Estado dos Negócios da Fazenda - José Antonio Saraiva, Rio de Janeiro: Imprensa Nacional.

. (1886) Proposta e Relatório apresentado à Assembléia Geral Legislativa na segunda sessão da décima sétima legislatura pelo Ministro e Secretário de Estado dos Negócios da Fazenda - F. Belisário Soares de Sousa, Rio de Janeiro: Imprensa Nacional.

. (1887) Proposta e Relatório apresentado à Assembléia Geral Legislativa na segunda sessão da décima sétima legislatura pelo Ministro e Secretário de Estado dos Negócios da Fazenda - F. Belisário Soares de Sousa, Rio de Janeiro: Imprensa Nacional.

. (1888) Proposta e Relatório apresentado à Assembléia Geral Legislativa na segunda sessão da décima sétima legislatura pelo Ministro e Secretário de Estado dos Negócios da Fazenda - João Alfredo Côrrea de Oliveira, Rio de Janeiro: Imprensa Nacional. 
. (1889) Proposta e Relatório apresentado à Assembléia Geral Legislativa na segunda sessão da décima sétima legislatura pelo Ministro e Secretário de Estado dos Negócios da Fazenda - João Alfredo Côrrea de Oliveira, Rio de Janeiro: Imprensa Nacional.

. (1891) Proposta e Relatório apresentado à Assembléia Geral Legislativa na segunda sessão da décima sétima legislatura pelo Ministro e Secretário de Estado dos Negócios da Fazenda - Rui Barbosa, Rio de Janeiro: Imprensa Nacional.

b) Livros e Artigos

AFONSO CELSO, Conde de. (1935) Visconde de Ouro Preto (Excerptos Biográphicos), Porto Alegre: Livraria do Globo.

ALMEIDA, Pedro F. C. (1992) "A gestação das condições materiais da implantação da indústria gaúcha - 1870-1930”. In: Ensaios FEE. Porto Alegre, vol. 13, nº 2.

ANDRADA, Antonio Carlos Ribeiro de. (1923) Bancos de Emissão no Brasil, Rio de Janeiro: Leite Ribeiro.

AREND, Marcelo. (2004) Desenvolvimento e Desequilibrio Industrial no Rio Grande do Sul: uma análise institucionalista e neo-schumpeteriana evolucionista. UFSC. Florianópolis. (Dissertação de Mestrado).

ARRAES, Raimundo M. (1981) O Rio Grande do Sul e suas Instituições Governamentais. Brasília: Editora Universidade de Brasília.

AXT, Gunter. (2001a) “O Poder Judiciário na sociedade coronelista gaúcha (1889-1930)”. In: Revista da Ajuris, Porto Alegre, no 82, Vol. 1, págs 319 a 349. 
. (2001b) Gênese do Estado Burocrático-Burguês no Rio Grande do Sul (1889 - 1929). Tese de Doutorado. São Paulo: USP.

. (2002a) "Contribuição ao debate historiográfico concernente ao nexo entre estado e sociedade para o Rio Grande do Sul castilhista-borgista". In: Revista Métis História \& Cultura, Caxias do Sul: Editora da Universidade de Caxias do Sul, $\mathrm{n}^{\mathrm{o}} 1$.

. (2002b) “Constitucionalidade em Debate: A Polêmica Carta Estadual de 1891". In: Revista Justiça \& História - Memorial do Judiciário do Rio Grande do Sul. Porto Alegre: Tribunal de Justiça do Estado do Rio Grande do Sul - Departamento de Artes Gráficas, vol. 2, nº. 3.

BAK, Joan L. (1977) Some antecedents of corporatism: state economic intervention and rural organization in Brazil - the case of Rio Grande do Sul, 1890-1937. New Haven: Yale University.

BARBOSA, Rui. (1892) Finanças e Política na República, discursos e escriptos, Rio de Janeiro: Companhia Impressora.

. (1875) Obras Completas de Ruy Barbosa, Rio de Janeiro: Fundação Casa de Rui Babrbosa.

BARETTA, S.D. (1985) Political Violence and Regime Change: A Study of the 1893 Civil War in Southern Brazil, tese de PhD, Pittsburgh: Universidade de Pittsburgh,.

BEIGUELMAN, Paula. (1968) A formação do povo no complexo cafeeiro, aspectos políticos. São Paulo: Pioneira.

BELLO J. M. (1964) História da República: 1889-1954. São Paulo: Companhia Editora Nacional. 
BERNARDES, Nilo. (1950) "Bases geográficas do povoamento do Estado do Rio Grande do Sul". In: Boletim Geográfico, Porto Alegre, n. ${ }^{\circ}$ 171, nov./dez.

BERNARDY, R. J., DALOTTO, R. A. S., LOCH, C. (1999) "Evolução da Estrutura fundiária rural: o Caso da Região Sul do Brasil e do Sul da Mesopotâmia Argentina". In: Revista Geodésia, nº 3.

Disponível em: http://geodesia.ufsc.br/Geodesia-online/arquivo/1999/03/RR.htm

BOEIRA, Nelson e outros. (1980) RS: Cultura \& Ideologia. Porto Alegre: Editora Mercado Aberto.

BONAVIDES, Paulo e ANDRADE, Paes de. (1991) História Constitucional do Brasil, $3^{\mathrm{a}}$ ed., Rio de Janeiro: Paz e Terra.

BORGES, João Afonso. (1960) O Registro Torrens no Direito Brasileiro: doutrina, jurisprudência, legislação e formulários. Rio de Janeiro: Saraiva.

BOTELHO JR., Cid de Oliva. (2002) Instabilidade Financeira na Primeira Década Republicana, Campinas: UNICAMP.

CALÓGERAS, João Pandiá. (1960) A Politica Monetária do Brasil, São Paulo: Cia. Editora Nacional.

CAMPANTE, Rubens Goyatá. (2003) "Patrimonialismo em Faoro e Weber e a Sociologia Brasileira”. In: Revista Dados, Rio de Janeiro, vol. 46, nº 1.

CANO, Wilson. (1990) Raízes da concentração industrial em São Paulo. $3^{\mathrm{a}}$ ed. São Paulo: Hucitec.

CARVALHO, Afrânio de. (1977) "Registro Torrens", In: Revista do Instituto de Registro Imobiliário do Brasil, São Paulo, vol. 3, pg. 26. 
CARVALHO, Maria Lúcia Leitão e PEREIRA, Paulo Roberto Dias. (1995) "Rio Grande do Sul e São Paulo: o papel das políticas orçamentárias na promoção do desenvolvimento econômico estadual na Primeira República (1889-1930)”. In: Ensaios FEE, Porto Alegre, v. 16, n. 2 , p. $729-787$.

- (1996) "A política fiscal dos Estados e as funções de acumulação e de legitimação". In: Gaúchos e Paulistas: dez escritos de história regional comparada. (TARGA, Luiz R. P., org.), Porto Alegre: FEE.

. (1999) “O federalismo fiscal na Primeira República (1889-1930)”. In: II

Colóquio sobre federalismo fiscal, ajuste fiscal, reformas de Estado e transformações recentes no Ceará. Fortaleza: UFC.

CARVAlHO, José Murilo de. (1981) Modernização Frustrada: a Política de Terras no Império. Revista Brasileira de História, 1, 39-57.

. (1988) Teatro de sombras: a política imperial. São Paulo: Vértice.

COBRA, Amador Nogueira. (1923) Em um Recanto do Sertão Paulista. São Paulo: Tipografia Hennies Irmãos.

COSTA, João Cruz. (1956) O Positivismo na República, São Paulo:Editora Nacional.

COSTA, Wilma Peres. (1996) A espada de Dâmocles - O exército, a Guerra do Paraguai e a crise do Império. São Paulo: Hucitec/UNICAMP.

. (1998) A Questão Fiscal Na Transformação Republicana: Continuidades e Descontinuidades. Economia e Sociedade, Campinas, v. 10, p. 141-174,. 
DA COSTA, E. V. (1977) Da Monarquia à Republica: momentos decisivos. São Paulo: Ciências Humanas.

DALMAZO, Renato. (2003) As relações de comércio do Rio Grande do Sul - do século XIX a 1930. Porto Alegre: FEE.

DEAN, W. (1977) Rio Claro: um sistema brasileiro de grande lavoura: 1820-1920, Rio de Janeiro: Paz e Terra.

DIDONET, Zilah (1977) O positivismo e a constituição Riograndense de 14 de julho de 1891. Santa Maria: UFSM.

DINIZ, Maria Helena. (1992) Sistema de registros de imóveis. São Paulo: Saraiva.

FAORO, Raymundo. (1993) A Aventura Liberal numa Ordem Patrimonialista. In: Revista $U S P, \mathrm{n}^{\circ} 17$, pg. 14-29. . (1998) Os Donos do Poder - Formação do Patronato Político Brasileiro. $13^{\mathrm{a}}$ ed. São Paulo: Globo.

FÉLIX, Loiva Otero. (1987) Coronelismo, borgismo e cooptação política. Porto Alegre: Editora da Universidade/RS.

FERNANDES, Florestan. (1987) A revolução burguesa no Brasil: ensaio de interpretação sociológica. Rio de Janeiro: Guanabara.

FONSECA, Pedro C. D. (1983) RS: economia \& conflitos políticos na República Velha. Porto Alegre: Mercado Aberto.

. (1985) "A transição capitalista no Rio Grande do Sul: a economia gaúcha na Primeira República”. In: Estudos Econômicos, São Paulo, vol. 15, nº. 2, p. 263-289, mai/ago. 
. (1993) "Revolução Federalista: interpretação" In: Pensar a Revolução

Federalista.(ALVES, F. N. et al., org.). Rio Grande: Universidade do Rio Grande.

FRAGALE FILHO, Roberto da S. (1998) A Aventura Política Positivista: um projeto Republicano de Tutela. São Paulo: LTR.

FREITAS, Décio. (1980) O Capitalismo Pastoril. Porto Alegre: EST/UCS.

FRANCO, Gustavo Henrique Barroso. (1987) Reforma Monetária e Instabilidade durante a Transição Republicana, Rio de Janeiro: BNDES.

FRANCO, M. S. C. (1983) Homens Livres na Ordem Escravocrata. São Paulo: Kairós.

FRANCO, S. C. (1988) Júlio de Castilhos e sua época. Porto Alegre: Editora da UFRGS. . (1993a) A guerra civil de 1893. Porto Alegre: Editora da UFRGS.

FUNDAÇÃO DE ECONOMIA ESTATÍSTICA - FEE. (1981). De Província de São Pedro a Estado do Rio Grande do Sul - censos do RS 1803 - 1950. Porto Alegre: FEE.

GOMES, Ângela de Castro e FERREIRA, Marieta de Moraes. (1989) Primeira República: um balanço historiográfico. Revista Estudos Históricos, Rio de Janeiro, vol. 2, n. 4, p. 244280.

GOULART, Jorge S. (1978). A Formação do Rio Grande do Sul. Porto Alegre: Martins Livreiro Editor.

GRANZIEIRA, Rui Guilherme. (1979) A Guerra do Paraguai e o Capitalismo no Brasil, Moeda e Vida Urbana na Economia Brasileira, São Paulo: Hucitec/UNICAMP. 
GUIMARÃES, Alberto Passos. (1977) Quatro Séculos de Latifúndio. Rio de Janeiro: Paz e Terra.

HERRLEIN JR., Ronaldo e DIAS, Adriana. (1993) “Trabalho e indústria na Primeira República: um ensaio de análise comparativa entre as sociedades do Rio Grande do Sul e de São Paulo”. In: Ensaios FEE, Porto Alegre, v. 14, n. 1, p. 255-298.

HERRLEIN JR., Ronaldo. (2000) Rio Grande do Sul, 1889-1930: um outro capitalismo no Brasil meridional? Tese de doutoramento pelo Instituto de Economia da UNICAMP. . (2004) "A transição capitalista no Rio Grande do Sul, 1889-1930: uma nova interpretação". In: Revista Economia e Sociedade, Campinas, vol. 13, nº 1 (22), pg. 175-207, jan./jun..

HOLLOWAY, Thomas H. (1984) Imigrantes para o café: café e sociedade em São Paulo, 1886-1934. Rio de Janeiro: Paz e Terra.

HOLSTON, James (1993) "Legalizando o ilegal: propriedade e usurpação no Brasil". In: Revista Brasileira de Ciências Sociais. n²1, pg. 68-89.

KÁTIA, Cristina Petri. (2005) “Terras e Imigração em São Paulo: Política Fundiária e Trabalho Rural”. In: Histórica - Revista Eletrônica do Arquivo do Estado de São Paulo, São Paulo, no 2 .

KLIEMANN, Luiza H. Schmitz. (1986) RS: terra e poder: história da questão agrária. Porto Alegre: Mercado Aberto.

LAMOUNIER, Bolivar. (1978) Formação de um pensamento político autoritário na primeira república. Uma interpretação. In: História geral da civilização brasileira. (FAUSTO, Boris et al., org.) Rio de Janeiro: Difel,. v. 2, t. 3, pg. 343-374. 
LAGEMANN, Eugênio. (1978). A Industrialização no Rio Grande do Sul: um estudo histórico. In: Projeto Pequena e Média Empresa no RS. Porto Alegre:UFRGS.

. (1980) Imigração e industrialização. In: Rio Grande do Sul: imigração e colonização. (DACANAL, J. H. et al., org.), Porto Alegre: Mercado Aberto.

. (1999) "A história do Sistema Financeiro no Rio Grande do Sul e no Uruguai dos primórdios até 1931: uma comparação". In: Segundas Jornadas de Historia Económica, Montevideo.

LEITE, Fábio de Carvalho. (2003) 1891: A Construção da Matriz Político-Institucional da República no Brasil, Dissertação de Mestrado. Rio de Janeiro: PUC-RJ.

LEAL, Victor Nunes. (1997) Coronelismo, enxada e voto: o município e o regime representativo no Brasil. $3^{\text {a }}$ ed., Rio de Janeiro: Editora Nova Fronteira.

LÊNIN, Vladimir. (1982) O desenvolvimento do capitalismo na Rússia . São Paulo: Abril.

LEVINE, Robert. (1977) "O Rio Grande do Sul como fator de instabilidade na República Velha". In: História geral da civilização brasileira. (FAUSTO, Boris et al., org.) Rio de Janeiro: Difel,. v. 2, t. 3.

LEVY, Maria Bárbara. (1977) História da Bolsa de Valores do Rio de Janeiro, Rio de Janeiro: IBMEC.

- (1995) A Indústria do Rio de Janeiro através de suas sociedades anônimas (esboços de história empresarial). Rio de Janeiro: Sec. Municipal de Cultura/EDUFRJ.

LIEDKE FILHO, E. (1972a) Notas introdutórias ao estudo do movimento republicano e positivismo no Rio Grande do Sul. Porto Alegre: UFRGS. 
. (1972b) Imposto de Exportação e Imposto Territorial: nota sobre as relações entre o Estado e a economia sob a hegemonia do Partido Republicano Riograndense. Porto Alegre: UFRGS.

. (1973) Despesas estaduais sul-rio-grandenses. Brasília: UNB.

LIMA, Ruy Cirne. (1954) Pequena história territorial do Brasil (sesmarias e terras devolutas). $2^{\mathrm{a}}$ ed. Porto Alegre: Livraria Sulina.

LINHARES, Maria Yedda \& SILVA, Francisco Carlos Teixeira da. (1981) História da agricultura brasileira: combates e controvérsias. São Paulo: Brasiliense.

. (1999) Terra prometida. Uma história da questão agrária no Brasil.

Rio de Janeiro: Campus.

LINS, Ivan. (1967) História do Positivismo no Brasil. 2. ed. São Paulo: Companhia Editora Nacional.

LOVE, J. (1975) O regionalismo gaúcho e as origens da Revolução de 1930. São Paulo: Perspectiva.

. (1982) A Locomotiva, São Paulo na Federação Brasileira - 1889 - 1937.

Rio de Janeiro: Paz e Terra.

. (1993) "Reflections on the revolution of 1893". In: Pensar a Revolução Federalista.(ALVES, F. N. et al., org.). Rio Grande: Universidade do Rio Grande.

LUZ, Nícia Vilela. (1960) A luta pela industrialização do Brasil. São Paulo: Alfa Ômega. 
MAIA COSTA, L. A. (2003) O ideário urbano paulista na virada do século: o engenheiro Theodoro Sampaio e as questões territoriais e urbanas modernas (1886-1903). São Paulo: Fapesp.

MARCONDES, Renato Leite. (2002) "O financiamento hipotecário da cafeicultura no Vale do Paraíba paulista (1865-87)". In: Revista Brasileira de Economia, Rio de Janeiro, vol. 56, $\mathrm{n}^{\mathrm{o}} 1$.

MARCONDES, Renato Leite e MADURO JÚNIOR, Paulo Rogério Rodrigues, (2005). Crédito Hipotecário em São Paulo: evidências para um núcleo urbano em expansão (1865-1890). Encontro Nacional de Economia: $33^{\circ}$ Encontro Nacional de Economia, $33^{\circ}$.

MARQUES, Alvarino F. (1990) Evolução das Charqueadas Rio-Grandenses. Porto Alegre: Martins Livreiro.

MARTINS, José Souza. (1980) Expropriação e Violência (a questão política no campo). São Paulo: Hucitec.

. (1986) O Cativeiro da Terra. 3. ed. São Paulo: Ciências Humanas.

MAYRINK LESSA, Francisco de Paula. (1975) Vida e Obra do Conselheiro Mayrink (completada por uma genealogia da família), Rio de Janeiro: Pongetti.

MEDEIROS, Laudelino T. (1975) Formação da Sociedade Rio-Grandense. Porto Alegre: UFRGS.

MELLO, Pedro Carvalho de. (1984) A economia da escravidão nas fazendas de café: 1850-1888. Rio de Janeiro: PNPE.

MILLIET. Sérgio. (1982) Roteiro do café e outros ensaios. São Paulo: Hucitec. 
MINELLA, Ary César. (1985) "Reforma Tributária: a implantação do imposto territorial no

Rio Grande do Sul na Primeira República". In: 150 anos de finanças públicas (LAGEMANN, Eugenio, org.).. Porto Alegre: FEE, pg. 310.

MIRANDA, M.. (1998) Rio Grande do Sul: tributação e economia. Dissertação de Mestrado. Porto Alegre: UFRGS.

MONBEIG, Pierre.(1984) Pioneiros e Fazendeiros de São Paulo. São Paulo: Hucitec.

MONTEIRO, Denise Mattos. (2002) "Política de terras no Brasil: elite agrária e reações à legislação fundiária na passagem do Império para a República". In: Revista História Econômica \& História das Empresas. vol. 5, nº 2.

MOORE JR., B. (1983) As origens sociais da ditadura e da democracia: senhores e camponeses na construção do mundo moderno, São Paulo: Martins Fontes.

MOTTA, Márcia Maria Menendes. (1998) Nas Fronteiras do Poder. Conflito e Direito à Terra no Brasil do século XIX. Rio de Janeiro: Arquivo Público do Estado do Rio de Janeiro.

. (2002) "Continuidade nas Rupturas: Legislação Agrária e Trabalhadores Rurais no Início da República". In: Revista Brasileira de Pós-Graduação em Ciências Sociais, Brasília, vol. 6, pg. 127-147.

MUELLER, Bernado. (2005) Evolução Histórica dos Direitos de Propriedade sobre Terras no Brasil e EUA, Universidade de Brasília, junho.

MÜLlER, Carlos Alves. (1998) A história econômica do Rio Grande do Sul, Porto Alegre: Banrisul. 
NEUMANN, Rosane Márcia. (2006) "A colonização do Planalto gaúcho por empresas privadas". In Revista Histórica do Arquivo Público do Estado de São Paulo, n ${ }^{\circ}$ 17, dezembro.

NORA, Nilse Cortese Dalla. (2002) Quem Chega, Quem Sai a Política de Distribuição de Terras em Jaboticabal - RS. Passo Fundo: Universidade de Passo Fundo (Dissertação de Mestrado).

OLKOSKI, W. (2002) História agrária do Médio Alto Uruguai - RS: colonização, (re)apossamento das terras e exclusão (1900-1970), São Leopoldo: UNISINOS. (Dissertação de Mestrado).

OSÓRIO, Joaquim Luis. (1982) Constituição política do Estado do Rio Grande do Sul: Comentário. Brasília: UNB.

OURO PRETO, Visconde de. (1899). "Finanças" In: A Década Republicana (OURO PRETO, Visconde de et al.), Rio de Janeiro: Cia Typographica do Brasil.

PELÁEZ, Carlos Manuel e SUZIGAN, Wilson. (1981) História monetária do Brasil: análise da política, comportamento e instituições monetárias. $2^{\mathrm{a}}$ ed. Brasília: Ed. da Universidade de Brasília.

PEREIRA, Paulo R. D. (1996) "As políticas de gasto público dos Estados e a promoção do desenvolvimento". In: Gaúchos e Paulistas: dez escritos de história regional comparada. (TARGA, Luiz R. P., org.), Porto Alegre: FEE.

PERISSINOTTO, Renato Monseff. (2000) Estado e Capital Cafeeiro em São Paulo (18891930). São Paulo: FAPESP; Campinas: UNICAMP. . (2001) "Estado, capital cafeeiro e política tributária na economia paulista exportadora, 1889-1930”, In: Latin American Research Review, vol. 36, n 1, pp. 151-169. 
PESAVENTO, Sandra J. (1979) "República velha gaúcha: Estado autoritário e economia". In: RS, Economia e Política (DACANAL, José et al., org.), Porto Alegre, Mercado Aberto.

. (1980) República Velha Gaúcha: charqueadas, frigorificos, criadores. Porto Alegre: Movimento.

. (1980) República Velha Gaúcha, Porto Alegre: Editora Movimento.

. (1985) História da Indústria Sul-rio-grandense. Guaíba: Riocell.

. (1988) A Burguesia Gaúcha: dominação do capital e disciplina do trabalho. Porto Alegre: Mercado Aberto.

. "A invenção da sociedade gaúcha". In: Ensaios FEE. Porto Alegre: FEE, n. ${ }^{\circ}$ 2, 1993.

PETRONE, Pasquale. (1961) "Notas sobre os sistemas de culturas na Baixada do Ribeira SP”. In: Boletim Paulista de Geografia. São Paulo, (39),47-63.

PINTO, Celi R. J. (1986) Positivismo: um projeto político alternativo (Rio Grande do Sul: 1889-1930). Porto Alegre: L\&PM,.

PIÑEIRO, Théo Lobarinhas. (1996) Política e Crédito Agrícola no Brasil do Século XIX, América Latina en la Historia Econômica, nº 6, julio-diciembre.

PRADO, Luiz Carlos Delorme. (2003) A Economia Política das Reformas Econômicas da Primeira Década Republicana. Revista Análise Econômica da Faculdade de Ciências Econômicas da UFRGS, Edição nº 39, Ano 21, Março de 2003.

PRADO JÚNIOR, Caio (1966). A Revolução Brasileira. São Paulo: Brasiliense. 
. (1972) Formação do Brasil Contemporâneo. $12^{\mathrm{a}}$ ed. São Paulo:

Brasiliense.

. (1977) História Econômica do Brasil. 20. ed. São Paulo: Brasiliense.

REIS, Elisa M. P. (1982) "Elites Agrárias, State-Building e Autoritarismo". In: Revista Dados, vol. 25, nº 3, pp. 331-348.

ROCHE, Jean. (1969) A Colonização Alemã e o Rio Grande do Sul. Porto Alegre: Globo,.

RODRIGUES, Luiz C. B. (1999) “O modelo de implantação da República burguesa no Rio Grande do Sul". In: Rio Grande do Sul: quatro séculos de história (QUEVEDO, Júlio), Porto Alegre: Martins Livreiro.

RODRIGUEZ, Ricardo Vélez. (2000) Castilhismo: uma filosofia da república. Brasília: Senado Federal, Conselho Editorial.

ROURE, Agenor de. (1920) A Constituinte Republicana. Rio de Janeiro: Imprensa Nacional, vol. 1 e 2.

SAES, Flávio Azevedo Marques de. (1981) As ferrovias de São Paulo, 1870-1940. São Paulo: Hucitec.

SAES, Décio. (1985) A Formação do Estado burguês no Brasil (1888-1891), Rio de Janeiro: Paz e Terra.

. (2000) "Prefácio". In: Estado e Capital Cafeeiro em São Paulo (18891930). (PERISSINOTTO, R. M.). São Paulo: FAPESP.

SCHULZ, J. (1997) A crise financeira da abolição. São Paulo: EDUSP. 
SILVA, Ligia Osório. (1990) A Lei da Terra - Um Estudo sobre a História da Propriedade da Terra no Brasil. São Paulo: PUC-SP (Tese de Doutorado).

.(2002) “A Apropriação Territorial na Primeira República”. In: História Econômica da Primeira República. (SILVA, Sérgio S. et al., org.). $2^{\mathrm{a}}$ ed. São Paulo: Hucitec, p. 166.

SIMÃO, André Luciano. (2001) Congressos Agrícolas de 1878: um retrato do reformismo ao final do século XIX. Campinas, Dissertação (Mestrado em Sociologia) - Instituto de Filosofia e Ciências Humanas, Unicamp.

SMRECSÁNYI, Tamás. (1990) Pequena história da agricultura brasileira. São Paulo: Contexto.

SOARES, Sebastião F. (1865) Esboço ou primeiros traços da crise commercial da cidade do Rio de Janeiro em 10 de setembro de 1864. Rio de Janeiro: Laemmert.

SODRÉ, N. W. (1976) História da Burguesia Brasileira. 10a ed. Rio de Janeiro: Civilização Brasileira.

SOUZA, Carlos Inglês de. (1924) A anarchia monetária e suas conseqüências. São Paulo: Companhia Graphico-Editora Monteiro Lobato.

. (1979) Formação Histórica do Brasil. $10^{\mathrm{a}}$ ed. Rio de Janeiro:

Civilização Brasileira.

SOUZA, Eduardo Pacheco Ribeiro de. (2007) Os serviços notariais e registrais no Brasil. Jus Navigandi, Teresina, ano 11, n. 1358.

SPONCHIADO, Breno Antonio. (2000) O Positivismo e a Colonização do Norte do Rio Grande do Sul. PUC-RS (Dissertação de Mestrado) Porto Alegre. 
STREIT, Isléia Rossler. (2003) Coronéis e Imigrantes: das Lutas pelo Poder à Conquista do espaço. Saldanha Marinho. 1899 a 1930. (Dissertação de Mestrado), Passo Fundo: Universidade de Passo Fundo.

STROHAECKER, Tânia Marques. (2005) "Atuação Do Público e do Privado na Estruturação do Mercado de Terras de Porto Alegre (1890-1950)". In: Scripta Nova Revista Electrónica de Geografía y Ciencias Sociales. Barcelona: Universidad de Barcelona, Vol. 9, nº 194.

SWEIGART, Joseph Earl. (1980) Financing and marketing Brazilian export agriculture: the coffee factors of Rio de Janeiro, 1850-1888. (Tese de Doutorado) University of Texas.

TANNURI, Luiz A. (1981) O encilhamento. São Paulo: Hucitec/Funcamp.

TARGA, Luiz Roberto P. e SILVA, Edmilson Nunes S. (2000) "A exclusão política da oligarquia tradicional gaúcha”. In: Primeiras Jornadas de História Regional Comparada.

TARGA, Luiz Roberto P. (1996a) "O Rio Grande do Sul: fronteira entre duas formações históricas". In: Gaúchos e Paulistas: dez escritos de história regional comparada. (TARGA, Luiz R. P., org.), Porto Alegre: FEE.

. (1996b) "As diferenças entre o escravismo gaúcho e o das plantations do Brasil". In: Gaúchos e Paulistas: dez escritos de história regional comparada. (TARGA, Luiz R. P., org.), Porto Alegre: FEE..

. (1996c) "Violência revolucionária e fundação do Estado burguês" In:

Gaúchos e Paulistas: dez escritos de história regional comparada. (TARGA, Luiz R. P., org.), Porto Alegre: FEE. 
. (1998) "Elites regionais e formas de dominação". In: Breve Inventário de Temas do Sul. (TARGA, Luiz R. P., org.), Lajeado: Univates.

. (2003) "A fundação do estado burguês no Rio Grande do Sul (18911913)". In: V Congresso de História Econômica da ABPHE.

WASSERMAN, Claudia. (2004) O Rio Grande do Sul e as elites gaúchas na Primeira República: guerra civil e crise no bloco do poder. In: Capítulos de História do Rio Grande do Sul (GRIJÓ, Luiz Alberto et al., org.), Porto Alegre: Editora da UFRGS, pg. 398.

ZANATTA, O. (1984) “A titulação de terra rural no Brasil”. In: Simpósio Internacional de Experiência Fundiária. Salvador: INCRA, pg. 39. 